THE US ARMY WAR COLLEGE

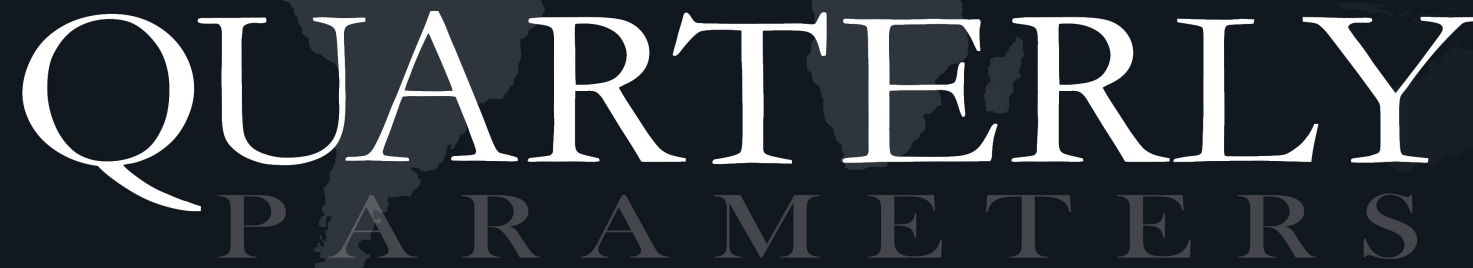

Contemporary Strategy \& Landpower

\title{
American Power in Transition
}

Isaiah Wilson

James E. Goodby and Ken Weisbrode

Anna Simons

Fighting Irregular Fighters

Sibylle Scheipers

Robert J. Bunker

Robert L. Feldman and Michel Ben Arrous

Conflict by Other Means

David J. Katz

Juan C. Zarate

Douglas W. Winton

Preparing for Netwars Frank J. Cilluffo and Joseph R. Clark

Special Commentary: The QDR and Landpower

Francis G. Hoffman 


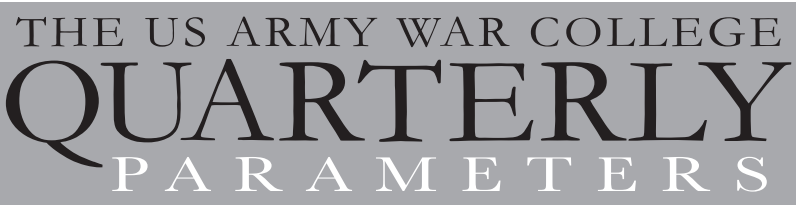

Secretary of the Army

Honorable John M. McHugh

\section{Chief of Staff of the Army}

General Raymond T. Odierno

\section{Commandant}

Major General Anthony A. Cucolo III

\section{Editor}

Dr. Antulio J. Echevarria II

\section{Managing Editor}

Mrs. Ruth A. Mueller

\section{Editorial Assistant}

Mrs. Tammy C. Miesner

\section{Editorial Board Members}

Colonel Murray R. Clark, USAF

Norwich University

Dr. Martin L. Cook

US Naval War College

Dr. Conrad C. Crane, LTC (USA Retired)

Military History Institute

Mark J. Eshelman, COL (USA Retired)

Department of Distance Education

Dr. Paul Rexton Kan

Department of National Security and Strategy

James O. Kievit, LTC (USA Retired)

At Large

Dr. Janeen M. Klinger

Department of National Security and Strategy

Dr. George E. Reed, COL (USA Retired)

University of San Diego

Dr. Andrew C. Scobell

RAND Corporation

John F. Troxell, COL (USA Retired)

Strategic Studies Institute

Dr. Marybeth P. Ulrich

Department of National Security and Strategy

\section{Emeritus}

Leonard J. Fullenkamp, COL (USA Retired) (GPO) at bookstore.gpo.gov.
US Army War College Quarterly

Parameters

47 Ashburn Drive | Carlisle PA 17013-5010

717.245 .4943

strategicstudiesinstitute.army.mil/pubs/parameters usarmy.carlisle.awc.mbx.parameters@mail.mil

The US Army War College Quarterly, Parameters, is a refereed forum for contemporary strategy and landpower issues. It furthers the education and professional development of senior military officers, and members of government and academia concerned with national security affairs.

Subscriptions: US Army War College graduates who are actively employed by the government as well as select organizations may receive a gratis subscription. For eligibility requirements, visit strategicstudiesinstitute. army.mil/pubs/parameters.

Non-graduates, retired graduates, and the general public may subscribe through the Government Printing Office

Address Changes: Submit address changes for unpaid subscriptions to the Parameters office by e-mail or phone.

For paid subscriptions, submit address changes to the GPO (bookstore.gpo.gov).

Reprint Requests: For permission to reprint articles, contact the Parameters editorial office by phone or e-mail. Be prepared to provide the article's title, author's name, publication data, intended use, quantity, and means of distribution.

Commentaries \& Replies: We invite reader commentaries on articles appearing in Parameters. Not all commentaries can be published. For those that are, the author of the article will be invited to provide a reply. For additional information, visit strategicstudiesinstitute. army.mil/pubs/parameters.

\footnotetext{
Parameters is an official US Army Periodical, published quarterly by the US Army War College. The Secretary of the Army has determined that publication of this periodical is necessary in the transaction of the public business as required by law of the Department. Use of funds for printing this publication has been approved by the Secretary of the Army in accordance with Army regulations.

Parameters is indexed in, inter alia, Air University Library Index to Military Periodicals, U.S. Government Periodicals Index, LexisNexis Government Periodicals Index, Worldwide Political Science Abstracts, Lancaster Index to Defence \& International Security Literature (UK), and PAIS Bulletin. Book reviews are indexed in Gale Group's Book Reviem Index. Parameters is also available through ProQuest and on microfilm and microfiche from UMI.

Periodicals postage is paid at Carlisle, Pennsylvania, and additional entry offices.

ISSN 0031-1723 | USPS 413530 | Library of Congress Catalog Card No. 70-612062.
} 


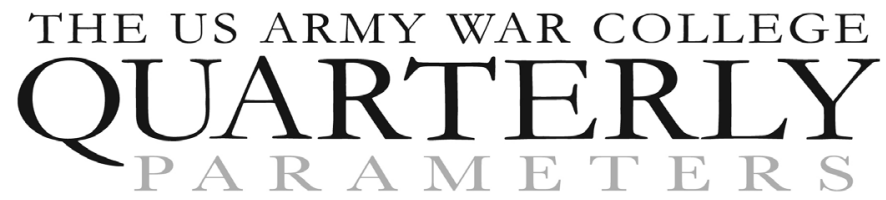

Vol. 43 No. 4 • Winter 2013-14

\section{Features}

Special Commentary

7 What the QDR Ought to Say about Landpower

Francis G. Hoffman

American Power in Transition

15 The True Tragedy of American Power

Isaiah Wilson

Confusing Force with Power

35 Rebalancing US Military Power

Anna Simons

Changing How We Advise \& Partner
27 Redirecting US Diplomacy

James E. Goodby and

Ken Weisbrode

Thinking Globally, Acting Regionally

Fighting Irregular Fighters

45 Is the Law of Armed

Conflict Outdated?

Sibylle Scheipers

Delegitimizing Irregular Fighters

67 Confronting Africa's Sobels

Robert L. Feldman and

Michel Ben Arrous

Soldiers by Day, Rebels by Night
57 Defeating Violent Nonstate Actors

Robert J. Bunker

Optimizing Landpower's Role

Conflict by Other Means

77 Waging Financial War

David J. Katz

Coercing Friends \& Enemies
87 The Coming Financial Wars

Juan Zarate

Retaining the US Advantage

99 Economic Statecraft: China in Africa

Douglas W. Winton

Leveraging Economic Growth

\section{Preparing for Netwars}

\section{Repurposing Cyber Command}

Frank J. Cilluffo and Joseph R. Clark

Operationalizing Cyber

Kevin C. Benson

Policy, Strategy, \& War Planning 


\section{DepartMents}

5 From the Editor

\section{Commentaries and Replies}

125 On "Regionally Aligned Forces: Business Not as Usual" Richard H. Sinnreich The Authors Respond

135 On "Imbalance in the Taiwan Strait"

David Lai Dennis V. Hickey Replies

138 On "US Options in Syria" Nathan Finney
173 Article Index, Vol. 43, 2013

128 On "Strategic Landpower in the Indo-Asia-Pacific" Jeong Lee

131 On "Strategic Landpower in the Indo-Asia-Pacific"

James D. Perry

John R. Deni Replies

\section{Book Reviews}

\section{Armed Nonstate Groups}

141 Global Security Upheaval: Armed Nonstate Groups Usurping State Stability Functions By Robert Mandel

Reviewed by José de Arimatéia da Cruz

145 Al-Shabaab in Somalia: The History and Ideology of a Militant Islamist Group 2005-2012

By Stig Jarle Hansen Reviewed byRichard J. Norton
144 The Complexity of Modern Asymmetric Warfare By Max G. Manwaring Reviewed by Robert J. Bunker

148 New Security Challenges in Asia Edited by Michael Wills and Robert M. Hathaway Reviewed by Jeong Lee

\section{Policy, Terror, \& Espionage}

150 Kill or Capture: The War on Terror and the Soul of the Obama Presidency

By Daniel Klaidman

Reviewed by W. Andrew Terrill

153 Constructing Cassandra: Reframing Intelligence Failure at the CIA, 1947-2001 By Milo Jones and Philippe Silberzahn Reviewed by W. Ross Clark
152 Intelligence Elsewhere: Spies and Espionage Outside the Anglosphere Edited by Philip H.J. Davies and Kristian C. Gustafson Review by Joseph Becker

\section{Strategic Leadership in Wartime}

156 The Men Who Lost America: British Leadership, the American Revolution, and the Fate of the Empire By Andrew Jackson O'Shaughnessy Reviewed by James D. Scudieri

159 The Swamp Fox: Lessons in Leadership from the Partisan Campaigns of Francis Marion By Scott D. Aiken Reviewed by Jill Sargent Russell
158 On the Precipice: Stalin, the Red Army Leadership and the Road to Stalingrad, 1931-1942

By Peter Mezhiritsky

Reviewed by Stephen Blank 
New Perspectives on Vietnam

162 Kill Anything That Moves: The Real American War in Vietnam

By Nick Turse

Reviewed by William Thomas Allison
164 Vietnam Labyrinth: Allies, Enemies, and Why the US Lost the War

By Tran Ngoc Chau, with Ken Fermoyle

Reviewed by William Thomas Allison

165 Losing Vietnam: How America Abandoned Southeast Asia

By Ira A. Hunt, Jr.

Reviewed by David Fitzgerald

\section{Revisiting the Great War}

168 The Last of the Doughboys: The Forgotten Generation and Their Forgotten World War By Richard Rubin

Reviewed by Michael S. Neiberg
169 Winning and Losing on the Western Front: The British Third Army and the Defeat of Germany in 1918

By Jonathan Boff

Reviewed by Dean A. Nowowiejski

\section{New Award to Recognize Contributors}

We would like to take this opportunity to announce a new award to recognize the author (or authors) who made the most significant contribution to the theme of Strategic Landpower in a given volume of the Quarterly. Our Editorial Board will nominate the winner(s) from those articles published by the journal within a given volume year. The award will be presented by the Commandant of the US Army War College, and will include a certificate and cash prize. More details will be forthcoming in the next issue of the Quarterly. 



\section{From the Editor}

eaders will want to note the edifying, if contentious, exchange between two distinguished soldier-scholars, Charles Dunlap and Conrad Crane. Each holds strong views regarding the assumptions and attendant expectations that have underpinned and continue to shape the American way of fighting. We also wish to draw readers' attention to the thoughtful responses we received to our "Women in Battle" forum (Summer 2013), and the authors' replies.

Our first forum looks at four "Dilemmas for US Strategy." One factor that makes formulating strategy difficult, especially for a global power, is that policy choices in one region can reduce alternatives in another. David Sorenson's "US Options in Syria” weighs America's military and nonmilitary options against the goal of containing the Syrian civil war, noting that the failure of the current containment strategy could lead to dire consequences for the region. In "Pitfalls in Egypt," Gregory Aftandilian discusses how antipathy toward the United States grew during the Morsi presidency, and how America can chart a better course by using aid packages to encourage democratic reform. Richard Weitz's "Transition in Afghanistan" suggests that NATO's withdrawal may be too soon to avoid a renewal of the Afghan civil war. Dennis Hickey's "Imbalance in the Taiwan Strait" examines four alternatives for addressing the military imbalance between Taiwan and China, and recommends combining two of them for a better way ahead.

The second forum presents "US Landpower in Regional Focus." In the first article, Brigadier General Kimberly Field, Colonel James Learmont, and Lieutenant Colonel Jason Charland explain the rationale and principal components of the Regional Alignment of Forces concept. Andrew Terrill's "Strategic Landpower and the Arabian Gulf" describes how the US Army has played a stabilizing role for the Arab states along the Persian Gulf, and can continue to do so. John Deni's "Strategic Landpower in the Indo-Asia-Pacific" discusses the US Army's contributions to deterring aggression and to promoting security in the region. In both cases, it is clear the strategic application of landpower offers much more than compellence.

Our third forum, "Lessons from Limited Wars," highlights what we might learn from some of America's limited conflicts. It opens with "A War Examined: Afghanistan" by Todd Greentree, which considers the ambiguous results of America's most recent conflict and what these might mean for the concept of limited war. David Brooks's "Cutting Losses: Ending Limited Interventions," offers three case studies to analyze how US presidents decided when the costs of a limited intervention exceeded its benefits.

This issue also offers a mini-forum on "Examining Warfare in Wi-Fi." Contributions by Paul Kan and Jeffrey Groh review some of the latest literature on cyberwar and cyber warfare, a topic of increasing interest. $\sim \mathrm{AJE}$ 



\title{
What the QDR Ought to Say about Landpower
}

\author{
Francis G. Hoffman
}

(C) 2013 Francis G. Hoffman

\begin{abstract}
AвStRACт: The 2014 Quadrennial Defense Review (QDR) will have been completed as of this writing, but will not yet have been published. Facing new strategic priorities and mounting fiscal pressures, it is anticipated that the capacity or size of American landpower will be substantially reduced: the Army's end strength could be decremented to a post-World War II low of just 420,000 to 450,000 soldiers. This article considers the implications of such reductions.
\end{abstract}

he US Department of Defense (DOD) faces numerous challenges today as it updates US defense strategy in light of a dynamic security environment and significant resource constraints. The QDR affords landpower strategists an excellent opportunity to step back and think about the future. As the former Pentagon strategist Shawn Brimley wrote, "With wars ending, budgets declining, technology proliferating, and other powers rising, a real window of opportunity to reshape US defense strategy has opened for the first time since the end of the Cold War."1 However, that "window" also brings with it great risk.

Documents like the National Intelligence Council's 2030 report or the Joint Chiefs of Staff Joint Operating Environment suggest the United States must have balanced and versatile forces able to accomplish a wide variety of missions. Urgency is needed to create greater Joint adaptability and versatility to cope with uncertainty and complexity. Although niche capabilities will still be needed, a balanced force design is the basis for adaptation and operational flexibility.

\section{Landpower and Joint Force 2020}

Landpower's role in the 21st century was studied by a task force commissioned by the US Army, US Marine Corps, and Special Operations Command. This effort produced a concept paper delineating what landpower brings to the fight, and emphasizes achieving influence in the human domain and winning the clash of wills inherent in human conflict. ${ }^{2}$ It argues, persuasively, that "the importance of conflict prevention and the ability to shape conditions in regions to maintain stability through actions highly focused on human factors is also rising in significance." 3 The interplay of human and moral factors in war is something Clausewitz stressed, but which modern strategists might deemphasize or inadvertently overlook. ${ }^{4}$

1 Shawn Brimley, "The Next QDR is the Last Chance for Sanity," Defense One, July 15, 2013.

2 Raymond T. Odierno, James F. Amos, and William H. McRaven,Strategic Landpower; Winning the Clash of Wills (Washington, DC: May 6, 2013), www.arcic.army.mil/app_Documents/StrategicLandpower-White-Paper-06MAY2013.pdf.

3 Ibid., 3.

4 Dima Adamsky, The Culture of Innovation, The Impact of Cultural Factors on the Revolution in Military Affairs in Russia, the US, and Israel (Stanford, CA: Stanford University Press, 2010).

Mr. Francis G. Hoffman currently serves as a Senior Research Fellow at the Institute for National Strategic Studies, National Defense University. 
The role of landpower is questioned in some quarters: it is equated to protracted counterinsurgency tasks and portrayed as expensive. Some critics think of the Army and Marines solely in terms of current conflicts in Afghanistan and Iraq, and hope to opt out of such "messianic" missions and nation-building tasks. But after a decade of irregular war, the contributions made by the Army, Marines, and Special Operations Forces (SOF) should not be narrowly defined by the last decade or exaggerated concerns about "endless wars." American landpower capabilities have been broadened and deepened by a decade of sacrifice and adaptation. The tremendous learning curve and combat experience of the last decade has produced a very flexible force, and the United States must retain the best of that leadership, experience, and lessons. We should not seek to refight the last war, nor should we recoil from a ruthlessly realistic appreciation for the world as it is rather than what we hope it may become. As noted by Major General H. R. McMaster:

\footnotetext{
... in Afghanistan and Iraq, planning did not account for adaptability and initiatives by the enemy. American forces, deployed initially in insufficient numbers to keep pace with the evolution of those conflicts, struggled to maintain security. The lesson: The wars in Iraq and Afghanistan, like all wars, were contests of will that unleashed dynamics that made future events impossible to predict. Fortunately, American forces adapted. ${ }^{5}$
}

The US military has not yet studied or drawn adequate lessons about the factors that facilitated this adaptation.

Some national security analysts have questioned whether landpower is necessary. Landpower is part of the Joint capability package and heavily counted on to secure decisive results. Whether the debates center on the missions, costs, or effectiveness, one should be wary of those critics promoting a new "Vietnam syndrome," arguing the United States should never again go down the path it did over the last decade. ${ }^{6}$ Playing to this syndrome led directly to the problems encountered before, during, and after the invasions of Iraq and Afghanistan. Some critics argue for limited interventions or ideal conditions, "more El Salvadors" than Vietnams or more short wars like Operation Desert Storm. The desire for more Desert Storms and fewer Iraqi Freedoms is understandable. But strategists cannot plan for convenient enemies-leaders who array their forces in open desert terrain, who have no means to defend themselves against US ground and air power, and thereby enable short, decisive wars culminating in flower-strewn victory parades. ${ }^{7}$ But the future does not bend to our preferences. To think there will not be messy conflicts is to harbor dangerous illusions. ${ }^{8}$

Technology cannot offset the need for robust ground forces, nor can it guarantee short wars. The policy community may not have fallen for

5 H. R. McMaster, “The Pipedream of Easy War," The New York Times, July 21, 2013.

6 John Deni, "Land Power is Still Necessary," The National Interest, June 4, 2013, http://nationalinterest.org/commentary/land-power-still-necessary-8544.

7 Steven Metz and Douglas C. Lovelace, Jr. "Don't Give Up on Ground Troops," The New Republic, April 9, 2013.

8 Allegedly the President has asked for fewer Iraqi Freedoms and more Desert Storms, see James Kitfield, "A Hollow Military Again?” National Journal, June 12, 2013, http://www.nationaljournal. com/congress/a-hollow-military-again-20130612. 
"easy wars" or been seduced by the "lure of strike." However, recent defense studies suggest that the "technological optimists" are alive and well again. ${ }^{10}$ We must be wary of their claims, having fallen for them too many times already, at too tragic a cost.

Landpower confers the ability to create and apply control of terrain and populations. When control is central to a strategy, landpower generates it. It is both high risk and high reward.

\title{
Strategic Planning and Landpower
}

The Pentagon's strategic guidance includes a shift to the Asia-Pacific region, a theater presumed to have a principally maritime character. ${ }^{11}$ The Pentagon's guidance is on target in terms of priorities. With the pivot to the Pacific, some superficial analysis has suggested,

\begin{abstract}
It makes sense to shift resources toward maritime forces. Wars in that region are more likely to be fought at sea than on land. Moreover, if the United States is planning to avoid future stability and counterinsurgency operations, like those in Afghanistan and Iraq, which require large numbers of boots on the ground over multiple rotations, then the military will need considerably fewer ground forces." 12
\end{abstract}

But landpower is certainly not irrelevant to negating anti-access challenges, nor irrelevant to security challenges in the Pacific. ${ }^{13}$ There is certainly ample opportunity for the Army, Marines, and Special Operators to enhance regional security throughout the Pacific. ${ }^{14}$

Furthermore, while American geostrategic interests in the Persian Gulf may diminish as the United States exploits the shale oil and gas revolutions, no projection of American security interests can ignore the complexities of political and social change in the Middle East, Africa, South America, or Central Asia. ${ }^{15}$ The Joint Force will require landpower resources to advance US interests in those regions.

Landpower requirements are generated by DOD's strategic planning and resource allocation processes. The unpredictability of long-range challenges makes that generation difficult. Force diversity is a healthy antidote to the all too common failure to predict. ${ }^{16}$ Long-range planning is essential; but the enemy does not have to respect US planning assumptions and theories of victory, nor fight in an accommodating manner.

9 One scholar contends that technological enthusiasm has historically led to strategic overreach and unbalanced force designs, see Conrad Crane, "The Lure of Strike," Parameters 43, no. 2 (Summer 2013): 7-17.

10 Mackubin T. Owens, "Reflections on Future War," Naval War College Review, 61, no. 3 (Summer 2008): 62-73.

11 Leon Panetta, Sustaining U.S. Global Leadership, Priorities for 21st Century Defense (Washington, DC: Department of Defense, January 5, 2012), 6.

12 Cindy Williams, "Accepting Austerity: The Right Way to Cut Defense," Foreign Affairs (November/December 2013).

13 Jim Thomas, "Why The U.S. Army Needs Missiles," Foreign Affairs (May/June 2013), 114-120. 2013).

4 John R. Deni, "Strategic Landpower in the Asia-Indo-Pacific," Parameters 43, no. 3 (Autumn

15 Michael R. Eastman, "American Landpower and the Middle East of 2030," Parameters 42, no. 3 (Autumn 2012): 6-17.

16 Richard Danzig, Driving in the Dark: Ten Propositions About Prediction and National Security (Washington, DC: Center for a New American Security, October 2011). 
Supposing that tomorrow's adversaries will be only elusive guerrillas or that armored forces are passé is risky. ${ }^{17}$ Similarly, future crises will require more than special operators. Integrated solutions applying all three elements of the landpower triad (Army, Marines, and Special Forces) will be needed. As noted in one report by the Center for Strategic and International Studies (CSIS), "the unique contributions of ground forces - the ability to take and hold terrain, operate discriminately in close proximity to vulnerable populations, and instill confidence in allies and partners - will be no less vital in the coming decade." ${ }^{18}$ Other recent Defense Department-sponsored research finds that large-scale interventions are not implausible, but US ground forces may need to broaden their capability portfolios. ${ }^{19}$ Of paramount concern is the full spectrum of warfare from major combat operations, stability operations, and irregular warfare operations. These require persistent, steady-state contributions from all three elements of the landpower triad.

The QDR results should refine the Defense Strategic Guidance (DSG) regarding stability operations, incorporating one small-scale stability operation in its planning scenarios (much smaller than Operations Iraqi Freedom or Enduring Freedom). Planning for a 12- to 24-month, medium-scale stability operation every 3 to 5 years would be a prudent hedging strategy for a global power such as the United States. Something like a Balkans or Libya operation is a rough scale. The current guidance admits that US forces must be prepared for a full range of operations, but it also states that the United States will seek to avoid substantial engagement and prefers nonmilitary solutions. This suggests that training, preparation, and readiness for such missions is a low priority and a poor allocation of time and resources. Furthermore, it does not authorize any capacity. ${ }^{20}$ This has the unintended effect of retarding the institutionalization of irregular warfare as an equal warfighting capability to conventional conflict, the lessons learned from a decade of war, and the necessity of stability operation capabilities by the Army and Marines.

\section{Force Sizing}

To gain further traction with the policy community, landpower leadership will have to present a compelling rationale for both future capabilities and capacity. Fuzzy notions or historical bromides will not suffice. ${ }^{21}$ From a Total Force perspective, today's 1.15 million person landpower "Triad" is impressive both qualitatively and in terms of capacity. The sum landpower capacity in this "triad" includes the active and Reserve/Guard elements from the Army, Marines, and SOF. Even with planned reductions of nearly 100,000 Marines and Soldiers, the United States will still have over a million Soldiers and Marines led by battle-hardened professionals. We should retain a robust force, with the

17 An argument laid out effectively in Chris McKinney, Mark Elfendahl, and H. R. McMaster, "Why the U.S. Army Needs Armor: A Case for a Balanced Force," Foreign Affairs (May/June 2013); David E. Johnson, Heavy Armor in the Future Security Environment (Santa Monica, CA: RAND, Occasional Paper, 2011).

18 Nathan Freier, U.S. Ground Force Capabilities Through 2020 (Washington, DC: Center for Strategic and International Studies, October 2011), vii.

19 Nathan Freier, Beyond the Last War: Balancing Ground Forces and Future Challenges Risk in USCENTCOM and USPACOM (Washington, DC: Center for Strategic and International Studies, April 2013).

20 Panetta, Sustaining U.S. Global Leadership, 6.

21 Peter Singer, "From Fuzzy to Focused," Armed Forces Journal, November 2013. 
diverse mix of capabilities (armor, mechanized, special operations, and forcible entry) that we now possess.

The force-sizing construct the Pentagon used in this QDR is not yet clear. But the DSG suggests the United States is prepared to respond to two different kinds of major regional conflicts (MRCs). In one, the United States will deploy a highly modernized and balanced Joint combined arms force to obtain decisive results, including full regime change. In the second, the Pentagon intends to punish a country, or to deny it from achieving the fruits of any aggressive action. This second scenario is presumably dependent on strike assets and short on any ground forces for security of allies or for stability operations in support of either the ally or partner, or in any contested space impacted by the kinetic phase of the operation. These shortfalls may be necessitated by sequestration and limited dollars, but they pose risks for force planners to consider and mitigate.

At least 18-20 Brigade Combat Teams (BCTs) may be required for one MRC. Another 3 to 4 BCTs would be forward deployed at any time, and this would require a total of $12 \mathrm{BCT}$ Ts to ensure a sustainable rotation basis and adequate training readiness. This rationale might suggest we need an Army of 30 to 32 maneuver BCTs. However, the minimum Army force structure is not simply the sum of these two major requirements. Presumably, some part of the forward deployed force will be postured in the critical region, and engaged at the onset of a conflict. Counting the earlier proposal for a stability scenario, a requirement to retain no less than 32 active $B C$ Ts with moderate risk appears valid. The challenge for Army leaders and force planners is the requisite reductions in the institutional army, force generation capacity, and infrastructure to free resources to preserve this core component of the Army. Significant reductions in base overhead and civilian personnel will be required, as many as one third of all civilian billets may be reduced over the Future Years Defense Program to preserve the deployable core of the US landpower force.

While overall force size is not irrelevant, the quality and readiness of the force matter. ${ }^{22}$ There has been too much emphasis on the quantity and size of each service, and not enough on quality and future concepts. It is unwise to retain a larger force structure than one can properly train and equip. The QDR should reflect that, even if fiscal limits drive down capacity and drive up strategic and operational risks.

Realistic thinking is also needed about what is occurring among traditional US allies and partners. North Atlantic Treaty Organization (NATO) force reductions need to be factored in as they are announced. As noted by RAND, "The result of the anticipated cuts and future financial constraints is that the capacity of the major European powers to project military power will be highly constrained." ${ }^{23}$ This reduced capacity will mean an even greater burden for the United States in allied and partner operations.

22 Frank G. Hoffman and Mike Noonan, "Defense Reorganization Under Sequestration," (Philadelphia, PA: Foreign Policy Research Institute), July 2013.

23 Frank Larabee et al., NATO and the Challenge of Austerity (Santa Monica, CA: RAND, MG1196-OSD, 2012); Steven Erlanger, "Shrinking Europe Military Spending Stirs Concern," The New York Times, April 23, 2013. 


\section{Total Force Mix}

The active/reserve force mix presents additional issues with regard to readiness and risk. At present, the US military has a total of 18 divisions in the Army and National Guard (10/8 respectively), and another 4 in the Marine Corps, including its single reserve division. Planned reductions will cost the Army approximately two Division equivalents (10 to 12 Brigades), and the Corps approximately two of its nine regiments. How much combat power is needed in the Active Component, and with what mix of capabilities?

Proposals vary from one think tank to another, but increasing the readiness or size of the reserve component may preserve the capacity needed within sharp funding constraints. ${ }^{24}$ While much progress was made in the last decade, more can be leveraged from a properly resourced Reserve Component. ${ }^{25}$ In planning for austere times, the United Kingdom shifted toward a higher reliance on its reserve component, and there are calls in the United States to do the same. ${ }^{26}$ The QDR must carefully consider how this can be done to preclude a degradation in conventional deterrence or the ability to respond to crises in a timely manner. Moreover, one needs to be realistic about limited reserve training time. The complexity of modern warfare suggests the Age of the Minuteman is long gone. ${ }^{27}$ Shifting missions and risk to the Reserves may be a smart call to mitigate uncertainty, but it is the wrong way to cut defense. We need a far more rigorous assessment of Reserve and Guard response timelines, and a better idea of what is necessary to place a greater reliance on the Reserve Component.

Assessments of risk, readiness, and required response timelines need to be conducted and validated. ${ }^{28}$ Allies face unruly neighborhoods far abroad. Simply shifting forces into the Reserve, and expecting warning and mobilization times of six months or nearly a year are not consistent with preserving stability, reassuring our allies, or meeting treaty obligations. ${ }^{29}$ That is the wrong way to cut defense

Special Operations. Current guidance, as well as General David Barno's notion of future "Wars of Shadow," define a need to preserve if not extend Special Operations capacity. ${ }^{30}$ Obviously, US special operations forces should be sized to provide their unique capabilities across the conflict spectrum, not just for direct action or for building partner

24 Todd Harrison et al., "Strategic Choices Exercise Outbrief," (Washington, DC: Center for Strategic and Budgetary Assessments, May 29, 2013), http://www.csbaonline.org/ publications/2013/05/strategic-choices-exercise-outbrief/.

25 John Nagl and Travis Sharp, An Indispensable Force, Investing in America's National Guard and Reserves (Washington, DC: Center for a New American Security, September 2010), 9.

26 Clark Murdock, "Strategic Choices Exercise Outbrief," (Washington, DC: Center for Strategic and Budgetary Assessments, May 29, 2013).

27 Julian Tolbert and Stephen J. Mariano, "Time for Minutemen is Past," Philadelphia Inquirer, June 2, 2013, http://articles.philly.com/2013-06-02/ news/39693054_1_world-war-ii-u-s-army-u-s-air-force

28 Bill Hix and Bob Simpson, "In strategy, 2 out of 3 is bad: Proposed Army cuts go dangerously astray," Armed Forces Journal International, June 2013.

29 Williams, "Accepting Austerity."

30 For more recommendations see Linda Robinson, The Future of U.S. Special Operations Forces (New York: Council on Foreign Relations, Special Report No. 66, April 2013). 
capacity or engagement. ${ }^{31}$ Investments are required to ensure this, including some continued growth in the Special Operations Command in the next few years. Modernization for special operators cannot be overlooked. As Admiral McRaven noted earlier this year, "Mobility, lethality, intelligence, surveillance, reconnaissance and survivability remain critical SOF enablers for the full spectrum of SOF operations." 32 The QDR should ensure these enablers are procured.

Enhanced interdependency between conventional and special forces is also desirable. However, our Special Forces will be consumed with Wars of Shadow, and the rest of the triad will have to support missions of long duration, patiently developing long-term relationships for successful partnerships, training and advisory tasks, and capacity building. ${ }^{33}$

Human Domain Investments. As noted in the Strategic Landpower White Paper, "the success of future strategic initiatives and the ability of the United States to shape a peaceful and prosperous global environment will rest more and more on our ability to understand influence, or exercise control within the human domain." 34 Joint doctrine may not need to institutionalize a Human Domain, but it is one way for the Office of the Secretary of Defense (OSD) and the services to ensure valuable lessons and programs from the last decade of war are not inadvertently shed in the struggle for fewer resources. Key human terrain, educational, and sociocultural programs are being phased out due to fiscal constraints. These programs are often associated with humancentric or irregular conflicts, when they are actually relevant to strategic influence, and the entire range of military operations. Such trends will not enhance America's ability to influence events in an increasingly competitive environment. Engineering and technology are national fortés, and we should continue to exploit them, but we should also try to close the gaps between ourselves and foreign cultures. ${ }^{35}$

\section{Conclusion}

The QDR process is more important than the final document, and represents a critical opportunity to shape future US defense strategy and tomorrow's land component. Policymakers must examine trends to anticipate myriad conflicting dynamics. Many features of the world looming ahead are not new, and reflect enduring elements of human conflict. Other aspects reflect both evolutionary and revolutionary possibilities. While technology should be sought to afford US forces a relative advantage, it should not be pursued in lieu of regard for context or in a mistaken belief that it produces decisive results by itself.

We need to be more humble about our track record when it comes to strategic foresight. According to some, over-optimism is an enduring

31 Admiral William H. McRaven, U.S. Navy, Posture Statement of Admiral William H. McRaven, USN, Commander, United States Special Operations Command Before the 113th Congress Senate Armed Services Committee, March 5, 2013, http://www.armed-services.senate.gov/statemnt/2013/03\%20March/ McRaven\%2003-05-13.pdf.

32 Ibid., 11.

33 David Maxwell, “Thoughts on the Future of Special Operations," Small Wars Journal, October 31, 2013.

34 Odierno, Amos, and McRaven, Strategic Landpower, 3.

35 Anna Simons, 21st Century Cultures of War (Philadelphia, PA: Foreign Policy Research Institute, April 2013). 
element in the American Way of War. ${ }^{36}$ Our record of prediction is actually fairly good, we are always optimistic and always wrong. War is a perennial reality, yet one that we must try to prevent and limit in terms of both frequency and consequence. Landpower will continue to play a critical role in this task, as long as we have enough of it.

36 Donald Chisholm, "The Risk of Optimism in the Conduct of War," Parameters 33, no. 4 (Winter 2003/2004): 114-131; Joseph Collins, “Of Groundhogs and Ground Combat," Small Wars Journal, April 11, 2013. 


\section{The True Tragedy of American Power}

\author{
Isaiah Wilson III \\ (C) 2013 Isaiah Wilson III
}

\begin{abstract}
Aвstract: American distaste for tragedy has led US strategists and policymakers to mistake mere force for power. Understanding the difference between force and power is vital to America's rise as a durable and balanced global power, and not merely as a forceful hegemon. This understanding is all the more imperative at a time of compounding global security challenges and austerity.
\end{abstract}

What individuals do is related to what they think. ... Since wars begin in the minds of men, it is in the minds of men that the defences of peace must be constructed. ${ }^{1}$

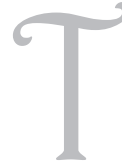

here is a fine line between a tragic hero's flaw and his virtue. The classic tragedies - those of Sophocles and Shakespeare, for instance-present a noble protagonist, "better than we" to the audience. His tragic flaw causes him to fall from prosperity to misery through a series of reversals and discoveries. In a typical case, the hero's fall occurs in stages: Act I introduces the hero, against whom dark forces align in Act II so by Act III it becomes clear to the audience (and sometimes to the hero) that his fate will be the opposite of what he hoped; the catastrophe of Act IV exposes the limits of the hero's power, and Act V secures our recognition (in a moment of "catharsis") of the larger patterns at work in the play. What makes tragedy so poignant is not only how it shows human beings as the playthings of fate, but how it reveals that fate lurking in our own characters, so close to the qualities we cherish as to be indistinguishable from them. The same pride and probity that make Oedipus excel as king lead him to overestimate his strength and self-sufficiency; the same profundity and eloquence that make Hamlet a compelling individual make him a dilatory and ineffective agent. If these heroes could see their virtues within their proper bounds, they would no longer be the subjects - the victims — of tragedy. But they cannot and so they are.

American stories tend to resemble not tragedies so much as classic comedies, with happy endings and no loose ends. And yet a certain tragic sensibility recently entered into our political discourse. We increasingly sense the limits of not only our budgets, but our power to act as we would like in the wider world. We sense ever more palpably the frustrations of power and feel ever more fleetingly the privileges it affords. Like a tragic hero as the pivotal third act draws to a close, we feel ourselves at once flawed and incapable of isolating our flaw in time to save ourselves.

One dimension of our tragic flaw is this taste for happy endings itself. Among its myriad manifestations is the want of tragic sensibility in our strategic culture, which persists even as our broader political discourse becomes ever more somber. In this article, I show, first, how American distaste for tragedy has led US strategists and policymakers to mistake

1 Francis Beer, Meanings of War and Peace (College Station: Texas A\&M University Press, 2001), 6.
Colonel Isaiah (Ike) Wilson III is a former Director of American Politics, Policy, and Strategy Program at West Point as well as founding director of the West Point Grand Strategy Program. He holds a BS from USMA, MS from Cornell, the National War College, CGSC, SAMS, and a Ph.D. from Cornell University. He has authored many publications, including Thinking Beyond War, 2007. 
mere force for power. I want, then, to show how vital this differentiation between "force" and "power" has been to America's rise as a durable and balanced global power, not merely a hegemon. It is important for us to appreciate this distinction all the more as we rethink America's legitimate and possible roles as the leading power in the future. Finally, I will suggest what an American grand strategy informed by a sense of tragedy_ as opposed to a tragic grand strategy—might look like.

\section{Power and Force}

Newton teaches us as much about the tragedy of power as Sophocles or Shakespeare. As every graduate of Physics 101 knows, Newton defined power with the following equation:

$$
\text { Power }=\frac{\text { Force } x \text { Displacement }}{\text { Time }}
$$

Newton could not account for power without force, but he did not consider the two to be identical. In addition to force, one must account for both time and displacement, the imaginary straight path from the initial and final positions of a point, and the length and direction of which one expresses in the "displacement vector." All these variables stand in harmonious symmetry in nature as reflected in Newton's equation.

There are multiple definitions of power, but its essence is the capacity to effect change and the ability to influence others. ${ }^{2}$ This is the foundation for Joseph Nye's dissection of hard and soft power. ${ }^{3}$ Where power was once based on geography, population, and raw materials, today the basis lies increasingly on technology, education, and economic growth. Hard power, whicK physically compels or directs other states to act in a manner consistent with the goals of the state, typically appears in the form of incentives or threats to alter what another state does. ${ }^{4}$ This hard power assumes various forms: the size and capacity of the economic marketplace, political influence, and military strength most notably. The United States has used these forms of hard power to achieve its goals since its birth, but just as important has been soft power. Soft power, instead of inducement or coercion, co-opts and attracts; it shapes and changes what other states want. ${ }^{5}$ Quite simply, soft power is getting others to do what you want. It influences others because of attraction, and the means of soft power are less tangible but no less potent: values, culture, ideology, and institutions.

The United States has seen many of its policy objectives achieved in part due to its soft power. American ideals stood in stark contrast to those of Soviet communism and acted as a beacon for citizens trapped behind the Iron Curtain. In considering hard and soft power, where does the discussion of force begin?

\footnotetext{
$1-2$.

2 Joseph Nye, Soft Power: The Means to Success in World Politics (New York: Public Affairs, 2004),

3 Joseph Nye, Bound to Lead: The Changing Nature of American Power (New York: Basic Books, 1990), 25-26.

4 Ibid., $31,267$.

5 Ibid., 267.
} 
Force, of which military power is only one element, is the most blatant display of power. ${ }^{6}$ Power and force have a unique relationship and are too easily conflated, contributing to errors in strategic judgment and actions. While military force is an essential element of American national power, it is neither the only essential element nor is it a sufficient proxy for American power. In terms of politics, power rests on a state's prestige and capacity to cause or prevent change, and it requires legitimacy, which it derives from those who may be subject to it. True power is self-legitimizing, purposeful, and strategic in securing national interests. As such, power grows when others recognize the capacity, latent or otherwise, a state possesses. Force, on the other hand, consists of the tools that a state employs as an extension of its power, and when employed without legitimacy and strategic purpose, may be very dangerous for the state that does so. Power is the foundation of force; but an excessive employment of force-not just military, but economic and political_can erode the power foundation. Paradoxically, the recognition of power comes from the display of force, but when states employ force excessively, it may lead to a decrease in power. The unmistakable link between power and force may, in fact, be found in national will and legitimacy. The longer a state employs force, the greater the potential for a decrease in national will, which may eventually result in the diminution of power.

\section{Reconsidering American Power}

For long stretches of US history, the basis of constitutional discussions centered on how to maximize liberty and prosperity, and how to organize force with a view to preserving them. The goal was sufficient centralization of force to ensure citizen's rights and no more than the minimum necessary to protect and ensure liberty. It was only in a Constitution so conceived that the unionist's slogan, "join or die," could coexist with the revolutionary's Don't Tread on Me! By using principle to restrain force, the ends of government to limit and define its means, the founders understood, the nation could generate true power.

Where does American power stand today? From one vantage point, US power seems unsurpassed. The United States is not only a memberstate of a global community of nation-states, but its leader. And the global community - at least insofar as it is defined by global trade, humanitarian impulses, and other touchstones of American liberalism-is itself the American regime writ large. In this sense, the United States is not merely part of the system; it is the system. As a result, US domestic politics and policy determinations have widespread consequences beyond American shores. Also as a result, American strategists feel a special responsibility to guarantee the stability of the system as a whole.

Seen another way, however, American power not only checks but undermines itself by appearing only in the guise of force. American military force has had a mixed record of success, particularly over the past decade in Afghanistan and Iraq. These and other irregular wars and military-humanitarian operations (MHOs) the United States has engaged in have demonstrated the inability of mere military force to

6 Hannah Arendt, "On Violence," Crises of the Republic (New York: Harcourt Brace Jovanovich, 1972), 134. 
generate the conditions necessary to resolve conflicts: political agreement among internal factions, improved capacity in host nation civil governance, and increased economic development. Force of arms can bring down regimes with far greater ease than it can build them up. Partly as a result of the prominence of force in the American disposition toward the world, the persuasive and alluring aspects of America's soft power-its ability to attract other states through its ideals, ideas, and culture-is also in question. And with good reason, as the United States' focus on force led it in many cases to compromise its own core ideals with greater effectiveness than any enemy could have done.

This, then, is the heart of the tragic paradox we face: a system of government that generates power by restraining force has produced a nation commanding unparalleled force, and with it the tendency to place force rather than power at the core of its international relations. As the founders knew, military force is an essential element of American power. But this power rests equally on its capacity to effect or prevent change by means of its prestige and legitimacy, which have as much to do with the opinion of those subject to American power as with the opinions of Americans themselves. True power is legitimate, purposeful, and strategic in securing national interests. The nation founded on such a notion of power, yet bewitched with its own force resembles nothing so much as the tragic hero tilting toward his drama's climax.

The United States' successful efforts to open markets are partially responsible for its tenuous economic situation, and may potentially lead to political backlash domestically. ${ }^{7}$ A worsening economic condition for the United States may result in an inability to garner the necessary will for further uses of economic force. ${ }^{8}$ The ongoing wars in Afghanistan and Iraq have strained the United States politically and economically. Of late, the United States may have experienced a decline in its power due to an excessive utilization of force and the greater use of force in lieu of leveraging its latent power capacity. It has become imperative that national decisionmakers, policymakers, and the American public alike, begin to tackle directly and outright this complex and often paradoxical interplay between American power and American force. ${ }^{10}$

\section{Legitimizing American Power}

Legitimate power in the American tradition was originally conceived as limited power, with an intentional emphasis on balance, durability,

7 Glenn Somerville and Chris Buckley, "China and US Each Claim Gains on Yuan Talks," Reuters News, May 25, 2010, http://www.reuters.com/article/idUSTRE64M09Q20100525.

8 Bruce Bartlett, "How Deficit Hawks Could Derail the Economy," Forbes, January 8, 2010, http://www.forbes.com/2010/01/07/deficit-great-depression-recovery-opinions-columnistsbruce-bartlett.html.

9 The political effects of the United States' actions have been the subject of several analyses, including Andrew W. Terrill, Regional Spillover Effects of the Iraq War, Strategic Studies Institute, January 6, 2009; and Les Gelb, "Karzai Bests Obama, For Now," Council on Foreign Relations (May 11, 2010); Joseph Stiglitz and Linda J. Bilmes, The Three Trillion Dollar War: The True Cost of the Iraq Conflict (New York: W. W. Norton \& Co, 2008).

10 The prominent use of its military, international democratization efforts, and uses of economic statecraft in pursuit of national objectives are utilizations of force that may have affected the power/ force equilibrium of the United States. 
certainly energy ... but importantly, also modesty. ${ }^{11}$ America's approach to power was originally an enterprise in the construction, constitution, and assurance of a "minimalist state of power" - just enough centralization of power to ensure citizen's rights and no more than that minimum so as to protect and ensure liberty. The key political considerations in connection with power were to be found not in physical force as an end-all, but rather in the questions of justice and authority, i.e., what is the moral and legal status of power? Looking back even further, in the American tradition and to the nation's grounding in Scottish Common Sense philosophy, the view of power was/is that it is morally neutralnot bad or good in and of itself - that its goodness or badness depends more on how it is used, when, and for what purposes. In short, American Power, traditionally and to remain consistent with who we are, who we have been, and who we intend to continue to be in the future, as a republic, must always be purpose-driven, not ways-and-means determined. Author, journalist, and political commentator, Leslie H. Gelb, offers a useful contemporary commentary on the tenets of power, in his book, Power Rules: ${ }^{12}$

- "Power was never to be considered in soft or hard terms" This is actually more a way of categorizing "force" not power. Power is not fungible and divisible in that way. Power is, and was, essentially the capacity ("the ability to ... ") to get people to do what they otherwise don't want to do, by pressure and coercion, using one's resources and position. Persuasion, values, and the use of force can and often do flow into power, but at its core, power is psychological and political pressure.

- "Power equals capacity." Tracing the development of the word from its ancient Greek and Latin origins, we find Power defined and understood to mean nothing more than "ability" as a noun and "to be able" as a verb. Being a Power as a nation, much less a Great Power, is about being able and in a position to compel others to your will; it is psychological and political action. In that respect, the description of Power is synonymous to the Clausewitzian theoretical concept of war-an act of policy (i.e., what governments choose to do and choose not to do), and as such, a continuation of politics by other means. Power is a grapple. It derives from establishing psychological and political leverage or advantage by employing resources (i.e., wealth, military capability, commodities, etc.), position (such as geographic regional balancer or political protector), as well as maintaining resolve and unity at home. Power, thus, varies with each and every relationship and changes with each and every situation. It has to be developed and shaped in almost each and every situation, and will vary over time and place. Critically, the wielder of power must take great care to be credible to be taken seriously, both at home and abroad.

- "Having a 'base of Power' is much more than a simple adding up of resources." It depends on the kind and nature of those resources-namely, a nation's relative self-sufficiency and resilience once a power struggle

11 A full and comprehensive review of the Founding and Framing era literature is well beyond the limits of this short article. However, a definitive and authoritative compendium source is found in The Federalist Papers. Source for this article is Clinton Rossiter, comp., Alexander Hamilton, James Madison, and John Jay, The Federalist Papers, (New York: Penguin Books, 1961).

12 Leslie H. Gelb, Power Rules: How Common Sense Can Rescue American Foreign Policy (New York: HarperCollins Publishers, 2009). 
begins. For the American republic, the rightful and legitimate "base of power" is not to be found in any particular process or institution, and surely not in any political party; it should never be allowed to be found in anything other than the people themselves - the General Will.

- "Power shrinks when it is wielded poorly." Failed or open-ended wars diminish power. Threats and unrealistic promises left unfulfilled diminish power. Mistakes and continual changing of course can also diminish power.

Lastly, but perhaps most importantly, it is important to appreciate the Founders' and Framers' original intent for the source pool and main sanctuary of American power-the law; and importantly, not a sanctuary found in rule by law, but rather in rule of law.

During the first decade of the twenty-first century, and now closing on half-way into its second decade, military force has occupied a central place in American foreign policy as the nation has confronted new threats, opportunities, and responsibilities resulting from globalization and other geopolitical shifts in the international environment. Questions about whether and how to intervene militarily have become more important than ever.

Since the end of the Cold War, and certainly since the shock of 9/11, the United States has found itself faced with a "Goldilocks" dilemma. It had to find that "just-right," or rather, that ethically just and legally right, answer to the operational questions of the day-that is, how to project and exercise military power in a manner that is effective, but just and lawful. It is at the heart of this goldilocks challenge where questions of American power versus force lie.

The post-Cold War period has proven to be a period of widespread ethnic-religious, cultural conflict that neither states nor nonstate actors have been able to contain. Since $9 / 11$, the international community has had to confront the rise of transnational terrorists. It has also been challenged to accommodate developing norms and obligations related to such things as human security, self-determination, and human rights.

US military interventions since 1989 have fostered tectonic changes in the international system. They have challenged traditional norms, principles, rules, and decisionmaking procedures that have provided stability to the system for the past sixty years. In particular, US interventions have challenged what was once considered largely inviolable-territorial sovereignty.

While the 1990s witnessed the beginnings of a decline in interstate wars, there has been a rise in internal conflicts, and, importantly, an increase in the internationalization of these internal conflicts. In fact, the defining feature of many of the military interventions of the 1990s - Somalia, the Balkans, Haiti, Rwanda, Kosovo, East Timor, and others-has been the rising call and drive for foreign interventions aimed against sovereign states on behalf of citizens and communities within those states.

Thus, the inviolability of state territorial sovereignty has unraveled, in part through a combination of changes in the international security system, but also at the hands of interveners among whom the United States has been and continues to be a lead participant. 


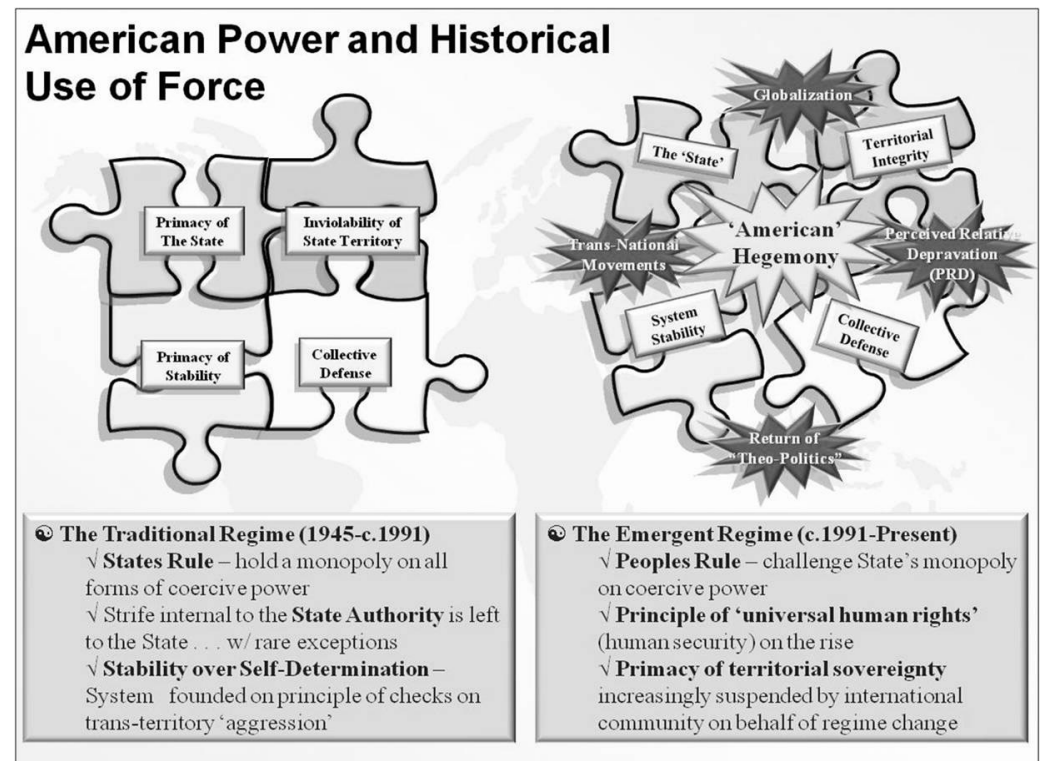

Figure. The Paradox of American Power

Indeed, it has become apparent that the United States has had a profound effect on the destabilization of the international system and that it has challenged the traditional legal and normative international regimes that have defined the obligations - and limits - of right and just intervention, and the limited and precision uses of force as one (but not the only) application of American power, for a half century. The power dilemma facing the United States and the international community today is one of a goldilocks story line-it involves reconciling these new justifications for intervention with the traditional norms that focused on checking territorial aggressions by asserting near-absolute state sovereignty.

In an earlier age, "island nations" like Great Britain (and to a lesser degree, the United States) could build-down, even decimate, their peacetime armies with impunity, as intervention was typically limited to redressing violations of a sovereign state's territory by an aggressor and a restoration of status quo ante-bellum. But since the 1990s, the global security environment demands more from its great powers and especially its leading state. Today's interventions, to be considered right and just, must establish a better state of peace post-bellum. ${ }^{13}$ The prevailing norm of universal human rights, once confined to the Hague and Geneva Conventions, increasingly assumes the more demanding form of a Responsibility to Protect capable of triggering (or at least justifying) uses of military force for humanitarian purposes by an ever-growing

13 Jus post bellum ("justice after war") obligations are on the rise, and have been for the past two decades as evidenced by the emergence of new, albeit still uncodified conventions obligating foreign intervention forces to not only wage just interventions, justly, but also to stay the intervention "beyond the warfight" as occupier on behalf of assisting in the establishment of a new social-political governance — regime rebuilding. See Rear Admiral Louis V. Iasiello, Chaplain Corps, U.S. Navy, "JUS POST BELLUM: The Moral Responsibilities of Victors in War," Naval War College Review 57, no. 3/4 (Summer/Autumn 2004): 33-52, http://www.usnwc.edu/getattachment/022caef3-60c8-4caa-9153bd08f28387d5/Jus-Post-Bellum--The-Moral-Responsibilities-of-Vic.aspx 
number of nation-states. The internationalization of internal conflicts, oftentimes pitting one or more nation-states against roguish regimes making national claims of self-determination, adds yet another illdefined but common causus belli. ${ }^{14}$ A sustainable security strategy in this day and age must be based on a provision of force and a doctrine for guiding its application capable of attaining "viable peace." ${ }^{15}$ A sustainable security posture depends on marrying the right capabilities with the right strategic goals (balance) and a capacity for mobilizing and sustaining force that can achieve economies of scale in international interventions (durability). The ability to marry so-called hard and soft power in effective-cost and legitimate ways is the supreme test of security strategy making.

This has not, however, been the United States' favored mode of intervention. Instead, the history of American intervention reveals an inclination to using martial instruments to cure what are, essentially, political dilemmas. The flexibility and projectability of the US military instrument has secured its prominence in the minds of American strategists, and yet the American record in unconventional interventions ("dirty little wars") has actually been quite dismal. This is especially so when the United States has found itself an external patron to the counterinsurgent in intrastate wars and military-humanitarian interventions. Many of the United States' experiences in these types of interventions have ended in stalemates or incomplete finishes. ${ }^{16}$ The Vietnam War was a complete war-loss for the United States; it is perhaps too early to tell how Afghanistan and Iraq will be remembered, but the trends do not give much reason to hope these interventions will free the United States from its historical trend. These interventions began well enough, but like a boxer replete with years of bout experience and a reach that outdistances younger, less-experienced competitors, the United States is left facing this tale of the tape: "great reach, but poor endurance in the latter rounds."

Part of the problem is simply not having enough physical capacity to meet global requirements, but this problem is not easy to address. If ours is a "not enough boots on the ground" problem, then one simple answer might be to limit the ground on which we send our available boots. We might at the very least resolve not to occupy more ground, as then-Secretary of Defense Robert Gates put it when he said that "any future defense secretary who advises the president to again send a big American land army into Asia or into the Middle East or Africa should

14 Isaiah Wilson III, "Dueling Regimes: The Means-Ends Dilemma of Multilateral Intervention Policy," World Affairs, January 2001.

15 A definition of "sustainable security" commensurate to the conditions of the 21 st century operating environment expands beyond traditional physical and material-based concepts of security, i.e., beyond those forms of security typically achievable and sustainable by military power alone. Today's wider concept of "security" and the threats to it include, but are not limited to, issues of human security (and the provision of basic essential needs), cultural security, economic security, and environmental security. For a full description, see "Promoting Sustainable Security," NDC Occasional Paper No. 12, NATO Defense College, Research Branch, Rome, February 2006, and also the research by the Fund for Peace. For a definition of "viable peace," see Jock Covey, Michael J. Dziedzic, and Leonard R. Hawley, eds., The Quest for Viable Peace: International Intervention and Strategies for Conflict Transformation (Washington, DC: United States Institute of Peace Press, 2005),

16 Jason Lyall and Isaiah Wilson III, "Rage Against the Machines: Explaining Outcomes in Counterinsurgency Wars," International Organization 63 (Winter 2009): 67-106. 
'have his head examined."'17 We might also get rid of ground currently occupied.

Neither option, however, is feasible in today's environment. The ground and the threats on it, after all, "get a vote," and they sometimes demand an American presence even when Americans would prefer to be elsewhere. While we might wish to withdraw from some of the nearly 130 countries where we perform a variety of intervention tasks ranging from traditional combat to peace operations, to do so would likely destabilize the world even more than our occasional missteps do. ${ }^{18}$

Alternatively, the United States might acquire more boots. We have long known the number of troops necessary for waging and winning unconventional interventions. To defeat the violence of an insurgency, a precondition for stabilization and reconstruction operations, we know that it takes approximately one rifleman for every twenty insurgents. For stability and reconstruction, approximately fifty soldiers are needed for every one person in the population. These forces would be a multicomposition force bringing a wide variety of skills and knowledge to this side of the counterinsurgency campaign, ranging from skills in major combat operations to city and regional planning expertise. Finally, we should not discount perhaps the most important lesson of all regarding war . . . while it is vitally essential to first determine the kind of war a nation is embarking upon (the supreme Clausewitzian warning), sometimes particular kinds of wars may embark themselves on a nation-state, or community of nation-states. Put more simply, sometimes war is less a matter of strategic choice and more an unavoidable issue of moral imperative.

Not having the appropriate quantities of force (simple overstretch) is bad enough; attempts to stretch that ill-fitting set of capabilities over and onto a problem set well beyond the traditional military uses of force (compound overstretch) can foster the illiberal practices that make American intervention seem an exercise in imperialism. There is, of course, a point of diminishing return that all great power nation-states (and empires) must come to face as they attempt to expand or merely to maintain their global status.

"Nations project their military power according to their economic resources and in defense of their broad economic interests," Paul Kennedy has argued. "But, the cost of projecting that military power is more than even the largest economies can afford indefinitely, especially when new technologies and new centers of production shift economic power away from established Great Powers - hence the rise and fall of nations." 19 The mechanism that seems to lead a nation-state from liberal towards more imperial forms of intervention is military force itself, and

17 Tom Shanker, "Warning Against Wars Like Iraq and Afghanistan," The New York Times, February 25, 2011.

18 On troop deployments, see GlobalSecurity.org, at http://www.globalsecurity.org/military/ ops/global-deployments.htm. I have focused on the inadequacy of current military force posture from a "landpower" (US Army) standpoint for two main reasons: (1) lack of space to discuss Total Force shortfalls and (2) the nature of the 21 st century security dilemma is namely a landpower and littorals challenge- ours is an incapacity to sustain force on ground we need to hold to build viable peace and stability for the duration of the intervention. This task is largely and predominantly a core Army function, and consequently from a military standpoint, a landpower shortfall.

19 Paul Kennedy, The Rise and Fall of the Great Powers (New York: Vintage Press, 1989), Introduction. 
particularly the manner in which it is used. For the Roman Empire, it was the legions - the institution of last resort - that, in their efforts to secure Rome and her empire by means of increasingly authoritarian uses of coercive force, contributed to her decline. Great care must be taken to ensure that the actions our own "legions" take in defense of liberalism do not have the unintended effect of fostering illiberalism.

To turn to our technological preeminence for solutions to vexing human problems of this sort is to confuse the fruit of our success with the cause of it. We do not enjoy power because of our advanced technology; we enjoy advanced technology because of our power.

In summary, it is important, essential, that the United States now reconsider its understandings of power and its uses of force for at least two reasons. First, the United States must, as a nation, recognize that it is, in and of itself, a system effect. ${ }^{20}$ For better or worse, or perhaps mixes of both, and particularly since its "last great power standing" rise to global hegemony in the wake of World War II, the choices the United States makes in where and how it intervenes (including those choices of where not to intervene) are not merely US choices, but choices that impact the entire world-system. ${ }^{21}$ Having a deep and accurate understanding of and appreciation for differences between force and power is critical to liberal, legitimate, and instrumentally effective global leadership; mistaking uses of force, "forcefully," for power is a recipe for accelerated decline of America as a great power, with destabilizing consequences for long-term global stability, security, and prosperity.

Secondly, more difficult but equally important, we must take account of the implications of our own roles and responsibilities, of our policy choices and actions, into our Power calculations. The United States has had a heavy hand in infusing the current international system with much of its current instability - this, in spite of the noble goals and intentions behind those policy decisions and uses of force. The internationalization of otherwise internal conflicts, military-humanitarian operations, counterinsurgency, democratization, and preventive war-all uses of American military force that have had destabilizing effects on the stability of state regimes, national ethno-sectarian balances, and stability of the international system in general. We as a nation and global leading power must become a better study of the quality of peace that we promise through our acts of wars, those of short and long duration. We must calculate the power consequences of the peace we ring in through uses of force.

\section{Renewing American Grand Strategy}

Confronting a punishing budget crisis, an exhausted military, reluctant allies, and a public whose appetite for global engagement is waning, the United States faces an intertwined set of critical questions. Among these questions, three stand out:

- How will current political realities affect the range of strategic choices

20 Robert Jervis, System Effects: Complexity in Political and Social Life (Princeton, NJ: Princeton University Press, 1998).

21 Immanuel Wallerstein, The Modern World System: Capitalist Agriculture and the Origins of the European World Economy in the Sixteenth Century (New York: Academic Press, 1974). 
available to policymakers?

- How can the United States government make the best possible strategic choices?

- What role will the existing tapestry of US relationships and regional partnerships play?

All of these are political questions. When resources become scarce, the politics surrounding budget decisions escalate. All of these are also military questions. In the final hours of last-ditch discussions to avoid the February 2013 sequester, Joint Chiefs Chairman General Martin Dempsey summarized the military aspect of budget battles with bracing clarity. "What do you want your military to do?" General Dempsey asked in testimony to the House of Representatives. "If you want it to be doing what it's doing today, then we can't give you another dollar. If you want us to do something less than that, we're all there with you and we'll figure it out." ${ }^{22}$ All of these are, finally, questions of grand strategy; they involve the calculated relation of means to large ends. ${ }^{23} \mathrm{On}$ this plane, the fundamental challenge facing the United States might be put this way: After sixty-five years of pursuing a globally engaged grand strategy - nearly a third of which transpired without a great peer power rival-has the time finally come for retrenchment? ${ }^{24}$ Or can the United States discover a way to navigate uncertainty while preserving American dominance as a leading power in and of the international system? These questions will be at the core of our political debates in the years to come.

US strategists need to think of power, to whatever purpose it is put, in relative rather than in absolute terms. The key to their success is the ability to gain the most from their capabilities while their adversaries do not. US strategists also must understand the difference between the power to win battles and the power to win wars. Winning battles is important, but the battles have to count toward winning wars. Understanding which ones do and which ones do not is a purely intellectual exercise.

A renewed American grand strategy would acknowledge the nation's tragic flaw: its pride in its force and technology. It would also acknowledge the proximity of this flaw to the nation's virtue: the set of principles and institutions for restraining force that have proven uniquely adept at producing abundant prosperity, force, and with them unsurpassed power. And it would, finally, exorcise, or at least contain, the ghost that has haunted American intervention by casting war as a matter of mere force rather than an instrument of policy.

As they prepare for this spiritual struggle, American grand strategists might recall that not all ghosts are "goblins damn'd," as Hamlet worried the ghost of his father might be; they are just as frequently "spirits of health," returning to remind the living of first principles and restore their sense of duty. We should exorcise our goblins while welcoming the spiritual remnants of times when American power prevailed even in the absence of preponderant force.

22 Claudette Roulo, “Chairman Outlines Sequestration's Dangers," American Forces Press Service, February 13, 2013.

23 John Lewis Gaddis, "What is Grand Strategy?" lecture delivered at Duke University, February 26, 2009, http://tiss.sanford.duke.edu/DebatingGrandStrategyDetails.php.

24 Stephen G. Brooks, G. John Ikenberry, and William C. Wohlforth, "Don't Come Home, America" International Security 37, no. 3 (Winter 2012/13): 7-51. 
The great challenges and opportunities that lie before the statesmen of the United States lie in questions of American Power. Power is about choices-choices over how to generate force, in different quantities and of different qualities; whether we choose to generate force on our own or in genuine partnership with others. Again, a reflection on the Monroe Doctrine and the American approach to power versus force is instructive to us now and going forward. The Doctrine was issued at a time when nearly all Latin American colonies of Spain and Portugal had achieved independence from the Spanish Empire and the Portuguese Empire. The United States, working in agreement with Britain, wanted to guarantee that no European power would move in. It was actually mainly through partnership with Great Britain that the United States was able to make credible, with the presence of British military force, the deterrent threat of Monroe. In short, what we see at the time of Monroe, and in the Doctrine itself, is a grand expression of American power (according to most scholars on the subject, one of the grandest expressions of US power in the country's history) at a time when American force was relatively anemic. This power-force paradox offers the United States great and important lessons for the gathering and learning as America's capacities to generate and sustain force inevitably continue and decline while its global leader responsibilities increase and become more complex. As Sir Isaac Newton taught us centuries ago, the bigger determinant over the strength and direction of power is found in how we displace force over time. Displacement of force, or rather, how we as a nation choose to use our force, and the manner of behavior behind our uses of that force, or rather, how we as a nation choose to use our force, and the manner of behavior behind our uses of that force, independently and in collective actions with others, is a strong determinant of power, just and rightful power, legitimate power.

Austerity in terms of dwindling dollars and cents does nothing to deny citizens nor elected leaders in making these power choices. Only a self-imposed austerity of sense and sensibility can deny a great nation like the United States of all the opportunity that "rides on the dangerous winds" of future times ahead and are, undeniably, ambiguous and ripe with crisis.

As in past times, why and how America intervenes will matter. 


\title{
Redirecting US Diplomacy
}

\author{
James Goodby and Kenneth Weisbrode \\ (C) 2013 James Goodby and Kenneth Weisbrode
}

\begin{abstract}
AвSTRACT: The international system of nation-states is evolving into something more complex and indeterminate. One important development has been the creation of regional communities. If these are to thrive in their own distinctive way, national governments, including the United States, will need to support creative policies that harmonize interests, not only within such communities but also among them. Policy planners, therefore, must think globally and act regionally.
\end{abstract}

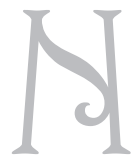

ot so long ago, "international relations" meant "inter-state relations." Issues of war and peace belonged exclusively to the governments of states. They ruled the world. This was commonly called "the Westphalian system," after the 1648 Peace of Westphalia, which dictated the principle of independent national sovereignty and laid the geopolitical foundation for the next several centuries.

It replaced a more decentralized system that was much like the system now emerging in this age of transition. The Westphalian system has given way to one in which the dominance of nation-states is challenged by global and regional entities, as well as subnational ones. ${ }^{1}$ National governments no longer have a monopoly over the use of force on a large scale and, hence, over decisions concerning war or peace. Their power is seeping away.

Fragmentation, or disintegration, appears to be the inevitable "other side of the coin" from the integration inherent in the process of globalization. The reasons for this are not altogether clear. Perhaps the disintegration has occurred because power has been reallocated within the international system. Perhaps global institutions seem too remote. Certainly, the export of jobs and competition with workers in distant countries breed reactions leading to barriers between nations.

Probably a mix of all these factors has contributed to this reaction, and we might reasonably invoke the philosophy of Hegel to suggest that a new system of governance will be a synthesis of globalization and localization. In any case, arguably, all of the conflict and turmoil that has affected the Euro-Atlantic region since the end of the Cold War, perhaps even the end of the Cold War itself, has resulted from the ambitions of actors operating below the level of states. Ethnic cleansing, the rise of political Islam, the dissolution of multinational states, over-reaching by financial organizations - all these are evidences of fragmentation. The correlation with the successes of globalization during this same period is too strong to ignore.

National governments are fighting to retain their authority but it appears to be a losing battle. The technologies and tools they deploy to preserve their share of power also undermine it, as individuals and networks have become empowered by information technology. Barriers

1 Rodrigo Tavares, "Foreign Policy Goes Local," Foreign Affairs, October 9, 2013. 
to trade only serve to weaken that power further. The process of creating new forms of governance continues unabated, but in a more or less haphazard fashion.

This development does not mean that nation-states are going away or that their powers are permanently lost. In fact, one of the striking things about the history of nation-states is not merely how enduring they have been, but also how successful most have been in adapting to new geopolitical and economic conditions.

\section{A European Example}

The archetype of cooperation is still the "European project," despite its many internal tensions. In Europe, a true security community has been constructed, where its members never entertain the thought of war among themselves. But even in Europe, nation-states survive and in a few cases appear to thrive. The half-century of European integration has served them well. To use the language of one of contemporary Europe's best known historians, the late Alan Milward, supranationalism has served to rescue the nation-state. ${ }^{2}$ This verdict is not universally held but nation-states do coexist with other structures designed both to limit and to extend their power.

Nation-states today matter more for what they do than what they represent. We need to focus less on whether or not they may cease to represent large communities and more on how they behave toward one another, and toward their own citizens.

So long as nation-states exist, so will nationalism. The transition of a system based on one form of national behavior into another is bound to generate conflict, particularly of the old-fashioned nationalist variety. How best can national governments mitigate it? For Americans in particular, the rule of law, backed by global institutions like the United Nations, was the stock answer.

For many nations, it still is the correct answer. And yet global institutions have had limited success in dealing with regional conflicts. For those conflicts, which are the main threats to global peace today, a region-based approach is essential. Indeed, regionalism has emerged as the preferred way in which the middle powers of the world have elected to pool their sovereignty. This approach sustains the viability of the nation-state and reduces the appeal of nationalism. It grants those activities with the most disruptive potential, like economic competition, a stake in a positive process of change.

Cooperation at the global level remains difficult to achieve. Many believe that this transition has gone into reverse. The Wikileaks and National Security Agency revelations suggest that national governments are busy retaking control of the global environment with the tools previously used to diffuse power away from them. There are rumblings throughout the world of a new round of protectionism, trade barriers and the like. The Economist recently proclaimed the emergence of a "gated globalization."3

2 Alan S. Milward, The European Rescue of the Nation State (London: Routledge,1992).

3 Greg Ip, "The Gated Globe," The Economist, October 12, 2013. 
Technology is continuing to change our world, particularly the relationship between government and its people. Private organizations are the main generators of this change, not governments, and governments are dependent on them, just as monarchs were dependent on the grand seigneurs in pre-Westphalian times.

Surprisingly, the emerging order begins to resemble the tiered system of medieval Europe, with an overarching layer of global institutions exercising some normative influences and a number of local power centers, including nation-states, highly dependent on their ability to mobilize private, very powerful economic organizations. It is a structure in which loyalties easily become divided and diffused.

The most effective structural change that could be injected by nation-states into the new forms of governance would be a renewed emphasis on regionalism. Europe may not be the model that nations elsewhere will want to follow, but other, simpler, models already have emerged-North America, Southeast Asia, and perhaps Africa and Latin America, among them. Policies that encourage the further evolution of these models would be on the right side of history.

Good governance will demand that regional communities not act as blocs, shutting out one another's members or allowing others to fall through the cracks. Regional communities will only work over the long term if they consistently promote both intra- and inter-regional cohesion. Their paths to regionalism must be their own, but for outsiders it means placing an explicitly higher priority on regional policies-and regional sensibilities — over clearly global ones.

\section{US Influence and Regional Affairs}

American interests and policies loom large in every regional setting. This is true closest to home. It is seldom mentioned how potentially powerful North America has become. In an article that appeared in The Wall Street Journal last summer, former Secretary of State George Shultz remarked on the integration of the economies of the United States, Canada, and Mexico:

The three countries constitute around one-fourth of global GDP, and they have become each other's largest trading partners. A 2010 NBER study shows that $24.7 \%$ of imports from Canada were U.S. value-added, and $39.8 \%$ of U.S. imports from Mexico were U.S. value-added. (By contrast, the U.S. value-added in imports from China was only $4.2 \%$.). This phenomenon of tight integration of trade stands apart from other major trading blocks including the European Union or East Asian economies. ${ }^{4}$

A cohesive North America thus can exert a strong influence on global trade and the strengthening of liberal institutions. "North America, with the U.S. in the lead, is the world's center of creativity and innovation," Shultz continues, "Any measure will do: new companies formed, Nobel Prizes received, R\&D spending, attractiveness to high talent from anywhere, patents issued, and numbers of great universities." ${ }^{5}$ This all may result someday in the beacon of a world's most successful regional community, where armed frontiers are transformed into pros-

4 George P. Shultz, "The North American Global Powerhouse," The Wall Street Journal, July $11,2013$.

5 Ibid. 
perous borderlands, and where economic power and political influence go hand in hand.

This moment is still a long way off. But contrast it to where North America was just a couple of decades ago before the North American Free Trade Agreement (NAFTA). A logic of regional peace has appeared in other regions meanwhile. Whether by design or by default, diplomacy, specifically American diplomacy, has begun to resemble the kind of cautious, step-by-step path of constructing better neighborhoods without the obvious need for bigger fences. Some developments elsewhere include:

- The Middle East. The Obama administration reportedly is trying to be less hamstrung in the unending struggles there but it is unlikely to succeed, if only because it already is engaged in reinvigorating talks between the Israelis and the Palestinians; has worked with Russia to find a way to contain and eventually to reverse the course of the Syrian civil war; and has been blamed - rightly or wrongly — for exacerbating recent turmoil in Egypt and elsewhere in the region. ${ }^{6}$ Meanwhile it has forged ahead in helping to reverse the threat posed by Iran's nuclear ambitions by exploring ways to reassure both Iran and its neighbors that a Middle Eastern nuclear arms race is neither desirable nor inevitable.

- Central and South Asia. The administration has sought to reestablish a more normal relationship with Pakistan as North Atlantic Treaty Organization (NATO) troops withdraw from Afghanistan, although this is proving very difficult. ${ }^{7}$ Economic ties between India and Pakistan, which the United States supports, are the best hope for ending the risk of war between these two key nations. Regional cooperation that includes Afghanistan may also become a possibility, particularly now that Afghanistan's northern neighbors, the former Soviet republics of Central Asia, are desperate for investment and access to markets following the removal of NATO largesse from their backyard.

- East Asia. The administration has worked with China to stop the cycle of crises coming from North Korea and is seeking multilateral solutions to territorial disputes nearby. A regional organization for security and cooperation in Northeast Asia may become part of a political settlement there.

- The World Trade Organization. As the WTO is stymied in further trade liberalization, the administration has launched the two largest trade negotiations since the collapse of the Doha Round: a transpacific and a transatlantic free trade area. Some have called this a new backdoor method to global trade, but it promises to be much more than that if negotiations, admittedly very difficult, someday succeed. ${ }^{8}$

Most of these policies are in harmony with the systemic transition underway which is dispersing power to global, regional, and local groups,

6 Edmund Sanders, "Anti-Americanism Flares in Egypt as Protests Rage Over Morsi's Ouster," Los Angeles Times, July 6, 2013.

7 Shuja Nawaz, "A New Honeymoon for the United States and Pakistan?" New Atlanticist, November 1, 2013.

8 Ana Palacio, “The Regional Route to Global Free Trade," Project Syndicate, August 1, 2013. 
and empowering them with access to information that was never shared with them in the past.

But what this diplomacy also shows is that preventing conflict is more the task of regional interaction rather than of globalization per se. It has taken too long for it to sink in that while globalization by definition has spread around the world, it affects different places very differently and, in some, strengthens rather than diminishes the draw of nationalism. For the United States, still the world's most powerful nation-state, this reality calls out for recognition and action.

\section{The Continuities of Policy}

In the spring of 2000, we wrote an article called "Back to Basics: US Foreign Policy for the Coming Decade," in which we sought to define US strategic interests, beginning with the proposition that the nation's main foreign policy goals were the success of globalization and of democracy, but that its means for achieving these goals were unfocused. ${ }^{9}$ We spoke of methods for managing regional interests as an important way to bring better focus to them.

US policy still is unfocused. President Obama has not embedded his regional initiatives in an explicit long-term strategy that is in tune with historical change. Currently, they are seen simply as a set of disjointed actions that respond haphazardly to local problems, offering headlines for "trend lines," as President Clinton liked to say.

Obama's response lacks any connective tissue and so it looks pretty meager, especially in regional forums. The president has attended few European Union summits and has never gone to an African Union summit. The only region where some sort of long-term strategy can be discerned in the administration's rhetoric is in the repositioning to Asia, but this has mainly been part of an ill-disguised effort to balance China's rise, rather than the recognition of the benefits that concerts of nations can bring to a world in transition.

Aside from embedding US regional diplomacy in a unified coherent strategy for peace, a better approach calls for finding and exploiting near-term regional opportunities. In the two trade negotiations, for example, large global powers like the United States may need to adjust more than they otherwise would to the necessities of smaller, regional states with incomparably more at stake. Or, in the Middle East and Northeast Asia, it could involve devising a common security language and a code of regional conduct while encouraging people in these places to apply them to their own affairs as they see fit, especially as the US military presence around the world continues to ebb.

This approach would fit well an old American diplomatic tradition but one that has gone relatively unrecognized. The genius of the Marshall Plan, for example, was not so much its generosity toward starving Europeans in 1947 or its self-interest in building prosperous new markets for American goods and investment. It was both these things. But most of all, it was a grand political gesture which said to Europeans, if you agree to work together from now on, we are prepared to help you,

9 James E. Goodby and Kenneth Weisbrode, "Back to Basics: US Foreign Policy for the Coming Decade," Parameters 30, no. 1 (Spring 2000): 51-56. 
but we shall not dictate the precise terms of your cooperation beyond insisting that you do, somehow, cooperate in our mutual benefit.

Cooperate is in fact what the Western Europeans subsequently did. They took some advice from the Marshall Planners but not all of it. They pursued their own path toward a regional community, through many fits and starts and reversals, on their own terms but also in consultation and collaboration (and occasional contestation) with outside backers, namely the United States. Regional autonomy is not the same thing as autarky, just as regionalism, internationalism, and globalism need not necessarily be mutually exclusive orientations or recipes for economic and political change.

Proposals to replicate the Marshall Plan model elsewhere have long been abundant; however, few have emphasized its basic principle of regional self-help. This principle has the potential to construct more peaceful and prosperous neighborhoods; however, its main effect is representational: that is, to show that even long-established rivals sitting side by side can transform their enmities into patterns of cooperation whose value is much greater than the sum of their parts. This realization need not mean sacrificing every national source of power and influence in the process, but does require a demonstrable sharing of power among nations and regions.

The process has no hidden hand or honest broker, however much the United States has cast itself in that role in the past. It takes continuous and difficult negotiation, and, most of all, public understanding and support.

Obama's first major achievement has been to convince a good number of his fellow Americans that the United States is a part of the world and has an obligation to listen more often. His next achievement, if the various negotiations succeed, would be to help set in motion workable processes of regional peace so that the United States itself can be at peace and prosper, both at home and abroad. It would mark an important step forward in the remaking of a weary superpower into a credible great power.

Power itself has changed. So have the means for wielding it. Today we repeat this almost as a mantra. But the changes have been more gradual and cumulative than most analysts suggest. They do not necessarily represent a clear-cut shift on the commanding heights, or as others would have it, a new permutation of the balance of power among merchants, soldiers, and sages. Something different appears to be taking place. The currency of power has shifted, namely in the ways in which nations collaborate or compete with neighboring nations, and groups within these nations, to maximize their advantages vis-à-vis more distant neighbors.

The major challenge facing our leaders is to fashion a stable but liberal system for accommodating the many interests and passions of this new era while using the leverage they still have, which is considerable. It would be easy to give in to the lowest common denominator and just muddle through. In that direction lays chaos.

Of course, global institutions are essential in terms of pointing the way to a universal system of norms and obligations to support peace 
with justice. But for the rest of this century, an active regional diplomacy, not disengagement, will be the best way to manage the fundamental transformation in the global system now underway.

\section{James E. Goodby}

James E. Goodby is a former United States Ambassador. Currently, he is Distinguished Service Professor Emeritus at Carnegie Mellon University, a Visiting Fellow at Stanford's Hoover Institution, and nonresident Senior Fellow at The Brookings Institution.

\section{Kenneth Weisbrode}

Kenneth Weisbrode is a writer and historian currently working at Bilkent University in Ankara, Turkey. 



\section{Rebalancing US Military Power}

\section{Anna Simons}

(C) 2013 Anna Simons

\begin{abstract}
For all the attention paid to partnering, too little goes into what "partnering" might mean from ostensible partners' points of view. In the 21 st century, sensitivities and sensibilities matter. So do economic realities. The US military should make better strategic use of military advisors to help foreign security services professionalize- something the United States can only do if foreign militaries are willing to engage in civic action themselves.
\end{abstract}

$\mathrm{n}$ the wake of resurgent terrorism, withdrawals from Iraq and Afghanistan, and massive budget cuts, defense intellectuals and members of the military alike increasingly discuss the need to shape, partner, and advise foreign forces. ${ }^{1}$ Or, as LTG Charles Cleveland and LTC Stuart Faris write, "America's land forces should look to develop a global landpower network. This network would consist of allies, expeditionary global and regional partners, and host-nation forces." 2 The goal? To secure US national interests indirectly, inexpensively, and without putting large numbers of "boots on the ground."

White House, too, underscores security sector assistance. Its aim is to:

- Help partner nations build the sustainable capacity to address common security challenges.

- Promote partner support for US interests.

- Promote universal values.

- Strengthen collective security and multinational defense arrangements and organizations. ${ }^{3}$

However, there are at least four flaws in our collective approach.

First, its prescriptions are all about "us" and US-centric needs, thereby taking for granted others' needs. Second, the list reflects little understanding of what "partnering" might mean to America's ostensible partners - in fact, it reveals just the opposite. Third, it suggests the United States will continue to pursue the same old strategies that have already served it so poorly. Finally, it diverts the United States from what should be its main goal abroad: other countries' development of their own incorruptible, apolitical security services-a goal that is an either-or (it can or cannot be done) proposition, and not something, as many suppose, that takes decades to achieve.

1 See Jennifer Morrison Taw, Mission Revolution: The U.S. Military and Stability Operations (New York: Columbia University Press, 2012), for an excellent overview of the promises and pitfalls of stability operations, and debates from various US perspectives.

2 LTG Charles Cleveland and LTC Stuart Faris, "Toward Strategic Landpower," Army, July 2013, 23.

3 The White House, Office of the Press Secretary, Fact Sheet: U.S. Security Sector Assistance Policy, April 5, 2013, http://www.whitehouse.gov/the-press-office/2013/04/05/ fact-sheet-us-security-sector-assistance-policy
Dr. Anna Simons is a Professor of Defense Analysis at the US Naval Postgraduate School, and co-author of The Sovereignty Solution: A Commonsense Approach to Global Security. 
Because some interagency "stakeholders" object to the word "professionalize"-in their view it is demeaning and insulting to suggest other forces are not already professional-in this article, the term "professional" refers to incorruptible, apolitical security services. ${ }^{4}$ The argument is that when security services are incorruptible, states hold together. India is an example. Few countries contain more sectarian divides, or have had to wrestle with a greater variety of insurgency. Yet, India's armed forces have remained apolitical and professional. This is not just a legacy of British imperialism, since other South Asian countries were woven from the same cloth. Rather, India remains a vibrant pluralist democracy thanks to, among other things, the armed forces' commitment to behaving apolitically and according to meritocratic principles. ${ }^{5}$

In contrast, regimes in many countries are not just corrupt, but rulers send members of the security services to do their coercing and compelling for them. Unfortunately, all it takes is the collusion of some high-ranking members of the army, police, gendarmerie, or other security services for leaders to engage in venal behavior. Or, to put none too fine a point on it, whenever people in uniform do politicians' personal bidding and act as their willing muscle, they subvert the state. On the other hand, when members of the security services refuse to engage in intimidation or coercion on behalf of politicians, and refuse to behave like thugs, those in power find it extremely difficult, if not impossible, to compel people against their will.

Security services that protect rather than undermine the state's integrity are not just vital to a country's stability, but apolitical, incorruptible armed forces are also essential to protecting those other two institutions that help guarantee responsible, responsive governance: the judiciary and the media. In fact, try to build any institution of state without first securing the integrity of the armed forces and you will only end up pouring good money after bad-something the United States has been doing abroad for decades. ${ }^{6}$

Meanwhile, professionalization is a straightforward proposition. It does not require a whole-of-government approach — at least not by Americans. It is neither complicated nor costly, although it also is not always possible, to achieve. To gauge whether it is possible requires, first, advisors of the right stature and mindset. Second, general officers in Washington and at the combatant commands have to be willing to take advisors' assessments seriously and convey them truthfully to policymakers.

Americans make a mistake whenever we underestimate the political acuity of non-Western allies and adversaries. ${ }^{7}$ Today, most non-Westerners in positions of authority are more familiar with us than we are with them, a late 20th century inversion that holds profound implications for

4 There is now a vast literature discussing professions and professionalism. See Jessica Groves, Lily McGovern, and Tim Baker, comps., Military Professionalism: An Annotated Bibliography on the Nature and Ethos of the Military Profession (Washington, DC: Institute for National Security, Ethics, and Leadership (INSEL), National Defense University Library, December 2010). http:/ / www.usafa. edu/superintendent/diversityoffice/links/MilitaryProfessionalismBibliography.pdf

5 Of course, the fact that Pakistan and China both loom as real threats has also contributed.

6 For more on the effects of aid, see Anna Simons, Joe McGraw, and Duane Lauchengco, "Chapter 7" in The Sovereignty Solution: A Commonsense Approach to Global Security (Annapolis: Naval Institute Press, 2011).

7 For the full argument, see Anna Simons, 21st Century Cultures of War: Advantage Them (FPRI e-book, 2012). https://www.fpri.org/docs/Simons_21st_Century_Cultures_of_War.pdf 
advising and partnering in the 21 st century. ${ }^{8}$ Indeed, those who think a 10 - or 20,000 person advisory corps, or partnering as we conceive it, are suitable counters to terrorism or insurgency display little more their own unsophistication about the non-West. Forget, too, T. E. Lawrence as a role model-his methods remain shrouded in controversy. What stability and security require instead is working by, with, and through professionalized security services.

\section{Advising}

Consider the history of successful military advising-with success defined as both parties getting what they need out of the relationshipand it should quickly become apparent that mass-producing advisory skills is a contradiction in terms. ' Interpersonal chemistry matters. So do attributes like humor, patience, wile, and the ability to influence without manipulation. There is no evidence that any of these are trainable skills, or that such traits are as common as most proponents of advising missions seem to think. Instead, their combination is rather rare.

The history of successful military advising shows a distinct arc, one that coincides better with the shift in who understands what about whom. This arc is perhaps best described using the default lens of familial relations. Parent-child, sibling, and spousal relations can be considered default relations not only because they are the relations most familiar to most people, but because they also comprise the basic bio-grammar for how we humans interact. ${ }^{10}$

In parent-child relations, parents dominate and typically command respect. As children age, authority may chafe and youth might eventually rebel, but fealty should endure.

When it comes to siblings, older brothers and sisters are in a position of literal (if not figurative) dominance, at least initially. As younger siblings mature, they often attempt to escape their elders' thumb or shadow, and what had been respect can turn to resentment. Over time, younger siblings usually expect to be treated as equals, though they never will be equals from their elders' perspective.

Meanwhile, in healthy marriages, spouses are co-equals despite, if not because of, their differences. Couples share a division of labor (even if unevenly), and though one spouse will doubtless be better at certain things, and will likely dominate in certain areas, in stable marriages neither individual will be judged as superior in all things.

8 This is a literal truism if one just considers the number of heads of state who speak English and at least one other language vs. their American counterparts.

9 Not even everyone in the US Army Special Forces (SF) is suited to be a military advisor, though SF selection comes closer than any other to screening individuals with advisor-like skills. I write this based on extensive discussions over the past 15 years in my Military Advisor class, as well as field observations in Iraq and Afghanistan. At the same time, I need to be clear: a 10,000-person corps might well be capable of training foreign forces. But training is to a standard, and is far easier for young marines, soldiers, and others to accomplish than is advising, which requires contextdependent judgment.

10 I am borrowing and stretching Lionel Tiger and Robin Fox's notion of bio-grammar from The Imperial Animal (New York: Holt, Rinehart, and Winston, 1971). Or, as Edward Schein notes, "As Freud pointed out long ago, one of the models we bring to any new group situation is our own model of family, the group in which we spent most of our early life," Organizational Culture and Leadership, 3rd ed. (New York: Jossey-Bass, 2004),124. 
Advisory relationships often bear a resemblance to one, two, or arc across all three, of those categories, and can morph or evolve (and even devolve) over time. For instance, American advisors in the jungles of World War II actually led more often than they advised, but by Vietnam they commanded less and worked with the "indig" more. In contrast, few populations today are unfamiliar with Western influences. Advisees tend to expect reciprocity at a minimum.

Two obvious points are worth drawing here. First, both parties in a relationship will not necessarily view it similarly. And expectations will differ cross-culturally. For instance, while marriages in the West tend to be marriages of choice, officers from Jordan and Pakistan have pointed out how similar advisory relations are to arranged marriages; most advisors and advisees have no choice about who they are partnered with and have to learn how to accommodate one another if they want the partnership to work. ${ }^{11}$

Thanks to the culturally specific ways humans have been raised to treat those who remind them of parents, siblings, or spouses, there is a strong likelihood that counterparts without deep cross-cultural familiarity will misread one another, to include misreading one another's misreadings. ${ }^{12}$ Alternatively, too much time spent together can pose different problems. For instance, sometimes when people know each other too well they bridle at not receiving the respect they feel they deserve. Two examples would be former allies in Eritrea and Ethiopia or Uganda and Rwanda. Over the course of long liberation struggles, leaders and insurgents in both sets of countries developed sibling-like dependencies, with Eritrea's Isaias Afewerki relying on but also helping to build Meles Zenawi's insurgent forces and Uganda's Youweri Museveni relying on and helping to incubate Fred Rwigyema's and Paul Kagame's Rwandan Patriotic Front (RPF). Years later, both ended up in bitter wars with one another.

While it seems only human that dependence should degenerate into outright hostility on occasion, the real source of the problem with asymmetry is superiority. ${ }^{13}$ It may be impossible for individuals in an advisory role not to regard themselves as superior to those they are advising. Not only does the very fact of having something to impart mean one operates from a position of strength (if not authority), but the more one has to offer and the more deference one receives, the more special treatment one expects.

Another facet of inherent inequality is that treating titular counterparts as equals is easy when they are liked and admired. It feels more hypocritical and corrosive when they are not. But under either

11 In the wake of Saudi Arabia's October 2013 rejection of a UN Security Council seat, consider: "Saudi Foreign Minister Saud al Faisal is fond of saying that the US and Saudi Arabia no longer have a Catholic marriage, but rather a Muslim one. This is a clever way of saying that Saudi Arabia and the US are not faithful to each other. In the absence of any major-power alternative to the US, for the Saudis in this Muslim marriage, the US may well remain Wife No. 1. Even if she is not about to be divorced, however, the Saudis are clearly declaring a trial separation." See Karen Elliott House, "Behind the Saudi-U.S. Breakup," The Wall Street Journal, October 25, 2013.

12 Some Americans might insist that talking in terms of family metaphors is ridiculous; the more useful foil is friendship. They would probably suggest this because, in their view, they always try to treat others as friends. Yet, in doing so they may also fool themselves since their advisees are unlikely to share their understanding of friendship, especially since friendship means something quite different, (and counts for less than family) in many non-Western settings.

13 One actually sees this among social animals across the board, not just among humans. 
circumstance it can be grossly irresponsible to treat people who are not as good as they think they are as though they are as good as they believe, since this can set them-and others - up for failure later. For instance, Lieutenant Colonel John Paul Vann fell into this trap in Vietnam. ${ }^{14}$ He purposely strengthened the reputation of his counterpart, Colonel Huynh Van Cao. By publicly crediting Cao for operations he (Vann) planned, Vann made it impossible to later point out, even to his own chain of command, that Cao was not as effective as advertised. After sounding optimistic about the war for months, Vann never could get higher-ranking officials to heed his reassessment of the conflict. Of course, cynics might contend that Vann's approach is simply emblematic of what happens whenever wars are subjectively recounted.

Looking ahead, it will not just be rhetorical excess that plagues reporting (and analysis). Among the challenges confronting members of the US military is to assess how best to work with forces whose sensibilities about their capabilities may well outstrip their actual abilities, but who are also hyper-sensitive to any slights. This brings us to the term "partner." Tellingly, few in Washington have spent sufficient time examining what the word "partner" might mean from current or likely future partners' points of view. Washington has not made clear what partnership should mean to foreign governments, or to US servicemembers or taxpayers. ${ }^{15}$

\section{Partnering}

Here, then, is one formulation: to succeed, a partnership should be grounded in mutual indispensability. Anything less creates a dependency, and a dependency is by definition not a partnership.

Partnerships can come in a variety of forms:

- In Partnership Type \#1: you are my equal. We are interchangeable, and our forces can be fully blended.

- In Partnership Type \#2: I trust you implicitly. We can agree on a division of labor. I will be responsible for Sectors A, B, and C; you will be responsible for Sectors D, E, and F.

- In Partnership Type \#3: we are complementary and operate in tandem. You have skills and capabilities I lack, and vice versa. I will defer to you for intelligence and local knowledge; you can rely on me for logistics and medevac.

Historically-speaking, the United States has been involved in all three types of arrangements; one can find each exemplified somewhere during World War II. Yet, if one asks how many such arrangements the United States is involved in today, the honest answer would have to be that most of its associations are with expedient dependents.

\footnotetext{
14 Neil Sheehan, A Bright Shining Lie: John Paul Vann and America in Vietnam (New York: Vintage, 1988).

15 Yet, as COL Alan Shumate notes, "building partner capacity is a critical component of our future National Security Strategy. These three words appear twenty-five times in the January 2012 Department of Defense publication, "Sustaining U.S. Global Leadership: Priorities for $21^{\text {st }}$ Century Defense." Alan Shumate, "Building Partner Capacity in the 21st Century: How the U.S. Can Succeed," Small Wars Journal, August 7, 2013.
} 
Nor will Washington's prescription that the US military promote partner support for US interests successfully redress this situation. Just the opposite. Not only does prioritizing American interests put the cart before the horse, it ignores what is needed to keep others' interests and US interests aligned for as long as possible, which has always been the hallmark of successful advising (not to mention partnering). Tackling local needs should always come first. ${ }^{16}$

The reason is simple: as a military becomes more capable of addressing its security concerns, it builds its capabilities to address Washington's concerns - although, ideally, once local forces become sufficiently professional bad actors should no longer operate in (or from) that country. ${ }^{17}$ Of course, professionalization also means members of security services must be paid a decent wage, receive better than decent conditions of service, earn a decent retirement, etc. Tellingly, if fair pay and benefits are not something senior leaders are already striving to secure for their forces, then that is an indicator in and of itself that the security services' culture is awry, and professionalism does not exist.

The inescapable reality, again, is that securing security requires nationally capable — apolitical, incorruptible_-armed forces. Stability is undermined by anything less. So is honest partnership.

\section{Civic Action - The Ultimate Indirect Approach}

One problem with the United States' current approach is that Washington's motivations for working with others are proximate: counterterrorism, counterproliferation, counterdrugs, counter-you-name-it. US forces concentrate on improving local security forces' abilities to shoot, move, and communicate, while also admonishing them to not violate human rights. Washington might hope that these efforts will have additive effects over time, but the truth is nothing the United States does will guarantee stability in someone else's country. That task belongs to them, while the challenge for the United States should be to determine whether its putative counterparts have what it takes before Washington starts investing, rather than after the United States is embroiled.

As for how policymakers might make this determination, consider civic action. It is the ideal canary in the coal mine. Countries that can keep civic action alive are countries with which the US military can work. Countries that cannot, or will not do so, are either beyond US help or not ready for it.

16 Here is one of the kinds of things that can happen when local needs are not met: apparently the US did not realize or did not take seriously the fact that the Malian government's chief concern was separatists, not AQIM. The separatists' ability to operate then created the space for AQIM to move in —and Mali's current plight and spillover effects throughout the region are one consequence: "Over time we began to realize that the ATT government was focused not on AQIM as a threat but rather on Tuaregs in the north," a senior defense official at the Pentagon told me. "He saw a political threat and a security threat but not the kind of counter-terrorism threat that we were focused on. I think that kind of mismatch is part of what was starting to unravel the partnership on [counterterrorism] when the coup happened," Yochi Dreazen, "The New Terrorist Training Ground," The Atlantic, October 2013, 66.

17 What I am suggesting is the obverse of the campaign to get Joseph Kony. The Lord's Resistance Army is not a pressing security concern for any of the African governments involved. Rather, it is of keen interest to certain lobbying groups in the US. That makes it the wrong mission to use for helping depoliticize and uncorrupt regional forces since it is a mission that is more important to President Obama than to local heads of state or their militaries. 
This assertion is based on a two-part comparison. First, there is civic action as conceived by Edward Lansdale, advisor to Ramon Magsaysay, Minister of Defense and then President of the Philippines in the 1950s. Second, is the comparison one can make between Lansdale's approach with what is done today.

Lansdale credits himself with introducing the concept of civic action to Americans during the Huk Rebellion, one of the few 20th century insurgencies the United States succeeded in helping to counter. ${ }^{18}$ According to Lansdale's and Magsaysay's definition, civic action consists of those things a national military can (and should) do to protect rather than prey on its citizens.

In Lansdale's and Magsaysay's view, members of the Philippines armed forces needed to prove themselves to be of, for, and by the people-which meant uniformed personnel had to stop extorting people or accepting bribes. They also had to stop allowing politicians to corrupt them. At the same time, to prove their trustworthiness, there were certain things those in uniform could assist with, such as policing the national elections in 1951. By doing so, soldiers did not just demonstrate their commitment to protect the integrity of the political system, but safeguarded a free and fair vote. Indeed, many say the Philippines has not had as free or fair an election since Magsaysay was tragically killed in a plane accident in 1957.

Two other things noteworthy about Lansdale's advisory approach were that he had very few Americans working with him, and he disbursed very little money. He never bought support. When he did dispense money, it was for doing clever things against the opposition. A third critical factor was, of course, Magsaysay. ${ }^{19}$ Magsaysay was a man of the people. He was also a compelling leader. One example: he loved making surprise visits not only to catch slackards off-guard, but to force the entire military to stay on its toes and self-police, all of which helped (re)instill pride.

In short, both men's version of civic action consisted of the Philippine military proving to citizens its worth as their national (emphasis on the word "national") military. What civic action consisted of and who conducted it was totally Filipino-centric.

Now, compare this to what the United States touts and promotes today. Because Washington likes combining soft approaches and surgical strikes, it engages in development assistance. Yet, no matter how good it makes Americans in uniform feel to build a well here, a clinic there, or a school somewhere else, that kind of unilateral civic action by the United States adds up to nothing coherent in terms of strengthening the social contract or the delivery of goods and services by another government to its people. To be sure, school-building, clinic-construction,

18 William R. Polk, Violent Politics: A History of Insurgency, Terrorism, and Guerrilla Warfare, from the American Revolution to Iraq (New York: HarperCollins, 2007), suggests that William Howard Taft deserves credit for civic action: "unconsciously or at least without attribution, Lansdale took Magsaysay back to the 'civic action' policy of William Howard Taft" (51). For Lansdale's activities, see his own account: Edward Lansdale, In the Midst of Wars: An American's Mission to Southeast Asia (New York: Fordham University Press, 1991).

19 Magsaysay was also noticed because there were Americans who were paying attention. Paying attention and helping create conditions in which talent has a chance to draw attention early are exactly what IMET money and JCET should be doing. 
and well-digging can be important local force protection measures. Whenever a base is put somewhere, those inhabiting it should want people in the neighborhood to think well of them, especially since local residents represent both their first and last local line of defense; the easiest way to get local residents to think well of them is for those outsiders to do things for the locals. ${ }^{20}$ Americans in uniform, however, should not fool themselves. Any such actions they undertake do nothing to improve the capabilities or image of local forces.

Alternatively, where the United States does not maintain a permanent presence, its forces typically support sustainable development instead, a type of assistance that has been fashionable in aid circles for quite some time. Yet, projects that do not require periodic American assistance make little sense for a different reason: after all, if the US government's overarching aim is to guarantee access and placement to counter everything from drugs to weapons of mass destruction (WMD) proliferation, then surely projects that require periodic maintenance, spare parts, technical readjustments, and so on would be more prudent than "fire-and-forget" assistance. One can imagine that if only the military were to treat development projects the way it orchestrates foreign military sales, it would engineer projects specifically designed to need ongoing maintenance, parts, and/or re-fittings-and ideally, maintenance, parts, and/or re-fittings that cannot be reverse engineered or offered by anyone else. Or that, at any rate, is what looking at US strategic interests through a US-centric lens suggests. Flip this lens around, however, and one has to wonder what non-Western government in the 21st century would want, let alone allow, the United States to retain this kind of dependence-inducing leverage over it?

In other words, both approaches are fraught with difficulty. Drive-by well-digging and related practices are of fleeting value other than to help line some locals' pockets, while anything the United States does that is more substantial gets the local government and security forces off the hook of having to provide for and look out for their citizens themselves. Such activities also give the lie to US rhetoric about respecting other countries' sovereignty, since if only Washington took that more seriously, American officials would make it clear to foreign governments that it is their sovereign duty (and not America's job) to develop their countries themselves, using the means at their disposal and not American taxpayer largesse. In fact, Americans contributing anything that can be pocketed, stolen, or skimmed does nothing but undermine sovereignty, and acts as a solvent that both undoes and corrupts local security services.

Any assistance apart from military-to-military training, professional military education, or military exchanges, runs counter to what is needed to secure America's security, which is that other countries secure theirs. As for why militaries and not civilian agencies or nongovernmental organizations (NGOs) should be the lead agent for Lansdalian-style civic action, there are at least three reasons.

1. The greatest need for building mutual trust and confidence between a government and its citizens typically occurs where insecurity has

20 According to population-centric warfare, improving people's lives helps to keep them from succumbing to others' outreach and propaganda. But at least some of what US forces engage in may amount to moral blackmail—but it does (as this author observed in Afghanistan in 2011). 
already been rampant or where there is a history of mistrusting those in uniform.

2. Militaries are designed to operate in austere environments and usually possess greater logistical reach than anyone else; even inept militaries have more equipment and can marshal more manpower than other institutions of state.

3. Militaries are the most nationalist institutions there are, and usually draw from all sectors and segments of society; if they do not they should. This makes them bellwethers, which means they also offer the fastest way for a government to prove to its citizens (and concerned others) that it has turned over a new leaf.

As for why the United States should want to use military-to-military training to support professionalization: this plays to US strengths. Again, too, as Lansdale's and Magsaysay's success makes clear, civic action and professionalization cost very little. Civic action is achieved through local sweat equity, thus it aligns well with 21 st century economic realities. Even better, once Washington makes a country's ability to demonstrate a real civic action orientation the new requirement for receiving security sector assistance, that assistance would no longer have to be substantive, since here would be a government and a military that would already be working toward being self-sustaining, which is the hallmark of professionalism. A country's ability to do its own civic action would also signal it has a military and government the United States can meaningfully partner with and a political economy Americans and others can safely invest in.

\section{Getting from "Advisor" to "Partner"}

By adopting the approach that others need to do their own heavy lifting (while the United States technically assists), Washington would not only free the US military from performing all sorts of aid-like functions but also liberate itself from seeming to preach one thing (equality) while doing something else (infantilizing others). As it is, when the United States helps construct anything-except a civic action capability in another country's military-it creates nothing but new dependencies, which have a sharper edge of resentment than those the Cold War once had.

At the same time, impelling other governments to develop their own civic action capabilities would not just arrest the corruption the United States inevitably funds whenever the Department of Defense undertakes or supports development projects abroad, but there is no better nonkinetic way to compel those in power to remain responsive to their citizens, thus mitigating the grievances that feed rebellion and insurgency.

In this sense, civic action represents a critical capability and litmus test rolled into one. Does the country Washington is considering as a partner already possess a civic action capability? If so, good. If not, is it willing to develop one? Again, governments that do not want their militaries to develop a civic action capability are governments the United States cannot effectively help-nor should it want to.

One of the few silver linings to the past decade's worth of involvement in Afghanistan and Iraq is that most US policymakers appear to 
agree that partnering with a government that shows no interest in its population makes no sense. However, whose responsibility will it be to make this conclusion stick? The obvious answer should be: general officers. Their stars earn flag officers this duty. In addition, no one else is so well positioned to perform (or exert) this responsibility. If advisors determine that a "counterpart" military is not interested, or its government is not interested, in civic action, signaling that professionalization cannot take root, then it should be general officers' responsibility to let policymakers know that, under current conditions, Country X cannot be stabilized or assisted by the United States. On the one hand, general officers should bear this responsibility thanks to their rank. On the other, subordinates and citizens alike depend on them to not play politics. Consequently, general officers have to be prepared to push back hard if the president (who cannot help but be political) insists, since clearly advisors in the field cannot.

Using civic action as a litmus test, and advisors as assessors, is the most parsimonious - and arguably the only foolproof-way to keep the system honest regarding "partners." To forge true partnerships and worthwhile strategic networks requires that partner militaries not only be de-politicized and inoculated against corruption, but that those in uniform reorient themselves toward earning their citizens' trust. Otherwise, it is hard to see how Washington will ever build reliable partnerships to obviate anti-state and nonstate actors that pose transnational threats. ${ }^{21}$

21 For how Washington should interact with states that are not interested in getting rid of transnational threats to the United States, see Anna Simons, Joe McGraw, and Duane Lauchengco, The Sovereignty Solution. 


\section{Is the Law of Armed Conflict Outdated?}

\author{
Sibylle Scheipers \\ (C) 2013 Sibylle Scheipers
}

\begin{abstract}
AвSTRACT: The law of armed conflict has often been described as outdated and ill suited to military conflicts in the twenty-first century. Both academics and practitioners have argued that today's wars tend to be asymmetric conflicts between states and nonstate actors, whereas the law of armed conflict was made with a view to symmetrical interstate war. This article challenges that notion.
\end{abstract}

he law of armed conflict - from the Lieber Code to the Additional Protocols to the Geneva Conventions-was drafted precisely as a response to challenges posed by irregular fighters. The problems with applying the law to irregular warfare stem from two aspects: first, that the drafters of the law repeatedly chose a negative approach to irregular fighters. They neither provided an explicit definition of an irregular fighter nor did they spell out principles for their lawful treatment. The second aspect is that the aims of western military interventions differ considerably from earlier forms of anti-irregular fighting: in today's antiirregular wars, political stabilization and societal reconciliation are the main political objectives. Thus, the central question facing both academics and practitioners is how the law of armed conflict can be applied in a way that furthers these political aims.

The terror attacks of 9/11 and the military operations in their aftermath sparked a debate over the status and applicability of the law of armed conflict in the wars of the twenty-first century. Policymakers on both sides of the Atlantic were quick to assert that the law itself, most of which was drafted during the twentieth century, was inapplicable on the battlefields of the twenty-first century. The argument that the law of armed conflict was ill suited for the new paradigm of what would become known as the War on Terror was decisive for the Bush administration's decision in February 2002 not to apply the Geneva Conventions to al Qaeda and Taliban fighters captured in Afghanistan. ${ }^{1}$ Although most Europeans like to think of themselves as having consistently opted for a rule-of-law approach to terrorism, senior officials in Europe echoed the argument. $^{2}$

1 President's Memorandum for the Vice President, the Secretary of State, the Secretary of Defense, the Attorney General, Chief of Staff to the President, Director of Central Intelligence, Assistant to the President for National Security Affairs, Chairman of the Joint Chiefs of Staff, "Humane Treatment of al Qaeda and Taliban Detainees" (Washington, DC, 7 February 2002). The memorandum states: "By its terms, Geneva applies to conflicts involving 'High Contracting Parties,' which can only be states. Moreover, it assumes the existence of 'regular' armed forces fighting on behalf of states. However, the war against terrorism ushers in a new paradigm, one in which groups with broad international reach commit horrific acts against innocent civilians, sometimes with the direct support of states. Our nation recognizes that this new paradigm-ushered in not by us, but by terrorists-requires new thinking in the law of war, but thinking that should be nevertheless consistent with the principles of Geneva."

2 John Reid, “Twenty-First Century Warfare - Twentieth Century Rules," RUSI Journal 151, no. 3 (2006): 14-17.
Dr. Sibylle Scheipers is a lecturer in international relations at the University of St. Andrews and a senior research associate at Oxford University's Changing Character of War program. 
The assumption on which this assessment is based is that the law of armed conflict was drafted with a view to symmetrical interstate wars, whereas wars in the twenty-first century will be asymmetric conflicts in which regular state forces are fighting against a variety of actors such as terrorists, rebels, insurgents, militias, mercenaries, pirates, and so on, who are usually lumped together under the notion of nonstate actors. Symmetry implies reciprocity, meaning all parties to a conflict will abide by the same rules. The concept of belligerent reprisals, which were a legitimate means of war until the drafting of the Geneva Conventions in 1949, reflects this assumption of reciprocity: if one party to a conflict systematically breaks the law of armed conflict, the opponent is entitled to retaliate in kind or in another punitive way to ensure the law is upheld.

In asymmetric conflicts - and it is important to note that the notion of asymmetric warfare predates the War on Terror and encompasses not only terrorism but also conflicts in the peripheries of the international system variously labeled new wars, low-intensity conflict, military operations other than war, or fourth generation warfare-reciprocity is by definition undermined. ${ }^{3}$ The concept of asymmetric warfare implies that a weaker opponent with fewer military capabilities and resources is pitted against a powerful state actor. Weak opponents will use almost any means at their disposal to achieve their aims in war; they will use terrorist tactics, attack civilians, plant roadside bombs, and kill prisoners if they happen to capture any. ${ }^{4}$ However, weak opponents, although not abiding by the law, will challenge any perceived transgression on the part of the state actor and exploit it in the court of international public opinion. They will even provoke such transgressions by using human shields around high-value targets. This vulnerability of the stronger side to allegations of violations of the law of armed conflict has been referred to as "lawfare." 5 Hence, in this perspective, championing the law means all sorts of pain, but no gain, for the stronger side in an asymmetric conflict.

The common conclusion to this type of analysis is that the law of armed conflict is outdated, that it needs to be either suspended or revised, and that we should not be surprised to see new moral and legal norms on the use of armed force arising and becoming institutionalized. The question rarely asked is whether the law was really drafted with a view to symmetrical interstate war-that regulative ideal that scholars, commentators and policymakers alike seem to grasp to understand the unruly and confusing battlefields of the twenty-first century.

\section{From Lieber to Additional Protocol I}

One of General Henry W. Halleck's first acts as General-in-Chief of all the Union armies was to commission a legal memorandum from

3 For a general overview on asymmetric warfare, see Rod Thornton, Asymmetric Warfare: Threat and Response in the Twenty-First Century (Cambridge: Polity, 2007). On the alleged global transformation of warfare more generally, Mary Kaldor, New and Old Wars: Organized Violence in a Global Era (Stanford, CA: Stanford University Press, 2007); Martin van Creveld, The Transformation of War (New York: Free Press, 1991). On fourth generation warfare, see T.X. Hammes, The Sling and the Stone: On War in the Twenty-First Century (St Paul, MN: Zenith Press, 2006).

4 Michael L. Gross, Moral Dilemmas of Modern War: Torture, Assassination and Blackmail in an Age of Asymmetric Conflict (Cambridge: Cambridge University Press, 2010). For a critique of this narrow reading of reciprocity, see Mark Osiel, The End of Reciprocity: Terror, Torture and the Law of War (Cambridge: Cambridge University Press, 2009).

5 See, for instance, Charles C. Dunlap, "Lawfare amid Warfare," The Washington Times, August 3, 2007. 
Francis Lieber on the problem of guerrilla warfare. Halleck, who had a background in law, was animated by the desire to prevail in the struggle with Confederate leadership over the legitimacy of the use of irregular fighters which had developed alongside the actual military confrontation on the battlefields of the American Civil War. On 28 April 1862, the Confederate Congress adopted the Partisan Ranger Act, which stipulated the president could authorize bands of partisan rangers to operate against Union forces behind enemy lines. Halleck was adamant this was a breach of the customs of war and hoped Lieber would back him up with an authoritative legal opinion. However, the resulting text entitled Guerrilla Parties Considered with Reference to the Laws and Usages of War (1862) must have been a disappointment for Halleck. Lieber produced a remarkably detailed and nuanced legal assessment of irregular fighters, distinguishing among six different categories: freebooters; brigands; partisans and free corps; spies, rebels, and conspirators; war rebels; and the spontaneous rising en masse. ${ }^{6}$ Of these six categories of irregulars, only the partisans and free corps and the rising en masse, even without uniforms, were lawful belligerents in Lieber's eyes. The guerrilla oscillated between the brigand, the partisan, and the rising en masse, which, according to Lieber, made it particularly difficult to determine his or her legal status.

This was clearly not what Halleck had expected. For Halleck, even partisans, meaning regular units that operated independently from their command and, hence, the most regular of all irregular fighters were to be considered unlawful belligerents and shot, not to mention risings en masse or guerrillas. Halleck's disappointment may have been the reason for his reluctance to support Lieber's more ambitious project, which would become known as the Lieber Code. ${ }^{8}$ Lieber's treatment of irregular fighters in the Code, written in 1863, is less nuanced. He retained the distinction between the lawful partisan and other unlawful types of irregular fighters, thus insisting on this difference of opinion with Halleck. However, he did not mention the rising en masse, nor did he discuss the problematic question of the legality of the guerrilla.

Given Halleck's opinion on the problem of irregular fighters, it is not surprising that much of Lieber's writing on the issue was lost on Union commanders and troops in the field. However, there was a section in the Lieber Code that was much more closely followed by Union officers, and that was the section on "Insurrection-Civil War-Rebellion." Lieber has often been credited with trying to codify protections for civilians in war. ${ }^{10}$ But that is only partly accurate. In fact, Lieber was rather ambivalent when it came to protecting civilians from the effects of war. He did not conceptualize the civilian as a protected group of persons as such; he used the term "unarmed citizens." More importantly, the

6 Richard Shelly Hartigan, Lieber's Code and the Law of War (Chicago: Precedent Publishing, 1983), 34-39.

7 Ibid., 40

8 When Lieber wrote to Halleck in November 1862, suggesting a more comprehensive set of rules for the conduct of the war, Halleck replied brusquely, "I have no time at present to consider the subject." It was only due to Lieber's perseverance the code was finally adopted; Mark Grimsley, The Hard Hand of War: Union Military Policy towards Southern Civilians, 1861-1865 (Cambridge: Cambridge University Press, 1995), 149.

9 Hartigan, Lieber's Code, 60.

10 See, for instance, Theodor Meron,"'Lieber's Code and the Principles of Humanity," Columbia Journal of Transnational Law 36, no. 22 (1997): 269-81. 
Lieber Code contained two contrasting approaches to the treatment of what we would call "civilians" today. On one hand, Lieber stated the "unarmed citizen is to be spared in person, property, and honor as much as the exigencies of war will admit." 11 On the other, in the section on "Insurrection-Civil War-Rebellion," Lieber wrote:

\begin{abstract}
The military commander of the legitimate government, in a war of rebellion, distinguishes between the loyal citizen in the revolted portion of the country and the disloyal citizen. The disloyal citizen may further be classified into those citizens known to sympathize with the rebellion without positively aiding it, and those who, without taking up arms, give positive aid and comfort to the rebellious enemy without being bodily forced thereto. . . . The commander will throw the burden of war, as much as lies within his power, on the disloyal citizens, of the revolted portion or province, subjecting them to a stricter police than the non-combatant enemies have to suffer in regular war . . he may expel, transfer, imprison, or fine the revolted citizens who refuse to pledge themselves anew as citizens obedient to the law and loyal to the government. ${ }^{12}$
\end{abstract}

Lieber's legal approach to a war of rebellion made protections for civilians dependent on their behavior and even their political Weltanschauung. It effectively put all civilians in enemy territory under general suspicion. Hence, the Lieber Code "erected very few strong barriers against severe treatment" of civilians. ${ }^{13}$ This approach was closely followed because Lieber had, in fact, taken his inspiration for this section from the prevailing practice in the field. The three-tier approach distinguishing between loyal, passively disloyal, and actively disloyal citizens had been developed in 1862 by local Union commanders in Missouri and had later been approved by Halleck himself. ${ }^{14}$ Lieber only mirrored what was already common practice in the field.

Soon after the end of the American Civil War, the question of how to deal with irregular fighters became pressing once again, though this time on the European side of the Atlantic. In 1870, the Prussian army had defeated the French forces and all but captured Paris when the French government, now under the leadership of the republican Leon Gambetta, made a last ditch attempt to stave off defeat. In October 1870, Gambetta called his fellow citizens to resist the German occupation forces as francs-tireurs (literally "free shooters") and to attack their lines of communication. The Prussian leadership was enraged. Despite the French government's insistence that francs-tireurs were lawful belligerents, the Prussian headquarters issued an order according to which francs-tireurs were not to be treated as prisoners of war, but to be executed on capture. This order was later amended and the new decree stipulated ten years of forced labor rather than immediate executions. However, German forces treated most francs-tireurs as prisoners of war when captured. Yet, civilians had to endure harsh treatment by the German forces, in particular in those areas where francs-tireurs were active. Just as the Union forces in the American Civil War, the Germans chose a punitive approach based on the assumption that it was ultimately the local population that was responsible for the francs-tireurs problem.

11 Ibid., 49

12 Ibid., 71, emphasis added.

13 Grimsley, Hard Hand, 150.

14 For a more detailed account, see Sibylle Scheipers, Unlawful Combatants: A Genealogy of the Irregular Fighter (Oxford: Oxford University Press, forthcoming 2014), chapter 2. 
The defining feature of both the American Civil War and the Franco-Prussian War was that the opponents had divergent ideas of who was a lawful belligerent. It was no wonder, then, that contemporaries felt the need to clarify the laws of war and, in particular, the definition of irregular fighters. On the American side, the Lieber Code served that purpose, although Union commanders honored its provisions on irregular fighters more in the breach than in the observance. In Europe, the Franco-Prussian War sparked efforts to negotiate and codify the laws of war. Without doubt, it was the experience of the francs-tireurs problem that provided primary impetus. Negotiations in Europe were heavily influenced by the Lieber Code, which formed the basis of several draft proposals debated at the Brussels conference in 1874.

The conference failed to produce anything acceptable to all parties involved; hence, no law was adopted. The question of the lawfulness of irregular fighters had become so entangled with issues of military and political power as well as with ideological differences that no agreement was possible among the major European powers. However, the attempts at legal codification opened the definitional battlefield and clarified different positions within it. Political cleavage lines soon became clear: Germany and Russia, both of which possessed large regular armies, intended to keep the definition of lawful belligerency highly restrictive, hence not allowing for a defensive levée en masse or even militia forces. In contrast, smaller states that relied on militias for their national defense were opposed to this restrictive proposal. They were supported by Britain and France. The Brussels conference broke up after one month of negotiations, and no legal text was adopted. Only a declaration was issued. However, international lawyers were apparently not discouraged by this outcome. In 1880, the Oxford Institute of International Law published its own manual entitled The Laws of War on Land.

The Brussels declaration and the Oxford Manual were similar with respect to structure and content. Both texts were more inclusive than the Lieber Code regarding the question of the lawfulness of irregulars. Articles 9 and 10 of the Brussels declaration stipulated that regular armies, militia forces, volunteer corps, and a spontaneous rising en masse against invasion were lawful forms of national defense. ${ }^{15}$

The fact that neither the Brussels declaration nor the Oxford Manual garnered widespread acceptance demonstrated that the question of the definition and treatment of irregular fighters was still undecided. Consensus on the definition of lawful belligerency was only reached in the 1907 Hague Convention on the Rules and Customs of War on Land. The Hague Convention retained the provisions on the lawfulness of the defensive rising en masse in nonoccupied territory, although it did not mention other military organizations included in the Oxford Manual, such as national guards, landsturm, and free corps. ${ }^{16}$

In sum, the history of the law of armed conflict from Lieber to the Hague Convention shows, first, that codification efforts were triggered by the experience of irregular fighting in the American Civil War and the

15 “The Laws of War on Land," Institute of International Law at Oxford, 9 September 1880, http:// www1.umn.edu/humanrts/instree/1880a.htm

16 Annex to the Convention "Regulations Respecting the Laws and Customs of War on Land," Section I, Chapter I, Art 1-2, in Documents on the Laws of War, ed. Adam Roberts and Richard Guelff (Oxford: Oxford University Press, 2000), 73. 
Franco-Prussian War. Second, it demonstrates that the remits of lawful belligerency were contested between major political actors. Finally, it shows that, due to this contestation, the legal definition of the irregular was achieved ex negativo, and there were no provisions on the treatment of this category of persons. While Lieber had initially started with a detailed list of defined categories of irregular fighters, the Hague Convention defines only lawful belligerency. Hence, according to the Hague law, irregular fighters are all combatants who do not qualify as lawful belligerents and who do not enjoy legal protections such as prisoner of war status.

While much nuance and detail was thus lost from Lieber's initial texts on the issue of defining irregular fighters, the tendency to blame civilians for the activity of irregulars and to make them liable to punitive measures was carried forward to the early European texts. Both the Brussels declaration and the Oxford Manual stipulate that occupying powers can levy fines on the population. ${ }^{17}$ The Oxford Manual is more explicit when it comes to the protection of civilians - although it must be kept in mind that the legal texts at the time still neither used nor defined this category — and states, "It is forbidden to maltreat inoffensive populations." 18 At the same time, it makes clear that "The inhabitants of an occupied territory who do not submit to the orders of the occupant may be compelled to do so." ${ }^{19}$ Hence, the upshot of the early attempts at codifying the laws of war is that the civilian population only warrants protection if it fully subjects itself to the occupying forces. This approach to the laws of war was as much about humanizing war and protecting local populations against wanton cruelty as it was about disciplining civilians. Its outlook on civilians was always potentially punitive, and the reason for this harsh posture was the civilians' potential links with irregular fighters: they could aid them or take up arms themselves. So if the line between the regular and the irregular was unclear at the end of the nineteenth century, the boundaries between the irregular and the civilian were even more questionable. This tendency was carried forth in the Hague laws. ${ }^{20}$ The atrocities German forces, imbued with a fear of francs-tireurs that amounted to paranoia, committed in Belgium and northern France during the first months of World War I, were proof that the punitive approach had become even more significant in military operations on the ground. ${ }^{21}$

Changes in the law would only come with the 1949 Geneva Conventions, which provided more thorough protections for civilians in occupied territory. This was once again precipitated by a transformation in the perception of the irregular fighter. The Second World War is mostly remembered as a classical example of symmetric interstate war, but it had

17 "Project of an International Declaration Concerning the Laws and Customs of War," Art 36-48, Brussels, 27 August 1874, http://www.icrc.org/ihl/INTRO/135; "The Laws of War," Art $43-60$.

18 "The Laws of War," Art 7.

19 Ibid., Art 48.

20 Karma Nabulsi, "Evolving Conceptions of Civilians and Belligerents: One Hundred Years after the Hague Peace Conferences," Civilians in War, ed. Simon Chesterman (Boulder, CO: Lynne Rienner, 2001), 9-24.

21 John Horne and Alan Kramer, German Atrocities, 1914: A History of Denial (New Haven, CT: Yale University Press, 2002). 
large irregular aspects. ${ }^{22}$ While resistance groups fighting against Nazi occupation in Europe and Japanese occupation in Asia may not have had a decisive strategic impact, the experience of irregular resistance and appalling Axis countermeasures left an important legacy for the development of the law of armed conflict after the war. It was difficult to uphold the image of the irregular fighter as the unlawful rebel given that the war had vindicated the moral cause of the resistance movements.

The uncomfortable truth was that the potentially punitive approach towards civilians in occupied territory embodied in the Hague law had done little to reign in the genocidal excesses of the German occupation forces on the eastern front and, to a lesser extent, in occupied western Europe. Of course, the Hague law had neither envisaged nor condoned the killing of millions of eastern European Jews, but the punitive perspective towards irregular fighters and their alleged civilian supporters had probably played a certain part in making the actions of the German occupation forces justifiable in the minds of some German officers and troops. ${ }^{23}$ Hence, it was logical to tackle the question of protections for civilians in occupied territory as one of the most pressing issues in the 1949 Geneva Conventions. The Fourth Geneva Convention, the Civilians Convention, accordingly represents the most important legal innovation achieved in Geneva. It demarcates the civilian as a separate category of persons entitled to specific protections in war and breaks with the potentially punitive approach to civilians by prohibiting civilian reprisals, fines, and the taking of hostages. ${ }^{24}$ It also symbolically separates the civilian from his or her alleged links with irregular fighters.

At the same time, the Geneva Conventions made little progress with respect to the definition of and the provisions for irregular fighters. The articles on lawful belligerency are essentially taken from the Hague rules. Again, this decision boiled down to political considerations. The French delegation to the Geneva Conference, which included many former members of the resistance, had lobbied for the inclusion of provisions on conditions for lawful acts of resistance against occupying forces, but the United States and the United Kingdom delegations had no interest. In the end, France had to realize that it had switched sides: it was no longer occupied, but part of the Allied occupation forces in Germany. ${ }^{25}$

However, in one important respect, the Geneva Conventions did introduce new provisions for irregular fighters: Common Article 3 spells out minimum protections to apply in armed conflicts "not of an international character." These include the prohibition of torture and degrading treatment and the prohibition of executions "without previous judgment

22 Jonathan E. Gumz even makes the case for reconceptualizing the Second World War "as a series of unbounded insurgencies in that they were not solely confined to professional militaries alone, but rather involved various ideological and nationalized groups"; "Reframing the Historical Problematic of Insurgency: How the Professional Military Literature Created a New History and Missed the Past," Journal of Strategic Studies 32, no. 4 (2009): 553-88.

23 However flimsy their statements in defense of their actions might have been, some officers at the SS-Einsatzgruppen trial in Nuremberg argued that the executions they carried out had been lawful, as “those who were killed had been found guilty of partisan warfare and robbery." Hilary Earl, The Nuremberg SS-Einsatzgruppen Trial, 1945-1958: Atrocity, Law and History (Cambridge: Cambridge University Press, 2009), 144.

24 Geneva Convention Relative to the Protection of Civilian Persons in Time of War of August12, 1949, Part I, Art 4, 13, 33 and 43, in Documents, ed. Roberts and Guelff, 302, 306, 312.

25 Karma Nabulsi, Traditions of War: Occupation, Resistance, and the Law (Oxford: Oxford University Press, 1999), 14; Geoffrey Best, War and Law since 1945 (Oxford: Clarendon Press, 1994), 118. 
pronounced by a regularly constituted court." ${ }^{26}$ Not surprisingly, colonial powers, foremost the United Kingdom, were alarmed by the broad remit of the article. At the time of the Geneva Conference, British forces were fighting a communist insurgency in Malaya and feared that Common Article 3 was "possibly restrictive to the operations." 27 Both Britain and France attempted to tackle the problem of possible restrictions on military operations in the colonies that Common Article 3 entailed by insisting the wars in Kenya and in Algeria, for instance, were domestic emergencies that did not amount to armed conflicts of a noninternational character.

Given these strong political interests, it is not surprising legal innovations regarding irregular fighters were developed only after the major European powers lost their colonies. The rationale for the Additional Protocols (AP I and II) of 1977 once again arose from historical hindsight: the wars of decolonization had shown that irregular fighters sometimes do fight morally defensible wars, albeit with methods that are difficult to square with the requirements of lawful belligerency as spelled out in the Hague and Geneva laws. Yet their shortcomings may be excusable in the light of their situation: due to colonial oppression, many of them were unable to conform to the requirements for lawful belligerency, and punishing them would have perpetuated the oppressive regime they were fighting. The solution was to narrow the conditions for lawful belligerency by stipulating that lawful combatants are members of any armed forces, units, or groups commanded by a person responsible to a party to the armed conflict in question, "even if that Party is represented by a government or authority not recognized by an adverse Party." ${ }^{28}$ As a procedural requirement, AP I stipulates that combatants have to carry their arms openly while engaged in an attack or in a military operation preparatory to an attack. ${ }^{29}$

In spite of this innovation, the law of armed conflict retained its negative approach to the problem of irregular fighters. AP I does lower the requirements for combatant privilege, and hence increases the variety of persons who qualify for prisoner of war status. At the same time, it fails to address the question of how to categorize persons who fail the privileged combatancy test, either because they violate the organizational or procedural requirements set out in Articles 43 and 44, or because they are civilians who take up arms against occupying forces. Various legal memos issued by subsequent US administrations, as well as academic discourse, have used the term "unlawful combatants" as a label for individuals who are neither privileged combatants nor "peaceful" civilians. ${ }^{30}$ Others have vehemently argued that the term unlawful combatants is not a category of the law of armed conflict. ${ }^{31}$ Even if we

26 Common Article 3 to the Geneva Conventions, Documents, ed. Roberts and Guelff, 198.

27 Army Council Secretariat brief for Secretary of State for War, 1 December 1949, quoted in Hugh Bennett, Fighting the Mau Mau: The British Army and Counter-Insurgency in the Kenya Emergency (Cambridge: Cambridge University Press, 2013), 68.

28 Protocol Additional to the Geneva Conventions of 12 August 1949, and Relating to the Protection of Victims of International Armed Conflicts (Protocol I), Section II, Art 43 (1), in Documents, ed. Roberts and Guelff, 444.

29 Ibid., Section II, Art 44 (3), in Documents, Roberts and Guelff, 444.

30 Yoram Dinstein, The Conduct of Hostilities under the Law of International Armed Conflict (Cambridge: Cambridge University Press, 2004), 30ff.

31 International Committee of the Red Cross, "Report on the Second Expert Meeting on the Notion of Direct Participation in Hostilities," The Hague, 25-26 October 2004, 17. 
leave aside the question of labels, the problem remains that there are very few legal provisions on the treatment of such persons. ${ }^{32}$ Moreover, major international actors such as the US and Israel have not ratified Additional Protocol I, and are hence only bound by those provisions on irregular fighters that have become customary international law (Articles 43 and 75 in particular).

\section{Twenty-First Century Conflicts}

The history of the codification of the law of armed conflict shows that it was not exclusively drafted with a view to symmetrical interstate war. On the contrary, it was the experience of problems posed by irregular fighters which propelled the law step by step from its early stages to the Additional Protocols of 1977. One important flaw of the law of armed conflict was corrected along the way: the idea that civilians were liable for punishment if irregular fighters had operated in their territory. Another major shortcoming is its negative approach to the definition of irregular fighters and its lack of provisions for this status, which continued through the different codification stages.

So those scholars and legal practitioners who argue the United States (and other nations) did not have much to go on in terms of the law regarding the question of how they should treat al Qaeda suspects and other irregular fighters in recent operations were not entirely wrong, though the reason for this was not that the law is outdated. ${ }^{33}$ Rather, it is related to the fact that major international actors in successive rounds of the law's codification had no interest in spelling out a detailed definition of unlawful belligerency and in stipulating provisions for the treatment of persons who would fall into this category. The law's exclusionary approach towards irregular fighters made it all too easy to marginalize them simply because they were perceived as an anomaly for which the law did not provide.

This perspective has given the debate on irregular fighters an unfortunate twist in that it has prevented the most relevant question from being asked: how should the West treat irregular fighters to further its strategic aims in military operations? Instead, it has led to legal(istic) extremes. Two extreme positions on a spectrum of different opinions on the legal treatment of irregular fighters emerged. Both share the view that the law is outdated, but come to opposite conclusions on the way forward. At one end of the spectrum are those who aim to create more explicit rules and add new restrictions; on the other end are those who argue the law of armed conflict does not apply to irregular fighters and they are, hence, without any legal rights or protections. Both positions are fraught with difficulties.

Regarding the first position, it is an oft-repeated observation among critical international lawyers, commentators, and activists that the

32 Article 45 of the Additional Protocol stipulates that those who are denied prisoner of war status for failing to meet the requirements of lawful belligerency are entitled to a review of their status "before a judicial tribunal." Even if they are not granted prisoner of war status, they must be treated in accordance with Common Article 3 and Article 75 AP I, which is regarded as customary international law; all printed in Documents, Roberts and Guelff,446, 198, 463.

33 See, for instance, Benjamin Wittes, Law and the Long War: The Future of Justice in the Age of Terror (New York: Penguin, 2008); John B. Bellinger III, "Legal Issues Related to Armed Conflict with Non-state Groups," in Prisoners in War, ed. Sibylle Scheipers (Oxford: Oxford University Press, 2010), 251-62. 
West's approach to irregular fighters in the War on Terror, and in particular to their detention and interrogation, has been characterized by the creation of legal "black holes, vacuums" and the exploitation of legal "loopholes." 34 The call for more law seemed to be a logical conclusion. However, it is not entirely correct that the most disastrous aspects of the treatment of irregular fighters in recent conflicts stemmed from the absence of law or legal reasoning. On the contrary, the numerous legal memos on irregular fighters issued since 2001 were written by lawyers and used legal arguments and concepts. ${ }^{35}$ Against this background, it is hard to see how the default option of more law should have provided viable safeguards and solutions. Moreover, the fact that there is a range of concepts and ideas on how the law of armed conflict should be updated to regulate the treatment of irregular fighters suggests that arriving at a new internationally binding consensus would be difficult and time-consuming. Limited attempts at formulating preliminary rules such as the Copenhagen Process on the Handling of Detainees, in which the North Atlantic Treaty Organization (NATO) and its member states, the United Nations, and the International Committee of the Red Cross (ICRC) are involved, are under way. ${ }^{36}$ While these preliminary debates are laudable and useful, even such limited attempts will take time to produce results that could be taken as firm guidance in operations on the ground.

On the other end of the spectrum are those who assume that the law of armed conflict does not apply. However, as discussed above, Common Article 3 to the Geneva Conventions and Article 75 AP I, offer minimum protections for all categories of persons in armed conflict, hence also for irregular fighters. These sources comprise prohibitions against murder, torture, and inhumane and degrading treatment; of enforced prostitution; of the taking of hostages; of collective punishments; and of threats of any of those acts. Furthermore, they spell out some basic procedural rules for prosecuting individuals for penal offences. ${ }^{37}$ They do allow for the detention or internment of individuals who may pose a threat to the security of states involved in an armed conflict. What they do not clarify is first, what kind of evidence such detention has to be based and, second, what the criteria and procedures for continued detention or, alternatively, release are. ${ }^{38}$

34 To a certain extent, this charge is also leveled against the practice of targeted killing. Although the legal discourse on targeted killing is related to the issues discussed here, I cannot cover it in this context for reasons of space limitations. For a useful legal starting point, see Nils Melzer, Targeted Killing in International Law (Oxford: Oxford University Press, 2008).

35 Most of the memos issued by the Bush administration in the years 2002-04 were collected and published in Karen J. Greenberg, Joshua L. Dratel, and Anthony Lewis, eds., The Torture Papers: The Road to Abu Ghraib (Cambridge: Cambridge University Press, 2005). Later memos by US administrations as well as legal memos by other NATO states that are relevant for the treatment of irregular fighters remain classified.

36 "Copenhagen Process on the Handling of Detainees in International Military Operations," Udenrigsministeriet Ministry of Foreign Affairs of Denmark, http://um.dk/en/politics-and-diplomacy/ copenhagen-process-on-the-handling-of-detainees-in-international-military-operations/; on the debate on new legal rules on detention, see also Adam Roberts, "Detainees: Misfits in Peace and War," in Prisoners in War, ed. Sibylle Scheipers (Oxford: Oxford University Press, 2010), $276 \mathrm{f}$.

37 In addition, some parts of international human rights law may apply as well in specific situations. However, human rights protections would probably not go substantially beyond the principles spelled out in article $75 \mathrm{AP}$ I, although specific principles such as the non-refoulement rule (covering the prohibition of transferring detainees to a state that may torture them) would have an effect on operations.

38 Roberts, "Detainees," 270. 
In the absence of new legal rules, political and strategic solutions to theseissues need to be found. The basic challengeis to gear the treatment of irregular fighters in theaters comparable to Afghanistan and Iraq towards the aim of political stabilization and societal reconciliation. Asymmetric conflicts and the dilemmas related to the treatment of irregular fighters are not new. What is new, however, is the emphasis on sustainable pacification-stabilization is the current buzzword-as the ultimate goal in these wars. Against this background, it is questionable whether a purely exclusionary approach is the way forward. Political stabilization requires societal reconciliation and the reintegration of irregular fighters into the social and political system of the target state in question. The negotiations with Taliban leaders, which started in June 2013 in Qatar, bear witness to the West's (belated) acknowledgment of reconciliation and reintegration as a vital component of long-term stabilization.

This perspective applies in particular to those individuals whose allegiance is first to the local insurgency, that is, fighters who are not involved in global terrorist operations. The question of their treatment is most usefully discussed from the perspective of war's end: how ought fighters be treated to enable their successful reintegration into society at the end of the war? How will their treatment during the conflict impact on the chances of post-conflict reconciliation and hence the achievement of a lasting peace? ${ }^{39}$ Supposedly more enlightened commentators, in particular on the European side of the Atlantic, often suggest that treating them as criminals rather than gratifying them with combatant status is the way forward when it comes to treatment of irregular fighters. However, there are indications from historical cases, in particular the United Kingdom's experience with the Irish Republican Army in the 1970s and 1980s, that acknowledging some kind of combatant status of detained irregular fighters and local terrorists can open the road to long-term political solutions. ${ }^{40}$ On the other hand, criminal prosecutions would be the preferable solution for those who have been suspected of involvement in the planning or implementation of terrorist attacks of a global nature. The fact these prosecutions have failed seems to have little to do with principle obstacles. Rather, the two greatest inhibiting factors were, first, that the military commissions initially charged with putting this group of individuals on trial were based on rules and procedures that were so flawed they proved almost impossible to correct. Secondly, parts of the evidence to be used against these suspects was based on torture and hence inadmissible in any lawful trial. ${ }^{41}$ These complications could have been avoided had the minimum protections stipulated in Article 75 AP I been implemented.

39 For a more detailed discussion of this issue, see Sibylle Scheipers, "Conclusion: Prisoners and Detainees in Current and Future Military Operations," in Prisoners in War, 313-20.

40 While the Thatcher government never officially accepted the IRA's claim that imprisoned IRA fighters were POWs, it did tacitly concede to most of the IRA hunger strikers' demands, which principally aimed at removing the stigma of criminalization from IRA prisoners. These concessions occurred at a time when the IRA's engagement with the political system increased. The treatment of IRA prisoners had at the very least a stabilizing effect on the IRA's nonviolent political engagement. See also Richard English, Armed Struggle: The History of the IRA (London: Macmillan, 2003), chapters 5 and 6.

41 Roberts, "Detainees," 272. 


\section{Conclusion}

The law of armed conflict is a peculiar field of law as it refuses to regulate a phenomenon that repeatedly provided the main impetus for its progressive codification: irregular fighters. Rather than providing definitions and rules on the treatment of irregular fighters, successive generations of lawmakers chose a negative approach to the phenomenon: the irregular is he (or she) who does not qualify for privileged combatancy and the attendant privileges and protections. This peculiarity of the law gave rise to claims that the established legal rules as laid down in the Hague and the Geneva conventions are outdated and inapplicable to wars in twenty-first century.

However, what these claims overlook is that the law was influenced by considerations of political power and military expediency at all stages of its codification. Halleck rejected Lieber's ideas on the treatment of irregular fighters, as he found them too lenient and feared their implementation might endanger Union victory in the American Civil War. Neither Germany nor Russia had an interest in considering small state militias as lawful belligerents. And while the Allies after World War II perceived it as both ethical and useful to enhance protections for civilians in war, France and Britain, in particular, were wary of codifying the law in such a way that it might endanger their colonial authority. In all these instances, powerful states had a strong interest in excluding irregular fighters from the remits of the law of armed conflict.

International law, including the law of armed conflict, is mainly made by states, and it is neither surprising nor entirely reprehensible that it bears the mark of state interest. What is important, however, is to be aware of the fact that at the beginning of the twenty-first century, the outright exclusion of irregular fighters may not be in the West's strategic interest. As we have seen, asymmetric conflicts are not new. Irregular fighters have existed at all times in the history of war. What is new, however, are the West's strategic and political aims of stabilization in conflicts against irregular fighters. In the twenty-first century, western states are facing the challenge of bringing the law of armed conflict in line with the strategic aim of stabilization or, rather, to apply it in a way that does not undermine this aim. 


\section{Defeating Violent Nonstate Actors}

\author{
Robert J. Bunker
}

\begin{abstract}
The role of landpower "at war" is as integral to US defense needs as landpower "short of war." But what about the role of landpower between these two in environments in which violent nonstate actors dominate? In such cases, it is best to devolve opposing violent nonstate actors as quickly as possible so policing forces can implement follow-on strategies. Landpower can help provide security conditions under which these strategies can be facilitated.
\end{abstract}

And just like their allies in Al Qaeda, this new Taliban is more network than army, more of a community of interest than a corporate structure.

GEN Stanley A. McChrystal ${ }^{1}$

andpower represents the application of force generated by conventional militaries - be they classical Roman legionnaires, medieval European knights, or modern US soldiers. Such power is generated by land forces, essentially the "[p]ersonnel, weapon systems, vehicles, and support elements operating on land to accomplish assigned missions and tasks." "2 Boots-on-the-ground integrated into Brigade Combat Teams (BCTs) represents our state-of-the art operational approach to ground combat operations. In turn, official publications define landpower and what it influences:

[L]and power. ... The ability—by threat, force, or occupation-to gain, sustain, and exploit control over land, resources, and people. [It is] the primary means to impose the Nation's will on an enemy, by force when necessary; establish and maintain a stable environment that sets the conditions for political and economic development; .....3

The integral nature of landpower "at war" to US defense needsessentially in interstate war-is well recognized, as is the role of the United Sates Army as the nation's principal land force. ${ }^{4}$ The contribution of landpower "short of war" - for influence, deterrence, and humanitarian purposes - is also well accepted. More problematic is the relationship of landpower to environments in which violent nonstate actors dominate. Far less obvious is the role of landpower in irregular warfare, intrastate war waged by belligerents who are not states - along with its attendant organized criminal, illicit economic, and governmental corruption components. ${ }^{5}$ The lessons of Iraq and Afghanistan suggest

1 Stanley A. McChrystal, "It Takes a Network: The New Front Line of Modern Warfare," Foreign Policy (March-April 2011), http://www.foreignpolicy.com/articles/2011/02/22/ it_takes_a_network.

2 Via JP 3-31. See Joint Chiefs of Staff, Department of Defense Dictionary of Military and Associated Terms, Joint Publication 1-02. November 8, 2010 (As Amended Through 16 July 2013): 163, http:// www.dtic.mil/doctrine/new_pubs/jp1_02.pdf.

3 U.S. Department of the Army, The U.S. Army Capstone Concept, TRADOC Pamphlet 525-3-0, (Washington, DC: U.S. Joint Chiefs of Staff, December 19, 2012), 38, 39.

4 Ibid.

5 Odierno, Amos, and McRaven, Strategic Landpower, 3.
Dr. Robert J. Bunker is a Distinguished Visiting Professor and Minerva Chair at the Strategic Studies Institute, US Army War College. He is also Adjunct Faculty, Department of Politics and Economics, Claremont Graduate Univ. He has published, coauthored, and edited publications in numerous venues. He is currently focused on dark globalization and new forms of insurgency. 
that, while operational successes in such campaigns may be won at a high cost in US treasure, they are not economically sustainable. Further, the strategic goals of those campaigns - the desired results which would fulfill the multinational security objectives — could only be partially met. While the Ba'athist and Taliban governments have been removed from power-and more importantly al Qaeda forces decimated - both states are fragile, suffer from tribal and sectarian violence, and are beset with dysfunctional governments. At best, the campaigns waged in Iraq and Afghanistan can be considered only partial victories, at worst, partial failures. $^{6}$

With these perceptions in mind, this article will look at the relationship of landpower to violent nonstate actors. In order to do this, these actors first will be characterized along with their landpower-like attributes. Second, an overview of state policing and military forces will be provided. Third, landpower-related application strategies will be discussed. This article will end with some lessons concerning the need for networks when confronting violent nonstate actors and will provide a few cautionary remarks about "democratic capacity building" in the age of austerity now upon us.

\section{Violent Nonstate Actors}

The threats represented by violent nonstate actors are as old as the earliest states. Bandits, raiders, and pirates have plagued civilized peoples around the globe for millennia. A contemporary view of these actors is that they exist along a threat continuum from that of common criminals to criminal-soldiers (see Figure 1).

\section{Criminals}

Limited Violence Capability

Limited Corruption Capability

Parasitic with the State

\section{Criminal-Soldiers}

High Violence Capability

High Corruption Capability

Successor to the State

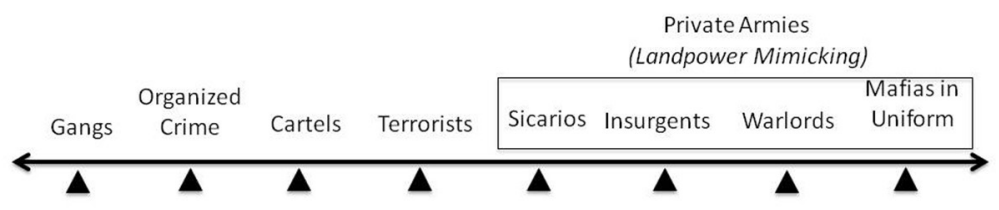

Figure 1. Violent Nonstate Actor Continuum

Criminals are at the left side of the continuum and are characterized as having limited violence and corruption capabilities. Gangs, organized crime, and less sophisticated cartels are representative of these more benign and somewhat less violent actors, as are robbers, brigands, and pirates. Criminals do not openly challenge police forces and have a parasitic relationship with a state; they seek to be left alone to engage in various nefarious activities and profit from the illicit economy.

Criminal-soldiers, nonstate soldiers, or illegal combatants, are at the right side of the continuum and are characterized as having high violence

6 For the debate on war ending models vis-à-vis al Qaeda, Afghanistan, and Iraq, see James M. Dubik, "Ringing True or Ringing Hollow?" Army, August 2013, 18-20. 
and corruption capability. Organized into private armies-as opposed to the public armies fielded by states-the more evolved actors are increasingly landpower-like in their attributes. Sicarios (cartel assassins and enforcers), insurgents, warlords, and mafias in uniform all represent landpower forces to varying degrees. As an example, a Los Zetas commando unit operating in the Mexican state of Tamaulipas, composed of a couple dozen armored sports-utility vehicles with mounted infantry in body armor and carrying small arms, definitely meets the Department of Defense definition of a land force.

The major threat criminal-soldiers present is that their relationship to the state is not a parasitic one like that of common criminals. Rather, they can be viewed as challengers and successors to the state. Via one process, the synergistic employment of violence and corruption, plato o plomo (silver or lead in Spanish), results in areas of impunity. These, in turn, lead to de facto shifts in governance by criminal organizations. Via another better known process, insurgents actively create a parallel shadow government to challenge and ultimately replace state institutions while carrying out targeted violence and assassination campaigns. Ultimately, if a violent nonstate actor has the financial resources to field a private army, it has "warmaking capability" which, in turn, means it has state capturing or making potentials."

It should be noted that terrorists represent a blended case along the continuum as some of them exhibit high violence potential—as in the case of the early al Qaeda spectaculars-but possess low corruptive capability. Further, most such groups are considered no better than criminals. Still, the blurred nature of transnational organizations such as al Qaeda brings us to three other facts about these increasingly significant and deadly actors. First, violent nonstate actors have been merging and blending for quite some time. Components of the al Qaeda network, and even those belonging to some of the more dominant Mexican cartels, exhibit gang, terrorist, insurgent, and organized criminal behaviors and patterns simultaneously. ${ }^{9}$ Second, violent nonstate actors are evolving towards more networked organizational forms but can manifest hierarchical, blended, and networked features. When under pressure from competing actors and states, they tend to devolve into networks as a defensive response-when dominant in a host environment more centralization becomes evident. Third, their numbers appear to be increasing as an outcome of external stressors placed on states due to the unexpected components of globalization, rapidly evolving technologies, and biosphere degradation (e.g., climatic changes). ${ }^{10}$

7 See JP 1-02 (footnote 2).

8 Charles Tilly, "War Making and State Making as Organized Crime," in Bringing the State Back In, ed. Peter Evans, Dietrich Rueschmeyer, and Theda Skocpol (Cambridge: Cambridge University Press, 1985), 169-191.

9 Michael Miklaucic and Jacqueline Brewer, eds., Convergence: Illicit Networks and National Security in the Age of Globalization (Washington, DC: National Defense University, 2013); Jennifer L. Hesterman, The Terrorist-Criminal Nexus: An Alliance of International Drug Cartels, Organized Crime, and Terror Groups (Boca Raton, FL: CRC Press, 2013).

10 The tipping point may have been reached now that at least one security scholar is suggesting an alternative to the state-centric paradigm-one in which some armed nonstate groups are now viewed as a positive force for global stability. See Robert Mandel, Global Security Upheaval: Armed Nonstate Groups Usurping State Stability Functions (Stanford, CA: Stanford University Press, 2013). 


\section{State Policing and Military Forces}

Police and military forces represent the coercive public agencies fielded by a state. Each force is meant to have a clear-cut institutional role with police utilized for intrastate crime prevention and the military utilized for interstate warfare to protect the state from opposing state militaries. A contemporary perspective on these forces can be seen in Figure 2, State Forces Continuum.

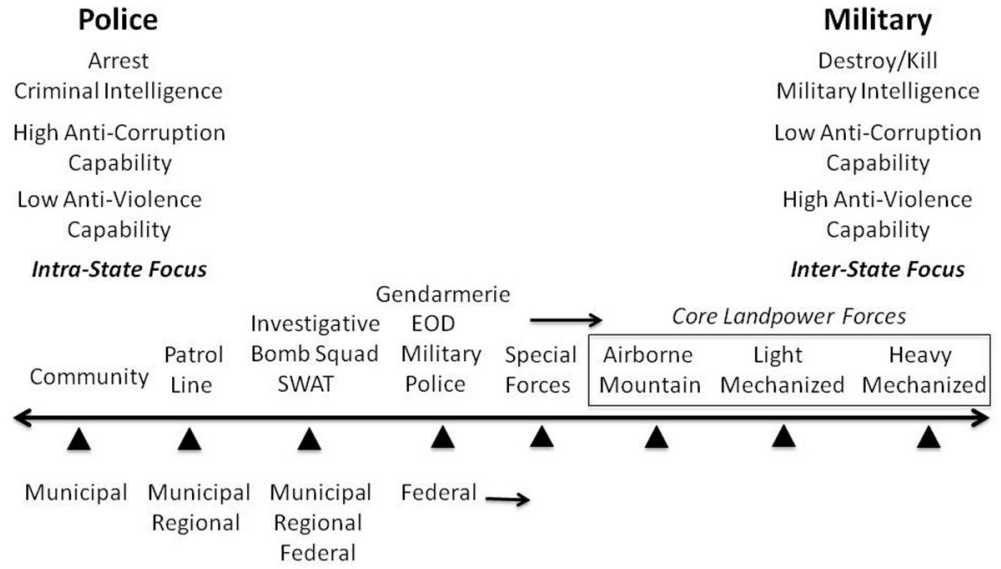

Figure 2. State Forces Continuum.

Police forces exist on the left side of this continuum and focus on crime prevention and the arrest of lawbreakers. Police utilize criminal intelligence procedures and typically work singularly or in pairs to complete their functions. While these forces are tactically adept, they have never developed or needed operational level capabilities. Community, patrol, line policing, and detective and investigative police units operate at the municipal, regional, and federal levels and are representative of these anticrime-focused activities. While police possess a low antiviolence capability - they are not meant or configured to confront armed and organized opposition forces-due to their investigative expertise, they possess a high anticorruption capability, especially within federal policing agencies. ${ }^{11}$

Military forces operate on the right side of the State Forces Continuum and are tasked with the mission of defeating opposing state-based military forces. The focus of these forces is that of organized destruction and killing under the condition of war between states. Since military forces oppose sentient opponents, they rely on military intelligence to understand enemy intent, capabilities, and futures. Core Army landpower forces are composed of airborne, mountain, and light and heavy mechanized units at the brigade level. While the military possesses a low anticorruption capability - it is not meant or configured to engage in investigative policing-it possesses a high antiviolence

11 Of course, when the policing agencies of a violent nonstate actor host country are corrupted, serious conditions result. While in some countries the military is less corrupt than the police, the military does not have the ability to root out corruption so impunity still results. 
capability far greater than the landpower-like capabilities of the more threatening violent nonstate actors.

The middle region of the continuum (Figure 2) represents the blurred zone of high intensity crime, low intensity conflict, and other crime-war descriptive constructs - it requires the fielding of both blended and specialized police and military forces. Domestic law enforcement has fielded Special Weapons and Tactics (SWAT) teams and bomb squads to contend with heavily armed criminals who use barricade techniques, are willing to confront law enforcement in limited firefights, and employ improvised explosive devices (IEDs). ${ }^{12}$ Internationally, formed police units are employed. On the armed forces side, military police and explosive ordnance disposal units engage in law enforcement and antiterrorist (and anti-insurgent) activities. Further, infantry units armed with less lethal weapons have been utilized for crowd control and antiriot missions. In turn, Special Forces - representing an unconventional landpower force-have been heavily tasked since $9 / 11$ to directly engage specific violent nonstate actors around the globe. One of the ongoing problems for state forces tasked to contend with these actors is that stovepipes exist concerning our response-such as countergang groups work separately from counternarcotics groups who, in turn, work separately from counterterrorism groups. ${ }^{13}$ This issue can become even more pronounced at the interstate level between cooperating state forces, especially between the American military and foreign police agencies.

In addition to the rise of state-based forces found in the middle of the state forces continuum, we are seeing the proliferation of private security and private military corporations contracting with states much like Swiss mercenaries and Italian condottieri did five hundred years ago. While many of these actors are our "allies" —at least while the money lasts - some of them are amoral parties which can be purchased by the highest bidder while others contract exclusively for threat forces composed of the larger violent nonstate actors. ${ }^{14}$

\section{Landpower and Violent Nonstate Actors}

Landpower may be applied appropriately and inappropriately against violent nonstate actors and in their host environments at the strategic

12 This militarization of the police/bringing military concepts into policing has been both condemned and advocated. See, for example, Radley Bilko, Rise of the Warrior Cop: The Militarization of America's Police Forces (New York: Public Affairs, 2013) and Charles 'Sid' Heal, Field Command (Brooklyn: Lantern Books, 2012) respectively. Further, debates on how to best employ foreign police forces for conflict environments exist. For instance, see David H. Bayley and Robert M. Perito, The Police in War: Fighting Insurgency, Terrorism, and Violent Crime (Boulder: Lynne Rienner Publishers, 2010) and John P. Sullivan, "The Missing Mission: Expeditionary Police for Peacekeeping and Transnational Stability," Small Wars Journal, May 9, 2007, http://smallwarsjournal.com/blog/ the-missing-mission-expeditionary-police-for-peacekeeping-and-transnational-stability.

13 Robert J. Bunker, “The Mexican Cartel Debate: As Viewed Through Five Divergent Fields of Security Studies," Small Wars Journal_El Centro, February 11, 2011, http://smallwarsjournal.com/ $\mathrm{jrnl} / \mathrm{art} /$ the-mexican-cartel-debate. As violent nonstate actor forms increasingly blur and merge, we are starting to see better state forces integration.

14 Graham Hall Turbiville, Jr., "Outlaw Private Security Firms: Criminal and Terrorist Agendas Undermine Private Security Agendas.” Global Crime 7, no. 3-4 (August-November 2006): 561-582. 
level. ${ }^{15}$ Inappropriate strategic application may result in foreign policy failure and even potentially contribute to diminished US national power via open-ended conflicts which place a substantial and ongoing burden on our defense budgets. In violent nonstate actors' focused strategies, landpower forces may have a sizeable and direct role; however, the preference is to devolve the opposing actors as safely and quickly as possible for policing forces to increasingly take the lead in implementing the more encompassing strategies. These strategies are as follows: ${ }^{16}$

- Limited Punitive Strategy: Of all of the strategies directed against violent nonstate actors, this is the most limited one. It principally seeks to deter certain actions that these groups are taking or may be planning to take by means of symbolic forms of punishment directed against them. For land forces, this can range from stand-off targeting of assets and personnel for destruction (via supporting drone strikes) through the seizure or destruction of those assets and personnel via raids. An example of this strategy would be engaging in a hypothetical raid against a coastal pirate town on the Somali coast.

- Disruption and Neutralization Strategy: This can be considered a "render safe" strategy- the intent is to ensure that the violent nonstate actors have been sufficiently weakened so they are unable to export violence, such as terrorism, outside the host country or to regions of the host country not under their control. Any combination of physical assets; infrastructure, materiel, finances, personnel, and organizational cohesion; and leader and factional/cell cohesion can be targeted by means of this strategy. While a foreign terrorist organization attrited in this manner has not been eliminated, its capacity to attack US interests will be severely degraded until it is able to reconstitute itself.

- Co-option and Reintegration Strategy: The intent of this strategy is to rely on persuasion and soft power to either "buy off" (e.g., via bribes and payments) or actually reintegrate personnel into the societal mainstream by means of political enfranchisement, ideological rehabilitation, amnesty, and job training and employment programs. Rehabilitation programs have been successfully carried out in Saudi Arabia and within some other states. ${ }^{17}$ The role of land power forces within this strategy is limited with their serving more in an auxiliary security and protection role.

- Termination Strategy: This strategy seeks to eliminate a specific organization by dismantling it principally by coercive military and policing

15 A separate analysis can also be made of landpower forces applied against violent nonstate actors at the operational level. Inappropriate operational application may result in military failure and loss of indigenous population support. Applying landpower at the operational level should follow the logic of proportionality, economy of force, and network response integration with policing forces. See Steven Metz, The Future of Insurgency (Carlisle, PA: Strategic Studies Institute, U.S. Army War College, December 10, 1993) concerning the "commercial insurgency" construct and John P. Sullivan, "Transnational Gangs: The Impact of Third Generation Gangs in Central America," Air ¿ Space Power Journal (Second Trimester 2008), http://www.airpower.maxwell.af.mil/apjinternational/ apj-s/2008/2tri08/sullivaneng.htm, concerning DIME-P.

16 Army thinking is constantly evolving. Unified land operations have replaced the concept of wide spectrum operations. Proposed strategies extend the CONOPS by unifying military operations with policing operations. U.S. Department of the Army, Unified Land Operations, Army Doctrine Reference Publication (ADRP) 3.0 (Washington DC: U.S. Department of the Army, May 16, 2012).

17 See the report prepared by the International Centre for Political Violence and Terrorism Research (ICPTVR) and the Religious Rehabilitation Group (RRG), International Conference on Terrorist Rehabilitation (ICTR), February 24-26, 2009, Singapore, http://www.pvtr.org/pdf/ Report/RSIS_ICTR_Report_2009.pdf. 
activities. This requires an ongoing boots-on-the-ground presence and may require years to achieve success. This is also dependent on the size and sophistication of the targeted actor, its penetration into local society, termination strategy resources allocated, and local environmental conditions present (e.g., cross border sanctuaries). A good example was the intent of Operation Enduring Freedom in Afghanistan to eliminate al Qaeda and Taliban organizations within that host country.

Potential inhibitors of these strategies include the fact that a specific targeted actor can move to another location, or is already transnational in nature and exists simultaneously in many locations. Thus, the potential transnational existence of these threats requires the possible fielding of landpower and policing forces in multiple national locales. Additionally, some violent groups are heavily networked and exhibit a biological reconstitution capacity-like starfish growing back a lost limb-which makes them resilient to targeting. ${ }^{18}$ Unintended second and third order effects of these targeting strategies may also result in unwanted outcomes. ${ }^{19}$

Another major spoiler of these strategies is the fact that if a targeted actor is weakened or eliminated, a vacuum may develop in the host environment. This condition is readily evident in host environments in lower socio-economic regions in which the illicit economy, lack of governmental authority, and dysfunctional patterns of human organization dominate. Neutralizing or eliminating a specific gang, cartel, or warlord group simply allows for a competitor, successor, or new organization to fill the void. In host environment alteration focused strategies, the role of landpower forces is that of a facilitator-they may help to provide the domestic security conditions under which these strategies can be facilitated-but are not the primary implementers of state building or strengthening regimes. ${ }^{20}$ These strategies, integral to responding to "wars among the people" and the recognition of the human domain of warfare, are as follows: ${ }^{21}$

- Stability and Support Strategy: The intent of this strategy is to stabilize the host environment - typically a fragile or failed city, region, or state-so it does not deteriorate further. Putting an end to sectarian and violent nonstate actor violence by providing peace enforcement activities and humanitarian aid to the local populace to satisfy basic living needs (food, water, clothing, shelter, etc.) are the typical objectives. It should be noted implementation of this strategy will not fundamentally alter the host environment which will remain favorable to violent nonstate actor sustainment.

- Limited State Building Strategy: This strategy promotes the creation of

18 For more about starfish (networked) organizations, see Ori Brafman and Rod A. Beckstrom, The Starfish and the Spider (New York: Portfolio, 2006).

19 The deportations of Los Angeles street gang members in the 1990s who were illegal immigrants to Central America gave rise to the Maras (MS-13 and M-18) in El Salvador and neighboring countries.

20 In ungoverned spaces, the reality is that the military has had to fill the governance void or risk mission failure. This mission is better left to U.S. Department of State (USDOS), United States Agency for International Development (USAID), and related agencies.

21 Rupert Smith, The Utility of Force: The Art of War in the Modern World (New York: Vintage, 2008) and Charles T. Cleveland and Stuart L. Farris, "Toward Strategic Landpower," Army, July $2013,20-23$. 
a functioning and somewhat legitimate state. This result extends beyond just the protection of the indigenous people and providing for their basic survival needs. Other components of modern society will be developed to one degree or another including a functioning civil service, education and schooling, employment opportunities in the formal economy, social welfare, and entertainment and sports programs. No provision for free and democratic elections, the enfranchisement of women, or limitations on state corruption or police excesses exists. Still, the host environment created will be less favorable to violent nonstate actor sustainment than that found in fragile and failed regions.

- Democratic Capacity Building Strategy: The conceptual model behind this strategy is almost seventy years old and is derived from the American experience with post-war Germany and Japan. In both instances, authoritarian governments were unconditionally defeated and the conquered indigenous populations were "societally reengineered" over the course of decades into modern democracies. Conceptual extensions of this strategy include the reconstitution of former East Germany and other Eastern European countries into democratic states with the end of the Cold War and its attempted implementation in Iraq and Afghanistan over the last dozen years with very mixed results. ${ }^{22}$ Democratic states are viewed as producing fewer and more benign forms of violent nonstate actors than other host environments.

\section{Conclusion}

As this article has explained, landpower-in terms of conventional, general purpose formations (brigade combat teams) - is not the primary solution for contending with violent nonstate actors. In fact, given our recent experiences:

The application of military force in its current form has limited utility when fighting modern wars among the people...Strategic victory requires a wider understanding of "forces" that includes the military and nonmilitary. ${ }^{23}$

While landpower forces may indeed have a sizeable and direct role in some strategies, the better choice is to utilize policing forces-both specialized and general ones - as safely and as quickly as feasible. ${ }^{24}$ In some instances, however, specialized US Army constabulary forces may be required as an initial stabilizing force. Further, concerning host environment targeted strategies, landpower may help provide the domestic security conditions under which they can be facilitated, but it should not be the primary implementers of those conditions.

In the Iraqi and Afghani campaign theaters, lessons learned include the view that, "It takes a network to defeat a network," and "The network [our network] needed to include everyone relevant who was

22 Concerning the need to shift from the current strategy of regime change followed by stability operations see Andrew F. Krepinevich, Jr., "Strategy in a Time of Austerity," Foreign Affairs (November-December 2012): 58-69.

23 Cleveland and Farris, "Toward Strategic Landpower," 23.

24 Police forces are not only more appropriate against many violent nonstate actors, they are vastly cheaper to field and sustain than landpower forces. 
operating within the battlespace." ${ }^{25}$ Such networks have been coordinated principally by the US military and portray the entrepreneurship and adaptability of our landpower forces in the face of new and evolving nonstate threats. Still, as has been discussed, larger strategic issues are now in play. Our recent campaigns have taken us into conflicts that were fertile, such as Afghanistan, or became fertile, such as Iraq, host environments for violent nonstate actor emergence and sustenance. We are also observing these host environments emerge in former autocratic states such as Mexico, Libya, and Egypt, and in potentially transitioning ones such as a Syria gripped by civil war. In a sense, two paths from autocracy now exist - the preferable and hoped-for democratic one and the one dominated by violent nonstate actors who fill the vacuum of governance vacated by former institutions of an autocratic state.

The attempted transition of autocratic states is indicative of the major issues at hand. Intervening states deploying land and policing forces are increasingly finding themselves in a dilemma when confronting violent nonstate actors. Focused strategies are actor-specific and even when that actor is eliminated or reintegrated into the political process, a successor or new actor typically emerges. Host environment alteration strategies, on the other hand, are meant to alleviate the conditions under which these actors breed and grow. These strategies exist at a level beyond the use of land and policing forces and seek to engage in societal reengineering in failed, fragile, and transitioning states. US governmental programs to facilitate any form of limited state-let alone democratic capacity_-building have not been up to the monumental tasks required, even when flush with monies. As a result, US attempts at both eliminating violent nonstate actors and denying them host environments have been mostly studies in failure.

This fact brings us back to the contemporary problem we now face. Our recent attempts at "democratic capacity building" in host environments have been far from successful and-given the age of austerity faced by the United States Army, its sister services, and the United States government writ large-we no longer have the resources nor the political will to engage in such long-term and expensive endeavors. This reality suggests that strategic victory in some of these environments is presently unattainable. To conserve finite elements of national power, more cost-effective forms of counter strategies-based on some form of global violent nonstate actor containment and mitigation protocolshould be considered. 



\title{
Confronting Africa's Sobels
}

\author{
Robert L. Feldman and Michel Ben Arrous \\ (C) 2013 Michel Ben Arrous
}

\begin{abstract}
AвSTRACт: While the phenomenon described in this article may appear to be an African problem, the Western world's increasing involvement in fighting terrorists make it one that America's military forces might encounter. Unfortunately, it could add a significant layer of complexity to US operations as American troops attempt to differentiate allies from enemies. In Africa, sometimes they are one and the same.
\end{abstract}

obel, a portmanteau of "soldier" and "rebel," appears to have been coined in Sierra Leone during the 1990s. This was a period marked in parts of West Africa by fighting over conflict diamonds, also known as blood diamonds, when government soldiers discovered how lucrative it could be to serve as "soldiers by day, rebels by night" or, as the villagers called them, "sobels." On closer examination, it can be observed that the relationship between the soldiers of the Sierra Leonean Army and the Revolutionary United Front (RUF), the rebel group which during the country's civil war occupied large portions of diamond-rich land, changed over time, thus making the sobel phenomenon more like the sobel phenomena.

Unfortunately, the presence of sobels is often an indication that a war is profitable for both rebels and soldiers, providing them with an incentive to lengthen the conflict to maximize their earnings. With neither side able to score a decisive win, both sides profit. Meanwhile, the rural population, essentially held hostage during the conflict, is often terrorized so as not to intervene. As an example, the RUF started not only to amputate people's hands, but to publicize such mutilations as a way of preventing people from casting ballots and putting a political end to "unpolitical" brutalities.

Though Sierra Leone appears to be where the "sobel" neologism originated, variations of the soldier-by-day, rebel-by-night phenomenon can be found in many parts of Africa (and, indeed, in other parts of the world). By studying the sobel phenomenon and its variations, it is possible to determine what factors influence government soldiers to join rebel forces, ways to dissuade them from joining, and, if they do join, possible ways to induce them to return permanently to government service.

While the sobel phenomenon described within these pages may appear to be an A frican problem, the Western world's increasing involvement in fighting terrorists on that continent make it one America's military forces might encounter. Unfortunately, it could add a significant layer of complexity to US operations as American troops attempt to differentiate allies from enemies. In Africa, sometimes they are one and the same. 


\section{Background to Sobel: The Sierra Leone Civil War}

Sierra Leone's civil war started in 1991, when the RUF, led by Foday Sankoh, and backed by Liberian warlord Charles Taylor, launched an attack in a diamond-rich area in Eastern Sierra Leone. ${ }^{1}$ Though ostensibly the RUF's raison d'être was to oppose the corrupt government, it morphed more into a group of bandits and less a band of revolutionaries. As for Taylor, who later would become President of Liberia, his interests from the outset appear mostly financial.

The war lasted eleven years, during which time both the RUF and the army were responsible for heinous atrocities against civilian populations. Estimates of the number killed range upwards of $50,000 .{ }^{2}$ It took foreign intervention, in particular the country's former colonial power, the British, to help end the war.

\section{Atrocities as a Contributing Factor}

There were many factors which led to some of Sierra Leone's soldiers becoming sobels, including several socioeconomic ones discussed later. A significant driving force, however, was the civilian hatred of the army because of the atrocities the soldiers committed fighting the RUF. The soldiers, when willing to hunt down the RUF-an inconsistent process as the army was sometimes afraid of direct combat with the rebels-often had difficulties locating their enemy. Frustrated, they would brutalize citizens suspected of being RUF members or sympathizers. Additionally, when the army would recapture a town, it would sometimes relocate the population in a program reminiscent of the hated "strategic hamlet" initiative of the Vietnam War.

The soldiers' actions generated a great deal of hatred on the part of the mistreated people; some even joined the RUF. Being hated by the civilian populace caused the already low morale among the soldiers to sink even further. Eventually this low morale, combined with low government rations, convinced the soldiers that instead of fighting the villagers - who fought back at their mistreatment-it was more lucrative to join the rebels in looting civilian populace. ${ }^{3}$

\section{Socio-Economic Factors}

Particularly interesting with regards to the sobel phenomenon in Sierra Leone were the socioeconomic differences between the initial rebel recruits and the army recruits: there were none. Both the RUF and army "recruited from the same social stratum, the underprivileged youth of Freetown, who had often gone to the same schools with no job prospects, and shared the same revolt." This shared background and these common ties likely made it more difficult for the soldiers to view the rebels as true enemies. Combined with poor training, poor pay, and

1 Lansana Gberie, A Dirty War in West Africa: the RUF and the Destruction of Sierra Leone (Bloomington: Indiana University Press, 2005), 6 .

2 “Sierra Leone," GlobalSecurity.org, 26 Apr 2012, http://www.globalsecurity.org/military/world/ war/sierra_leone.htm

3 Lansana Gberie, A Dirty War in West Africa, 102.

4 Michel Ben Arrous and Robert Feldman, "Understanding Contemporary Conflicts in Africa: A State of Affairs and Current Knowledge," Unpublished Manuscript, January 2013. 
little esprit de corps, there was no mental barrier to breach for the soldiers to see themselves as helping or becoming rebels.

The Sierra Leone experience demonstrates the difficulties inherent in quelling a rebellion with soldiers cut from the same cloth as rebels. Often, opposing forces try to demonize or dehumanize the other side, perhaps making it psychologically easier to kill. It is difficult for soldiers, however, to dehumanize the enemy when as youngsters they lived and played together.

To be sure, not all African nations have armies composed of people from the same location and socioeconomic background as rebel groups. In instances where they are different, and frequently that difference is ethnicity, the opposing forces appear more likely not only to fight but to brutalize each other. Press reports from Africa are filled with stories of human rights abuses, including descriptions of activities bordering on, or maybe even crossing into, ethnic cleansing by soldiers and rebels alike.

One must remember that Sierra Leone soldiers were not defending their families from attack. The military mission was far from home, so there was no added sense that failure to destroy the RUF would be personally disastrous. For that matter, there was also no sense that joining the rebels, even temporarily, would endanger families back home. If anything, the converse was probably true: joining the rebels was a way for the soldiers to enrich themselves and, in turn, their families.

Finally, with regards to the socioeconomic factors leading to the sobel phenomenon, one must remember the long tradition in many African countries of both rebels and governments recruiting, voluntarily or forcibly, children into their ranks. These young rebels and soldiers, who are still quite impressionable, easily swayed by peer pressure, and usually followers rather than leaders, can readily and perhaps even effortlessly switch sides when those around them are doing so.

\section{Evolution of the Sobel}

It is difficult, if not impossible, to ascertain the exact date sobels first emerged in Sierra Leone. But certainly by 1993 government soldiers had begun their ruse of dressing as RUF fighters at night and attacking villages. As these nocturnal soldiers-turned-rebels retreated, they would leave weapons and ammunition for the "real" RUF rebels who, in turn, would also terrorize and pillage the villages. With daybreak, the army, now in uniform, would appear, offering protection from the rebels ... for a price. Eventually, the army developed ways to supply the rebels even during daylight, such as prearranging a rebel ambush and losing a truck laden with military equipment.

Sobels and real rebels coordinated attacks to avoid fighting each other. Finding an isolated village, they would take turns terrorizing and pillaging it, ensuring both were not there at the same time and avoiding the possibility they would accidentally come to blows.

Adding to the confusion of who attacked a village-soldiers or rebels-were rebels who conducted raids in stolen army uniforms. ${ }^{5}$ Thus, it worked both ways: actual soldiers dressing as rebels at night

5 "Revolutionary United Front," GlobalSecurity.org, http://www.globalsecurity.org/military/ world/para/ruf.htm 
(the sobels), and actual rebels dressing as soldiers. Poor communications from the region, in conjunction with a lack of independent confirmation, probably did little to help clarify which group, soldiers or rebels, actually carried out an attack.

The sobels, during these and other attacks, were particularly brutal. From a philosophical standpoint, perhaps this fact can be attributed to the ideological void left by the exhaustion of grand narratives such as nationalism, pan-Africanism, African socialism, and others. Lacking both the analytical tools to understand their own underprivileged status and a coherent agenda to redress it, they were more prone to extreme levels of brutality than a soldier or a rebel clearly standing on either side. In this regard, the sobel phenomenon could also be read as a product of current ideological disenchantment.

\section{Sobels and Sierra Leone's Military Junta}

Sierra Leone's ruling military junta, the National Provisional Ruling Committee (NRPC) ironically benefitted, at least initially, from these soldiers who would betray their government and periodically join the rebels. The junta explained they were anxious for a return to democracy, but could not relinquish power until the RUF was defeated and the country was at peace. Such proclamations created the appearance that the NRPC had the country's - as opposed to their own-interests at heart. However, like many juntas, once in power their desire was to stay in power. The troops, by failing to defeat the RUF and increasing the number of RUF rebels by periodically and clandestinely becoming rebels themselves, created enough concern that the NRPC declared it was not yet safe for a return to civilian rule.

Having soldiers periodically join the rebels and share in their profitable ventures had another benefit for the military officials. As happens in many African militaries, conditions in the field for lower-ranking troops can be miserable. Irregular and meager pay contributed to the conditions for mutiny against superior officers. By allowing these soldiers to join the rebels, mutinies and perhaps even coups were avoided.

Eventually the sobel phenomenon was exposed, and the NRPC, under pressure, admitted that at least 20 percent of the government troops were disloyal. ${ }^{6}$ The exact percentage is unknown, but, given the economic incentives to share in the rebels' profits, the lack of oversight from the military junta (who benefitted from the sobel phenomenon), and the familiarity of troops with the rebels (since they had both come from the same social stratum), it would not be surprising if the percentage of troops serving as rebels was much higher than the 20 percent claimed by the NRPC.

Knowing a percentage of his troops were disloyal, and realizing his military was incapable of securing the diamond areas from the RUF, Sierra Leone President Captain Valentine Strasser turned to a private military company, Gurkha Security Groups, for help in 1995. Largely comprised of Nepalese ex-British army troops, they were led by an American, Robert

6 Lansana Gberie, “The May 25 Coup d'Etat in Sierra Leone: A Militariat Revolt?” African Development 23 (3-4): 149-70.

7 Simon Akam, "The Vagabond King," New Statesman, February 2, 2012, http://www. newstatesman.com/africa/2012/01/sierra-leone-strasser-war 
MacKenzie. Unfortunately, MacKenzie, along with Strasser's aide-decamp, Abu Tarawalli, were ambushed and killed. Strasser then turned to a South African-based private military company, Executive Outcomes, whose success in combating the rebels is described below.

\section{From Rebels to Soldiers to Rebels}

While not quite the sobel description of soldier by day and rebel by night, a related phenomenon is apparent in several other parts of Africa. Former rebels integrate into government armies and then revert to rebels at a later date. An excellent example can be found when examining the recent history of the Tuareg, a traditionally nomadic people who live in the Sahara and northern Sahel of Mali and Niger. There have been several Tuareg insurgencies, detailed descriptions of which are beyond the scope of this article; however, these conflicts were often over issues such as the Tuareg feeling slighted by central governments regarding sharing of wealth from minerals mined in Tuareg regions. Peace treaties to end these rebellions often included an agreement to integrate the former rebels into government militaries. However, sometimes these rebels-turned-soldiers became disenchanted with the army or the way fellow Tuareg were treated, resulting in many deserting the military and returning to being rebels. ${ }^{8}$

This Tuareg changeover between rebel and soldier contains elements of the sobel phenomenon: the possibility exists that whatever state-rebel or soldier-the Tuareg or the Sierra Leoneans are in, they are capable of changing; that change can be relatively easy, and when the change occurs, it is frequently removed from oversight by the central government.

Clearly there are also some differences between the sobel phenomenon and the Tuareg rebel-soldier-rebel changeover: while the sobels change daily, the Tuareg rebel-soldier-rebel transition can be measured in months. Another difference is the Sierra Leoneans continue to cycle between soldier and rebel, whereas the Tuareg seemingly stopped at rebel, though this might yet change again if there is another attempt to bring more Tuareg into the army. However, these and other differences should not obscure the most noteworthy similarity: both can leave governments and foreign analysts guessing as to the true strength and loyalties of the rebels and military forces.

Adding to the confusion of estimating the strength of various forces is the contradictory nature of information regarding rebels and soldiers who switch. An infamous but uncorroborated claim of Tuareg defections from the army occurred during one of the Tuareg rebellions. 'The Mouvement des Nigériens Pour la Justice (the Nigeriens Movement for Justice or MNJ), a mostly Tuareg-based group in northern Niger fighting for greater revenue sharing from uranium mining, claimed an entire special forces unit, the Niger Rapid Intervention Company, which had been trained by the American military, defected in 2007. The government, though acknowledging some desertions, denied they had occurred en masse. Other unsubstantiated claims have also been made regarding this

8 “Tuareg Rebels Leave Mali Town,” BBC News, May 24, 2006, http://news.bbc.co.uk/2/hi/ africa/5008224.stm

9 "NIGER: Five Killed as Army Clashes with Tuaregs in Desert North, "IRIN News as carried by GlobalSecurity.Org, October 7, 2004, http://www.globalsecurity.org/military/library/news/2004/10/ mil-041007-irin02.htm 
unit. Such claims and counterclaims in regions where it is hard to document the truth underscore the difficulties in assessing the magnitude of "soldier by day, rebel by night" and related phenomena.

\section{Private Military Companies as a Possible Solution}

One suggestion to avoid risking soldiers becoming rebels is to outsource the army; in other words, hire private contractors to provide security. Indeed, there have been some successes with private military companies, perhaps the most notable one in Africa with the aforementioned Executive Outcomes, which successfully wrested control of the diamond fields from the RUF in the mid-1990s, eventually forcing a negotiated peace between the rebel organization and the government. Further evidence of the superiority of private military companies to at least some African peacekeeping forces was provided when Executive Outcomes, under international pressure, was compelled to leave. ${ }^{10}$ Unfortunately, it was replaced by an ineffective United Nations (UN) peacekeeping force; the RUF soon returned with a vengeance, implementing Operation No Living Thing, aptly named, as many were mutilated or killed in a butchering spree that reached all the way to the capital, Freetown. ${ }^{11}$

As evidenced by the pressure on Sierra Leone to stop using Executive Outcomes, there is substantial animosity by African leaders and governments against the employment of private military companies. Several reasons for this animosity are as follows:

- The embarrassment that African militaries are incapable of handling internal security issues.

- The appearance of neocolonialism if troops from another country, even if the other country is African, are brought in. Executive Outcomes may call themselves a private military company, but to many Africans they are mercenaries, and Africa's long and bitter history with mercenaries-especially white mercenaries - used by colonial powers is not forgotten.

- The potential loss of income to African militaries because the UN pays governments to supply peacekeepers. By not allowing private military companies, the UN is essentially forced to use African militaries, providing a lucrative source of revenue for those countries which furnish the troops.

- The concern that mercenaries are not bound by the laws of states as private military companies fall outside the normal chain of command. They could be used as a tool against political opponents and may "fight in a non-regulated, wanton fashion." 12

- The belief that employing private military companies dissociates the technical aspects of security from the legitimacy, or lack thereof, of the government. As a result, such companies are unable to provide

10 Simon Akam, "The Vagabond King."

11 Catherine Hawley, “A Country Torn by Violence,” BBC News, January 12, 1999, http://news. bbc.co.uk/2/hi/special_report/1999/01/99/sierra_leone/251377.stm

12 Mayank Bubna, "The Case for Mercenaries in Africa," Institute for Defense Studies and Analysis, June 1998 http://www.idsa.in/system/files/IB_MercenariesinAfrica.pdf 
long-term solutions to problems required by a political process.

Despite the concerns and protestations of some African leaders regarding the use of private military companies, there are others who call not only for their use but also for their compensation based on outcomes. There are also those in the middle, looking at security needs in various regions but unsure if private military companies should fill them. This tenuous outlook is perhaps best exemplified in a statement by former UN Secretary General Kofi Annan regarding the Rwanda genocide during the time he was head of the UN Department of Peacekeeping Operations: "When we had need of skilled soldiers to separate fighters from refugees in the Rwandan refugee camps in Goma, I even considered the possibility of engaging a private firm. But the world may not be ready to privatize peace." 13

\section{Conclusion}

There appears to be a tradeoff with regards to recruiting soldiers from the same location and social stratum as where the rebels recruit. In this situation, the soldiers generally appear to be less likely to commit atrocities against the rebels. The tradeoff is the soldiers are likely to be less effective at putting down the rebellion and, in fact, may even serve as part-time rebels themselves. The converse also appears true. While having soldiers who are significantly different from the rebels enhances the likelihood they will actually engage them in combat, it increases the risks for the commission of atrocities - on both sidesduring the fighting. Certainly there are exceptions. Depending on the location, additional factors may alter these generalizations; however, those who have spent time in Africa can attest to both the close ties within ethnic groups and the frequent animosity among ethnic groups. In Sierra Leone the soldiers joined the rebels; in some African countries the soldiers massacre the rebels.

Perhaps the step an African nation can take which would have the greatest impact on preventing soldiers from serving with the rebels is for the government to get its own house in order. Corruption is contagious, and it is probably unreasonable to ask soldiers to risk their lives for a few dollars a month while officials, far removed from the fighting, live in splendor. Additionally, by having a legitimate and at least minimally effective government, one that appears to be trying to make a better life for its citizens, soldiers may feel more committed to serving the nation honorably.

Related to the government being effective is the need for it to be competent when it sets domestic and foreign policy objectives. Irrational objectives which antagonize ethnic groups within the country or governments of neighboring countries, or which dedicate disproportionate amounts of money to projects of questionable benefit, or any of the other untold numbers of dubious policies, are often an obstacle to developing a sense of nationalism. Having rational policy objectives will help obtain commitment from soldiers who see benefits to the citizens.

Unfortunately, there are numerous African governments which are largely corrupt, grossly ineffective, or both. It is hard to be cynical

13 Kofi Annan, "Thirty-Fifth Annual Ditchley Foundation Lecture," UN Press Release SG/ SM/6613, 26 June 1998. 
about soldiers who decide to moonlight as rebels when the government is enriching itself at the expense of the people or directing that only certain groups, inevitably tied to the politicians in office, benefit handsomely from government largesse while others receive nothing.

African nations can take several actions to minimize the likelihood their troops will become sobels. These include:

- Improving pay for troops so there is less incentive to supplement their income.

- Improving training for troops so there is a greater sense of professionalism. Especially important in this training is an emphasis on human rights. As stated earlier, one of the reasons soldiers became rebels was because they were already battling the villagers whom they had abused.

- Developing and enforcing regulations against children serving as soldiers.

- Improving command and control of African troops.

- Setting clear expectation of military objectives in operations against rebels, and, along these lines, clear rules of engagement.

- Utilizing private military companies, at least in part, for operations where there might be strong incentives, such as in diamond-rich areas, for soldiers to become sobels. This measure does not guarantee private military company mercenaries will not illegally enrich themselves, but often these companies have better control over their employees than African militaries do over their troops.

- Stating clearly soldiers are prohibited from serving with the rebels and offering strong, though humane, punishments for those who do.

The reader might note that foreign military assistance could be valuable in helping African nations implement some of these suggested courses of action. United States Africa Command (AFRICOM) could take a role in improving command and control, raising the quality of training, and assisting in the development of clear military objectives. An additional, though significantly more controversial, action would be the use of unmanned aerial vehicles, drones, to monitor African troops to ensure they perform in a professional manner. These initiatives could make a tremendous difference, relatively inexpensively, with a small footprint on the ground and not in combat. Of course, an AFRICOM venture is not risk free . . . adverse outcomes are definitely a possibility. The potential benefits that would accrue from the cessation of a percentage of African soldiers in certain countries not engaging in rebel-like activities need to be weighed against potential costs_-including the possibility of American deaths_ of US involvement, even if limited to advising.

When discussing whether to utilize AFRICOM, one must remember that benefits from such a venture would accrue not just to African countries but to other nations as well, including the United States. America, especially in helping to decrease abuses by African soldiers, could improve its image not just in African countries with important mineral resources but throughout much of the continent. Additionally, more professional African militaries could mean more stable countries, resulting in better investment opportunities for American companies previously hesitant to enter certain regions because of dangers involved. 
The existence of stable African coastal nations decreases the likelihood of pirates launching from their shores and interfering with international shipping. Such benefits, while appealing, are only potential, and unanticipated consequences to interventions are always a possibility, a problem amplified by the vagaries of African ethnic and political rivalries.

Though some actions to turn the sobel phenomenon around may be fairly easy to implement, such as providing clear rules of engagement, others, such as improving a nation's governance, are far more difficult. Therefore, in the long run, expect the sobel phenomenon and its variants to continue, making it difficult at times for American military operations to distinguish allies from enemies. As stated earlier, in Africa sometimes they are one and the same.

\section{Robert L. Feldman}

LTC Robert Feldman, USAR, is an analyst with the Foreign Military Studies Office, Fort Leavenworth, KS. His main areas of research include terrorism, counterterrorism, and human security in Africa. He has published in numerous peer-reviewed journals and regularly serves as a subject matter expert on African security and stability for various Department of Defense activities.

\section{Michel Ben Arrous}

Mr. Michel Ben Arrous is a geographer with teaching and research interests in political geography, cultural studies, and the history of geographic ideas. An architect by training, and a former journalist in Southern and West Africa, he is the author or editor of eight books, including co-author of African Studies in Geography from Below (Dakar: CODESRIA, 2009). 



\section{Waging Financial War}

\author{
David J. Katz \\ (C) 2013 David J. Katz
}

\begin{abstract}
AвSTRACT: Has the emergence of global financial markets brought with it global financial warfare? This article discusses the canon of financial warfare and how one might wage it across both the strategic and tactical realms.
\end{abstract}

magine warfare waged in financial cyberspace: electronic, remote, fought in hypervelocity with millions of engagements per second, and with nations forced to construct redundant systems, sacrificing billions in economic efficiency for survival capacity. Financial warfare strikes can blockade vital industries; delink countries from the global marketplace; bankrupt sovereign economies in the space of a few days, and cause mass exoduses, starvation, riots, and regime change.

Financial warfare can support US policy objectives by attacking regime elites, collapsing trade, draining foreign currency reserves, decreasing economic production, spiking inflation, driving unemployment, increasing social and labor unrest and accelerating population migration. Financial warfare can assist the warfighter by halting an enemy's capability to produce and distribute war materials, fund training, operations, or proxies. Financial warfare can amplify and accelerate the damage inflicted by economic warfare. Financial warfare spoofing operations can assist intelligence collection by isolating and mapping crisis response patterns of individual adversaries, organizations, nations, and regime elites.

The aim of financial warfare is, quite literally, to disarm opponents by reducing their ability to finance production or distribution, complete transactions, or manage the consequences of a transaction failure. If precisely employed, financial warfare can reduce a targeted society's will and cohesion by forcing upon it, in stark terms, the daily necessity to choose between "guns" or "butter." This dilemma highlights and magnifies the real, immediate, and personal consequences of resource allocation. Deployed within an indigenous society's political framework, financial warfare can deepen the divide between rival constituencies, reducing societal cohesion and inciting civil unrest.

Financial warfare is not a new concept. While many individual policy actions had financial aspects, perhaps the first pure financial warfare campaign in United States history occurred in the Eisenhower administration. It was prompted by the Soviet invasion and suppression of the Hungary Revolution on 4 November 1956 and sparked by the seizure of the Suez canal by NATO allies, Britain and France, in Operation Musketeer on 5 November. ${ }^{1}$ President Dwight Eisenhower determined he could not effectively oppose Soviet military intervention

1 Malcom Byrne, Csaba Békés, János Rainer, eds. The 1956 Hungarian Revolution: A History in Documents, (New York, N.Y., Central European University Press, 2002): 1, http://www.gwu. edu/ nsarchiv/NSAEBB/NSAEBB76/
Mr. David Katz is a 1981 West Point graduate and served in Europe, the United States, and Central America. After obtaining an MS from Carnegie Mellon, he became an institutional investor in private equity and founded his own firm providing guidance on over $\$ 3$ billion of client equity investment. Currently, he is a global finance specialist and senior staff member in SRA's Intelligence Practice. 
in Hungary, while allowing European military intervention in Egypt. ${ }^{2}$ Diplomacy had not convinced the British or the French to withdraw. ${ }^{3}$ The United States was hesitant to intervene with military force against NATO allies. As an alternative, Eisenhower employed financial warfare. With just three offensive strikes, the United States achieved its immediate policy aims of forcing Britain and then France to withdraw from the Suez Canal. The three financial warfare strikes were: (1) blocking the International Monetary Fund (IMF) from providing Britain with $\$ 561$ million in standby credit; (2) blocking the US Export-Import Bank from extending $\$ 600$ million in credit to Britain; and (3) threatening to dump America's holdings of pound-sterling bonds unless Great Britain withdrew from the Suez. ${ }^{4}$ The credit blockade froze Britain's ability to borrow and forced it back onto its negative cash flow, effectively bankrupting it. The pound-sterling threat significantly raised the perceived risk of dealing in British currency. That threat, if executed, would have directly affected British ability to trade internationally.

By 1956, Britain was grossly overleveraged and dependent on further international borrowing to maintain its standard of living. The United States owned $\$ 3.75$ billion in British debt as a result of the Anglo-American Loan Agreement of 1945, while the entire foreign currency reserve of Britain in October 1956 was equivalent to $\$ 2.2$ billion. $^{5}$ To finance its WW II efforts, Britain had borrowed extensively from Commonwealth members and by 1945 owed roughly $£ 14$ billion, chiefly to India, Argentina, and Egypt. Unable to repay in full, Britain froze the principal balances in these accounts.

The sell-off of US-held pound-sterling bonds, if executed, would have been catastrophic. The resulting increase of British currency in circulation would have deflated the value of the pound-sterling. This deflation would, in turn, have required Britain to drain its foreign currency reserves to buy pound-sterling bonds to maintain its currency's parity against the US dollar. If it broke parity, and allowed the devaluation of its currency, Britain would not have the purchasing power or the foreign reserves to cover its food and energy imports. Additionally,

2 Peter L. Hahn, "Significant Events in U.S. Foreign Relations: 1900-2001," EJournalUSA (Washington, D.C.: US Department of State, 2006): 26-30, www.america.gov/media/pdf/ejs/ ijpe0406.pdf; "Interview with General Andrew J. Goodpaster," George Washington University's National Security Archive, http://www.gwu.edu/ nsarchiv/coldwar/interviews/episode-8/goodpaster1.html. Eisenhower's aide, General Andrew Goodpaster, recalled that Eisenhower's staff thought NATO could not present a united front to Soviet aggression in Hungary while Britain and France were occupying Suez; Byrne and Békés, Hungarian Revolution.

3 "Memorandum of a Conference with the President, White House, Washington, October 29, 1956, 7:15 PM," Office of the Historian, US Department of State, http://history.state.gov/historicaldocuments/frus1955-57v16/d411; "Message from President Eisenhower to Prime Minister Eden," US Department of State, Office of the Historian, Washington, October 30, 1956, http:// history.state.gov/historicaldocuments/frus1955-57v16/d436;

4 James M. Boughton, "Was Suez in 1956 the First Financial Crisis of the Twenty-First Century?” Finance and Development 38, no. 3 (September 2001): 1, http:/ / www.imf.org/external/ pubs/ft/fandd/2001/09/boughton.htm; Rose McDermott, Risk Taking in International Politics (Ann Arbor, MI: University of Michigan Press, 2001), 162, http://www.press.umich.edu/ pdf/0472108670-06.pdf .

5 Nicholas Miller Trebatk, "The United States, Britain and the Marshall Plan: An analysis of Anglo-American relations in the early postwar era," Paper presented at XII Conference on Contemporary Capitalism and the National and Political Economy of Brazil and Latin America on Contradictions and Perspectives, Rio de Janeiro, Brazil, 2007. The author was a doctoral student at the Instituto de Economia, Universidade Federal do Rio de Janeiro (IE-UFRJ); Adam Klug and Gregor W. Smith, "Suez and Sterling, 1956," Working Paper No. 1256 (Kingston, Ontario, Canada: Queen's University Economics Department, 2nd Quarter, 1999), Figure 3: Britain's reserves: 36, http://www.econ.queensu.ca/working_papers/papers/qed_wp_1256.pdf 
Commonwealth account holders would probably have withheld further credit until all prior debts were settled. Without credit, Britain would have faced a prolonged liquidity crisis and insolvency.

In his response to the Suez Crisis, Eisenhower waged a modern financial warfare campaign. Without credit-fueled deficit spending, Britain could not import needed oil and food. It would also have destroyed Britain's trade and its ability to form capital through trade surpluses, and collapse its ability to import goods at a deficit to maintain its standard of living. These financial strikes operated beyond US legal jurisdiction and where informal US influence had failed. Eisenhower's actions were outside conventional or irregular war. Financial warfare thus supplanted traditional warfare in countering the British and French seizure of the Suez Canal.

This Suez Crisis example illustrates the importance of understanding the offensive capabilities and defensive necessities of financial warfare. The United States successfully waged financial warfare against the third most powerful nation on the planet at that time; it is likely the United States will be targeted by financial warfare in the future.

\section{What is Financial Warfare?}

Historically, financial depredation has been at best a subsidiary effect of economic warfare. That has changed. With the emergence of integrated global financial markets, financial warfare has become a viable, distinct, and independent means of projecting power. As Yale Professor Paul Bracken explained: "The economic system deals with the hard and soft outputs of the economy-that is, goods and services. The financial system deals

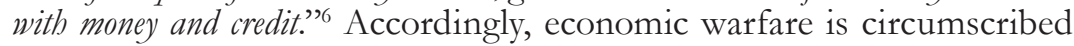
to attacks on the enemy's ability to produce and distribute goods and services; financial warfare is confined to attacks on the credit and monetary foundations that underlie production and distribution. Financial warfare is a potent means of power projection because precluding a nation's ability to price and to exchange; to form capital and manage risk; causes production and distribution to cease. Without production and distribution, the economy grinds to a halt and the adversary is disarmed. Financial warfare thus uses money and credit to attack (defend) an opponent (or a friend).

In practice, financial warfare identifies systemic areas of opacity, agency and asymmetry in information, risk and reward; focuses on those areas with a high relative degree of centralization and leverage; and determines the ranges of integration and diversification that offer the greatest susceptibility to contagion and cascade failure. ${ }^{7}$ Offensive financial warfare seeks to engineer outcomes from altering adversary capabilities to creating "Black Swans," which are large-scale events of massive consequence that occur far from the means of statistical

6 Paul Bracken, "Financial Warfare," Foreign Policy Research Institute (2007): 4, http://www.fpri. org/enotes/200709.bracken.financialwarfare.html; Text is paraphrased from "Financial Warfare," page 4. as originally published in Orbis, Fall 2007 edition.

7 Constantine Sandis and Nassim Taleb, "The Skin in the Game Heuristic for Protection Against Tail Events," Social Science Research Network, July 30, 2013, 1, http://papers.ssrn.com/sol3/papers. cfm?abstract_id=2298292 ; Nassim Taleb, Antifragile: Things that Gain from Disorder (New York: Random House, 2012); Matthew Elliot, Benjamin Golub, Matthew Jackson, "Financial Networks and Contagion," Social Science Research Network, January 1, 2013, 2-5, 16-26, http:/ / papers.ssrn.com/ sol3/papers.cfm?abstract_id $=2175056$ 
distributions (fat-tailed events) and accordingly are unpredictable and irregular. ${ }^{8}$ Defensive financial warfare seeks to decentralize; de-lever; reduce opacity, asymmetry, and skewness; or construct extra capacity, strength, and layers of redundancy to negative outcomes. The intent of financial warfare is to extend the strategic and tactical engagement of the enemy from the kinetic battlespace to the financial marketplace. It engages an opponent's financial structure, or operations, by using the three principal functions of finance: capital formation, capital liquidity, and risk-management:

- Capital formation is the accumulation of real capital surpluses through public and private savings and borrowings to create or expand future economic activity.

- Capital liquidity is the transaction of capital assets at volume, rapidly without loss of value, between buyers and sellers and among its forms, e.g., commodities to currencies, dollars to yen, stocks to bonds, etc.

- Risk management is the process of optimizing exposure to financial volatility. ${ }^{9}$

Financial warfare engagements occur at both the tactical and strategic levels. Tactical wins, losses, and draws must be used coherently to advance strategy. In financial warfare, there is an added dimension best articulated through the concept of micro and macro. A micro financial engagement is the singular use of one functional avenue, capital liquidity, capital formation, or risk management, to affect a single transaction. Macro financial engagements typically occur at system integration points between an adversary and the global, bilateral, or multilateral markets. For example, terminating Protection and Indemnity (P\&I) insurance for one ship precludes its use for hauling third party cargo internationally. This is a micro risk-management engagement. Removing an entire country's P\&I insurance uses a macro risk-management engagement to shut down a nation's international, commercial maritime cargo industry. The difference lies in whether the exploitation of vulnerabilities is individual or systemic, and whether the exploitation occurs within a system or at the interface between systems.

If global finance is an inescapable component of global trade, then its corollary_-global financial warfare-is equally inescapable. Every country involved in the global markets has, by necessity, harmonized in some degree at both the micro and macro levels with global financial standards and structures. These harmonized international standards are vital to the proficient and efficient functioning of global trade, which, in turn, is crucial to most national economies. The flipside of that coin is that these harmonized standards offer avenues of approach to wage financial war.

\section{Waging Financial War}

The recent and enormous growth of global financial markets illustrates the reach of purely financial actions. For example, the average

8 Sandis and Taleb, "The Skin in the Game Heuristic for Protection Against Tail Events," 1; for a more detailed explanation of "Black Swans" see Nassim Taleb, The Black Swan: The Impact of the Higbly Improbable (New York: Random House, 2007).

9 Philippe Jorion, Value at Risk (New York, NY: McGraw Hill, 1997), 3-15. 
daily turnover in the foreign currency exchange markets (Forex) is over $\$ 4$ trillion. ${ }^{10}$ As such, the Forex daily turnover is greater than the annual domestic product of 215 of the world's 220 countries. ${ }^{11}$ Financial warfare's capabilities and impact will only increase as global financial markets grow. With its high-speed, complex interconnectivity, and the volume of capital moving daily, warfare in the financial marketplace possesses the capability to operate separately from and at speeds far beyond economic, conventional, or irregular warfare.

The United States possesses a discrete and immense capacity for financial warfare. As the provider and guarantor of the world's reserve currency, the United States occupies a unique position in global financial markets. The reach of US currency is global. The Federal Reserve estimated that 60 percent of total US currency in circulation, roughly $\$ 450$ billion, is held outside the United States. ${ }^{12}$ Accordingly, the United States is the preeminent market for raising as well as investing capital. By 2010 , foreign borrowers had $\$ 2.1$ trillion in debt outstanding from US sources..$^{13}$ In the period 2003 to 2007,55 percent of all highly rated US securities, treasuries, agencies, and AAA-rated private debt issued, $\$ 4.5$ trillion, were purchased by foreign entities. ${ }^{14}$

From a policy perspective, financial warfare makes sense because it makes policy options available through finance that were previously obtainable solely through armed force; for example, these options could include ending effective and efficient Saudi financial support to international jihad; reducing Iranian defensive capability; and constraining Chinese economic penetration into Africa.

For uniformed military leaders, preparation of the battlespace now includes informational, cyber, economic, and financial actions. War plans can and should substitute financial-based risk for manpowerbased risk when more efficient or effective. For example, uniformed military leaders may consider the use of structured analytics like Critical Factors Analysis (CFA) to identify the centers of an adversary's defensive capabilities and target them as well as supporting components of the adversary's military-industrial base with financial strikes prior to airstrikes. The warfighter now has the choice whether to bankrupt, bomb, or both. Lastly, commanders in Unconventional Warfare (UW) and Stability Operations (SO) wield enormous financial clout within their area of operations. They must use financial warfare to erode adversary

10 Bank for International Settlements, "Triennial Central Bank Survey of Foreign Exchange and Derivatives Market Activity in 2010 - Final Results," December 1, 2010, 6.

11 Central Intelligence Agency, 2011 World Factbook, "Country Comparison: GDP (Purchasing Power Parity)," https://www.cia.gov/library/publications/the-world-factbook/ rankorder/2001 rank.html? countryCode $=x x \&$ rankAnchorRow $=\# \mathrm{xx}$

12 United States Department of the Treasury, The Federal Reserve Board. "The Use and Counterfeiting of United States Currency Abroad, Part 3, The Final Report to the Congress by the Secretary of the Treasury, in consultation with the Advanced Counterfeit Deterrence Steering Committee, pursuant to Section 807 of PL 104-132," September 2006, 4, http:/ /www.federalreserve.gov/boarddocs/rptcongress/counterfeit/default.htm

13 Board of Governors of the Federal Reserve System. "Z.1 Financial Accounts of the United States, Flow of Funds, Balance Sheets, and Integrated Macroeconomic Accounts, D3 Credit Market Debt Outstanding by Sector," (Washington, DC:The Federal Reserve Board, March 10, 2011), 9, http://www.federalreserve.gov/releases/z1/current/z1.pdf

14 Ben S. Bernake et al., "International Capital Flows and the Returns to Safe Assets in the United States, 2003-2007," Board of Governors of the Federal Reserve System, International Finance Discussion Papers, Number 1014 (Washington, DC: The Federal Reserve Board, February 2011), 8, http://www. federalreserve.gov/pubs/ifdp/2011/1014/ifdp1014.htm 
capacity, build capacity of adversary competitors, and ensure that benefits of association with the United States only flow to indigenous parties who actively share risk, comparable in intensity and duration, with the United States. To neglect the use of some US capabilities in execution of policy is to overuse, rely on, and risk other capabilities.

If the intent of financial warfare is to extend the battlespace into the financial marketplace, then the operational question becomes how to do it? The answer is through macro and micro engagements or strikes across the three principal areas of finance initially targeting the interface between the adversary and the global marketplace.

\section{Capital Formation Strikes}

Inflating or deflating an adversary's currency, or any medium used to store real capital surpluses, is one way to conduct a capital formation strike. A prior requirement for successfully attacking an adversary's capital formation capability is to map how he moves capital and where he aggregates it. This mapping provides, in both broad manner and at a precise point, the adversary's current financial capacity for funding military, paramilitary, or proxy operations, as well as providing significant intelligence on their war-sustainment capability. Feints and spoofing operations can provide insight on how and where an adversary forms capital normally and under duress, as well as uncovering potential targets.

Capital formation strikes encompass the physical, cyber, and informational. Physical strikes can range from general to selective attacks against the telecommunications infrastructure which facilitate financial information flow. For example, interdicting the automated teller machine (ATM) communications system could preclude interbranch and interbank retail capital formation. Capital formation strikes can target and delegitimize the investment sponsor, the investment, or those channels used to evaluate, price, transact, and own it. Strikes directed against a channel itself can be used to deter, retard, or preclude the use of that channel by the investment or its sponsor.

\section{Capital Liquidity Strikes}

Capital market liquidity, for example, is systematic aggregation of capital transactions which are the individual exchange of capital and financial assets between buyers and sellers at volume, rapidly, without loss of value, and among its forms, e.g., commodities, currencies, equity, debt, etc. Deconstructing or reversing the historic arc of capital market liquidity's upward progress is a blueprint for systematically waging financial warfare utilizing capital liquidity strikes. The intent of capital market liquidity strikes, in aggregate, is to target markets and disrupt their drivers of upward efficiencies, speed, volume, and scale, to create a downward spiral of inefficiencies driving markets to a measurable policy objective or collapse. The separation between macro and micro in capital liquidity strikes mirrors that of capital formation. Macro capital liquidity strikes target markets. Micro capital liquidity strikes target individual transactions. 
Micro capital liquidity strikes directed at a specific transaction can include: precluding a buyer from meeting a seller; interfering with or spoofing that transaction's price; preventing title transfer; breaching legitimate market behaviors, or introducing unwarranted regulatory requirements into a specific transaction. Macro capital liquidity strikes can target market capabilities such as transaction speed. Transaction speed is limited by the speed at which information flows through market channels. Reduce channel speed and transaction speed will accordingly reduce. Reduce transaction speed and market throughput will reduce. Likewise, market consistency, transparency and uniformity can be targeted through discrete strikes reducing channel speeds only for specific buyers. When the bid ask spreads are small, discrete channel speed reductions may preclude specified buyers and sellers from transacting within a timeframe available to other market participants. The targeted buyer loses the transaction to other, faster buyers. Eventually, targeted buyers exit, eroding trust in the market's fairness. Trust underlies every market. Erode trust and participants will exit. The competitive margins between markets are typically thin. Affect those margins and disadvantaged participants will exit to seek other, more consistent, transparent, and uniform markets. Additionally, spoofing market participants or deliberately implanting misinformation can attack market transparency, consistency, and the uniform diffusion of data.

\section{Risk Management Strikes}

Risk management is the process of optimizing exposure to financial volatility. ${ }^{15}$ Providers or facilitators of risk management include insurance companies, audit and accounting firms, rating agencies and credit bureaus, and underwriters of collateral, warranties, and hedges. Removal or reduction of an adversary's financial risk management activities can constrain its ability to project power at the granular level (micro) or comprehensively at a systemic level (macro). Eroding or interdicting specific financial risk management mechanisms among adversaries and their commercial enablers can delay or preclude their ability to produce and distribute war materials, project power internationally, support foreign operations or favorably prepare their battlespace through commercial means.

For example, Iran's crude oil sales accounts for 80 percent of Iran's hard currency reserves and for 50 percent of its national budget. ${ }^{16,}$ Iran's continued ability to ship oil, a strategic commodity, to Asia gives it significant economic and diplomatic leverage as well as the financial means to support military operations. However, Iran's ability to ship crude, and for that matter to maintain shipping overall, is dependent upon maritime insurance. Without 3rd party Protection and Indemnity (P\&I) insurance, ships cannot enter most international commercial ports. On February 18, 2011, "Iran's biggest crude oil tanker operator NITC said on Friday its ship insurers had declined to renew policy cover for the coming year due to the impact of tightening sanctions in the European

15 Philippe Jorion, Value at Risk, 3 -15.

16 Kenneth Katzman, Iran Sanctions, Congressional Research Service, June 13, 2013, 53; "Iran Oil Exports Top 844mn Barrels, ” PressTV.com. June 10, 2010, http://previous.presstv.com/ detail.aspx?id=130736\&sectionid=351020102 
Union." ${ }^{17}$ The ability to disaggregate Iran from the global oil market by using a simple risk-management mechanism, in this case P\&I insurance, illustrates the leverage financial warfare offers.

International maritime P\&I insurance requirements illustrate an interesting and under-appreciated aspect of financial risk management strikes. Financial risk management strikes can utilize established international regulatory schemas to attack adversary financial systems, components, or assets. Lacking P\&I insurance, adversary commercial shipping fleets are precluded from many international ports. Insurance and credit problems can also attack the international operations of an adversary's commercial airline industry. Macro risk management strikes can utilize existing safety codes or operating rules to discover fraudulent behaviors or uncover systemic violations of international commerce standards by an adversary or their commercial enablers. Weaponizing and exploiting international commerce schemas can result in delinking entire industries from global trade. For example, increasing ramp inspections or targeting operating audits at adversary commercial enablers could discover violations of safety standards. Many international commercial systems, maritime, aviation, postal, etc. require and enforce safety and behavior standards, particularly where fraudulent behaviors can collapse the system. International commerce rule schemas can legitimately be used to limit or bankrupt an adversary's commercial enablers.

Lastly, on a cautionary note, just as the United States used financial warfare to alter British policy in the Suez, financial warfare may be used against the United States in the future. American vulnerability to financial strikes includes interruptions to highly centralized capital formation chokepoints like the Fedwire Funds Service and the Clearing House Interbank Payment System (CHIPS) which account for more than 858,000 daily interbank transactions totaling $\$ 973$ trillion annually. ${ }^{18}$ Levered derivative US financial products introduce vulnerabilities when risk is opaque and agency problems exist, as illustrated by the role Credit Default Swaps (CDS) played in the 2008 Mortgage Backed Security (MBS) collapse. ${ }^{19}$ The result was bankruptcy and liquidation of major securities as insurance firms induced federal intervention to subsidize failed corporations. Ironically, the whole financial system became less robust rather than more robust. Lastly, deficit fueled (levered) federal spending increases vulnerability to financial strikes across the board by reducing capacity for managing negative outcomes such as errors in forecasting future revenues, constraining current policy due to undercapitalized past actions, and may incent actions such as

17 “UPDATE 2-Sanctions Hit Iran's NITC Ship Insurance Cover,” Reuters, February 18, 2011, http://af.reuters.com/article/energyOilNews/idAFLDE71H1ZC20110218?sp=true

18 Bank for International Settlements, "Payment, Clearing and Settlement Systems in the United States," Committee on Payments Systems and Settlement Redbook. 2012, January 2013, 487-490.

19 Michael Lewis, The Big Short: Inside the Doomsday Machine (New York: W. W. Norton, 2010). The entire book chronicles how the opacity, agency, and asymmetric nature of the CDS market came back to impact both the writers of this form of insurance, chiefly AIG-FP, and the buyers to include Bear Stearns, Lehman Brothers, Morgan Stanley, among others. 
nationalization of pension assets, forced loans to the government, or currency devaluations. ${ }^{20}$

Financial warfare is a new means of power projection that offers the United States significant capabilities in addition to its traditional repertoire. Financial warfare can support US policy objectives by directly attacking an adversary's sovereign financial structures, individual regime elites, or commercial industries and enablers. Financial warfare spoofing operations can assist intelligence collection through isolating, illustrating, and mapping adversary crisis response patterns. Employing financial warfare strikes within an indigenous society's political framework can provide leverage assisting the warfighter by reducing the enemy's capability to fund training, operations, or proxies. Lastly, with significant budget deficits and mounting national debt, the United States is highly susceptible to, and must consider study and defensive application of, financial warfare.

20 Nassim Taleb, Antifragile: Things That Gain from Disorder (New York: Random House, 2012); Alexei Barrionuevo, "Argentina Nationalizes $\$ 30$ Billion in Private Pensions," The New York Times, October 21, 2008, http://www.nytimes.com/2008/10/22/business/worldbusiness/22argentina. html?; Niall Ferguson, The Ascent of Money (New York: Penguin Press, 2008), 69-73. The 15th century Italian city states of Florence and Venice both required wealthy citizens to loan money [Florence: Prestanze, Venice: Prestiti] to their respective governments; Hiroko Tabuchi, "Joining Switzerland, Japan Acts to Ease Currency's Strength," The New York Times, August 4, 2011. In 2010-2011, Brazil, South Korea, Japan, and Switzerland all intervened to preclude appreciation of their currencies in order to maintain exports. 



\section{The Coming Financial Wars}

\author{
Juan C. Zarate \\ (C) 2013 Juan C. Zarate
}

\begin{abstract}
AвSTRACт: Since 9/11, the United States has waged a new brand of financial war against rogue regimes, terrorist groups, and criminal syndicates. By leveraging American global economic predominance, the US has isolated such actors from the financial system. The domain of financial warfare, however, is now no longer the sole province of the US and presents challenges from enemies and competitors.
\end{abstract}

n 8 October 2012, Iranian President Mahmoud Ahmadinejad publicly bemoaned that the Iranian economy was under direct economic assault, with oil sales cut, bank transfers banned, and the value of the Iranian rial and foreign currency reserves plummeting. He admitted plainly, "The enemy has mobilized all its forces to enforce its decision, and so a hidden war is underway, on a very far-reaching global scale.... [W] should realize that this is a kind of war through which the enemy assumes it can defeat the Iranian nation." "He was right. Over the past decade, the United States waged a new brand of financial warfare, unprecedented in its reach and effectiveness. This "hidden war" has often been underestimated or misunderstood, but it is no longer secret and has since become central to America's national security doctrine.

In a series of economic pressure campaigns, the United States financially squeezed and isolated America's principal enemies of this period-al Qaeda, North Korea, Iran, Iraq, and Syria. Far from relying solely on the classic sanctions or trade embargoes of old, these campaigns have consisted of a novel set of financial strategies that harness the international financial and commercial systems to ostracize rogue actors and constrict their funding flows, inflicting real pain.

America's enemies have realized they have been hit with a new breed of financial power. And they have felt the painful effects. Al Qaeda has found it harder, costlier, and riskier to raise and move money around the world and has had to adapt to find new ways to raise capital for its movement. The documents found in Osama bin Laden's compound in Abbottabad, Pakistan, reflect a terrorist leader and movement in search of new sources of money. This development was not new-from 9/11 on, the movement struggled to maintain its core financing. In statement after statement-intended for donors and sometimes only for internal consumption - al Qaeda admitted that it has been choked financially. In a 9 July 2005 letter to Abu Mus'ab al-Zarqawi, leader of al Qaeda in Iraq, Ayman al-Zawahiri, then al Qaeda's number two, asked for money, noting that "many of the lines [of financial assistance] have been cut off."

1 This article is adapted from Juan C. Zarate's Treasury's War: The Unleashing of a New Era of Financial Warfare (New York: PublicAffairs Books, 2013).

2 "Ahmadinejad: Hidden War on Global Scale Waged Against Iran's Oil Sector," Iran Daily Brief, October 8, 2012.

3 Ayman al-Zawahiri to Abu Mus'ab al-Zarqawi, July 9, 2005, Federation of American Scientists, Intelligence Resource Program, http://www.fas.org/irp/news/2005/10/letter_in_english.pdf.
Mr. Juan Zarate is a senior adviser at the Center for Strategic and International Studies (CSIS), the senior national security analyst for CBS News, a visiting lecturer at the Harvard Law School, and a national security and financial integrity consultant. 
The campaign against North Korea had a direct and immediate impact. In the wake of financial pressure unlike any the regime had seen while under international sanctions, North Korea found its bank accounts and illicit financial activity in jeopardy. A North Korean deputy negotiator at the time quietly admitted to a senior White House official, "You finally found a way to hurt us."

The Iranians, too, have suffered the economic effects of a targeted financial assault. On 14 September 2010, former Iranian president Akbar Hashemi Rafsanjani urged the Iranian Assembly of Experts to take seriously the painful sanctions and financial pressures imposed by the United States and the international community. "Throughout the revolution," he said, "we never had so many sanctions [imposed on Iran] and I am calling on you and all officials to take the sanctions seriously." 5 The journalist Moisés Naím opined that the financial pressures on Iran "are biting, the sanctions are very, very powerful. They are the most sophisticated economic and financial sanctions imposed on a country ever."

All of these assaults derive from a blueprint for financial warfare developed years ago by the United States. It is defined by the use of financial tools, pressure, and market forces to leverage the banking sector, private-sector interests, and foreign partners to isolate rogue actors from the international financial and commercial systems and eliminate their funding sources. We successfully formulated and used these strategies during the administration of President George W. Bush, and since the changing of administrations, President Barack Obama and his team continued to rely heavily on this brand of financial warfare. The world faces challenges from rogue states, networks, and actors, but there now exists a well-developed international system to use financial information, power, and suasion to isolate rogues financially. This type of warfare cannot solve all national security issues. However, this private sector-based paradigm gives the United States and its allies the tools and leverage to affect rogue actors and their interests in ways that historically would have been out of reach.

Money creates vulnerabilities. The need for money to survive and operate in the twenty-first century-whether in local economies or globally-creates financial trails that do not lie and dependencies that are hard to hide. In a globalized economy, money flows across borders at a lightning pace and in staggering volumes. With the ease of a phone call or the touch of an app, billions of dollars move every day in myriad ways - via antiseptic wire transfers, the traditional practice of hawala, and satchels full of cash. Money is the common denominator that connects disparate groups and interests — often generating new networks of convenience aligned against the United States. Cutting off funding flows to rogue groups or states restricts their ability to operate and forces them to make choices - not only budget decisions, but also strategic choices. One suicide bombing may cost a terrorist organization less than $\$ 1,000$,

4 Juan Carlos Zarate, "Prologue," in Treasury's War: The Unleashing of a New Era of Financial Warfare (New York: PublicAffairs, 2013).

5 Thomas Erdbrink, "Cleric Calls on Iran to Take U.S.-Led Sanctions Seriously," The Washington Post, September 14, 2010, http://www.washingtonpost.com/wp-dyn/content/article/2010/09/14/ AR2010091403790.html.

6 "Friday News Roundup," The Diane Rehm Show, National Public Radio, October 5, 2012, http:/ / thedianerehmshow.org/audio-player?nid=16725. 
but if that organization cannot pay for all the sophisticated training it would like, cannot adequately maintain its international alliances, and cannot develop all the programs and operations it imagines, then its ultimate impact will be limited.

After September 11, 2001, the United States unleashed a counterterrorist financing campaign that reshaped the very nature of financial warfare. There were three primary themes defining this campaign that shaped the environment and evolution of financial power after 9/11: the expansion of the international anti-money laundering regime; the development of financial tools and intelligence geared specifically to dealing with issues of broad national security; and the growth of strategies based on a new understanding of the centrality of both the international financial system and the private sector to transnational threats and issues pertaining to national security. This environment reshaped the ways in which key actors - namely, the banks - operated in the post-9/11 world.

In this context, governments implemented and expanded global anti-money-laundering regulations and practices based on principles of financial transparency, information sharing, and due diligence. They applied new reporting and information-sharing principles to new sectors of the domestic and international financial community, such as insurance companies, brokers and dealers in precious metals and stones, money-service businesses, and hawaladars (hawala is a trust-based money transfer mechanism).

This approach worked by focusing squarely on the behavior of financial institutions rather than on the classic sanctions framework of the past. In this new approach, the policy decisions of governments are not nearly as persuasive as the risk-based compliance calculus of financial institutions. For banks, wire services, and insurance companies, there are no benefits to facilitating illicit transactions that could bring high regulatory and reputational costs if uncovered. The risk is simply too high. It is the illicit or suspicious behavior of the actors themselves as they try to access the international financial system that triggers their isolation. Such an approach was possible because of the unique international environment after 9/11. Interestingly, under the right conditions, this model created a "virtuous" cycle of self-isolation by suspect financial actors. The more isolated the rogue actors became, the more likely they were to engage in even more evasive and suspicious financial activities to avoid scrutiny, and the more they found themselves excluded from financial networks. The actions of legitimate international financial community participants are based on their own business interests, and when governments appear to be isolating rogue financial actors, the banks will fall into line. Reputation and perceived institutional integrity became prized commodities in the private sector's calculus after $9 / 11$.

These tools and this approach are no longer new. Economic sanctions and financial influence are now the national security tools of choice when neither diplomacy nor military force proves effective or possible. This tool of statecraft has become extremely important in coercing and constraining the behavior of nonstate networks and recalcitrant, rogue regimes, which often appear beyond the reach of classic government power or influence. But rogue actors are already adapting to this kind of financial pressure. It is only a matter of time until US competitors use 
the lessons of the past decade to wage financial battles of their ownespecially against the United States. More worrisome, America's ability to use these powers could diminish as the economic landscape changes. Financial warfare ultimately stems from the ability of the United States to use its financial powers with global effect. This ability, in turn, derives from the centrality and stability of New York as a global financial center, the importance of the dollar as a reserve currency, and the demonstration effects of any steps, regulatory or otherwise, taken by the United States in the broader international system. If the US economy loses its predominance, or the dollar sufficiently weakens, our ability to wage financial warfare could wane. It is vital that policymakers and ordinary Americans understand what is at stake and how this new brand of financial warfare evolved.

\section{Challenges to US Financial Power}

The current economic environment involves three significant trends that undercut America's use of its financial power. The use of new currencies and technologies outside the formal financial system, through the Internet, and with less and less accountability and transparency, undercut the ability to track money flows with traditional means. At the same time, rogue actors are coalescing around a common goal of circumventing and undermining US financial pressure and using financial weapons themselves. Finally, the US dollar-and its predominance-is a target for competitors and those who bemoan the world's reliance on the dollar as the accepted reserve and trading currency as the central element of US financial power.

All of this is happening as the complexity of the global financial system increases, with more financial products and ways of investing and moving money that make tracking and controlling legitimate financial activity increasingly difficult. The current environment-aided by the cloak of anonymity provided by the Internet and the complexity of a global financial system-allows nefarious actors to collude in their activities - quietly and surreptitiously. Iran, for example, is known to use terrorist and militia proxies, such as Hezbollah and Shia militias in Iraq, to extend its influence. Russian intelligence is understood to have close ties to Russian and Eurasian organized crime. China is alleged to use legions of college-aged students as hackers to help drive the cyberespionage attacking Western, Asian, and Indian systems. ${ }^{7}$ The increasing convergence of financial interests between criminal networks and certain nation-states represents an alliance of financial rogues that threatens the international system. States are able to leverage the resources and reach of networked organizations while claiming an arm's-length distance from their nefarious activities. If coordinated, those alliances could target the economic vulnerabilities of the United States.

These actors have new digital tools at their disposal to elude the reach of anti-money-laundering and counterterrorist financing efforts. For example, bitcoin (BTC) is a digital currency transferred through peer-to-peer networks on the Internet. The software, an early implementation of the idea of "crypto-currency," uses cryptography rather

7 Max Fisher, "Someone Found a College Recruitment Notice to Join China's Alleged Military Hacker Team,” The Washington Post, February 20, 2013. 
than central authorities to issue and transfer money. The result is that transactions are cheap, accounts cannot be frozen (unless users keep bitcoins in a separate third-party online wallet service), and there are no prerequisites or arbitrary limits for use. Payments are anonymous, identified only by users' various chosen bitmap addresses. Transactions are irreversible and can be received at any time, even if the user's computer is off. Bitcoin uses opensource software, so anybody can examine the codes of transactions and use the crypto-keys to ensure that no one pays for multiple transactions with the same money. An April 2012 Federal Bureau of Investigation (FBI) report evaluating bitcoin use and exchange rates (currently about $\$ 15$ for one bitcoin) identified bitcoins as an increasingly attractive option for cybercriminals and other illicit groups. The report concluded that criminals will increasingly exploit bitcoins, using malware to steal the digital currency, as well as botnets to generate new currency without preexisting value. The potential for illicit use of bitcoins will only increase as the currency grows in popularity and the exchange rate stabilizes. ${ }^{8}$

Other nontraditional currencies offer criminals and terrorist groups similar opportunities for theft and anonymous movement of money. "Linden" dollars are the virtual currency for the world of Second Life, a digital alternate reality, the first virtual currency to float. They are traded on the LindeX exchange, which is run by the Linden Lab, the creators of Second Life, and can be exchanged for real-world currency. By 2010, user transactions on the LindeX exchange topped $\$ 567$ million in Linden dollars and users cashed Linden dollars into $\$ 55$ million in US dollars."

"Ven" is the digital currency of the social networking community Hub Culture, which operates by invite and includes physical "pavilions" where members meet and collaborate. Members from different countries can exchange a wide array of goods and services in ven at a single global price within the pavilion communities as well as online. Although in 2007 the ven was originally given a fixed exchange rate (10 ven to the dollar), it is now a floating currency and was recently tied to carbon futures, making it one of the world's first "green" currencies. ${ }^{10}$

Bartering has also become a more active way of circumventing the classic financial systems used in local or international trade. Barter exchanges facilitate trades between parties by assigning members "trading credits" equal to the values of goods and services. These credits function similarly to money. Members can exchange goods for credits and use the credits in future transactions. ITEX, the country's largest barter network, which is based in Seattle and boasts more than 24,000 members, charges both a subscription fee ( $\$ 20$ per month) and a transaction fee (6 percent for online trades, 7.5 percent for in-person transactions). Its trading credits are called "ITEX dollars."" The country's five hundred bartering exchanges have become enormously popular in the wake of

8 US Federal Bureau of Investigation, Bitcoin Virtual Currency: Unique Features Present Distinct Challenges for Deterring Illicit Activity, April 24, 2012, http:/ / cryptome.org/2012/05/fbi-bitcoin.pdf.

9 T. Linden, 2009 End of Year Second Life Economy Wrap Up (including Q4 Economy in Detail), January $19,2010$.

10 Eric Savitz, "Currency: Dollars Aren't Enough; Here Comes The Ven (Video)," Forbes, November 11, 2011.

11 "ITEX - Glossary of Terms," accessed December 11, 2013, http://www.itex.com/help/ glossary.asp 
the financial crisis, which both limited access to cash and eroded trust in banks for many people. The International Reciprocal Trade Association estimates the annual US bartering market at around $\$ 12$ billion. ${ }^{12}$ Many participants prefer bartering because it encourages local purchases, links businesses with customers they would not otherwise have found, and increases their ability to sell surplus goods or services.

Many communities now use local currencies and Local Exchange Trading Systems (LETS), community-specific systems based on mutual credit. A Community Exchange System (CES) offers a global alternative to LETS, setting up a much larger currency and trading marketplace that operates in a similar fashion.

\section{Directed Threats and Alliances of Financial Rogues}

Nonstate actors have been quick to recognize the coming age of economic and financial warfare. The documents found in Osama bin Laden's Abbottabad compound spoke of a strategic strike at the economy of the United States by hitting oil tankers and critical energy infrastructure. Indeed, al Qaeda and its associated movements have increasingly focused their rhetoric and strategy on bleeding and bankrupting America. ${ }^{13}$ Part of this strategy involves killing the United States with a thousand cuts by baiting US overreaction and overspending. Al Qaeda in the Arabian Peninsula (AQAP) has labeled this "Operation Hemorrhage."

Another part of this strategy involves hitting key targets and vulnerabilities at a time when the US and global economy is weakened, so as to prolong and exacerbate economic malaise. Energy nodes, transportation chokepoints, and ports around the world provide terrorists and nefarious actors with ample opportunity to shock the interconnected international commercial system. Al Qaeda attempted to do just this in 2006, with the failed attack on the enormous Saudi oil facility at Abqaiq, as well as in 2002, with an attack on the French oil tanker MV Limburg off the coast of Yemen. ${ }^{14}$

International organized crime syndicates have expanded the moneylaundering operations that helped fuel their growth and global financial reach, making them more layered and more varied in their use of investment vehicles. ${ }^{15}$ Such groups not only understand how to profit from the international system but also recognize that certain types of investments and influence can shield their activities and leadership from law enforcement and political pressure. Translated into a more aggressive posture, such groups and potential terrorist allies could see opportunities in controlling certain businesses or wielding influence over particular markets

12 Eric Spitznagel, "Rise of the Barter Economy," BloombergBusinessWeek: Lifestyle, April 26, 2012, http:/ /www.businessweek.com/articles/2012-04-26/rise-of-the-barter-economy

13 "Bin Laden: Goal Is to Bankrupt U.S.," CNN.com, November 1, 2004, http://www.cnn. com/2004/WORLD/meast/11/01/binladen.tape/

142006 attack: Joel Roberts, "Al Qaeda Threatens More Oil Attacks," News, CBS News, February 27, 2006, http://www.cbsnews.com/news/al-qaeda-threatens-more-oil-attacks/; 2002 attack: "Yemen Says Tanker Blast Was Terrorism," BBC, October 16, 2002, sec. Middle East, http:// news.bbc.co.uk $/ 2 / \mathrm{hi} /$ middle_east/2334865.stm.

15 Kristin M. Finklea, "Organized Crime in the United States: Trends and Issues for Congress," Congressional Research Service, January 27, 2010. 
and states, distorting the political frameworks in which they operate through corruption, intimidation, and deepening influence.

As these criminal groups grow more interconnected in ways that transcend national boundaries, such networks are gaining influence in strategically vital markets that could impact the accessibility to and stability of these markets. In addition, the ability of such groups to provide their infrastructure and expertise to others (including terrorists) - whether through access to fraudulent travel documents or access to nuclear material - raises the specter of alliances of convenience and profit aligned dangerously against the United States. ${ }^{16}$

These unholy alliances already exist in some cases. For example, drug trade and human trafficking provided most of the finances for the Mumbai attack. ${ }^{17}$ The US Treasury continues to identify and designate entities in certain jurisdictions - such as Belarus - that are providing weapons and financial facilitation to sanctioned countries — such as Syria.

\section{Attack on the Dollar?}

Attendant to this crisis of fiscal legitimacy are increasing challenges to the primacy of the US dollar. The standing of the dollar allows the United States to shape the global economic and political system and offers it greater influence abroad, greater flexibility at home, and greater insulation from international crises.$^{18}$ For those who would downplay the benefits of dollar dominance, the British experience is instructive. Prior to World War II, the British pound sterling was the primary international currency, thereby allowing Britain to finance military expenditures and manage its wartime debt. Once the sterling was eclipsed by the dollar in the postwar years, Britain was no longer able to finance its war debt, a problem that contributed to its economic decline and exacerbated persistent financial crises during the 1960 s. ${ }^{19}$

The sustainability of the dollar as the leading global reserve currency has been a near constant concern since the 1960s. During this time, foreign dollar reserves began to outgrow US gold reserves, and many international actors began to question the United States' ability to convert dollars to gold at the fixed official rate specified by Bretton Woods. As this confidence declined, speculative attacks against the dollar abounded. The United States eventually abandoned the gold standard, but the dollar has retained its dominance ever since. Thus, anyone decrying the dollar's current strength risks crying wolf.

16 Richard Shultz et al., "The Sources of Instability in the Twenty-First Century," Strategic Studies Quarterly, Summer 2011; Douglas Farah, "Terrorist-Criminal Pipelines and Criminalized States: Emerging Alliances," Prism 2, no. 3 (2011), www.ndu.edu/press/emerging-alliances.html.

17 US Senate Permanent Subcommittee on Investigations, "U.S. Vulnerabilities to Money Laundering, Drugs, and Terrorist Financing: HSBC Case History," July 17, 2012, http://www.gpo. gov/fdsys/pkg/CHRG-112shrg76061/html/CHRG-112shrg76061.htm.

18 Benjamin J. Cohen, The Geography of Money (Ithaca, NY: Cornell University Press, 1998), 128.

19 Hyoung-Kyu Chey, "Theories of International Currencies and the Future of the World Monetary Order,” International Studies Review 14, no. 1 (2012): 51-77; Barry Eichengreen, Globalizing Capital: A History of the International Monetary System, 2nd ed. (Princeton, NJ: Princeton University Press, 1996), 103; Barry Eichengreen, Exorbitant Privilege: The Rise and Fall of the Dollar and the Future of the International Monetary System (Oxford: Oxford University Press, 2011), 40-42; Jonathan Kirshner, "Dollar Primacy and American World Power: What's at Stake?" Review of International Political Economy 15, no. 3 (2008): 418-438. 
Nevertheless, in the wake of the Great Recession, there are convincing signs that we are headed for a restructuring of the international monetary system as faith in the dollar faltered. The reality is that countries are now questioning the wisdom of carrying debt obligations solely in dollars, and they are moving toward baskets of currencies and alternate trading conventions and currencies to reduce their reliance on the dollar. The portion of global reserves in dollars declined from approximately 72 percent in 2000 to 62 percent in 2012 as the rest of the world attempted to decouple from the US economy.

The Chinese have begun to use their own currency, the renminbi, and reserves in certain trading situations and with some partners with more frequency. China recently completed a $\$ 1.08$ billion currency swap deal with Kazakhstan and has similar arrangements with Argentina, Belarus, Hong Kong, Indonesia, Malaysia, South Korea, Ireland, Argentina, and Iceland. China has also reached agreements with Russia and Brazil to gradually eliminate the dollar from bilateral trade. ${ }^{20}$ All five of the BRICS (Brazil, Russia, India, China, and South Africa, all of which have large, rapidly growing economies) have taken significant steps toward trading in their own currencies, diversifying their foreign exchange reserves, and hedging their bets against the growing instability of the dollar and the euro.

Prior to the G8 summit of 2009, China, Russia, and India explicitly called for an end to dollar dominance. On January 7, 2011, the International Monetary Fund (IMF) produced a paper outlining a plan for replacing the dollar with Special Drawing Rights (SDRs)-IMFissued currency defined in terms of the weighted average of the dollar, euro, yen, and pound. The plan would create a liquid bond market for SDRs and thereby elevate the IMF to the de facto role of the world central bank. ${ }^{21}$

This portends a world of multiple reserve currencies, one in which the dollar serves as the primary rudder, steering a steady course to prevent erratic devaluations, but in which the currents are more volatile than they have been for decades. In this scenario, the euro, the British pound, the Swiss franc, and the renminbi would play enhanced roles as regional currencies for Europe and Asia, thereby limiting US influence in these areas.

A more dangerous scenario is an intensification of what James Rickards has termed "Currency War III." According to Rickards, this war began in 2010 and involved competitive devaluations of the yuan, dollar, and euro. These concerns were echoed publicly in 2013 by finance ministries and central banks. It is important to note that the biggest threat is not that yuan devaluation directly damages the US economy. The true threat is systemic. The current China-US monetary relationship is unsustainable and brings the fragility of the entire international monetary system into sharp relief. As Rickards contended, by 2011 both

20 "Brazil-China Bilateral Trade in Real and Yuan Instead of US Dollar," MercoPress, June 30, 2009, http://en.mercopress.com/2009/06/29/brazil-china-bilateral-trade-in-real-and-yuan-instead-ofus-dollar; Toni Vorobyova, "Russia, China to Boost Rouble, Yuan Use in Trade," Reuters, June 17, 2009, www.reuters.com/article/2009/06/17/russia-china-currency-idUSLH72167820090617.

21 Strategy, Policy, and Review Department, Enhancing International Monetary Stability- A Role for the SDR? (International Monetary Fund, January 7, 2011), http://www.imf.org/external/np/pp/ eng/2011/010711.pdf. 
countries were "locked in a trillion-dollar financial embrace, essentially a monetary powder keg that could be detonated by either side if the currency wars spiraled out of control." 22 Economic historian Niall Ferguson has dubbed this presently symbiotic yet ultimately dysfunctional relationship "Chimerica." In order to maintain employment for its massive population, China must keep its exports attractive to American consumers and keep the yuan tied to the dollar. As such, China must continue to buy dollar assets and increase its account surpluses. It is caught in a "dollar trap." China's current exchange-rate policy thus ironically helps to preserve dollar dominance. ${ }^{23}$ Chimerica is, for Ferguson, highly unstable. A sudden deterioration in political relations, perhaps stemming from a clash over natural resources or Taiwan, could trigger a major war and a corresponding collapse of the international financial system. ${ }^{24}$

Currently, China is the most competitive player in the so-called currency wars. Yet all major powers are attempting to influence the relative value of their currencies, a ruthless competition that places the entire global monetary system at risk. The currency war need not devolve into actual war for it to prove disastrous. A small but systemically critical event_ - such as the collapse of the Spanish bond market — could ignite a widespread loss of confidence in paper currencies and a massive transition to hard assets (gold) led by a shrewd and forward-leaning competitor state such as Russia or China. ${ }^{25}$

Even if one doubts the likelihood of such a crisis, China is nonetheless taking steps to internationalize the renminbi and thereby enhance its power relative to the dollar. This is happening in two ways. First, by purchasing sovereign debt of other Asian countries, China pushes up the value of these regional currencies and incentivizes its neighbors to reciprocate by buying Chinese debt in order to devalue their currencies against the yuan. The net result is a greater international role for the renminbi. Second, the Chinese government is finalizing programs that would allow select foreign financial institutions to invest their renminbi deposits in Chinese equity and bond markets. With increased stakes in renminbi-based businesses, these foreign firms will have more

22 James Rickards, Currency Wars: The Making of the Next Global Crisis (New York: Penguin, 2011), 107.

23 Niall Ferguson, The Ascent of Money: A Financial History of the World (New York: Penguin, 2008), 336-337. In Ferguson's view, "Chimerica" was "the underlying cause of the surge in bank lending, bond issuance and new derivative contracts ... the underlying cause of the hedge fund population explosion ... the underlying reason why private equity partnerships were able to borrow money left, right, and center to finance leveraged buyouts . . . the underlying reasons why the US mortgage market was so awash with cash in 2006 that you could get a 100 per cent mortgage with no income, no job or assets." Ferguson has further argued that the United States' loose monetary policy is its own form of currency manipulation, causing the dollar to depreciate approximately 25 percent against the currencies of its major trading partners in recent years ( 9 percent against the renminbi).

24 Ferguson wrote: "One important lesson of history is that major wars can arise even when economic globalization is very far advanced and the hegemonic position of an English-speaking empire seems fairly secure." Ferguson, The Ascent of Money, 339-340.

25 Rickards concluded: "The path of the dollar is unsustainable and therefore the dollar will not be sustained. In time, the dollar will join a crowd of multiple reserve currencies, be subordinated to SDRs, be rejuvenated by gold or descend into chaos with both redemptive and terminal possibilities." Rickards, Currency Wars, 255. 
reasons to promote the renminbi so that they can reap the benefits of renminbi internationalization. ${ }^{26}$

Though the dollar remains superior for now and appears to be the currency of choice amid economic turmoil in Europe, it-along with American financial preeminence-is coming under direct assault.

\section{Conclusion}

In many ways, the United States has taught the world how to use financial power in the twenty-first century. The United States has deliberately leveraged US capital markets, the centrality of the dollar, and American ability to set global standards and mores to drive national security goals. The power of this paradigm is derived from the centrality and stability of New York as a global financial center, the importance of dollar-clearing transactions, and the demonstration effects of any regulatory or other steps taken by the United States or major US financial institutions in the broader international system. Our competitors have learned from our use of power, and our enemies have witnessed our vulnerabilities.

Countries such as Russia and China will continue to challenge the dominance of the US-led international system and the dollar itself. If such attacks succeed, they could weaken the ability of the United States to affect or move private sector decisionmaking in line with national security interests, regardless of what other governments do. The advent of nuclear weapons forced scholars and policymakers to rethink their models and methods for advancing US national security. In a similar way, the coming financial wars will force the United States to adapt amid a new geo-economic order defined by globalization and the speed and ease of communication and transnational commerce. In the age of nuclear competition, the United States drew strength from its scientific and technological advantage; however, it is becoming increasingly clear that America is losing its competitive edge in the era of economic security. This development is particularly troubling in light of the unique advantages it possesses as the vanguard of the international trading and financial system and hub of innovation and collaboration.

The domain of financial warfare will no longer remain the sole province of American power. A wide array of state and nonstate actors may step up to wield economic power and influence in the twenty-first century. Confronting challenges, seizing opportunities, and minimizing systemic vulnerabilities must, therefore, proceed as part of a coordinated effort. The United States must play a new and distinctly financial game of geopolitical competition to ensure its security and to seize emerging opportunities. Just as the mistakes leading to 9/11 were deemed a failure of imagination, the inability of the US government to recognize the changed landscape could be considered a collective failure of comprehension.

26 Chey wrote: "And in fact, a group of prominent international banks, among them HSBC, Standard Chartered, Citigroup, and JPMorgan[,] have recently been holding international roadshows to promote use of the renminbi by their corporate customers for trade deals with China, instead of the dollar. Some of them have moreover offered financial incentives, such as discounted transaction fees, to firms opting to settle their trades in renminbi." Chey, "Theories of International Currencies," 71. See also Robert Cookson, "Banks Back Switch to Renminbi for Trade," Financial Times, August 26, 2010. 
The financial wars are coming. It is time to redesign a national economic security model to prepare for them. If we fail to do so, the United States risks becoming vulnerable and being left behind as other competitors race toward the future. 



\section{Economic Statecraft: China in Africa}

\author{
Douglas W. Winton
}

\begin{abstract}
Aвstract: China's investment in Africa is a deliberate policy choice to secure Beijing's economic and political objectives. Chinese policies may undermine or discourage US efforts to create better governance and improved standards of living in Africa, but these effects are incidental and do not threaten vital American interests. The United States should encourage Beijing's participation in international economic institutions, and thereby facilitate US economic strength and promote African development.
\end{abstract}

n October 2000, China and forty-four African countries established the Forum on China-Africa Cooperation (FOCAC) to "vigorously promote further China-Africa cooperation ... so as to promote the common development of China and Africa." "The subsequent triennial forum ministerial meetings have become elaborate celebrations of deepening China-Africa relations. Concurrently, the Western media heralded China's neo-imperialism, massive investment, and comprehensive strategy to secure exclusive access to Africa's resources. Beijing's "success" in Africa contrasts starkly with Washington's approach to economic statecraft through the African Growth and Opportunity Act and its annual forums. Congress passed this act in 2000 , as China was building the Forum, "to assist the economies of sub-Saharan Africa and to improve economic relations between the United States and the region."2 While many extol the positive effects of the act in improving African governance, its annual forums have been lackluster meetings of bureaucrats, and the Western media highlight that most Africans remain disappointed with the amount of US investment. Similarly, President Obama's weeklong visit to three African nations in July 2013 pales in comparison to the seventeen African nations that $\mathrm{Hu}$ Jintao visited during one ten-month span of his tenure as China's president. This article peers through the public veneer of state visits and ministerial meetings to examine China's influence in Africa through trade, Foreign Direct Investment, and Official Development Assistance. ${ }^{3}$ It argues successful economic statecraft by China does not

1 "Beijing Declaration of the Forum on China-Africa Cooperation," Forum on China-Africa Cooperation, September 25, 2009, http://www.focac.org/eng/ltda/dyjbzjhy/DOC12009/t606796. htm.

2 Vivian C. Jones and Brock R. Williams, U.S. Trade and Investment Relations with sub-Saharan Africa and the African Growth and Opportunity Act (Washington, DC: U.S. Library of Congress, Congressional Research Service, November 14, 2012), 15.

3 Throughout this article, I refer to Africa as if it was a unified entity. In reality, China's economic statecraft on the African continent is varied and recognizes the differences of the fifty-three distinct African nations. However, FOCAC membership and China's African Policy published in January 2006, http://english.peopledaily.com.cn/200601/12/eng20060112_234894.html provides the context for simplifying the analysis with a continent approach. Although US policy often separates North Africa from sub-Saharan Africa (as in the African Growth and Opportunity Act), China's policy does not.
COL Douglas Winton is a candidate for the US Army War College Professor Program. He is pursuing a $\mathrm{PhD}$ in International Relations at Johns Hopkins University. A career field artillery officer, his previous assignments include deployments to Afghanistan and Iraq, battalion command at Ft Sill, OK, and Assistant Professor in Economics at the US Military Academy. 
threaten any vital American interests, and the United States has several possible responses. ${ }^{4}$

Many assess that the increase of China's trade, investment, and developmental assistance from 2000-10 as a means to secure an economic and political advantage in Africa. While Beijing's economic statecraft may undermine US efforts to reform African governance and economics, these effects are incidental; however, Africa would do well to evaluate and balance the long-term costs with the short-term benefits of Chinese aid and investment. Recognizing that China's economic statecraft in Africa does not threaten vital US interests, America should adopt an accommodating posture toward Beijing's involvement there. As part of its overall rebalancing toward the Asia-Pacific, Washington should intensify efforts to increase Beijing's participation in institutions to maintain the global international economic system which facilitates US strength. Simultaneously, the United States should review its approach in Africa to find alternative ways to advance its interests and mitigate the risk to African development inherent in the Chinese approach.

\section{Rationale and Scope}

Beijing's objectives in Africa stem from its "going out" strategy, introduced in its 10th Five Year Plan for 2001-05. This strategy included China's decision to join the World Trade Organization and encouraged businesses to invest abroad. ${ }^{5}$ The resulting economic statecraft in Africa and concomitant creation of FOCAC support four broad objectives: first, access to natural resources which are essential for sustained economic growth; second, new markets for increased domestic production; third, votes in the United Nations and other international forums to diminish criticism of Beijing's human rights record and build support for the People's Republic of China's (PRC's) rise; and fourth, reduced diplomatic recognition of Taiwan. ${ }^{6}$

The PRC's reinvigorated economic statecraft is a boon for Africa. After decades of wrangling with western nations and international

4 David A. Baldwin, Economic Statecraft (Princeton, NJ: Princeton University Press, 1985). Baldwin argues economic statecraft is "economics as an instrument of politics" (3). As described by Secretary of State Hillary Clinton, US economic statecraft includes making economic objectives a part of foreign policy, finding economic solutions for strategic challenges, increasing US exports, and building diplomats' economic capacity. For more see Hillary Clinton, "Delivering on the Promise of Economic Statecraft," lecture, Singapore Management University, Singapore, U.S. Department of State, November 17, 2012, http://www.state.gov/secretary/rm/2012/11/200664. htm. In this article, I refer to China's trade, foreign direct investment, and development aid as economic statecraft since these are generally considered economic tools that China is employing to achieve political and economic objectives.

5 Greg Levesque, “Here's What's Driving China's Investments In Africa,” Business Insider, June 27, 2012, http://www.businessinsider.com/heres-whats-driving-chinas-investments-in-africa-2012-6; Wang Duanyoung, China's Overseas Foreign Direct Investment Risk: 2008-2009 (Johannesburg, South Africa: South African Institute of International Affairs, January 2011), 5,9, 16-17, http://www. saiia.org.za/occasional-papers/china-s-overseas-foreign-direct-investment-risk-2008-2009.html; Christopher M. Dent, "Africa and China: A new kind of development partnership," in China and Africa Development Relations, ed. Christopher M. Dent (New York: Routledge, 2011), 8-12.

6 David E. Brown, "Hidden Dragon, Crouching Lion: How China's Advance in Africa is Underestimated and Africa's Potential Underappreciated," (Carlisle, PA: Strategic Studies Institute, September 17, 2012), 1-2, http://www.strategicstudiesinstitute.army.mil/pubs/display. cfm?pubid=1120; U.S. Congress, Senate Committee on Foreign Relations Subcommittee on African Affairs, Remarks by David H. Shinn, "China's Growing Role in Africa: Implications for U.S. Policy," November 1, 2011, http://www.foreign.senate.gov/imo/media/doc/David_Shinn_Testimony.pdf ; Chris Alden, "China in Africa," Survival 47, no. 3 (Autumn 2005). For decades, the last two political objectives were more important for China than the first two economic objectives. That priority has reversed since 2000 with China focused on its economic objectives first 
organizations about the terms for developmental assistance, African nations can now access financing with "no strings attached" other than to reject Taiwan?. In contrast, for countries to participate in Amerca's African Growth and Opportunity Act, the President must certify they meet a myriad of economic and political conditions. ${ }^{8}$ The simplicity and immediacy of China's economic statecraft, when contrasted with assistance from the United States, entices African leaders to overlook Chinese firms operating without host-nation labor, independent of international environmental standards, and with poor workmanship.?

Although the PRC's economic statecraft in Africa since 2000 is significant in scope and pace of growth, it is not new when viewed historically or massive when compared with economic engagement by the rest of the world. ${ }^{10}$ China's engagement with Africa is easily mischaracterized as new and massive because its relatively opaque systems inhibit complete accounting of previous and current investment and aid. Beijing defines investment and assistance independent of commonly accepted standards, often resulting in poor comparisons with investment and assistance from developed economies. Since the PRC joined the World Trade Organization, however, there is consistent and reliable data to evaluate China's trade with Africa.

\section{China-Africa Trade}

Trade between China and Africa increased from $\$ 10$ billion in 2000 to $\$ 130$ billion in $2010 .^{11}$ In 2000 , trade with A frica was 3.6 percent of the PRC's total trade; by 2010 it had increased to 15.3 percent. ${ }^{12}$ China's portion of Africa's total trade increased from approximately 6 percent in 2005 to 12.5 percent in $2010 .{ }^{13}$ In 2008 , the PRC replaced the United States as Africa's top trading partner with $\$ 100$ billion in total trade. ${ }^{14}$ In 2010, 70 percent of China's imports from Africa was oil and 15 percent was other raw materials (lumber, minerals, food, etc.). ${ }^{15}$ Consistent with these imports being highly concentrated in oil, 70 percent of them come from only four countries: Angola (34 percent), South A frica (20 percent), Sudan (11 percent), and Republic of Congo (8 percent). Likewise,

7 Council on Foreign Relations Independent Task Force Report no. 56, More Than Humanitarianism: A Strategic U.S. Approach toward Africa, (New York: Council on Foreign Relations, 2006), 51, http:// www.cfr.org/africa/more-than-humanitarianism/p9302.

8 AGOA "authorizes the President to designate countries as eligible to receive the benefits of AGOA if they are determined to have established, or are making continual progress toward establishing, the following: market-based economies; the rule of law and political pluralism; elimination of barriers to US trade and investment; protection of intellectual property; efforts to combat corruption; policies to reduce poverty, increasing availability of health care and educational opportunities; protection of human rights and worker rights; and elimination of certain child labor practices." The International Trade Administration, U.S. Department of Commerce, "African Growth and Opportunity Act General Country Eligibility Provisions," http://trade.gov/agoa/eligibility/index. asp

9 Dent, "Africa and China: A new kind of development partnership," 12-16.

10 David H. Shinn and Joshua Eisenman, China and Africa (Philadelphia, PA: University of Pennsylvania Press, 2012), 3; Dent, "Africa and China: A new kind of development partnership," 5.

11 Shinn \& Eisenman, China and Africa, 114-115.

12 United Nations Conference on Trade and Development, Handbook of Statistics 2011 (Geneva, Switzerland: United Nations Publications, 2011), 2-3.

13 Ibid., 90-91.

14 Shinn, "The Impact of China's Growing Influence in Africa," 17. Although the US-Africa trade was greater than China-Africa trade for 2009, China resumed its place as Africa's lead trading partner in 2010 .

15 David H. Shinn, "The Impact of China's Growing Influence in Africa," The European Financial Review (April-May 2011): 11, 17, in Proquest. 
China's exports to Africa are highly concentrated with 55 percent in the continent's five largest economies: South Africa (21 percent), Egypt (12 percent), Nigeria (10 percent), Algeria (7 percent), and Morocco (6 percent). ${ }^{16}$ These five countries are also among the continent's richest and thus lucrative markets for Chinese exports of textiles, machinery, manufactured goods, and communications equipment. ${ }^{17}$ Similar to China, American trade with Africa is concentrated in natural resources from a few countries. ${ }^{18}$

The increase of natural resource exports from Africa to China has contributed to Africa's significant economic growth during the last decade while developed economies have suffered through a financial crisis and sluggish growth. These resources have been important to help the PRC meet its booming demand for energy to sustain increases in manufacturing, economic growth, and poverty reduction. The developing African economies are natural markets for China's relatively inexpensive manufactured goods; however, these compete directly with the nascent African industry and hinder opportunities for development of African manufacturing. ${ }^{19}$ While Africa and China both benefit from the increased trade, Africa's benefits are likely to be short lived without a corresponding investment in infrastructure and structural reforms necessary to move their economy from extractive industries to manufacturing and other higher value-added markets.

This increase in China's trade with Africa does not substantially disadvantage America. Despite recent growth, Africa in 2010 represented only 3 percent of global trade and was not a significant trading partner for the United States. ${ }^{20}$ As developing economies, A frican countries are not natural markets for US products. ${ }^{21}$ Nearly two-thirds of Chinese imports from Africa are oil; however, this represents only 13 percent of A frica's total oil exports and only 3 percent of the PRC's oil requirement. The United States and European Union combined receive 25 percent of Africa's oil exports. ${ }^{22}$ America is projected to be the world's largest oil producer by 2020 and a net exporter of oil by 2035, making China's increased access to Africa's oil of no strategic threat. ${ }^{23}$

\section{China's Investment in Africa}

While trade data is relatively clear, investment data is ambiguous and subject to interpretation because Chinese state-owned enterprises

16 Mary-Françoise Renard, China's Trade and FDI in Africa, Working Paper No. 126, (Tunis, Tunisia: African Development Bank Group, May 2011), 12-14, http://www.afdb.org/fileadmin/ uploads/afdb/Documents/Publications/Working\%20126.pdf .

17 United Nations Conference on Trade and Development, Handbook of Statistics 2011 (New York: United Nations, 2011), 404; David E. Brown, "Hidden Dragon, Crouching Lion," 16.

18 Jones and Williams, U.S. Trade and Investment Relations, 7-12.

19 Ali Zafar, "The Growing Relationship Between China and Sub-Saharan Africa: Macroeconomic,Trade, Investment, and Aid Links," The World Bank Research Observer 22, no. 1 (Spring 2007): 107, in ProQuest.

20 United Nations Conference on Trade and Development, Handbook of Statistics 2011, 10-11.

21 Ibid., xii. Thirty-three African nations are considered heavily indebted and thirty-one are considered least developed. Their economies lack the resources necessary to purchase high-end technological goods. Their markets are focused on subsistence goods, textiles, and basic machinery. These nations will require significant growth before they are able to afford US exports.

22 Shinn, "The Impact of China's Growing Influence in Africa," 17.

23 International Energy Agency, World Energy Outlook 2012 Executive Summary (Paris, France: International Energy Agency, 2012), 1, http://www.iea.org/publications/freepublications/ publication/name,33339,en.html. 
use unique accounting standards which, before 2010, were largely inconsistent with International Financial Reporting Standards. These enterprises often ignore market forces and traditional risk analysis as the government seeks political objectives over sustained profitability. ${ }^{24}$ The PRC establishes the amount and type of investment as a matter of policy; by contrast, western governments set goals and then work with private firms to meet those goals. Chinese investment in Africa is almost analogous to wealthy nations' development assistance, and their commitment of specific investments are not always completed, thus creating further uncertainty as to the true extent of their investment.

One assessment is that China's direct investment in Africa doubled from less than $\$ 1$ billion in 2000 to more than $\$ 2$ billion in 2010, increasing at a rate significantly faster than other investment, making China the single largest investor in Africa. ${ }^{25}$ Many analysts suspect this level underreports the true amount of China's investment. Despite the discrepancy about the precise figures, there are four consistent conclusions about their investment: it has grown substantially over the last decade consistent with its global investment growth; it is a small but significant percentage of China's overall foreign investment ( $\$ 68$ billion in 2010); it is a small portion of global investment in Africa ( $\$ 55$ billion in 2010) leaving traditional investors from the United States, Europe, and Japan in significant positions; and it is highly concentrated in the oil industry and highly concentrated among a few countries. ${ }^{26}$

China's increasing investment in Africa while western investment has remained steady reflects different investment strategies and not African preferences. Investing in Africa provides the PRC with higher returns than the alternative of buying the debt of governments that have forced interest rates to historic lows. Expanding production capacity in Africa also alleviates pressure from excess domestic investment and can facilitate shifting labor-intensive production to Africa as Chinese labor costs rise and their firms seek higher value-added domestic production. Because these firms are accustomed to corruption typical of statecontrolled developing economies, they have a higher risk tolerance for investing in Africa than their western counterparts. China's increased investment in Africa does not indicate US firms are missing opportunities. Rather, America's profit-driven firms have evaluated the risk of investing in Africa and determined the risks are too high to warrant substantial investment.

Many African countries rely on foreign investment to jump start economic growth, expand employment, and mitigate inherent shortages

24 Duanyoung, China's Overseas Foreign Direct Investment Risk: 2008-2009, 16-17.

25 Brown, "Hidden Dragon, Crouching Lion," 18; Vivien Foster et al., Building Bridges: China's Growing Role as Infrastructure Financier for Sub-Sabaran Africa (Washington, DC: The International Bank for Reconstruction and Development / The World Bank, 2009), 3, https://openknowledge. worldbank.org/bitstream/handle/10986/2614/480910PUB0Buil101OFFICIALOUSE0ONLY1. pdf?sequence=1; Shinn, “The Impact of China's Growing Influence in Africa," 17.

26 Simelse Ali and Nida Jafrani, "China's Growing Role in Africa," International Economic Bulletin (Washington, DC: Carnegie Endowment for International Peace, February 9, 2012), http:/m. ceip.org/2012/02/09/china-s-growing-role-in-africa-myths-and-facts/9s2g\&land=en; Foster et al., Building Bridges, 2.Harry G. Broadman, Africa's Silk Road: China and India's New Economic Frontier (Washington, DC: The International Bank for Reconstruction and Development/The World Bank, 2007), 93, 94, http://siteresources.worldbank.org/AFRICAEXT/Resources/Africa_Silk_ Road.pdf; Brown, "Hidden Dragon, Crouching Lion," 19; David Shinn, "China's Investments in Africa," China US Focus, November 1, 2012, http://www.chinausfocus.com/finance-economy/ chinas-investments-in-africa. 
in foreign currency, domestic investment, and tax revenue. Foreign investment can link developing countries to globalized markets, introduce new technology, and improve productivity. ${ }^{27}$ However, China's investment is concentrated in retail and textiles, which add little to African capacity or expertise in industry, processing, or refining capacity which could result in higher value-added manufacturing. ${ }^{28}$ African textiles manufacturing competes with many developing economies for access to saturated markets making this an unlikely industry to achieve substantial growth.

\section{China's Aid for Africa}

Understanding development assistance in Africa is also challenged by ambiguity and imprecise reporting. PRC's banks provide grants, interest-free loans, and concessional loans (considered development assistance by the Organization for Economic Co-operation and Development [OECD]) to Africa without the transparency of western banks. ${ }^{29}$ However, some of China's publically announced loan commitments are at market rates and thus not normally considered aid, adding to the uncertainty of the true scope of assistance. ${ }^{30}$

One estimate of China's developmental aid to Africa is that it has grown from $\$ 600$ million in 2001 to $\$ 2.5$ billion in 2009. ${ }^{31}$ Another study focusing on loans highlights an increase in Chinese lending to Africa from $\$ 800$ million in 2005 to approximately $\$ 1.4$ billion in $2009 .{ }^{32}$ Although there have been many reports of $\$ 1.8$ billion in aid solely in the form of loans, much of this commitment from the Export Import Bank of China was loans at market rates and does not constitute aid in accordance with Organization for Economic Co-operation and Development standards. ${ }^{33}$

China's estimated $\$ 2.5$ billion in aid to Africa is dwarfed by OECD aid of $\$ 29$ billion in $2010 .{ }^{34}$ Among all OECD, the United States gives the most development assistance to Africa with $\$ 7.8$ billion in 2010 . The World Bank's annual aid to Africa of approximately $\$ 4.5$ billion also exceeds China's contribution. Other multinational organizations contribute a combined $\$ 18$ billion annually to Africa. While China's aid grew significantly from 2000-10, OECD aid remained relatively flat as developed economies dealt with growing debt, stagnating financial

27 John C. Anyanwu, Determinants of Foreign Direct Investment Inflows to Africa, 1980-2007, Working Paper No. 136 (Tunis, Tunisia: African Development Bank Group, September 2011), 5, http:/9 www.afdb.org/fileadmin/uploads/afdb/Documents/Publications/WORKING\%20136\%20 Determinants $\% 20$ Of $\% 20$ Foreign $\% 20$ Direct $\% 20$ Investment $\% 20$ Inflows $\% 20$ To $\% 20$ Africa $\% 20$ 1980-2007\%20AS.pdf .

28 Shinn \& Eisenman, China and Africa, 142; Dent, "Africa and China: A new kind of development partnership," 11.

29 Martyn Davies et al., How China Delivers Development Assistance to Africa (Stellenbosch, South Africa: Stellenbosch University--Centre for Chinese Studies, February 2008), v, http://www.ccs.org. za/downloads/DFID_FA_Final.pdf.

30 Shinn \& Eisenman, China and Africa, 148.

31 Deborah Brautigam, The Dragon's Gift (New York: Oxford University Press, 2009), 170.

32 Ali and Jafrani, "China's Growing Role in Africa.

33 Brautigam, The Dragon's Gift,178.

34 Organization for Economic Co-operation and Development (OECD) Development Assistance Committee (DAC), Development Aid at a Glance, Statistic by Region: Africa, 2013 edition, http:/ / www.oecd.org/dac/stats/Africa $\% 20-\% 20$ Development $\% 20$ Aid $\% 20$ at $\% 20$ a $\% 20$ Glance $\% 202013$. pdf; http://www.oecd.org/investment/aidstatistics/42139250.pdf. 
resources, and the economic collapse of $2008 .{ }^{35}$ Much of China's aid to Africa comes as infrastructure projects (railroads, dams, ports, etc.) while western aid is usually intended for improving social conditions (health, education, poverty reduction, etc.) or loan forgiveness. ${ }^{36}$ Thirtyfive African countries have received aid from the PRC to develop infrastructure. As with trade and investment, the infrastructure aid has been concentrated with greater than 70 percent going to four countries: Nigeria, Angola, Sudan, and Ethiopia. ${ }^{37}$

Many of these projects, however, have been criticized for poor workmanship, abusive labor practices, and disregard for environmental considerations. ${ }^{38}$ African leaders whose nations have received Chinese aid have accrued tangible short-term benefits of popular support by demonstrating the ability to deliver infrastructure improvements. However, it remains unclear if this aid will produce lasting economic growth or meaningful improvements in standards of living for their people.

\section{Assessment}

China's comprehensive economic statecraft in Africa is consistent with its goal of a peaceful rise enabled by continued economic growth, improved relations with other countries, and greater inclusion in international organizations. ${ }^{39}$ This increased influence projects an image of a global power with strategic reach and facilitates forming an international coalition to peacefully adjust the international order. China's economic statecraft in Africa not only raises its global standing, it is consistent with the growing need for energy resources and their desire to shift domestic production to higher value-added goods.

China integrates trade policy, investments, and aid to achieve specific domestic economic and international political objectives. Its strategy in Africa helped mitigate the effects of the global recession following the 2008 financial crisis. Through this period, the PRC maintained significant, albeit lower, growth rates; increased trade with Africa is a component of this success. Consistent with this approach, China's chief aid instrument, the Development Bank of China, is a subordinate institution within the Ministry of Commerce. ${ }^{40}$ In contrast, the United States Agency for International Development (USAID) has a loose affiliation with the Department of State and only coordinates with the Department of Commerce which is responsible for facilitating US exports. ${ }^{41}$ The US government's recent emphasis on integrating defense, diplomacy, and

35 Ali and Jafrani, "China's Growing Role in Africa.

36 Shinn \& Eisenman, China and Africa,150-160; Davies et al., How China Delivers Development Assistance to Africa.

37 Foster et al., Building Bridges, 3-4.

38 Nathan William Meyer, "China's Dangerous Game: Resource Investment and the Future of Africa," International Policy Digest, October 9, 2012, http://www.internationalpolicydigest.org/2012/10/09/chinas-dangerous-game-resource-investment-and-the-future-ofafrica/\#comment-4384.

39 Zheng Bijan, "China’s 'Peaceful Rise' to Great-Power Status," Foreign Affairs 84, no. 5. (September/October 2005): 18

40 For a complete description of how China has organized government agencies for economic state craft see Brautigam, The Dragon's Gift, 107-117.

41 For an overview of the US system of Development Assistance see Curt Tarnoff and Marian Leonardo Lawson, Foreign Aid: An Introduction to U.S. Programs and Policy (Washington, DC: U.S. Library of Congress, Congressional Research Service, February 10, 2011). 
development showcases its view that development assistance is primarily intended to achieve national security objectives.

China is reaping political benefits from improved relations with African nations which offer more than fifty votes in the United Nations and other international organizations built on the "one state-one vote" principle. At the December 2012 International Telecommunication Union's (ITU) World Conference in Dubai, China and Russia opposed American and European proposals to maintain the Internet as a global common with mostly unrestricted access. ${ }^{42}$ Of the thirty-five African nations attending, only three (Gambia, Kenya, and Malawi) voted with the United States, resulting in an 89 to 55 defeat for the US and European interest. ${ }^{43}$ As China's economic and military power continue to grow, this increased diplomatic clout will facilitate its attempts to restructure the international order built by the United States and its European allies (who have stagnating population growth and sluggish economies) will also grow. Beijing's relatively small economic investment in Africa has garnered it substantial political support in this endeavor.

Much of the PRC's success in its economic statecraft derives from its view of African nations not as developing countries in need of assistance and reform but rather as equal members of the international community worthy of engagement. It frames this engagement as mutually beneficial for all parties with no expectation for other nations to adjust their domestic standards. Those nations also look to China as a model for development because it has enjoyed historically high growth and raised itself out of the category of least-developed country. While African nations can benefit from infrastructure improvements, debt forgiveness, and increased trade, Beijing's model of a state-controlled economy is unlikely to work for most of these nations as they lack China's size and access to capital. ${ }^{44}$ The nature of Chinese aid and investment, dubious quality of infrastructure projects, accelerated extraction of resources, and undercutting of emerging manufacturing create a long-term risk for African nations that will likely outweigh the current benefits.

Despite China's success, this approach is not an appropriate model for the United States to secure its national interests in Africa. The United States' National Security Strategy lists security, prosperity, values, and international order as its enduring interests. ${ }^{45}$ In June 2012, President Obama signed the US Strategy Toward Sub-Saharan Africa which articulated US interests in the region as ...

ensuring the security of the United States, our citizens, and our allies and partners; promoting democratic states that are economically vibrant and strong partners of the United States on the world stage; expanding opportunities for U.S. trade and investment; preventing conflict and mass

42 L. Gordon Crovitz, "America's First Big Digital Defeat," The Wall Street Journal, December 16, 2012, http://online.wsj.com/article/SB10001424127887323981504578181533577508260.html.

43 Mike Masnick, "Who Signed The ITU WCIT Treaty... And Who Didn't," Techdirt, http:// www.techdirt.com/articles/20121214/14133321389/who-signed-itu-wcit-treaty-who-didnt.shtml.

44 China's development has been accelerated by its ability to access capital through Hong Kong, Macau, and Shanghai. Geography and history have combined to make these cities natural ports and financial hubs. South Africa is the only African nation that enjoys comparable access to capital. The other 53 countries of Africa lack China's attributes calling to question the efficacy of China's model for African development.

45 Barack Obama, National Security Strategy (Washington, DC: The White House, May 2010), 7. 
atrocities; and fostering broad-based, sustainable economic growth and poverty alleviation. ${ }^{46}$

While economic statecraft must contribute to securing these interests, ignoring African governance standards would retard African development, contribute to regional instability, and prolong the continent's pervasive poverty.

However, many African officials resist implementing reforms as preconditions for US development assistance or investment. China's economic statecraft and success in achieving growth with a state-controlled economy has reinforced the hope they can attract foreign capital and investment to spur sustained economic growth without liberalizing their governments. Those benefiting from the investment and infrastructure projects are likely to increase their complaints that America's insistence on governance reforms is an intrusion in their domestic affairs and resist US leadership in international institutions.

\section{Responding}

China's economic statecraft in Africa provides it with economic and diplomatic advantages without threatening any vital US interests. However, the long-term effects are likely to be negative for African countries despite the short-term benefits. Given this complexity, the US response to Beijing's economic statecraft should address three areas. First, the United States should find ways to cooperate with China in Africa, avoiding confrontation or competition. Second, the United States should reinvigorate and strengthen the international economic institutions which undergird the liberal economic order essential for US prosperity. Third, the United States should improve African economic development with its Power Africa and Trade Africa initiatives while sustaining efforts to improve African governance.

As Secretary of State Hillary Clinton noted, "the Asia-Pacific has become a key driver of global politics." ${ }^{47}$ Accordingly, the United States is rebalancing its strategy toward the Asia-Pacific with a recognition in its Defense Strategic Guidance that “China's emergence as a regional power will have the potential to affect the U.S. economy and our security in a variety of ways. Our two countries have . . . an interest in building a cooperative bilateral relationship." 48 Thus, any US reaction toward China's economic statecraft in Africa must consider implications for US-China relations as a first priority. Although some fear China's economic growth and its corresponding increase in military capability, trying to limit this growth is infeasible and inconsistent with US interests. Thus, US policy should accommodate China's peaceful rise while challenging its attempts to change rules and norms of the international system which favor democratic institutions and US strength in global commerce.

America should look for opportunities to cooperate with China in Africa. US-China cooperation there could serve as confidence-building

46 Barack Obama, U.S. Strategy Toward Sub-Saharan Africa (Washington, DC: The White House, June 2012), 1-2.

47 Hillary Clinton, “America’s Pacific Century," Foreign Policy, November 2011, 57.

48 Leon Panetta, Sustaining U.S. Global Leadership: Priorities for 21st Century Defense (Washington, DC: The Department of Defense, January 2012), 2. 
measures as the two nations work through disagreement and potential conflict in the Asia-Pacific region. A natural area for cooperation lies in conflict termination and prevention. China has recently become the leading contributor to UN peacekeeping missions with the United States as the leading funder. The United States should facilitate this trend's continuation.

The United States retains a vital interest in "disrupt[ing], dismantle[ing], and defeat[ing] al Qaeda and its violent extremist affiliates." ${ }^{49}$ In Africa, this means denying safe haven in Somalia, the Maghreb, and the Sahel, and helping threatened countries "build their capacity for responsible governance and security through development and security sector assistance." ${ }^{50}$ Although al Qaeda threatens China less than it does the United States, as Chinese influence and presence grows globally, this threat will likely grow with it. The United States should leverage that growing influence and interest in regional security to help eliminate potential al Qaeda safe havens in Africa.

As the United States seeks areas of cooperation and mutual benefit with China in Africa, it must remain mindful that the PRC views the current international system as one built and maintained by the United States, based on American values, and serving US interests, and thus an inhibitor to its plans for a peaceful rise. Because the United States uses this system to reinforce its values of democracy, transparency, free-markets, and human rights, the system threatens Beijing's view of sovereignty and core interests. China seeks a new international system that reduces the influence of the United States and expands the ideal of state sovereignty. ${ }^{51}$ China is using its economic statecraft in Africa to build support for this world view.

The US response to China's economic statecraft in Africa should focus on strengthening the legitimacy and effectiveness of international institutions which preserve the system of global commerce on which the United States relies for sustained economic grow. For the past decade the PRC has managed the risks associated with greater involvement in the international system and reaped significant economic benefits from doing so. The United States should seek to further anchor the PRC into the current system by inviting it to join the OECD or increasing its votes in the International Monetary Fund. ${ }^{52}$ Simultaneously, the United States should increase the diplomatic pressure for China to allow the free

49 Obama, National Security Strategy, 19.

50 Ibid., 21.

51 Randall L. Schweller and Xiaoyu Pu, "After Unipolarity: China's Visions of International Order in an Era of U.S. Decline," International Security 36, no. 1 (Summer 2011): 53-57.

52 The OECD maintains a working relationship with China since 1995 when the OECD Council agreed to dialogue and cooperation with China. In 2007 the OECD Council adopted a resolution to strengthen cooperation with China, Brazil, India, Indonesia, and South Africa, with enhanced engagement and the potential in the future to lead to membership. "China and the OECD," OECD Better Policies for Better Lives, http://www.oecd.org/china/chinaandtheoecd.htm;. for more about joining the OECD see "OECD enlargement," http://www.oecd.org/general/oecdenlargement. htm. On December 15, 2010, the IMF approved a reform package which includes realigning quota shares (i.e., votes) making China the 3rd largest member country in the IMF. This package requires acceptance by three-fifths of the members having 85 percent of the total voting power. "IMF Quotas," October 1, 2013 http://www.imf.org/external/np/exr/facts/quotas.htm. The United States has not yet accepted these reforms. The Obama Administration has not requested additional funding or authorization from the Congress in order to accept the reforms. Rebecca M. Nelson and Martin A. Weiss, IMF Reforms: Issues for Congress (Washington, DC: U.S. Library of Congress, Congressional Research Service, February 1, 2013), Summary. 
fluctuation of the renminbi (the official currency of the PRC). Success in preserving the system will require discernment to distinguish those changes that can accommodate Chinese desires from those that would erode the system's purpose and effectiveness.

Simultaneously the United States must reinvigorate the credibility and efficacy of the current system which many African nations view as contributing to their stagnation. Many of them have implemented changes to their domestic governments and economies as prerequisites for receiving OECD aid, with the assurance that once implemented the changes would yield benefits; their persistent poverty and inability to compete globally threatens the legitimacy of the current international economic system. America must strengthen and improve its development programs, not because it needs trade with or resources from Africa, but rather because it needs those nations to reap the benefits of global commerce so they have a vested interest in sustaining the system that enables it.

Supporting African development means charting a path to sustainable growth by moving production from solely extractive industries to manufacturing. The Power Africa initiative to "double access to power in sub-Saharan Africa" can be an important tool in achieving this goal. The United States should expand the Trade Africa program to facilitate the development of African manufacturing for exports. ${ }^{53}$ The United States should also push China to modify its investment and developmental assistance approach by hiring more African workers, improving infrastructure quality, and shifting investment from raw material extraction and towards sustainable manufacturing.

\section{Conclusion}

During the last decade, China's economic statecraft in Africa has been a critical component of its going out strategy to sustain economic growth and achieve the power and prestige necessary to influence the international system. This economic statecraft included increases in trade, investment, and developmental assistance as a means of facilitating the growth of its domestic economy and its international power. China and Africa view this new economic statecraft as mutually beneficial despite critiques of Beijing's exploitative approach. China has benefited substantially from its economic statecraft in Africa with increased access to resources, increased exports, and increased support in international organizations.

Because this success does not directly threaten vital interests, the United States should leverage China's new influence to help secure US objectives pertaining to the prevention and termination of conflicts and denying al Qaeda a safe haven on the continent. This focus on core interests can yield more cooperation than competition with China. A

53 "FACT SHEET: Power Africa," The White House, Office of the Press Secretary, June 30, 2013, http://www.whitehouse.gov/the-press-office/2013/06/30/fact-sheet-power-africa; "FACT SHEET: Trade Africa," The White House, Office of the Press Secretary, July 1, 2013, http://www. whitehouse.gov/the-press-office/2013/07/01/fact-sheet-trade-africa. Possible expansions of Trade Africa could include (1) allowing developing nations in Africa to temporarily trade with protectionist measures (i.e., subsidies and tariffs on imports), (2) allowing developing nations in Africa to incrementally adopt global labor and environmental standards; (3) eliminating protectionism of developed economies' (including the United States) agriculture markets; and (4) providing technical assistance to African manufacturing to accelerate its development. 
direct challenge to China's economic statecraft would unnecessarily antagonize China and African nations. Instead, America must reinforce its efforts to preserve the international system by accommodating the PRC as a stakeholder and implementing programs that allow African countries to benefit from its existing norms and values. While the United States continues its efforts to build good governance, reduce poverty, and improve living standards in Africa, it should also encourage China to adjust its engagement in Africa to facilitate long-term African development. Such an approach is the best strategy for responding to Beijing's economic statecraft in Africa in a manner that secures and advances American interests. 


\title{
Repurposing Cyber Command
}

\author{
Frank J. Cilluffo and Joseph R. Clark \\ (C) 2013 Frank J. Cilluffo and Joseph R. Clark.
}

\begin{abstract}
Recent debates about the organizational relationship between Cyber Command and the NSA stress political issues over force employment. This article focuses on the latter, making the case that Cyber Command should be split from the NSA, because nations that marshal and mobilize their cyber power and integrate it into strategy and doctrine will ensure significant national security advantage. Cyber Command provides the best route for developing the tactics, techniques, and procedures necessary for achieving these goals.
\end{abstract}

or twenty years, members of the United States' national security community, including readers of this journal, have debated the potential tactical, operational, and strategic effects of cyber components and capabilities. ${ }^{1}$ Recently, these discussions have become intertwined with arguments about the organizational relationships as well as the Title 10 (traditional military) and Title 50 (intelligence and covert) authorities that exist under the Unified Command Plan. Because of this expanding controversy, there is a growing chorus calling for a split between the National Security Agency (NSA) and US Cyber Command.

These debates are important. Yet they subsume the pivotal issue - how cyber components and capabilities will affect US national security-beneath more transient legal and political issues generated in the wake of Edward Snowden. Furthermore, past and current debates often overlook a basic truth: battlefield outcomes and strategic effects are the product of actual force employment, not theoretical arguments or proving-ground tests.

Cyber Command should be cleaved from NSA, but not for reasons of political expediency. Cyber Command should be split from NSA because the United States needs an organizational arrangement that provides for the development and normalization of Title 10 and Title 50 cyber capabilities, while maintaining a focus on how such will affect the use of military force and US national security. Cyber Command should be split from the NSA because nations that marshal and mobilize their cyber power and integrate it into strategy and doctrine will ensure significant national security advantage, and Cyber Command currently provides the best route for achieving such. ${ }^{2}$

Cyber Command should be removed from under US Strategic Command and established as a unified combatant command. That action

1 The debate began with John Arquilla and David Ronfeldt, "Cyberwar is Coming!" Comparative Strategy 12, no. 2 (Spring 1993): 141-165. The phrase "cyber components and capabilities" is used to denote computer network attacks (CNA), computer network exploits (CNE), and computer network operations $(\mathrm{CNO})$, as well as future developments both within and beyond these categories.

2 Frank J. Cilluffo and J. Richard Knop, "Getting Serious About Cyberwarfare," The Journal of International Security Affairs (New York: Jewish Institute for National Security Affairs, 2009). 
represents the most effective means for developing and maturing the tactics, techniques, and procedures that will allow US cyber components and capabilities to be employed for military purposes and to generate strategic effects. Currently, there are two primary reasons why the establishment of a unified combatant command presents a better solution than tasking existing branch and service structures. First, speed is of the essence. Tasking an existing branch or service, or even establishing a new service, would open up organizational and bureaucratic rivalries likely to slow (if not cripple) the development of cyber components and capabilities. Second, in the near term, Title 10 and Title 50 concerns, vagueness in the cyber rules of engagement, concerns about political blowback, and fears that US cyber weapons could be reverse engineered and used against the United States, all highlight the importance of an organizational solution that synchronizes and deconflicts activities across the whole of government. In short, the United States needs a combatant command that can do two things: (1) craft the tactical, operational, and strategic cyber capabilities US national security will need in the decades to come; and, (2) oversee their application, integration, and execution. Cyber Command is the best choice and now is the time to act.

\section{Operationalizing Cyber}

When Cyber Command was established in 2009, it made sense that it be stood up as a sub-unified command under Strategic Command. Until recently the line between computer network attacks and computer network exploits was chiefly one of intent (i.e., if you had the ability to exploit, you had the ability to attack). The use of cyber was largely constrained to information collection and intelligence. Kinetic effects and battlefield uses were essentially theoretical, not practical. In addition, because of the scarcity of manpower and materials, it made sense that Cyber Command and the NSA be joined by the dual-hatting of their commander, General Keith Alexander. This allowed the two organizations to pool resources and avoid redundancy.

Today, the situation is different. The kinetic potential of cyber components and capabilities have been demonstrated, attempts to employ them for strategic effect have been undertaken. The use of cyber in support of operational or strategic objectives is becoming increasingly common. Three examples in a growing universe of cases illustrate this point. The 2009 Stuxnet attack against Iran's nuclear-fuel centrifuges temporarily halted Tehran's enrichment program. The 2011 distributed denial of service attacks against government and media websites slowed the counterconcentration of Georgian forces in response to Russia's military invasion. ${ }^{3}$ The 2012 distributed denial of service attacks against American banks, launched in retaliation for the US-led sanctions against Iran, exposed a weak point that potentially could be used to coerce the US government. ${ }^{4}$

These cases suggest future conflicts will contain cyber elements at both the operational and strategic levels. Such is the new reality. Regardless of asymmetries in other capabilities, cyber components and capabilities

3 David Hollis, “Cyberwar Case Study: Georgia 2008," Small Wars Journal, January 6, 2011, http://smallwarsjournal.com/jrnl/art/cyberwar-case-study-georgia-2008.

4 Richard Davies, "Iran Suspected in Bank Site Hacking," ABC News, January 9, 2013, http:// abcnews.go.com/blogs/business/2013/01/iran-suspected-in-bank-site-hacking/ 
are now part of the battlefield and the strategic environment writ large. At the same time, there are important differences between the use of tactical and operational level cyber in conjunction with activities on the physical domains, and strategic activities occurring solely within the cyber domain itself. The result is a growing divergence between the missions of the NSA and Cyber Command - as well as a growing divergence in the skills and capabilities each needs to fulfill its respective mission.

The increasing use of cyber at the operational and strategic levels creates impetus for all military forces, from those of powerful nationstates to those of weak insurgent movements, to acquire cybercomponents and capabilities. Cyber is not an instrument of the weak or the strong, it is an instrument-period. It is becoming conventional wisdom that "the ability to use cyberspace to create advantages and influence events in all other operational environments and across the instruments of power" will ensure significant advantage. ${ }^{5}$ America's adversaries are preparing for the operationalization of this conventional wisdom; the United States must do so as well.

Still, the acquisition of new technologies is not enough. Stephen Biddle argues that technology magnifies the effects of force employment. ${ }^{6}$ Technology makes capable forces more capable. If integrated properly, technology enhances how military units execute or react to actions born out of the principles of war: mass, maneuver, surprise, security, simplicity, objective, offensive, economy of force, and unity of command. Biddle warns, however, that technology is not a substitute for good force employment. It will not make a "bad" force better. ${ }^{7}$ This suggests that if cyber components and capabilities are to have actual strategic effect, careful thought must be given to their application, integration, and execution. What is needed is an entity that can:

- Think through these issues in regard to computer network attacks and the defense of Department of Defense (DOD) systems.

- Mature the cyber components themselves as well as the tactics, techniques, and procedures for their use.

- Deconflict efforts across the whole of the US government.

Cyber Command represents the best entity for accomplishing all of the above.

To allow Cyber Command to fulfill these roles, the Unified Command Plan should be modified. Cyber Command should be cleaved from the NSA, taken out from under Strategic Command, and established as a functional combatant command. Cyber Command, like US Special Operations Command, should receive direct Congressional funding as a major force program, with the services free to make additional investments (as they do with Special Operations Command). ${ }^{8}$ Unlike Special Operations Command, Cyber Command should have

5 Franklin Framer, Stuart Starr, and Larry Wentz, Cyberpower and National Security (Washington, DC: National Defense University, 2009); Cilluffo and Knop, "Getting Serious About Cyberwarfare."

6 Stephen Biddle, Military Power: Explaining Victory and Defeat in Modern Battle (Princeton, NJ: Princeton University Press, 2004), 146.

7 Ibid., 164.

8 Eric Olson, "The Future of Special Operations: Proposed Changes in the Unified Command Plan," Comments at the Global Security Forum (Washington, DC: Center for Strategic and International Studies, 2012). 
operational authority and the ability to initiate a request that forces be attached to a geographic combatant command in response to identified threats. In short, it is time to let Cyber Command come into its own.

At present Cyber Command exists, much as Special Operations Command did in the wake of the $9 / 11$ attacks, in the organizational shadows unable to contribute its full potential to the security of the United States. Establishing Cyber Command as a combatant command would allow it to leverage its existing capabilities and organizational relationships to develop US cyber capabilities through the fulfillment of two missions. One mission would be to act as an incubator for operational cyber capabilities. The other mission would be to act as the designated operator for offensive actions within the cyber domain itself.

In its incubator role, Cyber Command should act as facilitator for the development of cyber components and capabilities to enhance modern force employment and integrate cyber components and capabilities into the combined arms framework. In this role, Cyber Command should work with the Defense Advanced Research Projects Agency (DARPA), the services' various combat training directorates, academic programs, and other private and public sector entities. Cyber Command would, as the other combatant commands do, task the NSA for information and capabilities in support of its primary mission. The goal would be to develop, demonstrate, and disseminate capabilities for cyber enhanced combat operations on the terrain of the physical domains. Cyber Command should act as a client and partner for activities such as DARPA's Project $\mathrm{X}$, which seeks to map enemy networks, develop mission scripts for the use of cyberweapons, and develop techniques for assessing battle damage to cyber components and capabilities. ${ }^{9}$ Cyber Command should act as a repository for lessons learned about the operational employment of cyber and the lead for activities regarding how cyber components and capabilities should be folded into the Joint Munitions Impact Modeling System (JMIMs). Cyber Command would then be able to provide war planners with more robust tools for understanding the likely effects of cyber attacks, yielding as much confidence about the effects of computer network attacks, as about the use of traditional munitions. Its incubator role would allow Cyber Command to refine tactics, techniques, and procedures based on actual battlefield experiences-including those from the use of cyber in Afghanistan-so that cyber is operationalized on the basis of combat experience rather than just theoretical or proving-ground tests. ${ }^{10}$ In short, Cyber Command should be charged with finding out how US forces could employ cyber to better execute the principles of war within mission, enemy, terrain, troops, time, and civilian (METT-TC) constraints.

In its operational role, Cyber Command should remain the entity for operations that occur within the networks and systems that make up cyberspace. In fact, Cyber Command ought be designated at the combatant command for the cyber domain. It should own all offensive or defensive cyberborne operations not related to intelligence collection.

9 Tom Gjelten, “First Strike: US Cyber Warriors Seize the Offensive,” World Affairs (January/February 2013), http://www.worldaffairsjournal.org/article/first-strike-us-cyber-warriors-seize-offensive.

10 Sterling C. Beard, "Marine officer says US using cyberwarfare in Afghanistan," The Hill (Washington, DC: Capitol Hill Publishing Corporation, August 24, 2012), http://thehill.com/ blogs/defcon-hill/marine-corps/245421-marine-officer-says-us-using-cyberwarfare-in-afghanistan. 
Making one entity responsible for the use of components and capabilities in the cyber domain will protect American assets. It will ensure their cautious use, reducing opportunities adversaries might have to copy and reverse engineer them. ${ }^{11}$ Cyber Command should continue to field cyberwarfare teams, like those General Alexander discussed before the Senate Armed Services Committee in March 2013. ${ }^{12}$ Cyber Command, through a sub-unified command within it, should play a role analogous to the one Joint Special Operations Command (JSOC) plays in regard to counterterrorism. Once the intelligence community identifies a target and the national command authority makes the decision to act, Cyber Command should "pull the trigger." To ensure accountability and deconflict efforts across the whole of the US government, this process should occur through a Title 10 and Title 50 synchronization process similar to that of JSOC. Cyber Command should have responsibility for this process, and then responsibility for implementing computer network attacks. Cyber Command should continue to be responsible for synchronizing and coordinating the actions of the service components: US Army Cyber Command, the US 10th Fleet, the 24th Air Force, US Marine Corps Force Cyber Command, and US Coast Guard Cyber Command. ${ }^{13}$ This operational role, in addition to being vital in itself, would support Cyber Command's incubator mission through the constant development of new cyber components, capabilities, and skill sets.

Making the above happen requires a greater division of labor between the NSA and Cyber Command. The use of cyber as an intelligence asset should be separated from the use of cyber as a military asset. The NSA should continue to be responsible for and have authority to execute cyberborne operations related to intelligence collection. More specifically, the NSA should continue to be responsible for capturing information from potential or existent US adversaries via computer networks and operations; and support efforts to protect American networks from similar attempts on the part of foreign governments, criminal organizations, and others. In essence, this separation would make Cyber Command responsible for Strategic Initiative 1 and the NSA for Strategic Initiative 2, with each entity taking responsibility

11 Frank J. Cilluffo and Sharon L. Cardash, "Cyber Domain Conflict in the 21st Century," The Whitehead Journal of Diplomacy and International Relations 14, no. 1 (January 2013).

12 Richard Lardner, "US forming cyber teams to take offensive," The Boston Globe, March 13, 2013. http://www.bostonglobe.com/news/nation/2013/03/12/pentagon-forming-cyber-teamsprevent-attacks/UcUxkq95wj2FCXTQ3LJsvM/story.html.

13 United States Department of Defense, Department of Defense Strategy for Operating in Cyberspace (Arlington, VA: United States Department of Defense), 5, http://www.defense.gov/news/ d20110714cyber.pdf. 
for the remaining three as outlined in the July 2011 "Department of Defense Strategy for Operating in Cyberspace":

- Strategic Initiative 1. "Treat cyberspace as an operational domain to organize, train, and equip so that [DOD] can take full advantage of cyberspace's potential."

- Strategic Initiative 2. "Employ new defense operating concepts to protect [DOD] networks and systems."

- Strategic Initiative 3. "Partner with other [US] government departments and agencies and the private sector to enable a whole-of-government cybersecurity strategy."

- Strategic Initiative 4. "Build robust relationships with [US] allies and international partners to strengthen collective cybersecurity."

- Strategic Initiative 5. "Leverage the nation's ingenuity through an exceptional cyber workforce and rapid technological innovation."

This division would allow each entity to develop and refine the particular cyber techniques and skills most likely to bring about success within their respective realms.

The need to separate Cyber Command from NSA, and to establish it as a functional combatant command goes beyond force employment or operations within the cyber domain onto itself. Cleaving Cyber Command from NSA also addresses the need to balance (and rebalance) Title 10 and Title 50 authorities. The convergence of traditional military missions with intelligence and covert action is not new. General Edward Meyer, Army Chief of Staff from 1979 to 1983, recognized the need for such. General Meyer argued that America's "adversaries were affecting us below the threshold of war," necessitating the development of new capabilities. The result was the birth of special operations as a community that could blend combat capabilities, intelligence, and covert action. In response to world events of the last three decades - including the Iranian hostage crisis, the rise of Hezbollah and the bombing of the Marine barracks in Beirut, and later al Qaeda and 9/11-this convergence of military, intelligence, and covert activities has continued. Yet, in some areas, even when operationally necessary, convergence has clouded authorities. It has made it unclear as to which parts of the government are responsible and accountable for various actions. Given how they permeate modern life, cyber components and capabilities raise new issues. Cyber adds concerns about privacy to those about force employment and intelligence. Separating Cyber Command from NSA would support the synchronization of Title 10 and Title 50, where necessary, and alleviate privacy concerns by clarifying the authorities for conducting various cyber operations within specific contexts. ${ }^{14}$

Three additional issues must be resolved to establish Cyber Command as a functional combatant command charged with maturing the US cyber capabilities and executing operations within the cyber domain.

14 Robert Chesney, "Military-Intelligence Convergence and the Law of Title 10/Title 50 Debate." Public Law and Legal Theory Research Paper Series Number 212, (Austin, TX: The University of Texas School of Law, October 17, 2011), http://ssrn.com/abstract=1945392; Andru Wall, "Demystifying the Title 10-Title 50 Debate: Distinguishing Military Operations, Intelligence Activities \& Covert Action." Harvard National Security Journal3, no. 1 (Cambridge, MA: Harvard University, 2011), http:// harvardnsj.org/wp-content/uploads/2012/01/Vol.-3_Wall1.pdf. 
First, Cyber Command must have budgetary independence to ensure its needs are not squeezed out by bureaucratic competition with the service components, other combatant commands, or weapons systems. For this reason, Cyber Command should receive direct funding from Congress as a major force program. The other services should be free to make investments in Cyber Command, but the command must have a budget insulated from the concerns or needs of the services themselves, the other combatant commands, or the DOD itself. Second, unlike Special Operations Command, Cyber Command must be granted the ability to initiate a request that specific cyber components and capabilities be attached to geographic combatant commands in response to identified threats. Because of the unique nature of Cyber Command's expertise, especially in the near term, the command is likely to possess greater understanding of the cyber threats and opportunities faced by other combatant commands. The fulfillment of such requests should require input from the receiving command before being decided by the national command authority. Third, Congress and the executive branch must make significant investments in the personnel needs of both NSA and Cyber Command. The size of the cyber work force should be increased, and training of individuals tailored to the missions and requirements of their respective command. It is imperative that Congress and the executive branch supply the resources necessary to accomplish this. The United States must avoid a situation in which Cyber Command and the NSA are left operationally anemic by a lack of qualified personnel and a need to compete with one another for the highly skilled individuals each needs to fulfill their respective missions.

Today, there are three broad reasons to undertake the above proposal. First, it would facilitate the integration of cyber components and capabilities into the combined arms framework, and provide an effective mechanism for the crafting of cyber tactics, techniques, and procedures. Second, it represents the most efficient, and most likely, path for achieving the strategic initiatives outlined in the 2011 Department of Defense Strategy for Operating in Cyberspace. ${ }^{15}$ Third, it keeps cybersecurity discussions, policy, and practice focused on the fact that the central issues - even in regard to the potential for cyberwarfare-are inherently about grand strategy and human conflict, not technical capability.

To be clear, the establishment of Cyber Command as a functional combatant command does not represent a panacea. It leaves unaddressed important issues regarding the security of the US private sector cyber assets and resources, including jurisdictional issues among the NSA, the Department of Homeland Security, and the Federal Bureau of Investigation. It also leaves unaddressed important issues about the rights and responsibilities of the US private sector regarding the ability to engage in the active defense of their computer networks and systems from the efforts of organized crime, foreign attacks, and state-sponsored espionage. Still, doing so represents the best means (at present) for developing and normalizing Title 10 and Title 50 cyber capabilities for offensive action and in defense of DOD computer networks and systems. It also represents the logical mechanism for attempting to 
achieve the Presidential Policy Directive-20 goal of using cyber to dissuade, deter, or compel US adversaries. ${ }^{16}$

\section{Conclusion}

It is critically important that the United States act now to integrate cyber fully into operational level force employment. Evidence suggests America's adversaries are doing just that. Given America's greater reliance on cyber, and thus greater vulnerability, US national security necessitates it maintain a dominant position in regard to cyber. Dominance comes through application, integration, and execution. At this point, the United States needs to designate one entity to take lead in the development and maturing of the tactics, techniques, and procedures that will allow cyber components and capabilities to be employed for military purposes, establish dominance, and generate strategic effects. For these reasons, it is time to establish Cyber Command as a functional combatant command.

\section{Frank J. Cilluffo}

Mr. Cilluffo is an Associate Vice President at George Washington University where he directs university-wide Cybersecurity Initiative and the Homeland Security Policy Institute. He previously served as Special Assistant to President George W. Bush for Homeland Security.

\section{Joseph R. Clark}

Dr. Clark is a policy analyst at The George Washington University's Homeland Security Policy Institute and Adjunct Professor at Virginia Commonwealth University.

16 Robert O’Harrow and Barton Gellman, "Secret cyber directive calls for ability to attack without warning," The Washington Post, June 7, 2013, http://articles.washingtonpost.com/2013-06-07/ world/39817439_1_cyber-tools-president-obama-directive. 
A War Examined:

\section{Operation Iraqi Freedom, 2003}

\author{
A Discussion With Kevin Benson, COL (USA Retired) \\ (C) 2013 Kevin Benson
}

\section{Describe your background and your key duties and responsibili- ties in OIF.}

Benson: I started my Army career as an Armor/Cavalry officer and served in tank battalions, divisional cavalry squadrons and a cavalry regiment. I also served as a planner at the corps and army level. My key duty and responsibility during the opening stage of Operation Iraqi Freedom was serving as the C/J-5 of the Combined Forces Land Component Command (CFLCC). As such, I coordinated the development of the CFLCC major operations plan COBRA II, our initial plan for the invasion, and ECLIPSE II, our sequel plan for post-hostilities operations. Having thought about war for a long time, and reflecting on my experience at war, I believe professionals must recognize two key points: (1) before taking the decision to use force we have to advance the discussion of military requirements AND policy guidance so all parties understand what we are doing, and (2) we military professionals must ALWAYS bear in mind that political and policy conditions are going to change in the duration of a campaign. We must keep this in mind because policy will change and war, being an instrument of policy, must match the objectives of policy. The political object is the real motive for war and thus will determine the amount of effort needed to attain the objective.

\section{What kind of policy guidance did you receive, and what were the main sources of your guidance?}

Benson: I worked for two CFLCC commanding generals: LTG P. T. Mikolashek and LTG David McKiernan. LTG Mikolashek's guidance and mine flowed from the Office of the Secretary of Defense through US Central Command (CENTCOM) and GEN Franks. Mikolashek initially offered the base war plan for the invasion of Iraq, the so-called standing start plan. It was immediately pooh-poohed as "old think" by Secretary Rumsfeld. This plan was first developed in the aftermath of the first Gulf War envisioning a long build-up of forces followed by the invasion. Mikolashek was leaving command as we were developing the rudiments of the so-called "running start" plan. This plan envisioned starting the invasion with a minimal force and then deploying forces as needed. The next plan was termed the "hybrid" plan. It reflected an effort by all ground component officers, Army and Marine, to increase forces on the ground before the start of the war and continue the deployment/employment cycle of the remainder of the apportioned forces.

The policy objectives at the start of the Iraq war were plainly stated in the Central Command campaign plan, 1003V. They were: a stable Iraq, with its territorial integrity intact; a broad-based government that renounces weapons of mass destruction (WMD) development and use, and no longer supports terrorism or threatens its neighbors; and success
COL Kevin Benson, USA Retired, completed his military career as Director of the School of Advanced Military Studies at Fort Leavenworth, KS (2003-07). He was the C/J 5 (Director of Plans) for Third US Army and the CFLCC at the start of Operation Iraqi Freedom, from July 2002 to July 2003. In October, he assisted in planning the mission transfer in Iraq. 
in Iraq leveraged to convince or compel other countries to cease support to terrorists and to deny them access to WMD.

The military objectives were to: destabilize, isolate, and overthrow the Iraqi regime and provide support to a new, broad-based government; destroy Iraqi WMD capability and infrastructure; protect allies and supporters from Iraqi threats and attacks; destroy terrorist networks in Iraq; gather intelligence on global terrorism; detain terrorists and war criminals and free individuals unjustly detained under the Iraqi regime; and support international efforts to set conditions for long-term stability in Iraq and the region. We used these objectives to develop our campaign and major operations plans. My duties during the development and execution of our plans encompassed more than directing, planning, and reviewing written products.

LTG McKiernan took command of CFLCC in September of 2002; however, our policy and military guidance remained unchanged. What was in flux, almost until D-Day, was the number of forces we would have to execute the plan.

\section{How often did the guidance change, and how did you adjust your battle rhythm to accommodate such changes?}

Benson: The best way to answer this is to say the ends of the policy/ strategy did not change. We faced a constant tension regarding the means in terms of how many troops we would be allowed for execution. For example, in February of 2003, right around the time GEN Shinseki offered his answer regarding the number of troops required for an occupation of Iraq, we began to receive inquiries from staff officers within the Office of the Secretary of Defense concerning "off-ramps." The off-ramps were specifically directed at not deploying Army divisions to the theater. We had not yet started the campaign and we were engaged in justifying the necessity of follow-on forces.

As another part of my duties during execution of $1003 \mathrm{~V}$ and our plan, COBRA II, I participated in the daily secure video-teleconferences (SVTC) with the Secretary of Defense and his senior staff. These sessions produced lots of sound and occasional fury as different people spoke, usually after Mr. Rumsfeld left the room. For example, on 24 March 2003, after an explanation by LTG John Abizaid, of how the coalition would deal with Ba'ath party members, Douglas Feith stated that "de-Baathification" was the policy of the US government. He actually thumped on the table to emphasize his point. He went on to say that mere party membership was not an automatic disqualifier for future work in the new Iraqi government. This was counter to my understanding of the guidance given during planning by Abizaid to the people on the SVTC. During the conference and immediately afterwards, I asked for clarification of this (to me) just announced "policy." I never got a response. Policy confusion did not end with this one secure video-teleconference. ${ }^{1}$

1 This paragraph is based on the personal journal I kept while serving as the C/J 5 of the Combined Forces Land Component Command, entry dated 24 March 2002, and hereafter cited as Journal with the associated date. 


\section{How did you decide between conflicting policy aims?}

Benson: I do not wish to appear taking on too much for myself. I was charged with the continued refinement of my commanding general's plan while he was engaged with the oversight of execution. As best as I can recall, the circumstances of the battlefield dictated which way to go regarding conflicting policy aims. To return to "de-Baathification," since no one either amplified or clarified Feith's "policy" announcement, we continued with our work. In mid-May 2003, we received a visit from Mr. Walt Slocombe, the Coalition Provisional Authority's senior representative in the post-Saddam Iraqi Ministry of Defense. On 18 May 2003, we presented a briefing to Slocombe on the proposal for the establishment of what we were calling the New Iraqi Corps (NIC). LTG McKiernan's guidance to me and the planners, based on what he knew Slocombe was bringing with him from Washington, was to bear in mind two what he termed "principles": (1) nobody above the rank of LTC will be allowed into NIC, and (2) no reestablishment of any Ministry of Defense organization in the near term. Reestablishing the Iraqi army would require a grass-roots, bottom-up approach. Slocombe would listen to McKiernan's input regarding the use of former Iraqi army general officers and determine if they could serve as advisors in the process. I was to consider the effect these two principles would have on recruitment, additional anti-coalition effects such as continued armed opposition by former regime loyalists, and finding leadership for the NIC. The outcome of the briefing was not quite what we anticipated. ${ }^{2}$

Slocombe listened to our presentation very closely. Near the end, I asked if we were still acting in accord with policy since we had based our planning on the assumption that we could recall the regular Iraqi army. I asked this twice during the presentation. Slocombe's answer was, "Thanks for the briefing Colonel." Thus, when Slocombe left, we were still unsure of where our operations to reestablish the Iraqi Army stood vis-à-vis US policy. Later, Ambassador Bremer, acting essentially as proconsul in Iraq, disbanded the Iraqi army and prohibited anyone who held Ba'ath party membership from joining the new Iraqi government. This made execution of our existing plan problematic, to say the least.

\section{How well did your professional military education prepare you for your role as a planner?}

Benson: On the surface one would expect that, since I was a Command and General Staff College (CGSC) and School of Advanced Military Studies (SAMS) graduate, a graduate of a US Army War College Fellowship at the Massachusetts Institute of Technology (MIT) Security Studies Program, that my education, as well as my post SAMS experience as a planner, was the best preparation possible to serve as the chief planner for a land component. I certainly did not want to "take counsel of my fears." On the other hand, this was my very first, and only, war experience. I was conscious of that as well. On the whole, my formal professional military education and my personal continuing studies prepared me for the start of the war planning. I adapted afterward and that, too, was aided by the totality of my preparation.

2 Journal, entries dated 18 and 25 May 2002. 


\section{Were the types of forces you had on hand sufficient and the right kind?}

Benson: The entire apportioned force was the correct force to serve as an "instrument of policy." The joint combined arms team was appropriate to execute the invasion successfully and, I believe, conclude the campaign through phase IV. We had an entire Marine Expeditionary Force and a US Army Corps of six divisions and two cavalry regiments as well as appropriate combat support and combat service support forces. This was the apportioned force. It is a moot point, of course, but we will never know if committing the entire apportioned force for the expected 125 days of our so-called phase III followed by six months to a year of phase IV would have ended with a different result.

\section{What words of advice would you offer to other war planners?}

Benson: While professional soldiers study war, in the 21st century they must also study policymaking. Soldiers and policymakers cannot afford the risk of talking past each other as happened during the Iraq war. This is more likely now than in our history because policy elites and professional soldiers seem increasingly to come from widely disparate backgrounds. ${ }^{3}$ Professional soldiers and professional policymakers should accept that they approach the problems of strategy from dramatically different perspectives. This phenomenon is clearly not associated with one or another party. Military professionals must understand the domestic and foreign pressures on the development of policy. Soldiers, marines, sailors, and airmen should take the first and longest step to close the gap and reconcile perspectives. To quote Clausewitz, "To bring a war, or one of its campaigns to a successful close requires a thorough grasp of national policy. On that level strategy and policy coalesce."”

The end result of spending a year at CGSC, SAMS, and the War College should be a broader view of the circumstances of war and a shared understanding of that phenomenon. A personal theory of war is useless. What we absolutely require is a shared understanding that enables the development and execution of strategy, operational, and tactical plans. Professional officers must understand the influence of history and the interpretation of history through the lens of a theory of warfare on the evolution of Army and Joint doctrine as well as on the relevant policy for which war is waged. This knowledge will enable individual agility of mind required to adapt to the changing conditions of war. This is the essence of the art of strategy.

The US armed forces concluded the Iraq war in a manner that must be considered a victory: never defeated in battle, accomplished objectives that led to attaining the policy goal of delivering the security challenge to the Iraqis; and departing in accord with a nation-to-nation

3 For example, see James Mann, Rise of the Vulcans: The History of Bush's War Cabinet New York: Penguin, 2004); John Heilemann and Mark Halperin, Game Change: Obama and the Clintons, McCain and Palin, and the Race of a Lifetime (New York: Harper-Collins, 2010); Michael R. Gordon and Bernard E. Trainor, Cobra II: The Inside Story of the Invasion and Occupation of Iraq (New York: Vintage Books, 2007); Michael R. Gordon and Bernard E. Trainor, The Endgame: The Inside Story of the Struggle for Iraq, from George W. Bush to Barack Obama (New York: Vintage Books, 2013); and any of the books written by Bob Woodward.

4 Carl von Clausewitz, On War, edited and translated by Michael Howard and Peter Paret (Princeton: Princeton University Press, 1976), 111 
agreement in December 2011. This is something never done before in that region of the world - an Army leaving in accord with a treaty and not remaining indefinitely as an occupying power.

My war experience was primarily at the operational level of war and in operational level headquarters. My military and professional education, coupled with my experience, confirmed for me the purpose of the operational headquarters is to translate the tasks of policy and strategy into attainable tactical tasks. I am also convinced tactics without strategy is noise before defeat. ${ }^{5}$ Regardless how one defines strategy and policy, understanding the interrelationship of those two concepts and the role played by the operational level commander and staff is important. Of equal importance is an understanding of how strategy is designed, shaped, and adapted over the course of a campaign, all while maintaining an eye on accomplishing the initial purpose of the war. ${ }^{6}$

5 Attributed to Sun Tzu, this quotation is not in "The Art of War."

6 This essay was based on an opinion essay I wrote, "An Iraq War Planner Reflects on Lessons Learned," published at Time.com on 1 April 2013. I gratefully acknowledge the assistance of Greg Fontenot, COL (USA Retired), Professor Steve Lauer, LTC (USMC Retired), and my wife Kate Benson in the development of this essay. 



\title{
Commentaries and Replies
}

\section{On "Regionally Aligned Forces: Business Not as Usual"}

\author{
Richard H. Sinnreich \\ (C) 2013 Richard H. Sinnreich
}

This commentary is in response to the article, "Regionally Aligned Forces: Business Not as Usual" by Kimberly Field, James Learmont, and Jason Charland published in the Autumn 2013 issue of Parameters (vol. 43, no. 2).

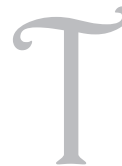

he authors of "Regionally Aligned Forces: Business Not as Usual" offer a comprehensive and forceful defense of the Army's regional alignment concept, and much of what they write is both enlightening and persuasive.

Notwithstanding the familiar conceit of each successive generation of leaders that what they are proposing is A Really New Thing, there is nothing revolutionary about regionally aligned forces. On the contrary, for many who served during the Cold War, especially NCOs, and who spent a good part of their careers bouncing back and forth repeatedly between East Cost installations and Germany or West Coast installations and Korea, regional alignment was a fact of Army life.

But there is no question that both the scale of the effort described in the article and the manner in which the Army proposes to conduct it differ materially from that earlier experience. The biggest changes are in the diversity of the locations to which soldiers will deploy and the increments in which they will do so.

Thus, in contrast with the individual deployment practices of the Cold War and the more recent brigade-based rotations sustaining operations in Iraq and Afghanistan, the RAF concept visualizes deployments of less than battalion or even company strength, more or less on the model of special forces teams. Indeed, the authors note, "While it is desirable to maintain habitual alignment at brigade combat team level, the realities of current defense missions make this aspirational rather than practicable," adding, "Already in the first year of regionally aligned forces execution, the Army has realized numerous efficiencies by being able to identify when to send squads rather than platoons."

There's nothing intrinsically wrong with that, and it certainly limits budget costs. Moreover, putting aside marketing rhetoric and the absurd notion that spending a month or two in Mali, say, is going to make its visitors Africa specialists, there is much to be said for exposing soldiers to geography in which they might conceivably have to operate one day and to foreign forces with whom they might find themselves allied (or to whom, in the worst case, they might find themselves opposed). In addition, giving small unit leaders a periodic taste of operational independence certainly has merit.

The costs that really should concern us, however, are not RAF's budgetary costs. They are its opportunity costs. The further the Army's

COL. Rick Sinnreich, USA Retired, is the military columnist of Lawton, Oklahoma's Sunday Constitution. His columns have been reprinted by The Washington Post, ARMY, and other journals, and he has edited or contributed to several recent works on military history, including The Making of Peace: Rulers, States, and the Aftermath of War (2009); The Shaping of Grand Strategy: Policy, Diplomacy, and War (2011); and Hybrid Warfare (2012). 
force structure shrinks - and right now, it looks as though we'll be lucky to preserve the 490,000 previously budgeted - the more difficult it will be to satisfy all claimants for incremental commitments while sustaining even a modicum of combat readiness. Anyone who ever has commanded at battalion or brigade knows how difficult it is to achieve both materiel and training readiness in the face of routine local support decrements. Committing soldiers and junior leaders in penny-packets to repeated overseas deployments will only compound the difficulty.

The authors recognize the problem. "Meeting combatant commanders' specific day-to-day needs potentially requires a lower level of collective training than do major combat operations," they note, "yet those same forces must be ready for the toughest fight, particularly as the total number available for that fight decreases."

For that reason, their all-too-correct lament that, "Balancing readiness for the most likely and most dangerous courses of action has never been more difficult" rings just a bit hollow. Whatever else it does or doesn't do, the RAF concept as described will only make that challenge more difficult.

\section{The Authors Reply}

\section{Kimberly Field, James Learmont, and Jason Charland}

OL (ret) Rick Sinnreich put his finger on the central issue of implementing Regionally Aligned Forces. He writes that in a less-than-490K force, Regionally Aligned Forces (RAF) makes it more difficult to ". . . . satisfy all claimants for incremental commitments while sustaining even a modicum of combat readiness." RAF is largely driven and embraced by former battalion and brigade commanders, but the dialogue about this point continues, centered around sufficiency-sufficiency in achieving readiness levels to conduct major combat operations and sufficiency in sustaining active relevance as an all-volunteer service.

It is worth reemphasizing that Regionally Aligned Forces include those forces aligned for high intensity major combat operations and crisis response, and not simply security cooperation activities. Forces are aligned based on all needs of Combatant Commanders (and these needs exceed both the capacity and capabilities of Special Operations Forces and the Marines).

Readiness has, and will continue to be, a topic of concern to Army senior leadership. Indeed, RAF is predicated on the necessity for decisive action training (combined arms maneuver and wide area security) as the critical baseline in underpinning the Army's ability to operate across the full spectrum of operations. Still, we ask, how much readiness is enough to meet the requirements of major combat operations requiring brigade level action, and also for the dispersed activity so in demand by Ground Component Commands? How much do these requirements reinforce each other? What specifically is the time required to move a sufficient number of units required for the most demanding operations plan, from 
company through battalion to brigade collective training? What is the end strength threshold at which we do indeed have to protect almost the entire force for brigade level action? Most importantly, how do we better understand readiness in terms of risk, resourcing, and reporting given current and expected requirements? We need to plan the building of readiness that will, with minimal risk, include missions undertaken by regionally aligned forces. We write that RAF will be fully implemented by 2017 . Getting well-tested answers to these questions is part of the reason why the full implementation will take time.

We assert that only by training in joint and coalition environments, in those areas of the world in which we will fight, will the force be able to adapt rapidly enough for future operations we cannot even envisionand certainly not from Fort Hood. As we stated previously, we see RAF as phase one of implementing the concept of Strategic Landpower. RAF are scouts, the Joint Force's best hope for being able to develop decisive outcomes in future fights. COL Sinnreich is right; RAF is not primarily about language and cultural expertise.

Finally, a $490 \mathrm{~K}$ force is not the Total Army. The Reserve Component contributes another 520K. From the example of a single National Training Center rotation, we know that it takes about 90 days of hard training to turn a National Guard Brigade Combat Team into a unit equally capable as an active duty brigade. How fast can we add them to the fight- three every 90 days? More?

In any event, as the Chief of Staff has said, we do not currently have the service dollars to conduct the collective training we desire; better our units are using other dollars to make the gains we outlined in the article and again here. 


\title{
On "Strategic Landpower in the Indo-Asia-Pacific"
}

\author{
Jeong Lee \\ This commentary is in response to the article, "Strategic Landpower in the Indo-Asia- \\ Pacific" by John R. Deni published in the Autumn 2013 issue of Parameters (vol. 43, \\ no. 3).
}

$\mathrm{n}$ his Parameters article entitled "Strategic Landpower in the Indo-AsiaPacific," Professor John R. Deni attempts to make the case that the United States Army "has significant strategic roles to play in the IndoAsia-Pacific region" which cannot be met alone by the United States Air Force and the Navy. ${ }^{1}$ Among these roles, Deni avers that the Army can provide ballistic missile defense (BMD) in addition to the Army's traditional role of providing defense and deterrence and Command, Control, Communications, Computers, Intelligence, Surveillance, and Reconnaissance (C4ISR) capabilities for South Korea, Japan, and Taiwan. ${ }^{2}$ Most importantly, Deni believes that in the Pacific theater, the Army can foster "allied interoperability" and bolster the strength of "less-capable partner militaries" better than its Navy and Air Force counterparts, because the US Army can "speak "Army" to its allies."

The implication is clear. In the sequestration era, the Army needs to justify its relevance in pursuit of America's geopolitical strategy in the Asia-Pacific. Although I agree to an extent with Deni's proposal for the Army's participation in what he refers to as "security and cooperation activities," the premises underlying his argument may be flawed for several reasons.

First, by arguing that many allies view the United States' presence positively because it "helps establish capabilities that support the rule of law, promotes security and stability domestically," Deni assumes that America still can and must retain the mantle of global leadership even though its image abroad has weakened considerably. According to the latest survey by the Pew Research Center's Global Attitudes Project, while the United States retained its favorable image over China at 63

Mr. Jeong Lee is a freelance writer and a contributing analyst for Wikistrat's Asia-Pacific Desk. Lee's writings have appeared in multiple online publications, including East Asia Forum, the Georgetown Journal of International Affairs, the World Outline, CIMSEC, the Naval Institute's blog, RealClarDefense, and Small Wars Journal. He writes on US defense and foreign policy issues as well as interKorean affairs. percent, many countries are nevertheless perplexed by America's unilateral actions on the world stage. ${ }^{5}$ Furthermore, security cooperation activities involving America's Asian allies may potentially anger the Chinese in the same manner that the Air-Sea Battle (ASB) concept has led, and could lead to, greater tensions with China. ${ }^{6}$

1 John R. Deni "Strategic Landpower in the Indo-Asia-Pacific," Parameters 43, no. 3 (Autumn 2013): 77 .

2 Ibid., 78-9.

3 Ibid., 82.

4 Ibid.

5 “America's Global Image Remains More Positive than China's But Many See China Becoming World's Leading Power," Pew Research Center's Global Attitudes Project, July 18, 2013, http:/ /www.pewglobal.org/2013/07/18/americas-global-image-remains-more-positive-than-chinas

6 Amitai Etzioni “Air-Sea Battle: A Dangerous Way to Deal with China," The Diplomat, September 3, 2013 http:/ / thediplomat.com/2013/09/03/air-sea-battle-a-dangerous-way-to-deal-with-china/ 
Second, by advocating that the Army also undertake an active role in BMD to "assure" our allies in the Pacific of our commitment as well as to "deter [potential] aggressors," Deni deliberately overlooks the fact that the Air Force and the Navy are already performing missile defense and, for this reason, undertaking such missions would prove redundant. ${ }^{7}$

This leads to the third point. Deni's argument that the Army is better suited for fostering "allied interoperability" because it "can speak Army" trivializes the fact other services have proven equally adept at or outmatched the Army in fostering interoperability among our Asian allies. ${ }^{8}$ One example is that of the annual Rim of the Pacific (RIMPAC) exercises hosted by the Pacific Fleet.

Fourth, he correctly argues that "confidence- and security-building measures will be critical" to reverse Chinese perception that it is being encircled by America's "pivot" to Asia; however, such activities are not without risk, especially given China's growing cyber capabilities. ' Indeed, as Larry M. Wortzel, the president of Asia Strategies and Risks, testified before Congress in July, China "is using its advanced cyber capabilities to conduct large-scale cyber espionage [against the United States]." ${ }^{10}$

For the Army to adapt better to fluid strategic dynamics in the Asia Pacific, it should speak jointness (rather than "Army") because sharing ideas and resources with other services and Asian allies guarantees efficient warfighting. One such example is the creation of the Strategic Landpower Task Force composed of the Army, the Marine Corps, and the Special Operations Command (SOCOM). ${ }^{11}$

Because recent wars in Iraq and Afghanistan have proven that the line between state actors and nonstate actors has blurred, the Army should selectively target and neutralize threats as they arise. To that end, the Army could expand its Special Operations Forces (SOF). Applied within the context of its Asia-Pacific strategy, the Army should, in tandem with the Navy and the Marine Corps, operate from remote staging areas "to project power in areas in which our access and freedom to operate are challenged" without constraints. ${ }^{12}$ Surgical SOF strikes may ensure that the scope of America's involvement in the Asia Pacific will remain limited without escalating.

Lastly, the Army must also do what it can to defend the homeland from cyberattacks emanating from China. However, as retired Admiral James Stavridis argues, "Cyber threats cannot be dealt with in isolation;

7 Deni, 80 .

8 Ibid., 81.

9 Ibid., 84 .

10 Larry M. Wortzel, Cyber Espionage and the Theft of U.S. Intellectual Property and Technology,Testimony Before the House of Representatives Committee on Energy and Commerce Subcommittee on Oversight and Investigations, July 9, 2013, http://docs.house.gov/meetings/IF/ IF02/20130709/101104/HHRG-113-IF02-Wstate-WortzelL-20130709-U1.pdf

11 Raymond T. Odierno, James F. Amos, and William H. McRaven, Strategic Landpower; Winning the Clash of Wills, Strategic Landpower Task Force, Washington, DC 2013, http://www.ausa.org/ news/2013/Documents/Strategic\%20Landpower\%20White\%20Paper\%20May\%202013.pdf

12 Sustaining U.S. Global Leadership: Priorities for 21 st Century Defense, Washington, DC: Department of Defense, January 2012, 4, http://www.defense.gov/news/Defense_Strategic_Guidance.pdf 
combating them requires full cooperation of the private sector [and other federal agencies]."13

The Army has a critical role to play in the Asia Pacific. But in the sequestration era where a leaner and smarter military must offer a wide range of options for the nation, the Army cannot just "speak Army" to stay relevant. Instead, it must speak jointness to become truly effective

13 James Stavridis “The Dark Side of Globalization,” The Washington Post, May 31, 2013, http:/ / www.washingtonpost.com/opinions/how-terrorists-can-exploit-globalization/2013/05/31/ a91b8f64-c93a-11e2-9245-773c0123c027_story.html 


\title{
On "Strategic Landpower in the Indo-Asia-Pacific"
}

\author{
James D. Perry \\ (C) 2013 James D. Perry
}

This commentary is in response to the article, "Strategic Landpower in the Indo-AsiaPacific" by John R. Deni published in the Autumn 2013 issue of Parameters (vol. 43, no. 3).

n "Strategic Landpower in the Indo-Asia-Pacific," John R. Deni argued quite correctly that the Army has a significant strategic role to play in this region beyond deterring war on the Korean Peninsula. He noted the Army must prepare to conduct disaster relief operations, engage in security cooperation activities, address transnational security challenges, and build relationships with foreign militaries. Furthermore, he stated the Army may have to engage in confidence-building measures with China akin to those conducted with Russia in connection with the Intermediate-Range Nuclear Forces (INF) Treaty, the Conventional Armed Forces in Europe (CFE) Treaty, and other agreements.

Deni contended that the above "strategic missions" would be jeopardized if Army end strength were significantly cut. Unfortunately, he did not make a convincing analytical case, as he did not even try to assess the current demands that such missions place on the Army. I believe these demands are not large, and am rather skeptical that these missions can justify sustaining a high number of Army personnel or any specific number of Army brigades or divisions.

The number of soldiers currently doing "security cooperation" missions does not appear large if Afghanistan is excluded. Disaster relief in any given year might require a few hundred to a thousand personnel per disaster. Moreover, disaster relief often employs airlift and sea-based assets, but rarely involves large ground forces. Indeed, the insertion of ground forces during disaster relief is often regarded as counterproductive for many reasons. The number of Army Foreign Area Officers is barely more than a thousand; how many more do we really need in order to "speak Army" to foreign militaries? Another important "military to military" program, the Military Personnel Exchange Program, stations under 500 US troops with foreign militaries. The number of military personnel assigned to the Defense Threat Reduction Agency (DTRA) for on-site inspections and treaty compliance is approximately one thousand. The DTRA would not need a great many more to monitor any agreements concluded with China. Thus, the Army would be on shaky ground attempting to justify a large force structure on the basis of any of the above missions.

The various elements of the US foreign military training program undoubtedly foster good relationships with foreign militaries and provide the United States with access and influence in foreign countries. Nonetheless, these programs do not provide a convincing justification

Dr. James Perry received an MA in Security Policy Studies and a PhD in History from George Washington University. He was a Visiting Fellow at the Hoover Institution, Stanford University. After completing his fellowship, he joined Science Applications International Corp, where he analyzed national security issues for US government and military clients. $\mathrm{He}$ is currently a Senior Analyst for a major aerospace corporation. 
for a large Army end strength. The Air Force, Navy, and Defense agencies conduct many of these programs, and many others take place in Army training and educational facilities that will exist even if the Army shrinks significantly. For example, foreign students will still be able to attend the Army War College when end strength falls to 490,000. Finally, the dollar value of foreign military training programs is a small fraction of the Defense Department budget, which suggests that these programs cannot support an argument for keeping the Army budget particularly high.

As for large-scale advisory efforts, in 2007 Dr. John Nagl recommended creating a permanent Army Advisor Corps of 20,000 personnel for this purpose. Even such a considerable force would be less than five percent of an Army of 490,000, and would not necessarily preclude further reductions in end strength (although perhaps at the expense of traditional combat forces). More importantly, Congress and the public are unlikely, after twelve years in Afghanistan, to accept the argument that we must maintain a large Army so that we can do yet another long, exhausting advisory effort sometime in the future.

In sum, Deni made a good case that strategic landpower can advance the nation's interests in the "Indo-Asia-Pacific" region. He did not prove, however, that the nation could not realize the advantages of strategic landpower with a smaller Army. If the Army can conduct security cooperation missions effectively with a smaller end strength, then that is a win for the nation as a whole.

\section{The Author Replies}

\section{John R. Deni}

ames D. Perry is certainly correct that my article does not include a detailed, worldwide troops-to-task analysis for the US Army. However, such a detailed analysis seems unnecessary to justify one of my central contentions that Perry appears to disagree with-specifically, that the Army's ability to perform its strategic role in the Indo-AsiaPacific theater, as well as its missions elsewhere around the world, faces greater risk if the Army is forced via unconstrained sequestration to cut personnel precipitously. The very recent history of the Army's experience in Iraq and Afghanistan seems to have proved this point, when the necessity of generating enough combat units forced DOD to remove US Army units from their deterrence and assurance missions in South Korea, cancel or downsize countless security cooperation events around the world, and even dip into the so-called "seed corn" by deploying training units based at the National Training Center in California and the Joint Multinational Training Center in Germany. Looking ahead, Dr. Perry may believe it will be easier for a dramatically smaller Army to meet the needs of the all combatant commanders around the world for security cooperation, assurance, deterrence, disaster response, cyber defense, homeland defense, ballistic missile defense, counterterrorism, and the 
myriad other operations and missions the Army is responsible for, but that would appear to fly in the face of recent events. ${ }^{14}$

The global troops-to-task analysis that Dr. Perry is after is really outside the scope of a 4,000-word essay. His own brief effort to tally up the numbers was certainly not comprehensive, and hence not compelling as a basis for judging whether the active duty Army should be $490 \mathrm{~K}$ strong or $300 \mathrm{~K}$ strong, and what level of risk would accompany any chosen end strength. Indeed, a full scope troops-to-tasks analysis is the kind of thing the entire Department of Defense is currently engaged in as part of the Quadrennial Defense Review (QDR) report. That report should, among other things, outline the major missions or broad objectives the Department will use to size and structure the force. Although the QDR report is months from publication at the time of this writing, one thing that seems very clear is that if sequestration remains, the active-duty Army is likely to drop below 490,000 personnel and 33 brigade combat teams (BCTs), perhaps to about 420,000. ${ }^{15}$ Outside experts agree that sequestration will likely cause a major cut in active duty Army forces and consequently in the number of active duty BCTs. ${ }^{16}$ Obviously, and according to these same experts, this will make it more difficult for the Army to perform its many missions. Just how difficult — and how much risk is associated with a smaller, less capable forces - remains to be seen, but the fact remains that a smaller military necessarily increases risk. Currently, it appears the country may be quite willing to tolerate a great deal of risk, at least in the short run, when it comes to its land forces. If so, the Army will be a less effective strategic tool in achieving US objectives not simply in the Indo-Asia-Pacific but around the world.

Meanwhile, Jeong Lee's critique is interesting, although not terribly compelling. At the heart of his commentary lies the mistaken view that I argue the Army is "better" at building interoperability than its sister services. In fact, I recognized in the article that, "air and naval exercises can build allied interoperability" as well, and I used the shorthand "speak Army" to encompass interoperability in the tactics, techniques, and procedures of land forces, vice those of air or naval forces. The issue is not whether the Air Force or the Navy can build interoperability with allied or partner military forces, or even whether they do it "better" (his word, not mine). Instead, the issue is whether those sister services can do so in the specific skill sets of the US Army. The answer to that question is most clearly no, just as the Army clearly cannot build interoperability in tactical fixed wing operations, mid-air refueling, or search-and-rescue missions at sea.

This distinction matters because land forces dominate the military structures of most Indo-Asia-Pacific countries. If the United States

14 Moreover, for a case-ballistic missile defense-in which the Army cannot meet today's combatant commander need even at active duty levels of well over $500 \mathrm{~K}$ personnel, see Steven Whitmore and John R. Deni, NATO Missile Defense and the European Phased Adaptive Approach: The Implications of Burden-Sharing and the Underappreciated Role of the U.S. Army (Carlisle, PA: Strategic Studies Institute, 2013), www.strategicstudiesinstitute.army.mil/pubs/display.cfm?pubID=1172

15 Lance M. Bacon, "Chief, Congress and DoD hammer out Army's future manning levels," The Army Times, October 7, 2013, www.armytimes.com/article/20131007/NEWS/310070003.

16 "Comparison of Team Choices," briefing delivered on May 29, 2013 at the Center for Budgetary and Strategic Assessments, www.csbaonline.org/publications/2013/05/ strategic-choices-exercise-outbrief/. 
proves unable or unwilling to engage those dominant bureaucracies and organizations within allied and partner defense establishments, it will undoubtedly be choosing to go down a less effective, less efficient path to fulfill its goals across the region.

Lee also contends that because the United States Air Force and United States Navy are performing air and ballistic missile defense operations in the Indo-Asia-Pacific region, Army efforts in this sphere are or will be redundant. Unfortunately, this view reflects a misunderstanding of the basic roles and missions of the United States military. Per US law, the Army is broadly responsible for defense from the land, so air and missile defense of assets or potential targets on land-the kind of thing the road-mobile Patriot system or the road-mobile Terminal High Altitude Area Defense (THAAD) system were built for-are Army missions. If Lee finds the Army's fulfillment of these missions in the Indo-Asia-Pacific region problematic, he must assume there are no targets on land that need defending from ballistic missile threats, or his argument is really with Title 10 of the US Code, not my article.

Finally, Lee implies that my proposal for the Army to tap into its strong record of implementing confidence- and security-building measures (CSBMs) to ameliorate the Chinese security dilemma is naive for not recognizing the risk of Chinese espionage occurring during CSBM activities. In fact, I made this exact point in my article. Certainly Chinese espionage, including through cyberspace, is a risk that must be carefully managed when it comes to CSBM implementation, but as I went on to argue, if the Chinese use CSBM activities to collect intelligence on the United States military, so what? At least in part, that is the very point of CSBMs. The same occurred during the Cold War and its aftermath between US and Soviet/Russian arms control inspectors, observers, and specialists - each side "collected" on the other during exercise observer missions, authorized overflights, and intrusive on-site inspections. The anecdote I relayed in the article-in which Chinese military officials were literally incredulous when shown data on the paltry array of U.S. forward-based military forces and bi- and multilateral security agreements in the Indo-Asia-Pacific theater today relative to that arrayed against the Soviet Union at the height of the Cold War-underscores the notion that greater transparency with China is necessary to avoid any Sino-American conflict borne of misunderstanding.

In sum, Lee is certainly correct that the US Army needs to maintain and build on the jointness it shares with its sister services, particularly in an era of austerity. By the same token, US policymakers need to take advantage of all the tools at their disposal in pursuing American interests in the Indo-Asia-Pacific theater, not simply the ones that fit neatly into preexisting paradigms. 


\title{
On "Imbalance in the Taiwan Strait"
}

\author{
David Lai
}

This commentary is in response to the article, "Imbalance in the Taiwan Strait" by Dennis V. Hickey published in the Autumn 2013 issue of Parameters (vol. 43, no. 2).

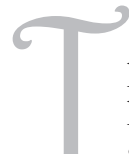

his is a timely discussion of US arms sales to Taiwan. The author has done a great job drawing attention to the evolving security situation across the Taiwan Strait and placing the debates in the US policy and analyst circles about America's options on this thorny issue in perspective.

While well presented, this article would have been better had the author been more straightforward on Option 1 and included recommendations for Chinese policymakers regarding predicaments with the Taiwan Relations Act of 1979 (TRA) and US arms sales to Taiwan. With respect to this option, the author should have stated that though it is worthwhile to call for the United States to terminate arms sales to Taiwan, there is practically no chance of this happening as long as the Taiwan issue remains unresolved.

As for recommendations, the author could have pointed out that the main driver for US arms sales to Taiwan comes not from the alleged American ill intent and economic interests, as many Chinese analysts have long charged, but from Taiwan's need for security. The reason is as simple as Business 101: if Taiwan wants more weapons, the United States is obliged to sell, although not unconditionally; if Taiwan does not want more arms, the United States cannot force Taiwan to buy. The fact is that the Taiwan government, whether under the administration of the pro-independence party (the Democratic Progressive Party) or the pro-eventual unification one (the Kuomintang or Nationalist Party), has repeatedly asked for more arms from the United States.

Nations seek arms when they are concerned with the specter of war; they lay down arms when peace is secured. China should see that the solution to the issue of US arms sales to Taiwan lies in cross-Taiwan Strait relations. China should have a better chance to affect the arms sale business with its efforts on cross-Taiwan Strait relations. Demanding the United States to abandon this business is like putting the cart before the horse- the efforts are not going anywhere. China's insistence on terminating US arms sales to Taiwan as one of the three preconditions for improving United States-China military-to-military relationship is a prime example (the other two preconditions are stopping US military reconnaissance operations in the Chinese-claimed maritime exclusive economic zones and removing US restrictions on military exchange and technology transfers to China). The setbacks following each US authorization of arms sales to Taiwan (i.e., Chinese suspension of military-to-military contacts with the United States) have been counterproductive and dangerous at a time when the two nations have a high "trust deficit" regarding each other's strategic intent, and a low

Dr. David Lai is a Research Professor of Asian Security Affairs at the Strategic Studies Institute of the US Army War College. His recent publications are "Doubts on China's New Model for Great Power Relations"'SSI Op-Ed, October 2013), "Asia Pacific: A Strategic Assessment" (SSI monograph, May 2013), and The United States and China in Power Transition (SSI book, December 2011). 
understanding of each other's operational rules of engagement. It is time to make adjustments.

\title{
The Author Replies
}

\author{
Dennis V. Hickey
}

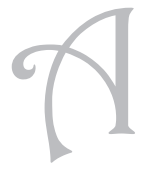

number of interesting points are raised in this commentary; however, I disagree with others. Let me explain.

First, with respect to Option 1 (terminating arms sales to Taiwan), Dr. Lai suggests that I should have noted there is "practically no chance of this happening." But some do not share this opinion. In fact, in 2011, Representative Ros-Lehtinen (R.-Florida) claimed she had organized Congressional hearings in the US House of Representatives because "some politicians" had begun to pressure the Obama administration to "abandon" Taiwan. Let's remember that many Americans were stunned by President Richard Nixon's announcement in 1971 that he would journey to China to meet Chairman Mao Zedong. Millions were also surprised when the Reagan administration announced on August 17, 1982, that the United States would reduce its arms sales to Taiwan and eventually terminate arms transfers. Such episodes help remind us that anything is possible in international politics.

Second, Lai appears to quarrel with the assertion that economic considerations may serve as a "driver" for US arms sales to Taiwan. He should carefully review the wording of those studies supporting arms sales and the petitions submitted to President Obama. In fact, when commenting on the sale of new warplanes to Taiwan, the September/ October 2011 edition of The Taiwan Communiqué, a publication financed by Taiwan separatists based in America, contends that it is "the economic argument that will be the main reason why Congress will attempt to override the decision and force the administration to go ahead with the $[\mathrm{F}-16]$ sale."

Third, Lai claims that both major political parties in Taiwan always support US arms sales. This is incorrect. During the 1990s, the DPP opposed massive arms purchases (party documents described them as a waste of money). The DPP only changed its position after capturing the presidency in 2000. Not surprisingly, the KMT then did a complete reversal and opposed such purchases. This explains why a massive arms sales package offered by the Bush administration in 2001 was not purchased by Taiwan. Domestic politics always plays a big role in Taiwan's arms purchases.

Finally, Lai suggests that "the solution to the issue of US arms sales to Taiwan lies in cross-strait relations." He is correct. In an article entitled "Wake Up to Reality: Taiwan, the Chinese Mainland and Peace Across the Taiwan Strait," (The Journal of Chinese Political Science, Volume 18, No. 1, Spring 2013, pages 1-20), I argued that "it will be difficult for the two sides to sustain the momentum in cross-strait relations unless Beijing - and to some extent Taipei-begin to recalibrate their relationship in a more pragmatic way and adopt some new thinking on the 
concepts of sovereignty and the political status of the ROC. In short, they need to figure out a way to acknowledge the fact that both the ROC and PRC exist." To be sure, it is time for Beijing to "wake up to reality." 


\title{
On "US Options in Syria"
}

\author{
Nathan K. Finney \\ (C) 2013 Nathan K. Finney
}

This commentary is in response to the article "US Options in Syria" by David S. Sorenson published in the Autumn 2013 issue of Parameters (vol. 43, no. 3).

$\mathrm{n}$ a time when interservice rivalries seem to be only growing (see the Autumn issue's Commentaries and Replies between Major General Charles Dunlap and Dr. Conrad Crane, for instance), I was pleased to read the thoughtful and balanced article by the Air War College's Professor David Sorenson, "US Options in Syria." His realistic and knowledgeable approach to the region and its largest internal conflict was refreshing.

Professor Sorenson's analysis and description in this article reflects well on the war colleges. He begins by detailing American interests in Syria and the region, including ending the civil war, reducing the Shi'a-Sunni divide, addressing WMD issues, and containing the adverse effects of the civil war on allies in the region. While these are all admirable interests, Sorenson does not discuss whether these interests are vital, important, or only peripheral. He does state that our interests in the region are important and Syria is a pivotal country, but he does not elaborate. Additionally, Sorenson states that, "It is also in America's interest to terminate major internal wars in the region if it has the means and ability to do so, and at an acceptable cost." Why is this the case? I would argue (and did in a recent article in the Infinity Journal on Syria) that our interests in Syria are peripheral at best and that it is not always in our interest to meddle in internal wars, whether they are in the Middle East or other less strategically important areas like Africa.

After describing American interests in Syria, Sorenson discusses US options developed to date by our national security apparatus, most clearly articulated in the memo by the Chairman of the Joint Chiefs of Staff General Dempsey to Senator Carl Levin. These options are the anticipated ways available to the United States, including everything

MAJ Nathan K. Finney, USA, is a member of the Infinity Journals Special Advisory Group and has written on issues that involve strategy, building partner capacity, security sector reform, and security force assistance. He holds a Master's in Public Administration from both Harvard University and the University of Kansas, as well as a B.A. in Anthropology from the University of Arizona. from training the opposition in Syria to establishing a no-fly zone and punitive strikes by stand-off weaponry.

Using these options as a framework, Sorenson describes end-state conditions that could be achieved in both winding down the civil war and preventing its violence affecting neighboring countries. His analysis is a great elaboration on the obstacles that face the development of options to address Syria. In ending the civil war, Sorenson recognizes many truths, to include the fact that the Assad regime is fighting an unlimited war for its own survival, while the United States is fighting a limited war to achieve the best outcome in a bad situation. He also recognizes the view that American support is not designed to bring the conflict to a conclusion, but rather to prolong the fighting to exhaust all parties. Why is this a bad approach? As strategist Edward Luttwak stated 
in The New York Times in August, "There is only one outcome that the United States can possibly favor: an indefinite draw."

Discussing the obstacles to contain violence to prevent affecting neighboring countries, Sorenson approves of a containment of Syria, recognizing the differences between the Cold War era containment, which was focused on keeping the USSR (and to some extent China) out, while containment for Syria would require keeping the actors in. This aim would typically call for sealing Syria's borders, threatening the regime by air, assassinating regime officials, or inflicting damage to regime supporters. Sorenson admirably acknowledges that this kind of coercion by punishment would be too costly and difficult_-largely given the asymmetric value of a peaceful solution, and providing Assad little incentive to give up power.

This brings Sorenson to his solution: containment of the violence in Syria through the support of neighboring countries. His ideal approach would be to support neighbor militaries, share info, maintain air and naval forces proximate to Syria, and threaten Assad for any moves outside of Syria. A part of this approach would be to stop the flow of weapons to both sides of the conflict. Even if it were feasible, stopping the flow of weapons to Syria removes one of the few points of leverage we have in the region. In order to create a balance between the belligerents, our support, or lack thereof, can help ensure each party is balanced, ultimately exhausting all parties - from Assad to Iran, or Hezbollah to Sunni extremists. This was the core argument made by Luttwak in The New York Times op-ed referenced earlier.

Finally, while Sorenson postulates that our best approach is through the support of neighboring states, he barely addresses one of our most potent military capabilities - security force assistance. He does mention military assistance to Lebanon, but does not address what we should do to ensure the ability of Turkey, Jordan, Israel, and Iraq to contain Syria. Granted, most of these nations already have security assistance programs with the United States and possess some capacity to secure their borders, but this is an aspect I think could have used more elaboration.

Overall, I was very impressed with "US Options in Syria." Sorenson's realistic approach to an intractable problem was reinforced with expert analysis. Despite a few disagreements on the value of our interest in the region and ways to achieve them, I agree that "Containment is in the interests of all countries bordering Syria, and the White House must stress and build on that point in its own policy." This policy should be focused on containing instability and violence from leaving Syria through support to its neighboring states. On this, the author and I are in violent agreement. 

Armed Nonstate Groups

\section{Global Security Upheaval: Armed Non-state Groups Usurping State Stability Functions \\ By Robert Mandel}

Reviewed by Dr. José de Arimatéia da Cruz, Visiting Research Professor at the US Army War College at Carlisle Barracks, PA, and Professor of International Relations and Comparative Politics

R

obert Mandel's Global Security Upheaval: Armed Non-state Groups Usurping State Stability Functions is a tour de force in the field of security studies. The author's arguments and recommendations turn the Westphalian state system on its head. In that system, rule or monopoly over the legitimate use of physical force is considered the exclusive domain of the state. Furthermore, the state's ability to provide for the welfare and security of its citizens is derived from its presumed social contract between the rulers and the ruled. However, Mandel's Global Security Upheaval calls into question the common belief that central governments are the sole source of a nation's stability and argues that subnational and transnational nonstate forces are major sources of global instability in an insecure world. According to Mandel, "the steady concentration of power in the hands of states, which began in 1648 with the Peace of Westphalia, is over, at least for a while" in part because "of the ability of armed individuals and armed nonstate groups to undertake physical coercions." In this post-Westphalian system there are diverse sources of rule or monopoly over the use of force rather than just the mighty Leviathan. In addition, armed nonstate groups may enjoy a form of Weberian legitimacy if they step into a power vacuum and provide for critical public needs.

Mandel questions the conventional thinking about international stability. His argument rests on four main assumptions. First, states and intergovernmental organizations are the dominant focus of authority in global society. Second, armed nonstate groups are legitimate spoilers disrupting security and triggering political disorder and violence. Third, the public consistently demands state government protection, and private bodies can enhance security only if they do not rely on the threat or use of violence, as with transnational market-based or humanitarian organizations. Fourth, if a state is not providing stability, a strategy of strengthening and expanding governmental capacity would be a sensible response to the government deficit.

Mandel also provides a set of counterpropositions. For example, areas exist where it makes little sense to rely on central state governments for stability; attempts to bolster such governments to promote stability often prove futile; armed nonstate groups can sometimes provide local stability better than states; power-sharing arrangements between states and armed nonstate groups may sometimes be viable; and these changes in the international setting call for major analytical shifts and significant deviations from standard responses. Mandel believes a state must follow these strategies to enhance its national security.

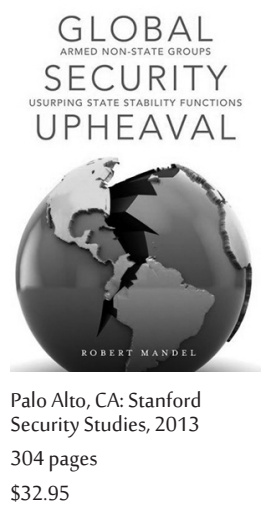

$\$ 32.95$ 
Moreover, changes in the global supply and demand for protection are the primary reason for the rise of armed nonstate groups. As the state diminishes its ability to fight unconventional threats and while there is an increase in public demand for protection, armed nonstate groups will proliferate around the world to fill the vacuum left by the state. As the security of the state and individuals becomes grounded in private enterprise, armed nonstate groups in locales where the state has lost control could become the only viable alternative for stability. Mandel argues that there are areas of the world where it makes little sense to rely on state government for stability. In fact, argues Mandel, attempts to bolster such governments' efforts to promote stability often result in the opposite outcome: more violence and less security. Figure 1 summarizes Mandel's argument of supply and demand of nonstate actors for protection.

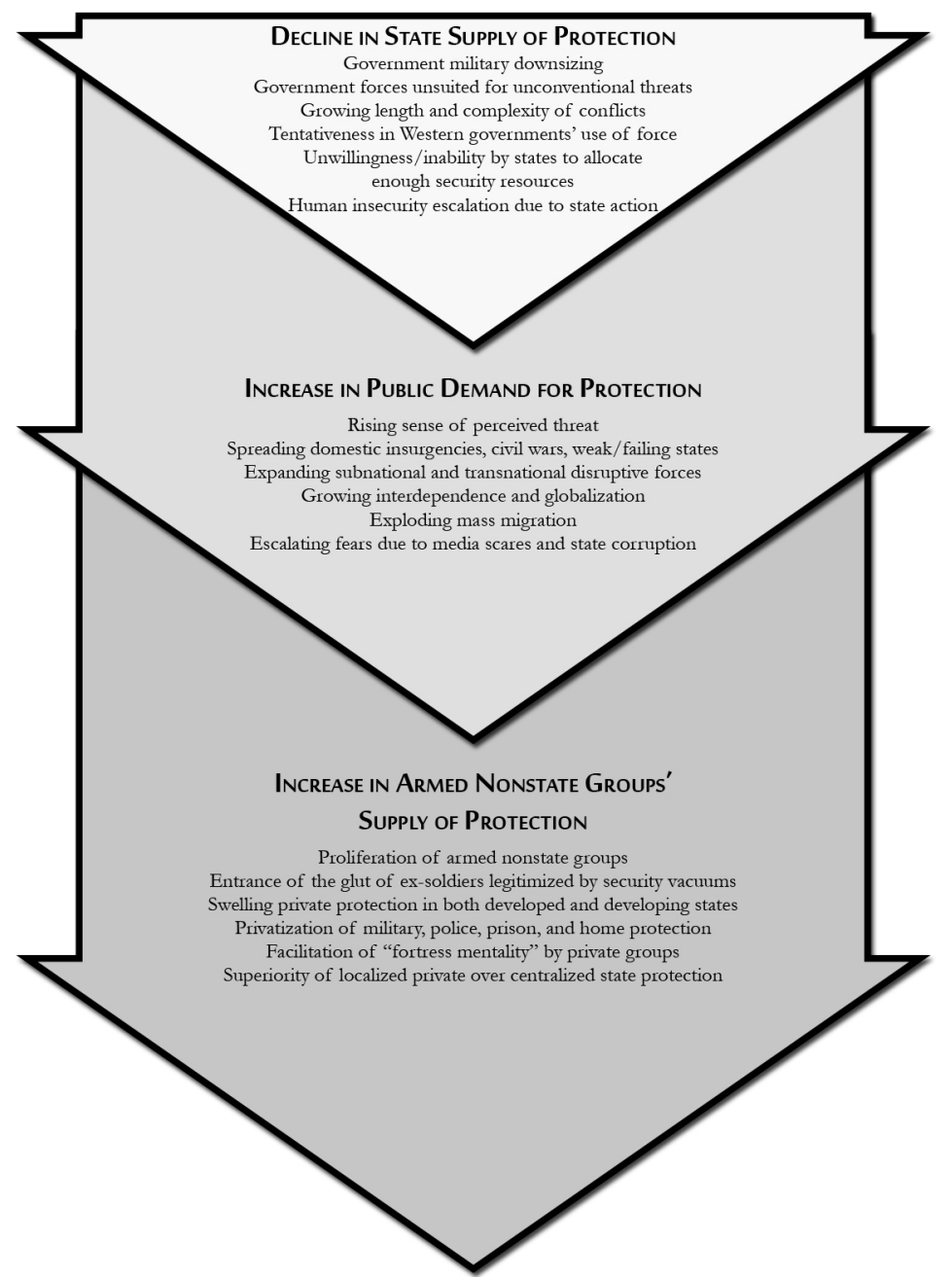

Figure 1. Mandel's argument of supply and demand of nonstate actors for protection.

There are several elements in this text that make it unique in relationship to other works. First, each chapter uses figures to highlight 
key conceptual points, allowing readers to gain a quick understanding of a section's main thrust and to compare at a glance multifaceted findings across topics and sections. Second, the book contains extensive cross-references allowing readers who want more background on a topic to find the appropriate discussion in another section easily. Mandel explores the question whether the mighty Leviathan state is willing to coexist with a "parallel state" or a "state-within-states" to provide security and stability in the future. Mandel's answer is obviously yes. Figure 2 illustrates Mandel's vision regarding attitude changes for alternative security governance.

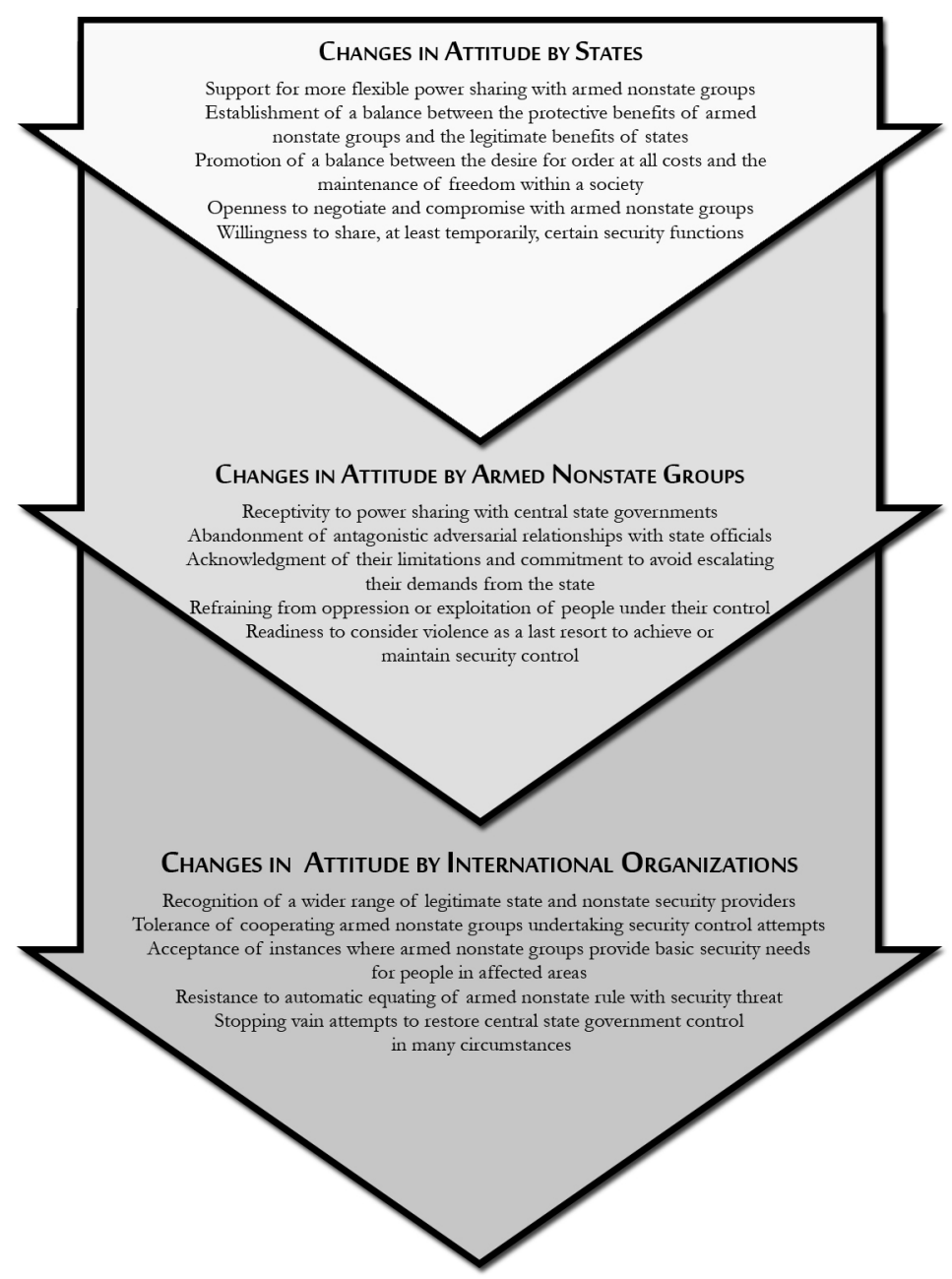

Figure 2. Mandel's proposed attitude changes necessary for successful alternative security governance.

In conclusion, I recommend this book to anyone interested in global security studies and future military leaders. This text can be especially useful to students at the US Army War College, many of whom will have to face the dilemma raised by Mandel. 


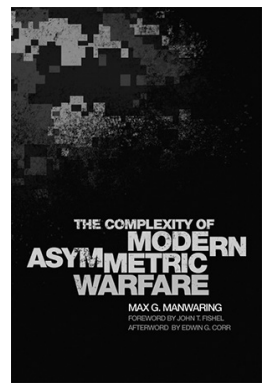

Norman: University of Oklahoma Press, 2012 224 pages

$\$ 45.00$

\section{The Complexity of Modern Asymmetric Warfare} by Max G. Manwaring

Reviewed by Robert J. Bunker, Distinguished Visiting Professor and Minerva Chair at the Strategic Studies Institute, US Army War College

be Complexity of Modern Asymmetric Warfare is the final volume in the

Manwaring twenty-first century conflict trilogy along with Insurgency, Terrorism, and Crime: Shadows from the Past and Portents for the Future (2008) and Gangs, Pseudo-Militaries, and Other Modern Mercenaries: New Dynamics in Uncomfortable Wars (2010) also by University of Oklahoma Press. The author-Max Manwaring, a Professor of Military Strategy at the Strategic Studies Institute, United States Army War College-is a prolific and veteran scholar with a wealth of expertise (including extensive field research) in Latin America along with an in-depth knowledge of numerous forms of insurgent and post-modern variations of warfare, which leverage psychological, temporal, and other unconventional capabilities.

The work is composed of a foreword (by John T. Fishel), preface and acknowledgements, and an introduction; the main section of seven chapters written by Manwaring; followed by an afterword (by Edwin G. Corr) and concluding sections composed of notes, a bibliography, as well as an index. Both former US Ambassador Corr and Professor Fishel (emeritus) are long-time Manwaring associates who have written informative and strategically valuable essays that highlight the work's focus on irregular asymmetric revolutionary conflicts. The book's seven chapters focus on historical conflicts in Algeria and El Salvador (Chapter 1); Sendero Luminoso in Peru (Chapter 2); vignettes of al Qaeda (in Spain); Cuban popular militias, gangs and organized crime in Haiti, and the Primeiro Comando da Capital (PCC) in Brazil (Chapter 3); the Russian politicized youth group Nashi (Chapter 4); transnational organized crime, gangs, and corrupted elites in Guatemala (Chapter 5); cyber and biological warfare (Chapter 6); and unconventional conflict futures (Chapter 7). Leading into the conclusion, each of the previous six provide key points and lessons as chapter summations.

As a colleague of Manwaring, I've always been amazed at his ability to draw upon unique and esoteric resources in his writings, including personal author interviews. The book's references are solid with an emphasis on scholarly works from the last ten years. The author not only has kept up with the literature in this area but also is responsible for shaping it and being one of its more creative contributors. The book's main arguments and "lessons learned" focus on the rise of irregular asymmetric revolutionary conflicts waged by both state and nonstate actors alike. These conflicts cause us to redefine our long-standing concepts of warfare. What we are seeing is the blurring of crime, warfare, gang activity, and the like. These are new actors-both state and nonstate groups - who may wage war and there is a new center of gravity based on information/media developing along with a new definition of victory. Furthermore, our interpretations of power and the purpose and motives of war are changing. The end result-I agree with the author-is that conventional warfare is by comparison much easier to engage in. What we are now facing is conflict that is multidimensional, 
multilateral, multiorganizational, and total - an unrestricted, brutal, and more complex form of organized and hypercompetitive political violence.

The major policy suggestions advocated to contend with the new types of conflict (wars) focus on five fundamental educational and organizational imperatives: a) our civilian and military leaders need to learn about subversion and insurgency techniques and understand strategic and political-psychological implications of operational and tactical actions; b) civilian and military personnel must benefit from enhanced and revitalized interagency cooperation, cultural awareness and language training, and combined (multinational) exercises to be effective; c) leaders need to understand that increased intelligence capabilities are required for small internal wars; d) our peace enforcers must also be warfighters to contend with more sophisticated nonstate political actor conventional and unconventional weaponry; and e) governmental restructuring is necessary to achieve an effective unity of effort drawing upon civilian and military instruments of national power and obtain an agreed upon political end state in our foreign conflicts.

Positive aspects of the book-besides the main arguments and important US defense policy suggestions contained within it-include the chapter focuses that highlight some very informative case studies. The reviewer found the Sendero Luminoso, Primeiro Comando da Capital (PCC), and Russian Nashi essays of great interest due to a general lack of exposure to those topical areas. The gaining of insights and context for these groups was in itself added value. A negative aspect of the work, if that is even a fair characterization, is that it seeks to peer into the "fog of still emerging conflict." As a result, the reader is left at times with both a hazy vision of emergent forms of warfare and of the opposing forces the United States may be facing.

In summation, the work-and its two predecessor volumes-is of great relevance and value to senior members of the US defense community. While some of the discussions and analysis in the work may not be clear and crisp, even approaching the philosophical, Manwaring offers key mosaic pieces to help us understand the complex puzzle-which merges war, insurgency, revolution, terrorism, criminality, cyberconflict, and a host of other elements - into that which is twenty-first century conflict.

\section{Al-Shabaab in Somalia: The History and Ideology of a Militant Islamist Group 2005-2012 \\ By Stig Jarle Hansen}

Reviewed by Richard J. Norton, Professor of National Security Affairs at the US Naval War College

s the Kenyan government is still trying to piece together what actually happened during al-Shabaab's 21 September 2013 attack on Nairobi's Westgate shopping mall, this is a most timely book. Al-Shabaab, at least for a time, was the most favored and successful of al Qaeda's so-called affiliates, racking up impressive victories and controlling large areas of the Somali countryside, including the capital Mogadishu. This

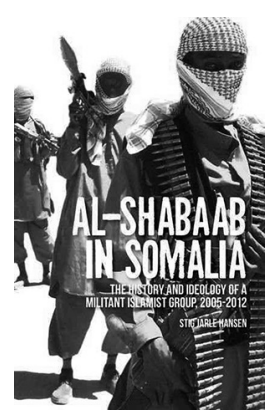

Oxford: Oxford University Press, 2012

208 pages $\$ 31.80$ 
period was followed by one of significant setbacks leading some analysts to predict the incipient demise of the organization. Clearly, these predictions were premature.

Scholar and author Stig Hansen has put together a remarkably detailed account of al-Shabaab's history. The book is filled with densely packed accounts of numerous Somali clans and their associated leaders and activities. While this level of detail may seem daunting to some, the book is still of great value to the lay reader. It is of greater utility to those analysts and practitioners who need or want to know about recent Somali history, or the rise of a surprisingly effective terrorist organization that may serve as a model for other such groups in the future.

Hansen comes from that small breed of what might be termed "adventure scholars"—although he himself might disagree with being identified as such. He does not rely on secondary source material but has travelled widely through Somalia for years and is personally familiar with many of the members and leaders of the movement. As a result, his description of events carries a powerful sense of legitimacy. While it is possible to debate what Hansen's observations mean, there is no doubting their authenticity.

There are surprises in this book. For example, it is easy to forget alShabaab's very modest beginnings. For example, in 2005, the movement could boast only 33 members. Within five years, they were nearly running southern Somalia. Hansen shows the reader how this happened. In the telling there are lessons and significant points to consider for those who wish to understand, and to potentially oppose, such groups.

The degree to which al-Shabaab used international events and a militant Islamic ideology was not insignificant. As Hansen chronicles, this broader dimension helped the movement's leaders align with disparate Somali clans and draw in significant numbers of foreign fighters and financing from not only Africa but also Asia, Europe, and even the United States. At the same time, al-Shabaab had to be relevant on the local clan level, which required them to be responsive to Somali issues that had little or nothing to do with a globalist ideology. Indeed, as al-Shabaab gained support among Somali clans, starting with some who were being sore-pressed by larger, more powerful groups, its leaders found themselves in a position similar to that of some politicians who, having come to power on glowing promises, now had to deliver.

This meant al-Shabaab was required to govern. It had to provide areas of stability where none had previously existed, ruling as neither an exploitative warlord nor a corrupt Somali government-neither of which Hansen argues provided real human security for Somalis in their areas of control. This was never an easy task and was often compounded by such adverse factors as drought and internal clan politics.

This is not to imply that the leaders of al-Shabaab were some romantic Robin Hood-like figures. They raised money through taxes and provided a form of justice through strict Sharia courts. They recruited heavily from local clans and established a powerful secret police, the Amniyat. The group relied on assassinations, roadside bombs, and suicide attacks in their rise to power. Interestingly, the majority of the suicide attacks were said to have been carried out by non-Somali members of the group. 
At the same time, Hansen also makes it clear that al-Shabaab's link to al Qaeda was always more than just lip service. Although not centrally directed by al Qaeda, the relationship is important to both organizations. While al-Shabaab must follow a "Somalia-first" policy of necessity, its globally oriented ideology remains aligned with the larger group. One point where the local and global are able to be conjoined by al-Shabaab is the ability to blame any adversity on the United States or African actors identified as US proxies.

Al-Shabaab has also displayed a talent for creating a powerful propaganda arm and not above dealing with criminal elements-most notably Somali pirates - when it was beneficial to do so. In the latter case, al-Shabaab did not go to sea; it simply demanded a "piece of the action" from those who did.

Hansen's account also reminds the reader that violent extremist groups embrace terror and irregular warfare as tactics of choice because they are not capable of engaging their opponents in a more conventional fashion. Although al-Shabaab was able to hold its own against the forces of the Transitional Federal Government, it was unable to do so against Ethiopian, Kenyan, Ugandan, and African Union military troops. The success of these forces, whether acting independently or as allies, speaks favorably of their military skill and capability.

Al-Shabaab's subsequent defeat cost them territory, created dissension among the group's leadership, and led to a loss of credibility and defection by clans that were previously loyal. While not destroying alShabaab, the military victories obtained by other African forces serve as a reminder that violent extremist groups suffer much from loss of reputation and that bombing shopping malls and assassinating opposition leaders is what they do when they cannot hold their own against conventional forces. This lesson should not be lost on those who hope to defeat such organizations.

But Hansen also reminds us that al-Shabaab is resilient. The Amniyat is still a force with which to be reckoned and a large amount of Somali territory is still under al-Shabaab control. The organization can obviously still mount cross-border actions and it is unlikely that its leadership will not seek to regain their former positions of power.

It would have been interesting if Hansen had discussed al-Shabaab's military operations in greater detail as to tactics, training, command and control, and so on. This is not to imply that he ignores these areas, just that readers with a particular interest in such things may be left wanting more.

One could also wish Hansen had expanded this work to include more analysis to rest alongside his powerful historical account. Given his long and deep exposure to the group, it would be valuable to know what he thinks the chances of integrating al-Shabaab into a legitimate Somali government and what the al-Shabaab story means to Africa and the world.

That said, until the distant and unlikely day when something better comes along, Al-Shabaab in Somalia is likely to be the definitive book on the subject. 


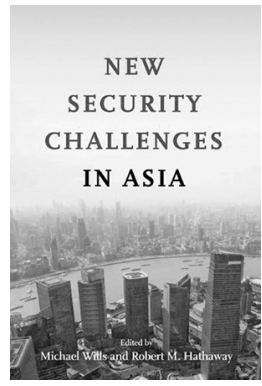

Washington, DC: The Woodrow Wilson Press, 2013

273 pages

$\$ 55.00$

\section{New Security Challenges in Asia Edited by Michael Wills and Robert M. Hathaway}

Reviewed by Jeong Lee, a freelance writer and contributing analyst for Wikistrat's Asia-Pacific Desk

1 ew Security Challenges in Asia (eds. Michael Wills and Robert M. Hathaway) is a collection of scholarly essays arguing that Asian security issues are determined by "transnational elements" that are shaped as much by external sources as the "preferred responses" of the actors involved. For this reason, the contributing writers focus on four core aspects of Asian security dilemma: water and food security, responses to pandemics, and transnational crimes, including cyberwarfare and terrorism. But as Wills and Hathaway concede in the introductory essay, such challenges are hardly "new." Indeed, the book shows how complex foreign policy threats manifest themselves as an amalgamation of old and new challenges.

The book is divided into ten chapter-length essays. In each chapter, authors examine case studies and follow them with policy recommendations for American and Asian policymakers. The editors set the tone for the discussion by laying out factors hampering effective responses to transnational threats to Asian security which may ultimately undermine the legitimacy of the state actors involved. Hathaway and Wills argue that what makes it difficult to manage these challenges may be the complexity and the rapid pace with which they threaten the security of the region and the attendant problems associated with integrating the "new frameworks of cooperation" due to the lack of consistent policy approaches and capabilities.

Although none of the essays in this volume explores the military dimensions of security challenges, defense policy mavens and military officers may derive great insights from chapters on water security, cybercrimes, and conflict and transnational terrorism. For instance, in Chapter 2 , Kenneth Pomeranz examines how limited access to water can lead to potential conflicts in the Himalayan-Tibet region due to domestic unrest over food and water security concerns.

Eric A. Strahorn delves into the historical roots behind conflicts over the Indus River Basin in Chapter 4. Strahorn argues that while the Indus Waters Treaty has been a political success, it ultimately "lacks flexibility" because it does not adequately address ecological dimensions of water usage by China, India, Pakistan, and Afghanistan. Strahorn further argues that competition for the control of water flow may ultimately lead to interstate conflicts and potentially derail America's security interests in the region.

In Chapter 9, Justin V. Hastings examines how post-colonial legacies in Southeast Asia have combined traditional instability with modernity to give rise to terrorism that continues to bedevil Southeast Asian states. To illustrate how Southeast Asia's porous "political and economic networks" can complicate both economic policies and counterterrorism efforts, Hastings examines two case studies. Each case illustrates how imperfect border control can foster what Hastings calls "illicit political 
and economic networks." Since terrorism in the aforementioned regions can undermine American interests, Hastings argues that the United States should "reshape" the security environment in Southeast Asia by aiding its allies at all governmental levels.

Adam Segal's essay in Chapter 10 examines how cybersecurity threats may undermine the underpinnings of global networks due to the rapid pace with which the Internet has spread and the difficulties of identifying perpetrators of cybercrimes. For these reasons, Segal argues that the militarization of cyberspace perpetuates traditional interstate rivalries. To prevent cyber threats from spiraling out of control, Segal suggests establishing the definition for what may constitute cyberattacks. Further, he argues the United States should combat cyber threats by fostering a "regional approach" to addressing cyberwarfare.

For diplomats and international relations scholars, this book may be impactful as it forces them to look beyond the confines of the existing international relations theoretical frameworks. As if to bear this out, case studies cited by the contributors demonstrate that no traditional international relations theories can easily explain the underlying causes of the challenges and threats posed by the plethora of elements involved nor can diplomats and scholars readily derive solutions from them.

The book, however, is not without its flaws. For one, military planners may find it difficult to apply lessons from the essays in the book. My chief complaint is the authors do not address the military dimensions of the transnational elements threatening Asian security. For instance, the authors dealing with water security, transnational crime, and cyber threats could have included policy recommendations for how the US armed forces can successfully deal with the new security challenges.

Furthermore, the contributors' American-centric policy recommendations fail to address solutions from the viewpoints of allies who supposedly need our guidance. To give a few examples, Robert Pomeroy's recommendations for resolving the fishery crisis in Southeast Asia in Chapter 5 entail top-down approaches directed by Washington, whereby the writer believes the United States must play a vital role in fostering sustainable growth and governance. Also, Segal's solutions for dealing with cyber threats are flawed in that they fail to account for the recent diplomatic embarrassments wrought by the revelation that the National Security Agency has been eavesdropping on America's chief allies.

The aforementioned shortcomings notwithstanding, New Security Challenges in Asia may serve as an informative guide for how the United States can successfully rebalance to Asia. As the writers of this volume show, where little or no military solutions exist to deal with new challenges, the United States can lead from behind by relying upon its soft power. 
Policy, Terror, \& ESPIONAGE

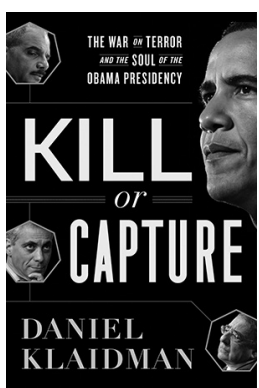

New York: Houghton Mifflin Harcourt, 2013 304 pages

$\$ 14.95$
Kill or Capture: The War on Terror and the Soul of the Obama Presidency

\section{By Daniel Klaidman}

Reviewed by Dr. W. Andrew Terrill, Research Professor at the Strategic Studies Institute, US Army War College

aniel Klaidman's Kill or Capture provides an in-depth examination of the Obama administration's policies on terrorism-related issues including Guantanamo Bay prisoners, harsh interrogations, military commissions, and the use of armed drones to strike against terrorists. According to Klaidman, President Obama had emerged as a foreign policy realist by the time he was elected and repeatedly proved himself to be "ruthlessly pragmatic" on terrorism issues despite his liberal instincts. An ongoing focus of this book is the legal and policy disagreements within the administration and the ways in which these struggles influenced the internal debate on a range of contentious issues. The two most important factions within the administration were sometimes slyly referred to as "Tammany Hall" and "the Aspen Institute." The bare knuckles realists of Tammany (such as White House Chief of Staff Rahm Emanuel) often won the most important debates, and the Aspen idealists often spent more time than they would have wished nursing their political wounds.

The author goes into extensive and sometimes painful detail about the debates among administration national security officials, attorneys, and other senior bureaucrats. According to Klaidman, "By the midway point of Obama's first year in office the White House's thermostat had swung toward Tammany." Rahm Emanuel is portrayed as tough and "transactional," focusing heavily on how any action could help the president's agenda without worrying about liberal ideals that were politically costly. Attorney General Eric Holder was often his chief foil and at least on one occasion was pushed to the brink of resignation. While Holder is one of Obama's closest friends, the president still tended to side with Emanuel on most important arguments in the belief that pragmatism was necessary to move the country forward. After over a year in office, Holder ultimately chose not to resign because it would have been widely assumed that he had been driven out by Tammany or become disillusioned with the administration to the point that he could no longer serve it. Holder understood the situation and remained a loyalist.

If the president needed any additional push to implement toughminded policies, he clearly received it when on 25 December 2009 a member of the terrorist group al Qaeda in the Arabian Peninsula (AQAP) barely failed in his mission to destroy a commercial US aircraft with 289 passengers. The consequences of such an action would have been catastrophic for both the country and the administration. In addition, due to an appalling death toll, the attack could have produced serious political pressure to do something dramatic in retaliation and perhaps even undertake some sort of intervention in Yemen, which could have gone very badly. In meetings with his senior national security officials, 
President Obama stated, "We dodged a bullet, but just barely. It [the attack] was averted by brave individuals [passengers], not because the system worked." Five months later, the Obama administration was lucky again when the "Times Square bomber," Faisal Shahzad, selected the wrong type of fertilizer for use in a car bomb and was arrested after his car smoked but did not explode. This incident was a second "dodged bullet" that influenced the security versus privacy/civil liberties debate in the administration. Under these circumstances, improving intelligence and security operations appeared increasingly vital if the United States was going to avoid a catastrophe. After the Christmas bombing attempt, Holder told his staff the increased danger of large-scale terrorist strikes had fundamentally changed the administration debate and they were now in a "new world." The Times Square bombing attempt only confirmed this assessment. Aspen increasingly started to look like Tammany.

A central part of the administration's response to terrorist near misses involved what the author calls "Barack Obama's ferocious campaign of targeted killings" through the use of armed drones. While some administration officials were uncomfortable with the legality of drone strikes, Obama was prepared to escalate their use to end the terrorist career of Anwar al Awlaki and other individuals like him. Awlaki was the Yemen-based planner of the Christmas Day plot, whom Obama designated as the leading terrorist target for elimination, having priority even over al Qaeda leader Ayman al Zawahiri. Unsurprisingly, Awlaki was subsequently killed in a US drone strike, despite his status as a US citizen. Also, as is well known, the Obama administration continued to make extensive use of armed drones, which Klaidman describes as a "seductive tool." In this political environment, some administration officials worried that capturing terrorists (who could possess valuable intelligence) was no longer a priority when they could be killed so easily. Yet, if President Obama remained a committed supporter of drone strikes, one hard-line policy he did not support was the continued use of the Guantanamo Bay prison to hold terrorism suspects. Rather, he had hoped to transfer these detainees to Supermax prisons such as the ones in Marion, Illinois, and Florence, Colorado, but was repeatedly and effectively thwarted by bipartisan Congressional objections.

In sum, this book is a particularly valuable resource since many of the issues it discusses provide important historical context for contemporary policy debates. These controversies include the arguments about privacy versus security involving the National Security Agency's activities. Civil libertarians who maintain the scales have been tipped too far in the direction of security can usefully consider the very close calls with terrorism mentioned in this study, and what kind of political environment would exist if they had succeeded. Likewise, individuals on all sides of the Guantanamo debate will have the opportunity to consider how indescribably difficult politically it will be to close that prison in any near-term time frame despite potentially viable alternatives. The issue of drones has also continued to be with us and is likely to remain the seductive tool for not only Obama but also many future presidents. 


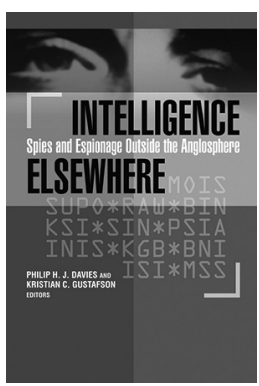

Washington, DC: Georgetown University Press, 2013

320 pages $\$ 34.95$

\section{Intelligence Elsewhere: Spies and Espionage Outside the Anglosphere}

\author{
Edited by Philip H. J. Davies and Kristian C. Gustafson
}

Reviewed by LTC Joseph Becker, Faculty Member at the National Intelligence University, Washington, DC

ultural analysis is an academic tool that holds considerable potential for understanding complicated issues outside an analyst's normal frame of reference. However, within the intelligence community, this tool is often misunderstood or misapplied, producing disappointing results that tend to discredit the discipline as a component in the production of quality intelligence analysis. The authors and editors of Intelligence Elsewhere: Spies and Espionage Outside the Anglosphere provide a different view. They claim that cultural analysis is beneficial and possibly vital to understanding both allies and adversaries. They build their argument by using comparative analysis to examine case studies written by multiple authors about a wide selection of intelligence services from non-Western countries. This book serves as both an example of how cultural analysis might be applied by practitioners of intelligence as well as an insightful collection of case studies about intelligence services that have often been neglected in the body of Western intelligence research.

This book devotes four early chapters to examining ancient intelligence traditions arising from China, the Maurya Empire in India, the Byzantine Empire, and the foundation of Islam. The authors and editors believe these traditions have a profound, but often unrecognized, impact on a swath of modern states and their security services. The book continues to describe individual countries and their security apparatus in terms of historical layers, each of which contributes a portion to the explanation of their organization's current status. As asserted by multiple authors throughout the text, the study of culture cannot predict what action a country or its leaders will take in any given circumstance, but it can offer great insight into how they will carry it out. Furthermore, even the individual actors themselves may not be fully aware of the influences that color their own decisionmaking processes.

The chapter on Russian security services, entitled "Protecting the New Rome," is a high point in the book. Russia's tilt away from the West since the end of the Soviet Union towards an authoritarian model has tended to baffle many Western observers. However, an examination of Russia's Byzantine influences provides a fascinating perspective on the culture that underlies this process. President Putin's patriarchal behavior toward the Russian Orthodox Church draws parallels to emperors of a millennium past, but far from being an isolated anachronism, this chapter demonstrates elements of this pattern have perpetuated, even during the Soviet Union. This culminates today in a security culture that has allowed Russia's intelligence services to weather extreme political change with surprisingly little impact.

Also of note, the authors of this work provide illuminating insight into the security services of both Iran and Japan. In the case of Iran, the chapter describes a "shatterbelt" of competing tensions, both internal and external to the current Iranian regime. This leaves Iran's intelligence 
services in a position of crucial importance, while tying their hands so that none individually can threaten the political status quo. A combination of Islamic and Persian cultural influences defines an intelligence culture designed to protect a government whose very foundations seem to define the word "paradox." Japanese culture, on the other hand, would seem straightforward by comparison. However, a number of cultural biases continue to relegate the field of intelligence to a secondclass status in Japan. Furthermore, the traditional value placed upon the attainment of consensus in every major decision means that even the best intelligence information might be brushed aside once agreement has been reached on a course of action or policy.

For countries with freely and democratically elected governments, the authors use the term "democratization of intelligence" as a basis by which to compare and contrast the progress that certain intelligence services are making in their evolution toward supporting the institutions of democracy and accountable governance in those countries. In several cases, authors trace a given country's political evolution side-byside with its primary security services. It is interesting to note, as in the case of Argentina, that in spite of major political changes, elements of a country's intelligence apparatus often have tremendous staying power and seem to run much deeper than the roots of any given organization or personality. This book demonstrates that intelligence culture is a product of history and changes to a given culture take considerable time.

Although Intelligence Elsewhere is written by a group of authors, the style is academic throughout. It is well-sourced and precise in its assertions. Cultural analysis is a broad field of study encompassing a number of variables and a tendency toward ambiguity. Therefore, in order to scope their arguments, the authors have loaded some portions of the book with qualifications and nuanced deliberations, which can make for cumbersome reading, especially for the casual reader. However, for students and practitioners of intelligence, this will be a valuable addition to their collection. It is also worth mentioning that many of these case studies could stand alone as primers or reference material on individual countries and intelligence services.

\section{Constructing Cassandra: Reframing Intelligence Failure at the CIA, 1947-2001 By Milo Jones and Philippe Silberzahn}

Reviewed by Mr. Ross W. Clark, Graduate Student, School of International Affairs, Pennsylvania State University

\footnotetext{
he Central Intelligence Agency's (CIA) shroud of secrecy allows for its effectiveness in addressing the nation's security problems. On 22 September 1947, President Harry Truman created the CIA under the auspices of the National Security Act of 1947. Under this act, the CIA's primary goal was and remains not only to evaluate intelligence related to US national security but also prevent strategic surprises that threaten US national security. The CIA's occasional intelligence failures and the potential reasons behind these inabilities are the topic of this book.
}

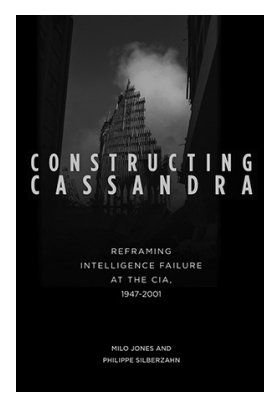

Stanford, CA: Stanford University Press, 2013 375 pages $\$ 53.18$ 
Constructing Cassandra, by Milo Jones and Philippe Silberzahn, discusses the failures of the CIA, including those associated with-the Iranian revolution, the collapse of the Union of Soviet Socialist Republics, the Cuban Missile Crisis, and the terrorist attacks of 9/11. However, in discussing these failures, it does not diminish the difficulty of the tasks at hand for CIA analysts and operatives. In this approach, the book clarifies the difference in opinions of the phrase "strategic surprise." Constructing Cassandra defines "strategic surprise" as "the sudden realization that one has been operating on the basis of an erroneous threat assessment that results in a failure to anticipate a grave threat to 'vital' national interests." Explaining the challenges of strategic surprises, challenging the Cassandras (individuals who anticipated the course of events but were ignored), and proposing recommendations are the main points of this study.

The culture and identity of an organization determine how it reacts to the environment and what problems it notices and addresses. CIA personnel's threat perception and ability to decipher threats from intelligence reports is dependent on CIA structure and organizational culture which, therefore, need to be studied. This approach, called social constructivist, is the process used to examine the social setting of the organization and how it affects its ability to do its job originally established by the National Security Act. Throughout the work, multiple persistent features of the nature of the CIA are outlined, including but not limited to the homogeneity of the personnel, preference of secret over open source information, and the idea of a consensus-driven atmosphere. Until recently, upper-class White Anglo-Saxon Protestant (WASP) Americans dominated the CIA as a distorted protective mechanism against betrayal. In addition, there is a preference for only clandestinely obtained information and a belief that its reliability is guaranteed by the secret manner in which this information is obtained. Finally, there is a widespread view that the CIA is a consensus-driven organization and there are social and institutional pressures not to be an analytical outlier. One CIA veteran, Robert George, states, "Trying to argue against the current analytical line can be seen as undermining teamwork or even a sign of personal self-promotion." What the above points do not describe in detail is how this identity is maintained and in what ways these aspects impact the decisionmaking process CIA analysts perform.

The selection process these analysts must endure speaks to the nature of the work CIA employees must complete. Personnel selection is important because of the intelligence profession and how the CIA trains analysts to gather data. The adaptation of the analysts to the CIA and their training processes play large roles in the socialization of that analyst. Constructing Cassandra reveals that no matter how good an individual's starting qualifications, the on-the-job training by their colleagues and superiors usher in unexamined social practices, analytical methodologies, and cultural norms. A suggestion the book offers is that along with analysts, the CIA needs intelligence "synthesists" to evaluate the analytical approach and it is this failure that leads to a misdiagnosis of some analytical problems. Other fundamental failures that may lead to strategic surprises include the widespread cultural norm that the CIA often attempts to satisfy its bureaucratic superiors as opposed to producing superior analysis, and that compartmentalization makes it hard to 
connect the dots in intelligence work. The failures examined throughout the book do not point to a single fault in the social mechanisms of the CIA or to the cultural norms instilled in its analysts; it rather states that the failures are products of a plethora of different aspects that make the CIA the entity it is today.

In conclusion, the book examines the future of intelligence gathering and analysis. It describes the need for a change in the intelligence cycle by establishing a hypothesis, followed by tasking, collection, analysis, production, and dissemination. Constructing Cassandra states that adding an hypothesis to the cycle will interject intellect and creative thinking into a process that often becomes too bureaucratic, and would assist the agency when its consumers demand answers. Jones and Silberzahn have crafted an insightful masterpiece to frame the true nature of the CIA. The depth to which their arguments are presented clearly shows the dangers a tight knit intelligence society may have when analyzing intelligence reports. Their purpose is not to craft lofty goals the agency will never reach but rather to examine the reasons why the agency failed in the past. I recommend this book to anyone with a passion in understanding the analytical framework of the CIA and who seeks to comprehend the theoretical approach, through the uses of organizational theory, in uncovering its internal mysteries. 


\section{Strategic LeAdership In Wartime}

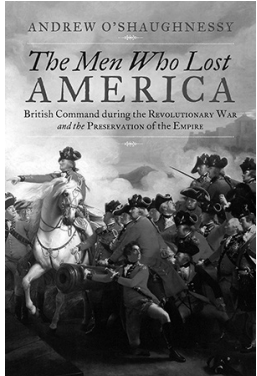

New Haven, CT: Yale University Press, 2013 466 pages $\$ 30.00$

\section{The Men Who Lost America: British Leadership, the American Revolution, and the Fate of the Empire By Andrew Jackson O'Shaughnessy}

Reviewed by Dr. James D. Scudieri, Department of Military Strategy, Plans, and Operations, US Army War College

his work provides a welcome reappraisal of the British loss of their American colonies, i.e., the American Revolution during 1775-83, in the context of British global strategic decisionmaking. The subject is not new. Author Andrew Jackson O'Shaughnessy credits Piers Mackesy, The War for America, 1775-1783 (1964, reprinted 1992), on the first page of the Acknowledgment, highlighting Mackesy's belief that the war was winnable but was lost to poor generalship, among other things. O'Shaughnessy states clearly that American victory was not inevitable. It is a somewhat harder task to challenge the conventional wisdom that the British loss was due to "incompetence and mediocre leadership," both political and military. The author packages the monograph in nine biographical chapters, examining ten British leaders at policy, strategic, and theater strategic/operational levels, in sequence: King George III; Lord North as prime minister; the Howe brothers, Admiral Lord Richard and Lieutenant General Sir William; Major General John Burgoyne; Lord George Germain, Secretary of State for the Colonies, a third Secretary of State created in 1768; Lieutenant General Sir Henry Clinton; Major General Charles, 1st Marquis Cornwallis; Admiral Sir George Rodney; and John Montague, Earl of Sandwich, as First Lord of the Admiralty.

The work features senior leaders wrestling with an unprecedented set of problems, in the author's words "obstacles of such magnitude." $\mathrm{He}$ explains their decisionmaking in the overall context of the eighteenth century; the nature of the English state, extant political institutions, and their processes; global strategy; and ultimately the nature of the military element of power, land and naval. For example, despite the previously showcased ministry of Sir Robert Walpole in British history, O'Shaughnessy underlines the as-yet evolutionary nature of English government at the time, especially the gradual development of true cabinet government with collective ministerial responsibility. His interpretation is not without controversy, at least insofar as extant practice to ensure political survival resulted in conduct for collective shielding.

He believes the "most fundamental miscalculation" of these senior leaders was the belief that Loyalists constituted a majority of the population in America. Moreover, these same leaders did not understand the changes that took place in the war's nature. Its length, seeming without end, increased popular antipathy toward British military presence. Significantly, O'Shaughnessy cites the Declaration of Independence as a seminal document for genuine, revolutionary change: a radical republican creed which beckoned a better future.

Furthermore, in current terms, he sees a serious imbalance in ends, ways, and means. He highlights the major aspects of the post-war drawdown after 1748, following the end of the War of Austrian Succession. 
He concludes that both the Royal Navy and British Army were too small for the task at hand. The latter simply lacked the strength to conquer and occupy the American colonies, especially given the alacrity with which Patriot forces had taken control of established institutions, further underlining Loyalist weaknesses.

Multiple demands upon military power exacerbated this imbalance. O'Shaughnessy repeatedly reminds readers to comprehend Britain's global responsibilities. War against the thirteen American colonies occurred with simultaneous concerns for Canada, the Caribbean, India, and Europe itself. These other theaters became ones of pressing urgency with French and others' active intervention in the war from 1778.

The author's analysis of the daunting logistical challenges to wage global warfare during this period could stand as a case study in its own right. He summarizes and synthesizes a considerable body of primary evidence and historical examinations. The reality that the British Army in America could not sustain itself in theater came as a shock, and drove major aspects of planning.

The dissection of such political and military decisions also accounts for the human domain. His ten main characters are not distant eighteenthcentury aristocrats. They are individuals with strengths and weaknesses, and families upon whom they depended and who mattered greatly in their lives. He also shows how personalities mattered in the daily workings of governmental business and English society at large, including an explanation of the nature and role of the media in eighteenth-century England. He reviews the vocal, politically astute opposition to the war in England. Moreover, he hints at English leaders' ambivalence on how to fight this war, typified by the Howe brothers and the Peace Commission. Few today, on either side of the Atlantic, appreciate how such diffidence became official confusion. America was in revolt, but somehow the situation was not the same as previous experience dealing with Ireland and Scotland. Perhaps the best manifestation of this doubt concerns the British Army. It never obtained battle honors for any victories in the course of the American War against the colonists.

O'Shaughnessy's book does mirror earlier works in several ways. Besides Mackesy (already cited), Jeremy Black, War for America: The Fight for Independence, 1775-1783 (1991) also asserted that American victory was not inevitable. In other words, there are cogent explanations why the Revolution could have failed, or conversely, the British could have won. Yet O'Shaughnessy's core thesis is well beyond the question whether the war was winnable. Herein is the freshness of the work.

O'Shaughnessy does not rest with the mere assertion the British could have won. Indeed, he concludes conditions generally were not favorable for British victory. However, he categorically denies the stereotype of British political and military incompetence, in stark contrast to William Seymour and W. F. N. Watson, The Price of Folly: British Blunders in the War of American Independence (1995). Indeed, he asserts chronic perceptions of incompetence have clouded how close and how often the outcome was in doubt. Moreover, his methodology is of particular interest to this readership.

His analysis of leaders at multiple levels, from the British king to senior commanders in the field, is a masterful case study in both vertical 


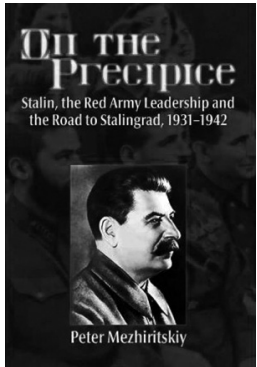

England: Helion \& Company, 2012

399 pages

$\$ 59.95$ and horizontal integration. The author delivers an early pledge to shatter "old shibboleths" in both the United States and the United Kingdom, as well as to challenge cherished aspects of American, national mythology. The specialist will find a few, minor errors. Regardless, this work stands as a major contribution with its phenomenal balance of primary and secondary sources and depth of synthesis across a staggering wealth of historiography on the American Revolution from the perspective of the subjects.

The Men Who Lost America is an important book. It dissects the seniorlevel "sausage making" of the British effort to reassert control over its wayward colonies. It provides a case study of especial resonance today. It showcases the misunderstanding inherent in stereotypical and simplistic explanations. Moreover, it does so in terms of special relevance to the readership of Parameters.

\section{On the Precipice: Stalin, the Red Army Leadership and the Road to Stalingrad, 1931-1942 By Peter Mezhiritsky}

Reviewed by Dr. Stephen Blank, Strategic Studies Institute, US Army War College, American Foreign Policy Council

here is a compelling need for a systematic study of the topic outlined in the title, especially as so much more has been learned about Stalin and the Red Army since the collapse of the Soviet Union. Unfortunately, this is not the book to fill that gap. Indeed, it represents a regression in our efforts to understand Stalin, the Red Army, and the Soviet system as a whole. In the last twenty years as some archives have been opened and Russian historians have enjoyed greater (though not full) freedom to publish about hitherto "closed" topics, we have learned a great deal about Stalin, his system, and the Red Army. Previously, and especially during the 1950s and 1960s, it was exceedingly difficult to obtain reliable information and evidence concerning these subjects. As a result, too much of the literature had to rely on what could fairly be described as rumor, hearsay, and - to be blunt - educated (or not so educated) conjecture. Fortunately, for the most part that is no longer the case.

Unfortunately the author of this book has reverted to the bad old days and this work is replete with the earlier form of source material and "evidence" instead of solid research backed by evidence. Page after page is replete with statements like "I was told by" or "X remembers that," etc. Moreover, the lack of evidence causes the author to fail to ask-let alone answer-fundamental questions. The reader is left with what is essentially a thoroughgoing demonization of Stalin. The issue here is not that Stalin deserves that demonization. That is beyond doubt. But why did his helpers all the way down the line assist him in decapitating the leadership of the Red Army? Why did the Generals mentioned here, who fell victim to the various purges and arrests, not rebel if they were such paragons of bravery and virtue as the author suggests? Indeed, why did the armed forces as a whole not revolt against collectivization, the purges, etc? Absent evidence, it is impossible to formulate answers to 
these questions, which are key issues for the study of the Red Army in Soviet affairs.

Despite the glossy production virtues of the book, these serious shortcomings invalidate it as a serious and useful account of the period under review and this is a great pity. Recent works by Roger Reese, David Glantz, David Stone, and others have shown the nature of the Red Army under Stalin, and the onset of the militarization of the Soviet economy as a whole. But since the pioneering work of John Erickson, which stands alone despite having been composed over fifty years ago when evidence was scarce, we have not had a systematic analysis of the Soviet High Command to use Erickson's title. Without such an analysis, it really is impossible to answer the questions posed above and others that may be of important analytical value for historians and students of the Red Army. If we take into account the centrality of the army as an institution to both Tsarist and Soviet rulers alike as well as the militarization of the Soviet economy, described by Oskar Lange as a Sui Generis war economy, we cannot understand either Stalin or the system in their totality.

Of course, in the absence of such an analysis, it would be virtually impossible to determine what expectations Moscow actually had during the thirties of the imminence of a European war, whether it would involve Russia and, if so, under what circumstances. Neither is it possible to guess at, let alone analyze, Soviet war aims without such an evidentiary and analytical foundation. Inasmuch as the Cold War, and possibly Operation Barbarossa, were triggered by Stalin's efforts to realize his war aims, these are not purely academic questions. Unfortunately for the serious reader looking for evidence or answers to these questions, those things are not found here. And that is everyone's loss.

\section{The Swamp Fox: Lessons in Leadership from the Partisan Campaigns of Francis Marion \\ By Scott D. Aiken}

Reviewed by Jill Sargent Russell, Doctoral Candidate in War Studies, King's College London

ne approaches works on military leaders written by their lifelong fans with a sense of dread. Often, these works cannot escape the bounds of hero worship to provide commentary more useful than laudatory. Colonel Scott Aiken has managed to avoid the pitfalls of his inspiration on the way to crafting a really fine piece of scholarship on General Francis Marion's leadership and campaigns.

This is a work of two narratives. The first, and predominant one, covers the history of General Marion and his role commanding a partisan formation in the campaign to defeat the British in South Carolina. The second argues the relevance of this history to contemporary issues of war. Mastering the primary historical narrative, the work misses excellence for the relative weakness of its attention to the contemporary story. I am at pains to remind readers the critiques and issues brought out in this review are, in part, the result of how deeply engaged with the

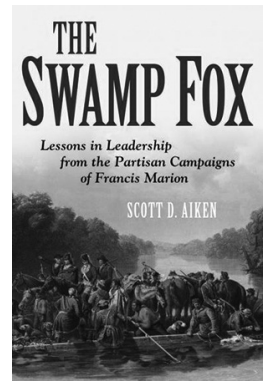

Annapolis: Naval Institute Press, 2012 384 pages $\$ 42.95$ 
narrative I felt; because it was interesting and challenging, it made me think.

This is not a book for novices to military affairs or the history of the American Revolution. The first is true because the military content is referenced according to technical and professional standards. The second is because the historical content is tightly concentrated in time, place, and type of activity. For the right audience, however, the work is valuable.

The book is dense and focused; anything more than a brief synopsis would exceed the bounds of this review. The primary argument of the work is that the strategic, tactical, and procedural choices made by Marion were successful and bear consideration in contemporary military practice. Taking a methodical approach to Marion's military career from the fall of Charleston in 1780 to the departure of the British from Charleston in December 1782, Aiken maintains attention upon this theme. Both independently and in support of the Continental Army under Generals Horatio Gates and Nathanael Greene, Marion is shown to make the best use of the skills and local knowledge of his irregulars against the enemy's critical and vulnerable points in South Carolina. The chapters provide detailed narrative, assessment and explication of the relevant concepts of military affairs while exploring the contours and content of Marion's campaign and his leadership and direction thereof, and could stand alone as independent case studies for classroom or research. Overall, it is well and interestingly written, relying on comprehensive sources and citations by way of endnotes.

One minor problem with the narrative concerns the role and relevance of the militias and partisan formations in the American Revolution. Within recent scholarship there is far greater scepticism regarding the utility of these forces than Aiken acknowledges. That is understandable given his argument relies on opinions attributing decisive importance to the militias and irregulars in that war. Furthermore, from the experience of Marion and his unit, there is certainly a case to be made for their unique value and effectiveness. However, whether this case can sustain a general assessment on the value of the military forces beyond the Continental Army is debatable. At minimum, the opinions of many senior leaders at the time regarding the reliability and costs of militias and irregular forces should have been a matter for Aiken's professional consideration. It would have been better to frame Marion's case as an outlier within the universe of the irregular forces in that war, as this would have made more impressive his military and leadership achievements.

Reminding readers that I think this is a very strong work and comfortably recommend it, I cannot ignore that the lurking contemporary narrative Aiken suggests, but has largely neglected, is the great flaw of the book. Although contemporary examples regularly appear, their use too often seems disjointed within the Marion narrative. In most of the chapters these nuggets of information appear as appended to the ends of paragraphs and sections, almost as if bolted on as an afterthought. This is a shame, because they are sound and thought provoking. It is simply the case that they are too often undeveloped, either in detail or analysis. The exception is in the second part, with the chapter on "Information Warfare," in which the author examines contemporary 
examples in detail. However, there is no explanation for this deviation from his practice in the other chapters, which leaves the reader at a bit of a loss. These are important comparatives, and they deserve the rigorous treatment the author applies to Marion's history.

A full chapter on the contemporary correlates is necessary because reading the narrative and taking into account the examples Aiken provided, one is irrevocably driven to certain conclusions. If it is critical to learn from the positive example of Francis Marion, then the British Army and Loyalist militias offer a negative lesson-what and how not to be. And, from the American perspective, one must then ask in whose image we have fought the last ten years. Or, concerning the tactics and operations of the enemy, nothing which has confronted American and allied forces in Iraq or Afghanistan should surprise. The means and targets of the insurgency, the use of the weight of our own operations and logistics against American forces, have been predictable and sensible according to the Marion narrative. Do we need to respect the enemy in Iraq, Afghanistan, and elsewhere more? Can we ever expect to win? And these questions don't even touch on the Vietnam example.

The problem is not that these issues must be proven. There is a deeper and more serious relevance to the history of Francis Marion, partisan genius. Rather, one sincerely wants to see the book completed, the entire narrative delivered, and particularly how Aiken would deal with the correlations to contemporary experience. Given that they run contrary to so much of the conventional and comfortable wisdom on the subjects, it would be useful for an author of his background, an infantry officer and veteran, to put these thoughts to a wider audience. Like Nixon in China, one needs a trusted figure to offer the radical as reasonable. 
New Perspectives on Vietnam

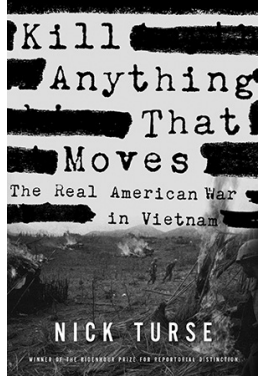

New York: Metropolitan Books, 2013

370 pages

$\$ 30.00$

\section{Kill Anything That Moves: The Real American War in Vietnam}

\author{
By Nick Turse
}

Reviewed by William Thomas Allison, PhD, Gen. Harold K. Johnson Visiting Chair in Military History, US Army War College

nvestigative journalist Nick Turse offers a disturbing account of American atrocities in the Vietnam War in a commendable attempt to bring attention to the death and destruction wrought upon South Vietnamese civilians. His purpose is to expose "the scale of civilian suffering" in Vietnam, while claiming that American "command policies"-free-fire zones, body counts, search-and-destroy missions, and the use of excessively destructive conventional technology-established a deadly but accepted standard of "overkill" at the operational level. At the tactical level, this "overkill" created a caustic atmosphere among US forces, one that encouraged American troops to commit atrocities-rape, mutilation, murder, mass killings — with callous impunity. This is a very grim and chilling read indeed.

Turse bases his findings on his examination of the US Army's Vietnam War Crimes Working Group collection in the National Archives. Collected by a then-secret group in the wake of the My Lai investigations, these records detail approximately 800 alleged and investigated incidents and cover-ups of atrocities committed by American military personnel. They range in scale from barbarous individual acts to the body-count mayhem orchestrated by the "Butcher of the Delta," Major General Julian Ewell, who with his 9th Division conducted a multi-month mass killing spree called Operation Speedy Express in the Mekong Delta during 1968. Turse takes the reader through example after example of soldiers raping young girls in rural villages, intentionally running down children with deuce-and-a-half trucks, and shooting unarmed civilians, among other incidents. He supplements this material with extensive interviews of veterans and Vietnamese victims; these may be Turse's greatest contribution and are a credit to his journalistic skills.

A harsh critic might suggest Turse cherry-picked his evidence; a more generous reviewer would criticize his data sample as too narrow. Absent is context beyond what fits Turse's agenda. He ignores the very compelling stories of servicemembers who honorably performed their difficult duties, despite the dark character of the war in which they fought. He overlooks civic-action programs, the broader pacification strategy, and other nonmilitary efforts that, flawed as they were, worked alongside military operations in what was obviously a failed and tragically costly effort to stabilize South Vietnam. Missing is a balanced examination of the impact of atrocity allegations on the antiwar movement and the frustrating difficulty of prosecuting atrocities under the Uniform Code of Military Justice. To bring attention to civilian suffering would also warrant examination of Viet Cong atrocities committed against Vietnamese noncombatants - this, too, is absent.

The author also ignores the commonality of civilian suffering in all war. For example, did not the way in which American forces fought 
World War II contribute to atrocities in Europe and the Pacific? Rape committed by American forces in France, for example, occurred just as it did in Vietnam (see J. Roberts Lilly, Taken By Force: Rape and American GIs in Europe during World War II, from Palgrave Macmillan, 2007). Turse quotes at length from Michael Herr's seminal book Dispatches (Knopf, 1977), citing the macabre photographs taken by GIs in Vietnam-posing with severed heads, showing off necklaces of severed ears, and dragging corpses unceremoniously behind various vehicles. Such acts, vile as they are, are not unique to Vietnam. Has not YouTube alone provided numerous examples of the same from Iraq? Afghanistan? This is a missed opportunity. The same argument the author applies to Vietnam could easily apply elsewhere, but viewing Vietnam, or any conflict, through this one lens dramatically skews the broader picture.

This is not to excuse or condone atrocities with Sherman's epithet "war is hell." But, war is hell, and atrocities occur despite diligent preventive efforts. Turse is certainly correct in that the way a war is fought can affect the occurrence of atrocities. History is replete with examples. While the author should be applauded for taking on such a grim and challenging subject, for exhaustive though narrow research, and for bringing attention to the immense suffering of the Vietnamese people during this awful war, he offers little that has not been previously discussed, suggested, or argued. No serious historian of the Vietnam War disputes that the way American forces fought the war contributed to an atmosphere of atrocity. None doubt that command at all levels may have swept allegations under the rug or that incidents went unreported. Few historians argue that My Lai, while an aberration in scale, was an aberration in practice. Historians focus on My Lai because it is symptomatic of the wider issues that Turse attempts to address. To claim they do so at the expense of the broader suffering of combatants and noncombatants, however, is off the mark.

The author states the "indiscriminate killing of South Vietnamese noncombatants ... was neither accidental nor unforeseeable." This implies that American political leaders and military commanders wantonly pursued a war of mass indiscriminate killing. Turse does not convince that this was indeed the case. That needless deaths and wounding of hundreds of thousands of civilians, however, was the consequence of the way the United States fought the war has long been the consensus among historians.

The book's singular value lies in its brutal content. Turse does remind us of the extreme character and tragedy of atrocity. In the end, however, he offers an uneven view of a controversial war. 


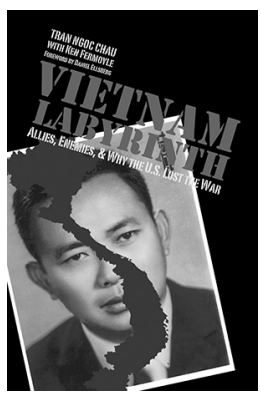

Lubbock: Texas Tech University Press, 2012 480 pages $\$ 39.95$

\section{Vietnam Labyrinth: Allies, Enemies, and Why the US Lost the War} By Tran Ngoc Chau, with Ken Fermoyle

Reviewed by Dr. William Thomas Allison, Harold K. Johnson Visiting Chair in Military History, US Army War College

xciting new scholarship on Vietnam continues to expand our understanding of this divisive war. Scholars now apply multidisciplinary approaches to archival sources in Vietnamese, French, and English, revealing fresh, provocative perspectives, and new voices, to give the historiographic box of Vietnam a much-needed shake. Recent Vietnamese memoirs contribute significantly to this welcome trend.

Tran Ngoc Chau's Vietnam Labyrinth, is one such memoir. Chau's story is compellingly captivating and valuable. Rare is the story told of a Vietnamese soldier who in 1946 served with the Viet Minh against the French, changed sides in 1950, then became a key member of the South Vietnamese government, was imprisoned by that same government in 1970, then was imprisoned again by the North Vietnamese in 1975, then escaped to the United States in 1979. His story reveals much about loyalty and betrayal, service and sacrifice, hope and disillusionment, and perceptions and misunderstanding, among the Vietnamese, the French, the Americans, and even Chau himself. His is a truly distinctive lens through which to examine the thirty-year Vietnamese struggle for independence.

As a young man in September 1945, Chau rejoiced along with millions of his countrymen when Ho Chi Minh declared Vietnam's independence, but Chau did so as a nationalist, not a communist. Chau subsequently joined the Viet Minh, perceived by many in Vietnam at the time to be more nationalist than communist in its fight against France. An excellent officer and combat leader, Chau soon gained the attention of influential officers and political officials as he rose through the ranks. By 1950, however, Chau had become disillusioned with his comrades, as communist dogma resourcefully supplanted nationalism as the principal guiding force behind the Viet Minh. Ho's government conducted several mini-purges of nonbelievers while recruiting experienced and skilled leaders like Chau into the Vietnamese Communist Party. Born to a traditional Buddhist mandarin family with distant but deeply-held dynastic ties, Chau could not reconcile his love of country with his fear of what communism would mean for Vietnam. Thus, he made the difficult and dangerous decision to change sides.

It took time for Chau to prove his loyalty, but through courage, skill, leadership, and some well-placed guardian angels, he overcame his understandable doubters. Chau again quickly moved up the military/political chain-lieutenant colonel, province chief of Kien Hoa, mayor of Danang, representative in the National Assembly, and ultimately Secretary General of the National Assembly. Through his own evolution as a Vietnamese patriot, he experienced the unfolding wars for Vietnam's independence-first the French Indochina War, then the American War in Vietnam, conflicts that fused a war for independence, a civil war, a war of unification, and a Cold War-proxy war into one 
confusing tragic conflict. Along the way, he formed close associations with Americans John Paul Vann (who claimed Chau knew more about defeating a communist insurgency than anyone in Vietnam) and Daniel Ellsberg (who wrote the foreword for Vietnam Labyrinth), among others. He was a military academy classmate of Nguyen Van Thieu, who in 1970 as president of South Vietnam had Chau unconstitutionally imprisoned and held in solitary confinement for almost four years for "advocating democratization of the South and political negotiation with the North."

Chau's memoir provides insight into the inner workings of the Viet Minh, the South Vietnamese government, and the French, then American, presence in South Vietnam. He gives powerful testimony to the trauma of thirty years of war on a small nation caught in the destructive vise between internal struggles and great power conflict. Chau's most significant contribution, however, derives from his close work with American military and civilian personnel in South Vietnam. He witnessed their faulty perceptions, lack of understanding, and cultural arrogance that in his assessment undermined South Vietnam's chances for independence. The preponderance of the American presence, the cultural illiteracy of American advisors and officials, the misplaced American backing of reactionary Vietnamese in high government positions, and the overuse of massive firepower while neglecting basic pacification principles fed South Vietnamese dependence upon the United States, undercut government legitimacy at all levels, and alienated the population.

While these conclusions are neither novel nor new, the context in which Chau presents them is original and insightful. His memoir, like Nguyen Công Luan's Nationalist in the Vietnam Wars: Memoirs of a Victim Turned Soldier (Indiana 2012), is invaluable to moving beyond an American-centric history of the Vietnam War. Defense professionals should read history, and they should read Vietnam Labyrinth to understand the "other" in American wars, be they ally or enemy.

\section{Losing Vietnam: How America Abandoned Southeast Asia By Ira A. Hunt, Jr.}

Reviewed by Dr. David Fitzgerald, School of History, University College Cork, Ireland

ver forty years after the signing of the Paris peace accords, the "postwar war" in Vietnam continues to be relatively neglected, at least by the standards of the literature of that exhaustively documented conflict. With Losing Vietnam: How America Abandoned Southeast Asia, Ira Hunt adds to the literature by offering an analysis of the collapse of South Vietnam and the Khmer Republic and strives to correct misperceptions about the denouement of the war; instead, he accidentally offers a window into the

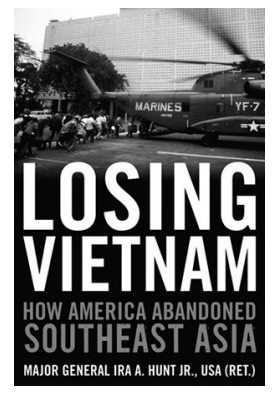
Lexington: University Press of Kentucky, 2013 mindset that contributed to America's defeat in Indochina.

Part of the Association of the US Army's "Battles and Campaigns" series, the book uneasily straddles the line between analysis and memoir. Hunt (who also served as Chief of Staff in the 9th Infantry Division in Vietnam from 1968 to 1969) certainly had a unique vantage point on this period of the war. As Deputy Commander of the United States Support 
Activities Group (USSAG) in Thailand during this period, Hunt met frequently with senior military leaders of South Vietnam and Cambodia and had access to all Southeast Asia operational reports. He uses that perspective to produce an account of the efforts of various US military advisors and diplomats to keep American financial aid flowing into Indochina. The title of the book is something of a misnomer, as only half the book covers the final years of the Republic of South Vietnam, while the rest focuses on the war in Cambodia, with some brief codas on the Mayaguez incident, the insurgency in Thailand, and the war in Laos.

Throughout, Hunt argues the lack of US funding for the South Vietnamese and Cambodian war efforts doomed both governments to defeat. Hunt produces table after table highlighting the curtailment of ammunition expenditure and the drop in flying hours that meant the South Vietnamese and Cambodians were unable to hold off the final communist onslaughts in the spring of 1975 . He argues ammunition shortages and rampant inflation created deep-seated morale problems in South Vietnamese and Cambodian forces. Somewhat tendentiously, he claims, despite all of this, "in early March 1975 South Vietnam was holding its own," making a similar claim with respect to the Cambodians. Hunt is more willing to blame the institutional culture of the Cambodian Army than he is to seriously question the decisionmaking of the Republic of Vietnam Armed Forces (RVNAF) leadership.

Hunt's argument is thoroughly informed by his Thailand-based perspective. In many ways, this book is a distillation of various reports that crossed Hunt's desk in Nakhon Phanom airbase. While he produces statistics for things as diverse as ammunition expenditures, precipitation in Indochina, enemy-initiated incidents, and a "won-lost" ledger for major engagements in South Vietnam in 1973 and 1974, there is something missing here. These data capture much about the war. The tables and figures enrich our understanding but not as much as the author might want us to believe. By focusing so much on the data flowing into United States Support Activities Group headquarters, Hunt completely ignores South Vietnamese or Cambodian perspectives, despite the fact that they, not the Americans, were the war's chief protagonists at this time.

For instance, the author does good work in showing the impact of reduced US funding on ammunition supply and expenditure in South Vietnam, but we learn nothing about the origins of President Thieu's "four no's" decision, which committed RVNAF to a static defense of its territory and was a major factor in the South Vietnamese defeat (something even Hunt, who is eager to highlight American culpability for the fall of Saigon, admits). Nowhere in the book is there a detailed analysis of the culture of the Army of the Republic of Vietnam leadership or of the Government of Vietnam corruption. Reading Hunt's account of the final collapse of South Vietnam, this reviewer was reminded of Arnold Isaacs' point that 'to acknowledge that South Vietnam's collapse had moral and not just material causes was painful [because it] . . . meant there was no American remedy for Vietnam's defeat."

While part of this reliance on statistics and focus on material can be ascribed to where Hunt sat during the events he describes, much of this is a symptom of his general view of the uses of data and statistical analysis, which are always privileged over more qualitative assessments of South Vietnamese performance. The narrowness of the perspective 
Hunt adopts means that those interested in the last years of the wars in Vietnam and Cambodia would be advised to turn elsewhere for more comprehensive analysis. For a complete picture, scholars would do better to read James Wilbanks' Abandoning Vietnam: How America Left and South Vietnam Lost Its War (University Press of Kansas 2004) or even Arnold Isaacs' classic journalistic account of the fall of South Vietnam and Cambodia, Without Honor: Defeat in Vietnam and Cambodia (Johns Hopkins University Press 1998). Hunt's book is still useful on two levels - as a semi-autobiographical account of the Vietnam War's final years and as an example of the quantitative-driven worldview that permeated American leadership throughout the Vietnam era. The author's attempts to quantify South Vietnamese and Cambodian battlefield performance through win-loss and combat initiation ratios are efforts of which Robert McNamara would have been proud.

In Gregory Daddis's excellent work on the use of metrics in the American war in Vietnam, he pointed out the extent to which a datacentric approach informed US thinking on the war and concluded that "in short, there is more to winning than counting." Surely the same applies to losing. 


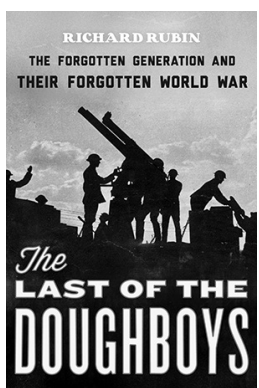

New York: Houghton Mifflin Harcourt, 2013 528 pages $\$ 28.00$

\section{ReVISITING the GREAT War}

\section{The Last of the Doughboys: The Forgotten Generation and Their Forgotten World War}

\section{By Richard Rubin}

Reviewed by Dr. Michael S. Neiberg, Professor of History, Department of National Security Studies, US Army War College

ichard Rubin travelled around the United States at the beginning of this century to find some veterans of the most important event of the last century. He managed to find several surviving World War I veterans, all of them 100 years old or older. To his surprise, and our good fortune, most of them were more than willing to talk to him and had excellent long-term memories. Rubin has done us all a great service by getting their recollections on paper and recording them for posterity.

Their stories are nothing short of astonishing, offering glimpses into a world, and an America, before the great calamity of 1914. For some of these veterans, military service was a highlight of their lives, giving them a chance to see some of the world and to participate in the most important event of their generation; for others, military service was an interesting (and sometimes terrifying) interlude in a life that went on as normal once they returned to the United States. They kept some memories alive and suppressed others, sometimes for decades. Rubin gave them a chance to talk about those memories.

Some common themes emerge from Rubin's interviews. Few of his interviewees showed much interest in geopolitics, and almost all of them joined the military for the same reasons young men have throughout history: for adventure; for a vague sense of patriotic duty; or because their friends were doing the same and they did not want to be left behind. Virtually all of them use the word "lucky" or some synonym to explain why they survived while so many others did not, reminding us all of the random and capricious nature of war. They were for the most part modest men, many of whom had not spoken seriously about the war in decades.

Between chapters featuring interviews with veterans, Rubin has spliced chapters about the war itself. Some of this material introduces the big concepts of the war to a reader who might be unfamiliar with trench warfare, the Meuse-Argonne, and poison gas. Others deal with elements of American culture in 1917, including a chapter on the most popular songs of the time, another on the books Americans would have been reading about the war in Europe, and one on soldier memoirs. The chapter on music is his best; Rubin collects old music and thus knows the subject well. He has introduced a new generation to the wonderfullytitled Tin Pan Alley tune "If He Can Fight Like He Can Love, Good Night Germany!" It contained the lyric "If he's half as good in a trench/ as he was in the park on a bench ...." It wasn't such an age of innocence after all.

These chapters, however entertaining at times, break up the flow of the book and distract the reader from the book's core theme, the 
recollections of the veterans themselves. Rubin is not an historian, and his lack of knowledge about some key components of the war will be transparent to those who have studied the war in any depth. As a result, he repeats several old myths and stereotypes about the war. He also has a tendency to simplify very complex topics into one or two sentences. A greater attention to the actual history of the war would have smoothed off some of the rough edges of these digressions. He might also have chosen to drop most of these chapters altogether, keeping the focus where it belonged, on the veterans themselves.

Rubin, a journalist, writes in an informal style that some readers will find engaging and others will find distracting. One three-page stretch of the book features the word "I" no fewer than 33 times. Rubin aimed for a conversational tone, trying to bring the reader along with him into the living rooms, retirement homes, and hospitals where he interviewed these men (and two women). That choice may work for some, but it also distracts us from the people at the center of the book, the best-known of whom, Frank Buckles, was the last surviving American veteran of the war.

And those people are the real reason to read this book. We learn about the intense racism and segregation that marked not just the Army but American society in general. We also learn about the complex identities of so-called hyphenated Americans; the tensions experienced by Americans in this time of transition from a rural to an urban society; and the difficulties of getting the United States involved in the most terrible war the world had yet known. The veterans he talked to told stories of comrades, most likely suffering from post-traumatic stress, committing suicide after the war. He also notes a veteran who never cashed the check the Army gave him on separation. He would rather, he said, have had that check (for one dollar) as a souvenir.

If not for the work of Richard Rubin, these voices and the stories they told would have been lost forever. His book, therefore, performs an important service to all of those interested in World War I, the experience of soldiers at war, and the history of the United States in these years. The criticisms above do not in any way detract from the real value of the book, a chance to listen to men and women who lived through an extraordinary age.

\section{Winning and Losing on the Western Front: The British Third Army and the Defeat of Germany in 1918 By Jonathan Boff}

Reviewed by Dr. Dean A. Nowowiejski, COL (USA Retired), whose dissertation analyzed the performance of the American military governor of the Rhineland, MG Henry T. Allen, who commanded the 90th Division in the AEF before commanding American Forces in Germany during the occupation

onathan Boff takes the readers of Parameters into a different world in this book. Those who are American students of military history get to explore the British perspective. Those who have studied World War I receive a new argument that mines both British and German sources to

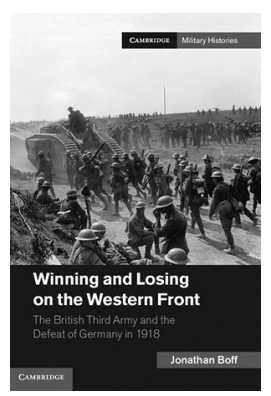

New York: Cambridge University Press, 2012 286 pages $\$ 99.00$ understand tactics, operational art, and an analysis of the outcome of 
the 100 Days Campaign in the late summer and autumn of 1918. Boff focuses on the hitherto largely unexplored British Third Army defeat of the German Seventeenth and Second Armies, a lens that allows him to use both statistical and cultural terms of analysis. His developed story is complex, but convincing. Jonathan Boff demonstrates mastery of both English and German language sources, and his argument clearly addresses the historians who previously wrote about the British Army at the end of the Great War. In fact, one senses a mastery of the literature in his thorough presentation, and one of the advantages of his book is to connect to the British historiography of the war.

His level of tactical analysis resembles Mark Grotelueschen's insightful observations in The AEF Way of War: The American Army and Combat in World War I. Both accomplish detailed tactical examination through careful mining of the historical record. Jonathan Boff exhaustively analyzes available war diaries of both the British Third and the German Second and Seventeenth Armies to the Corps, Division, and sometimes Brigade level to understand the complexities of tactical result. His exploration of tactical detail also allows him to dissect the effects of battle on morale and reveal innovations in leadership at that level.

Winning and Losing on the Western Front addresses the four prevailing hypotheses (page 15) concerning the result of the "Hundred Days" campaign (from 8 August until the Armistice) and offers a clear conclusion concerning the validity of each one. The first is that the Germans were overwhelmed by superior numbers, both in men and materiel. Boff finds that the progressive attrition that took hold earlier in 1918 bore fruit in the Hundred Days campaign as the German Army became progressively less capable of defense in depth or effective counterattack, and its formations gradually disintegrated as they remained committed and the system of reserves broke down. The Germans also perceived they were at a materiel imbalance, particularly in tanks, and this weighed on their morale.

The second hypothesis: German Army morale collapsed. Boff adeptly reveals that this simply did not occur. The Germans may have suffered poor "mood" but not broken "spirit," a construct he develops in the lengthy chapter exploring morale in both Armies. Boff in fact claims that morale inside the German tactical formations was surprisingly resilient until just before the Armistice.

Third, the British by this point in the war were able to defeat the Germans because of superior tactical method. Here, Boff's analysis carefully takes apart the several factors involved in combined arms operations at this point in the war, and finds that elements such as the employment of tanks, aircraft, and signal were not all that effective for the British, that infantry and artillery cooperation accounted for the majority of instances of combined arms employment, and though this employment was more flawed than previously exposed, the British still exceeded the Germans in combined arms employment by this point in the war. But decline in German combined arms effectiveness accounted for much of the result, too.

Fourth, "British victory was the outcome of superior operational art." Boff finds here British operational command was far less flexible than previously revealed, and it was German failings in operational 
command that contributed more to the British success. The failings of the German Army are a surprise emphasis in Winning and Losing. The Germans, contrary to popular perception, did not practice "mission command" as we now know it; in fact, their flexible system of command deteriorated ever more severely as they stumbled toward the end of the war, and their operational commanders tried desperately to exert strong control on events, to little avail.

Boff's useful framework of analysis builds on these broad hypotheses, while recognizing some minor oversimplification and overlap in doing so. To achieve this result, the book explores the four hypotheses as outlined above, taking each in turn through sequential chapter level analysis. Boff begins with a summary of events then offers chapters on manpower and training, materiel, morale, and tactics for both sides. $\mathrm{He}$ winds up with operational analysis and a fine, concise conclusion. The use of a series of maps at the front as a common reference proves to be effective, and many of the photographs which dress the text are clear, interesting, and relevant.

Jonathan Boff's argument is sometimes subtle, often nuanced, and always squarely in the context of existing historiography. You know exactly where he stands on the historical hypotheses of existing literature. His method does not allow for a fast read, because the prose is densely packed with research and meaning, and he offers many significant findings in the course of this short book. For those who want a model of tactical, and particularly operational, battle analysis, Winning and Losing on the Western Front offers many valid techniques. His book will be most satisfying, not for the general reader, but for the expert in operational history, World War I battle, and in the character of leadership and of armies. Thus, his book is recommended for many readers of Parameters. 



\section{Article Index, Vol. 43, 2013}

Aftandilian, Gregory. "Pitfalls in Egypt.” Autumn 2013. pp. 17-28.

Bahgat, Gawdat. "The Iranian Nuclear Crisis: An Assessment." Summer 2013. pp. 67-76.

Barany, Zoltan. "Revolt and Resilience in the Arab Kingdoms." Summer 2013. pp. 89-102.

Benson, Kevin C. "A War Examined: Operation Iraqi Freedom 2003.” Winter 2013-14. pp. 119-24.

Bolan, Christopher J. “The Iranian Nuclear Debate: More Myths Than Facts.” Summer 2013. pp. 77-88.

Brooks, David C. "Cutting Losses: Ending Limited Interventions." Autumn 2013. pp. 99-110.

Bunker, Robert J. “Defeating Violent Nonstate Actors.” Winter 2013-14. pp. 57-66.

Cilluffo, Frank J. and Joseph R. Clark. "Repurposing Cyber Command.” Winter 2013-14. pp. 111-18.

Crane, Conrad C. "Special Commentary: The Lure of Strike." Summer 2013. pp. 5-12.

Deni, John R. "Strategic Landpower in the Indo-Asia-Pacific." Autumn 2013. pp. 77-86.

Dowd, Alan W. "Drone Wars: Risks and Warnings." Winter-Spring 2012-13. pp. 7-16.

Egnell, Robert. “Gender Perspectives and Fighting.” Summer 2013. pp. 33-42.

Feldman, Robert L. and Michel Ben Arrous. "Confronting Africa's Sobels." Winter 2013-14. pp. 67-76.

Field, Kimberly, James Learmont, and Jason Charland. "Regionally Aligned Forces: Business Not as Usual.” Autumn 2013. pp. 55-64.

Fivecoat, David G. "Special Commentary: American Landpower and Modern US Generalship.” Winter-Spring 2012-13. pp. 69-78.

Goodby, James E. and Ken Weisbrode. "Returning US Diplomacy." Winter 2013-14. pp. 27-34.

Greentree, Todd R. “A War Examined: Afghanistan.” Autumn 2013. pp. 87-98.

Haring, Ellen L. “What Women Bring to the Fight.” Summer 2013. pp. 27-32.

Hazelton, Jacqueline L. "Drones: What Are They Good For?" Winter-Spring 2012-13. pp. 29-34. 
Hickey, Dennis V. “Imbalance in the Taiwan Strait.” Autumn 2013. pp. 43-54.

Hoffman, Francis G. "Special Commentary: Landpower and the QDR.” Winter 2013-14. pp. 7-14.

Hooker, Richard D. “The Strange Voyage': A Short Précis on Strategy.” Winter-Spring 2012-13. pp. 59-68.

Katz, David J. “Waging Financial War.” Winter 2013-14. pp. 77-86.

Kennedy, Greg. "Drones: Legitimacy and Anti-Americanism." Winter-Spring 2012-13. pp. 25-28.

King, Anthony C. “The Female Soldier.” Summer 2013. pp. 13-26.

Mastroianni, George R. "Looking Back: Understanding Abu Ghraib." Summer 2013. pp. 53-66.

Scheipers, Sibylle. "Is the Law of Armed Conflict Outdated?”Winter 2013-14. pp. 45-56.

Simons, Anna. “Rebalancing US Military Power.” Winter 2013-14. pp. 35-44.

Sorenson, David S. “US Options in Syria.” Autumn 2013. pp. 5-16.

Strachan, Hew. "British National Strategy: Who Does It?" Summer 2013. pp. 43-52.

Tata, Samir. "Recalibrating American Grand Strategy: Softening US Policies Toward Iran in Order to Contain China." Winter-Spring 2012-13. pp. 47-58.

Terrill, W. Andrew. "Drones over Yemen: Weighing Military Benefits and Political Costs." Winter-Spring 2012-13. pp. 17-24.

Terrill, W. Andrew. "Strategic Landpower and the Arabian Gulf." Autumn 2013. pp. 65-76.

Thayer, Bradley A. and Thomas M. Skypek. "Reaffirming the Utility of Nuclear Weapons.” Winter-Spring 2012-13. pp. 41-46.

Weitz, Richard W. “Transition in Afghanistan.” Autumn 2013. pp. 29-42.

Wilson, Isaiah. “The Tragedy of American Power.” Winter 2013-14. pp 15-26.

Wilson, Ward. "Rethinking the Utility of Nuclear Weapons." Winter-Spring 2012-13. pp. 35-40.

Winton, Douglas W. "Economic Statecraft: China in Africa." Winter 2013-14. pp. 99-110.

Zarate, Juan. “The Risks of Financial War.” Winter 2013-14. pp. 87-99. 


\section{Contributor's Guidelines}

\section{Article Submissions}

The editor welcomes unsolicited works that adhere to the following criteria:

Content Requirements

Scope: The manuscript addresses strategic issues regarding the theory and practice of land warfare. Visit our website (www.strategicstudiesinstitute.army.mil/pubs/parameters/) to gain a better understanding of our current editorial scope.

Audience: US Army War College graduates and other senior military officers as well as members of government and academia concerned with national security affairs.

Clearance: If you are a member of the US military or a civilian employee of the Department of Defense or one of its service departments, your manuscript may require official clearance (see AR 360-1, ch. 6). Contact your local Public Affairs Office for assistance.

Concurrent The manuscript is not under consideration with other publishers Submissions: and has not been published elsewhere, including on the Internet.

Formatting Requirements

Length: $\quad 4,000$ words or less.

File Type $\boldsymbol{\&} \quad$ MS Word Document (.doc) or Rich Text Format (.rtf) file; Times Layout: New Roman, 12-point font; double-spaced; 1-inch margins.

Visual Aids: Only include charts, graphs, and photgraphs when they are essential to clarify or amplify the text. Images must be grayscale, a minimum of $640 \times 480$ pixels, and submitted in their original file format (.tiff or .jpg). It is not sufficient to submit images embedded in a .doc or .rtf file.

Citations: Document sources as footnotes. Indicate all quoted material by quotation marks or indentation. Reduce the number of footnotes to the minimum consistent with honest acknowledgement of indebtedness, consolidating notes where possible. Lengthy explanatory footnotes are discouraged and will be edited. The Quarterly generally uses the conventions prescribed in the Chicago Manual of Style.

Submission Requirements

Submit to: usarmy.carlisle.awc.mbx.parameters@mail.mil

Include:

- Each author's full name, mailing address, phone number, e-mail address, and curriculum vitae or biographical sketch. (When there are multiple authors, please identify the primary point of contact.)

- All original files (.doc or .rtf, and any .tiff or .jpg files if applicable) as attachments.

- An abstract.

Lead Times: If you would like your manuscript considered for a specific issue, submit it by the following dates:

- 1 December-Spring

- 1 March-Summer

- 1 June-Autumn

- 1 September-Winter

Note: Lead times only ensure the editor will consider a manuscript for publication in a specific issue; however, the editor reserves the right to recommend a manuscript for publication in any upcoming issue to meet space or topic requirements.

Review Upon receipt, we will send you a confirmation e-mail. The review Process: $\quad$ process can take four to six weeks from date of receipt. 


\section{Book Review Submissions}

Parameters publishes reviews of books on history, political science, military strategy, grand strategy, and defense studies. The editor welcomes inquiries for potential book reviews.

Send inquiries about a book or to request a review copy for a specific title to usarmy.carlisle.awc.mbx.parameters@mail.mil. In the e-mail, provide:

- The book's title and the name of the author(s) or editor(s).

- Your qualifications, full name, e-mail address, phone number, and mailing address. 


\section{The US Army War College}

The US Army War College educates and develops leaders for service at the strategic level while advancing knowledge in the global application of landpower.

The purpose of the US Army War College at this time in our nation's history is to produce graduates who are skilled critical thinkers and complex problem solvers in the global application of landpower. Concurrently, it is our duty to the Army to also act as a "think factory" for commanders and civilian leaders at the strategic level worldwide and routinely engage in discourse and debate on ground forces' role in achieving national security objectives.

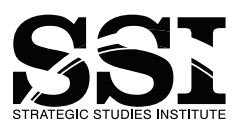

The Strategic Studies Institute publishes national security and strategic research and analysis to influence policy debate and bridge the gap between military and academia.

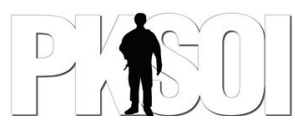

The Peacekeeping and Stability Operations Institute provides subject matter expertise, technical review, and writing expertise to agencies that develop stability operations concepts and doctrines.

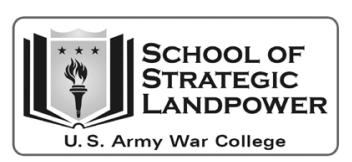

The School of Strategic Landpower develops strategic leaders by providing a strong foundation of wisdom grounded in mastery of the profession of arms, and by serving as a crucible for educating future leaders in the analysis, evaluation, and refinement of professional expertise in war, strategy, operations, national security, resource management, and responsible command.

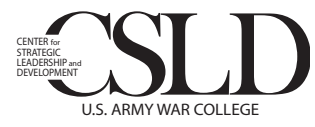

The Center for Strategic Leadership and Development contributes to the education of world class senior leaders, develops expert knowledge, and provides solutions to strategic Army issues affecting the national security community.

\section{Us Amuv war collese

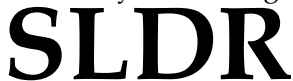

Senior Leader Development and Resiliency

The Senior Leader Development and Resiliency program supports the US Army War College's lines of effort to educate strategic leaders and provide well-being education and support by developing self-awareness through leader feedback and leader resiliency.

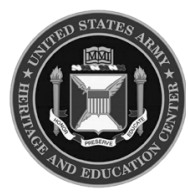

The US Army Heritage and Education Center acquires, conserves, and exhibits historical materials for use to support the US Army, educate an international audience, and honor soldiers-past and present. 
PARAMETERS (USPS 869)

US Army War College

ATTN: Parameters

47 Ashburn Drive

Carlisle, PA 17013-5010

Periodicals Postage Paid

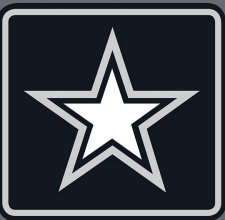

\section{U.S.ABMY}

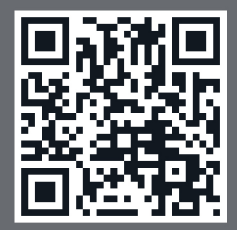

The US Army War College
THE

UNITED STATES ARMY WAR COLLEGE

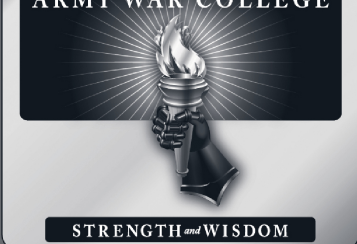

FOR THIS AND OTHER PUBLICATIONS, VISIT US AT http://www.carlisle.army.mil/ 